\title{
The Federal Democratic Republic of Ethiopia: Poverty Reduction Strategy Paper Annual Progress Report
}

Poverty Reduction Strategy Papers (PRSPs) are prepared by member countries in broad consultation with stakeholders and development partners, including the staffs of the World Bank and the IMF. Updated every three years with annual progress reports, they describe the country's macroeconomic, structural, and social policies in support of growth and poverty reduction, as well as associated external financing needs and major sources of financing. This country document for The Federal Democratic Republic of Ethiopia, dated December 2003, is being made available on the IMF website by agreement with the member country as a service to users of the IMF website.

To assist the IMF in evaluating the publication policy, reader comments are invited and may be sent by e-mail to publicationpolicy@imf.org.

Copies of this report are available to the public from

International Monetary Fund • Publication Services

$70019^{\text {th }}$ Street, N.W. $\bullet$ Washington, D.C. 20431

Telephone: (202) 623-7430 • Telefax: (202) 623-7201

E-mail: publications@imf.org • Internet: http://www.imf.org

Price: $\$ 15.00$ a copy

\section{International Monetary Fund}

Washington, D.C. 



\section{Ethiopia: Sustainable Development and Poverty Reduction Program (SDPRP)}

\section{Annual Progress Report}

(2002/03)

Ministry of Finance and Economic Development

(MOFED)

December 2003

Addis Ababa 


\section{Table of Contents}

I. INTRODUCTION.

12 Purpose of the Annual Progress Report

II. MAJOR HIGHLIGHTS OF PERFORMANCE OF SDPRP AGAINST SET TARGETS...

III. REVIEW OF SOCIO-ECONOMIC CONDITIONS IN ETHIOPIA DURING THE 2002/03 FISCAL

YEAR

3.1 Recent Macroeconomic Developments.

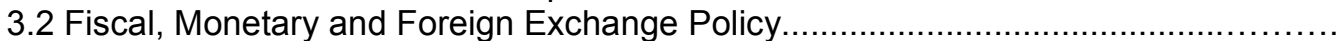

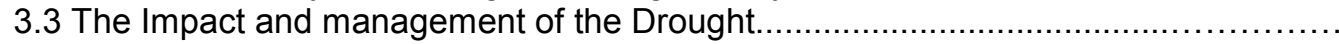

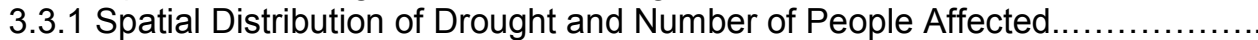

3.3.2 Long-term Response to Drought

3.4 Assessment of Poverty Status

3.4.1. Growth and Poverty................................................

3.4.2 Social Impact of the Introduction of the Value Added Tax (VAT)..................

3.4.3 The Impact of Continuous Decline in International coffee prices.....................

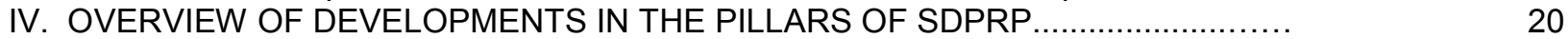

4.1 Agricultural Development Lead Industrialization (ADLI) Strategy...................

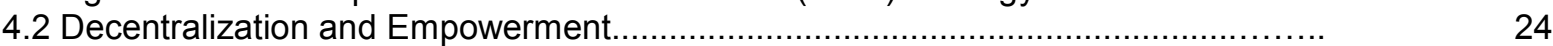

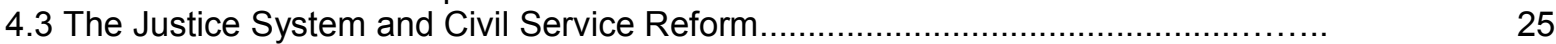

4.3.1 The Justice System Reform Program.....................................................

4.3.2 Civil Service Reform........................................................................

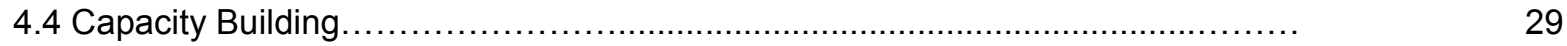

V. MACROECONOMIC AND STRUCTURAL REFORMS ..................................... 33

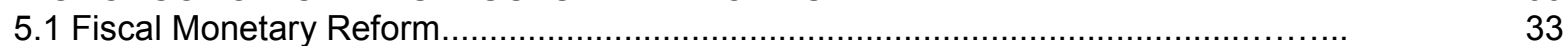

5.1.1 Expenditure Policy and Management....................................................

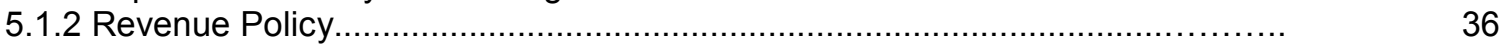

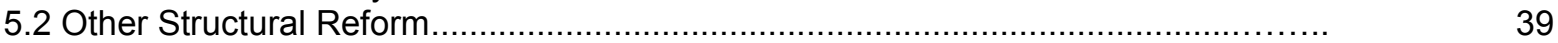

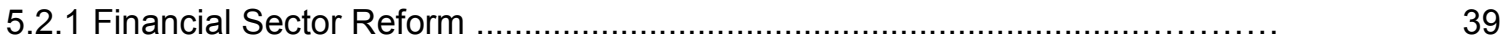

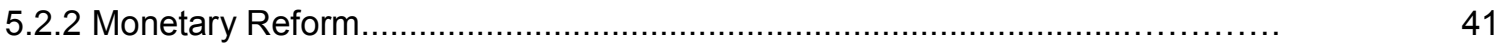

VI. FINANCING THE SDPRP AND THE MACROECONOMIC FISCAL FRAMEWORK

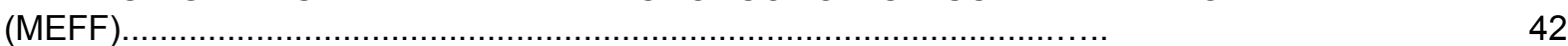

6.1 Out-turn During the First Year of the SDPRP Implementation $(2002 / 03)$................

6.1.1 Fiscal Outturn During 2002/03 Versus the 2002/03 Budget....................

6.1 .1 .1 Revenue............................................................

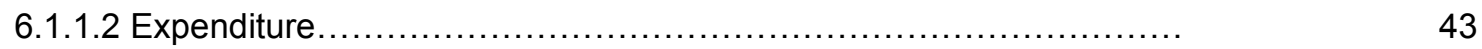

6.2 Update on the 2003/04-2005/06 Macroeconomic Fiscal Framework (MEFF).........

6.2.1 Alternative Macro Scenario. ............................................... 45

6.2.1.1 Real Sector and Prices..............................................

6.2.1.2 Fiscal Implication of Alternative Macro Scenarios $\quad 47$

6.2.1.3 Implication of Alternative Scenarios on SDPRP Financing ................. 53

6.2.2 The 2003/04 Budget..................................................

6.3 Update on the SDPRP program costs for core Poverty-oriented sectors..............

6.4 Managing the Gap Between Program Cost and Available............................ 57

VII. OVERVIEW PERFORMANCES OF KEY POVERTY-ORIENTED SECTOR

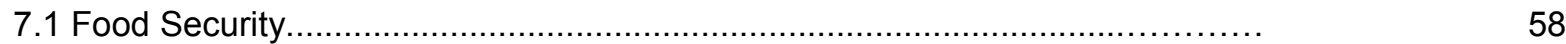

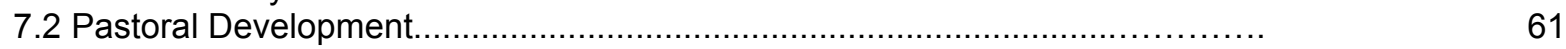

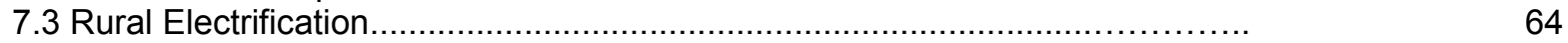

7.4 Rural Telecommunication Service Expansion........................................

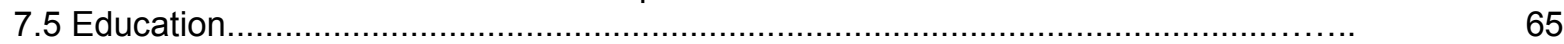

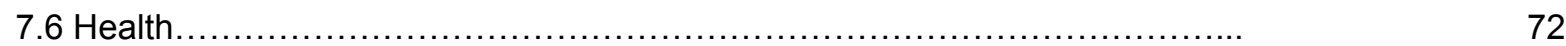

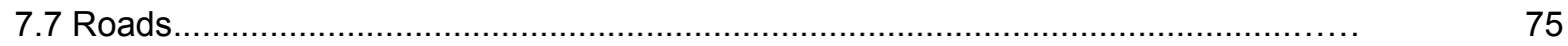

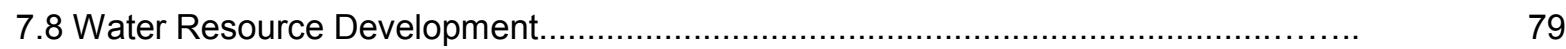

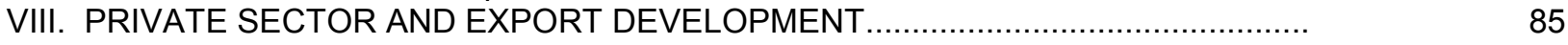




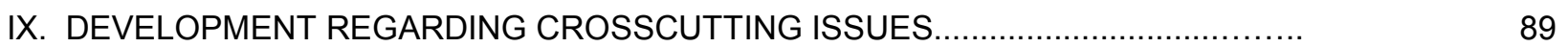

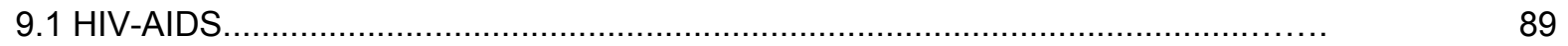

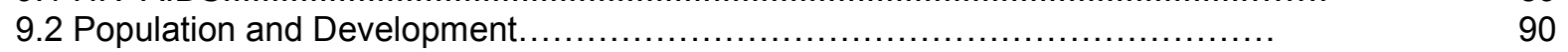

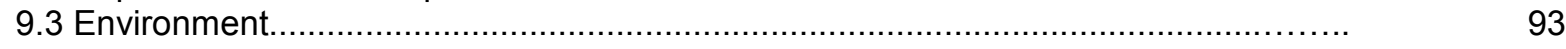

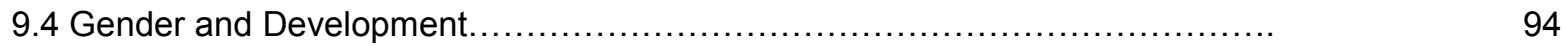

X. OVERVIEW OF EXTERNAL ECONOMIC ENVIRONMENT FOR SDPRP

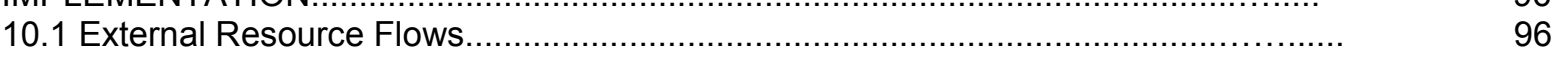

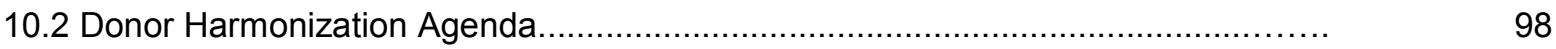

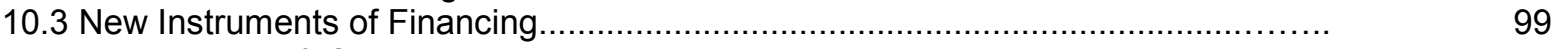

10.4 Debt strategy \& Sustainability Analysis ....................................

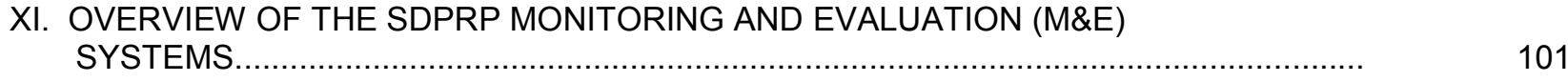

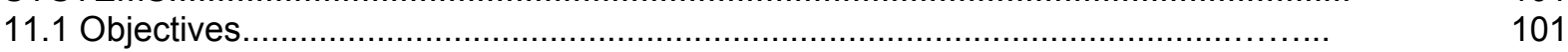

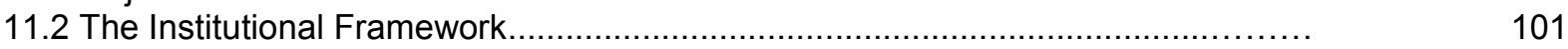

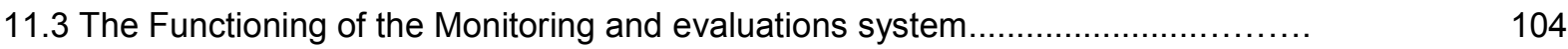

11.4 Costing Implementation of SDPRP Monitoring and Evaluation System.............. 106

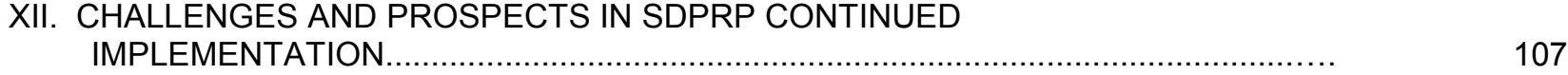

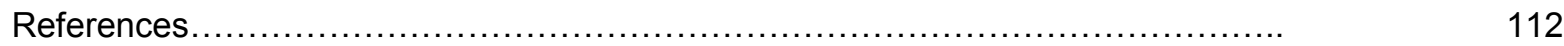




\section{List of Tables}

1. Table 1: Trends in Macroeconomic Indicators for FYs 1999/ 2000-2002/03

Values in Million Birr and \% Otherwise ......................................................... 10

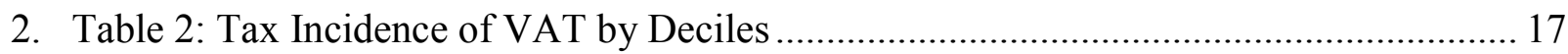

3. Table 3: Distribution of Water Harvesting structures ........................................................... 24

4. Table 4 Comparison of 2002/03 Fiscal out turn with the Budget Million Birr ------------ 44

5. Table 5 Public Expenditure on Poverty Oriented Sectors as a ratio of Total Public Expenditure --- Expence 46

6. Table 6: Real Sector Projections under Law, Base line and High case Scenario ---------- 47

7. Table 7: Summary of Government Finance Forecast: Low, Baseline and High Scenarios

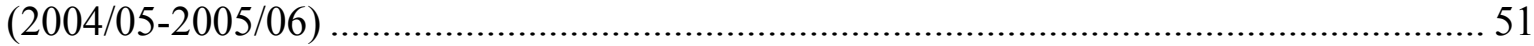

8. Table 8: Sectoral Distribution of Poverty Targeted Expenditure in 2003/04 Budget Values in Million Birr ------------------on

9. Table 9: Updates on SDPRP Program Costs Based on Sectoral Requirements ................. 57

10. Table 10: Trends in Public Spending on Agriculture \& Food Security, Value in

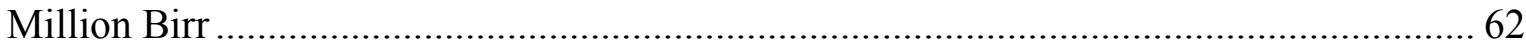

11. Table 11: Targets and Performance in 2002/03 ............................................................. 71

12. Table 12: Trends in Public Spending on Education \& Training Value in Million Birr....... 72

13. Table 13: Trends in Public Spending on Health, Value in Million Birr .............................. 76

14. Table 14: Trends in Public Spending on Roads, Value in Million Birr............................... 77

15. Table 15: Access to Water Supply in Rural and Urban Areas (\%)..................................... 83

16. Table 16: Trends in Public Spending on Water, Value in Million Birr .............................. 85

17. Table 17: Disbursement Comparison by major Donors In millions of USD ........................ 98

\section{List of Matrix Tables}

Matrix Table 1: SDPRP Targets and outturns for the First Year (2002/03) ------------------ 5

Matrix Table 2: SDPRP HIPC Quantitative and Qualitative Triggers and Outcomes ------- 7

\section{List of Annexes}

Annex 1: SDPRP Policy Matrix: Goals, Outcomes, Outputs, and Policy Measures/Actions, 2002/03-2004/05

Annex 2: List of Urban Centers Selected for Urban Management Reform by Region

Annex 3: List of welfare Related Survey and Censuses to be conducted by the Central Statistics

Authority During the Upcoming Years

\section{List of Acronyms}




\section{Introduction}

\subsection{Background to the Annual Progress Report}

In 2002 the Ethiopian Government committed itself to the Sustainable Development and Poverty Reduction Programme (SDPRP). This is the first annual progress report on the implementation of the program. The fundamental development objectives of the Federal Democratic Republic of Ethiopia (FDRE) set out in the SDPRP were to build a free-market economic system in the country, which will enable the economy to develop rapidly, to end dependence on food aid; and to allow poor people to benefit from economic growth.

The development strategy was built on four pillars:

a) Agricultural Development Led Industrialization (ADLI),

b) Reform of the Justice System and the Civil Service

c) Decentralization and empowerment, and

d) Capacity building in public and private sectors.

The main thrusts of the SDPRP are:

$>$ Concentration on agriculture, which is the source of livelihood for $85 \%$ of the population and the bulk of the poor. Agriculture is a potential source of surplus to fuel the growth of other sectors of the economy;

$>$ Strengthening private sector growth especially in industry, to promote offfarm employment and output growth, supported by public investment in necessary infrastructure;

$>$ Rapid export growth, including high value agricultural products and export oriented manufacturing sectors (particularly intensified processing of high quality skins/leather and textile garments);

$>$ Investment in education and enhanced efforts to build capacity to overcome critical constraints to the implementation of development programs;

$>$ Deepening decentralization to shift decision-making closer to the grass-roots, to improve accountability, responsiveness and service delivery;

$>$ Improvements in governance to empower the poor \& establish an appropriate framework for private sector growth and development;

$>$ A strong focus on agricultural research, and water harvesting, small scale irrigation and

$>$ Increased water resource utilization to ensure food security.

The overarching objective the government has set itself is to reduce poverty at the same time as maintaining macroeconomic stability. Government committed itself to working towards meeting the Millennium Development Goals (MDGs) of 2015. This requires real growth of 5.7\% per annum until 2015 to reduce poverty by half from its current level.

Measures to improve institutions, such as the reform of the legal system, enforcing contracts, ensuring property rights, maintaining peace and stability, and improving the functioning of public services were seen as making an important contribution to growth and equity. Programs 
have already been initiated on capacity building, devolution and empowerment, justice system and civil service reform, anti-corruption, etc.

The FDRE remains committed to the SDPRP and is concentrating its energies on implementing it. Because this is a report on the first year of implementation, it is too early to judge the end results of the program in terms of its impact on poverty. Therefore this report is mainly concerned with the mobilization of inputs to implement the program, detailing progress made in key sectors, but also highlighting constraints.

The government was encouraged by the reception given to the SDPRP at the 2002 Consultative Group meeting, and the commitments to support the program received from the donor and NGO communities. However, the main responsibility for implementing the SDPRP lies with the FDRE government, accountable to the Ethiopian people. Nevertheless, faced with complex and deep poverty situation the government recognizes that it requires increasing levels of assistance to achieve its development goals.

\subsection{Purpose of the Annual Progress Report}

The Annual Progress Report has two main purposes:

1) It is a tool for coordinating the implementation of the SDPRP. The SDPRP is intended to mobilize efforts in all sectors and at many levels of government, and involves far reaching innovations in the system of government. To establish the required momentum, a comprehensive internal review process has been instituted, to record progress, to identify bottlenecks and lagging sectors and to accelerate the implementation of the program where required.

2) The APR is intended to provide the basis for continuing dialogue with the donor community as well as private sector and NGO community regarding progress with the SDPRP, ongoing financing requirements and tackling constraints, where joint action is required.

This report records progress where it has occurred, identifies areas where progress is lagging, and explores opportunities and challenges in SDPRP Continued implementation. Inevitably, in a comprehensive program, involving deep reforms in a number of fronts, there are variations in the speed of implementation. The most profound challenges relate to the efforts to accelerate program implementation in the context of a thoroughgoing decentralization of decision-making and control to the local level. The need to strengthen capacity, particularly at the woreda level, runs through the report, affecting all sectors.

Implementation of the program involves concrete tasks of raising the rate of development spending, including working with development partners to harmonize aid modalities, to relax constraints on aid utilization and improve absorptive capacity. Significant progress has been made in joint work with the donor community of harmonization issues, but reports on implementation indicate that difficulties have still to be overcome for the available assistance to be absorbed efficiently. Discussion of the APR should provide an opportunity to extend progress with harmonization and easing aid implementation bottlenecks.

Perhaps the greatest challenge in implementing the SDPRP relates to institutional innovations. In some areas of work, there is a complex process of "learning by doing", involving the 
development of new government procedures and, perhaps most profoundly, new approaches to responsibility and accountability in decision-making. Capacity building in the public service also involves a complex range of tasks, including training, the improvement of incentive systems and the building of a stronger commitment to service.

In relation to the private sector, the government has committed itself to increasing its role and steadily improving the policy environment. Significant first steps have been made and government is committed to maintain momentum in its policy reforms and reinforcing among others the Public-Private Partnership (PPP).

In dialogue with the donor community, within the context of broad agreement about the broad goals and policies set out in the SDPRP, it will be appropriate to examine the next steps in implementation, including actions now required by both sides of the partnership to accelerate momentum.

With respect to the participatory process, broad discussions on strategy, policy and implementation issues have been held during the year on important areas of SDPRP. Industrial development strategy was discussed with the private sector and trade unions. This is key complementary strategy to ADLI - with its focus on rural transport Extensive discussions were held with the business community before the introduction of the new income tax and VAT Proclamations. Discussion on Youth Policy was also extensive especially with the youth. The New Coalition for Livelihood \& Food Security for Ethiopia was very much an outcome of broad-based multi-stakeholder discussion. Multi-stake holder conference was also held on the significance of leadership in HIV/AIDS control and prevention. Broad based discussions were held at the National Population Conference organized to mark the tenth anniversary of the issuance of National Population Policy (April 1993). A draft Diagnostic Trade Integration Study (DTIS) has been completed and a conference was held in November 2003 to provide forum for different stakeholders, both government and non-state actors to review the findings and recommendations in the DTIS, which included technical assistance action plans.

The preparation of the SDPRP Annual Progress Review (APR) benefited from the dialogue with different stakeholders. The APR working draft was circulated to the donor community in Ethiopia, to the private sector and NGO community. Discussions were held to share perspectives. The APR was also presented and discussed at the Partnership Event for Livelihood \& Food Security for Ethiopia held during December 1-2, 2003. 


\section{Major Highlights of Performance of SDPRP Against Set Targets}

The fiscal year 2002/03 was difficult year mainly owing to the drought, which affected about 13 million people across the country. Real GDP declined by $3.8 \%$ during $2002 / 03$. The projected GDP growth rate for FY 2002/03 was 6\%. Overall agricultural value added declined by $12 \%$ owing to an about $25 \%$ drop in major crops (cereal, pulses and oilseeds) production. These crops accounted on average for about $60 \%$ of overall agricultural value added. Mostly triggered by shortfalls in agricultural production, inflation as measured by the consumer price index (CPI) surged to about 15 percent by the end of the 2002/03 Fiscal Year.

Overall, the negative growth in F.Y 2002/03, the drought affecting 13 million people and the continued world coffee price collapse are major negative factors that seriously affected people's livelihoods and the efforts being made to enhance growth and poverty reduction in Ethiopia.

Notwithstanding these adverse circumstances, a number of achievements have been recorded in key areas. Matrix Table 1 below describes achievements for the year under review (2002/03) for key poverty-oriented sectors against the indicative and performance targets for the SDPRP period (2002/03-2004/05) as indicated in Table 13.1 and 13.2 of Chapter XI of the SDPRP,

Moreover SDPRP period targets were refined and translated in to annual targets and actions called SDPRP matrix. The goals, outcomes outputs, and the progress to date for 2002/03 and planned actions for 2003/04-2004/05 is presented in the Matrix. This is included as attachment to the APR (Annex 1). In addition, the status of HIPC triggers is shown as Matrix Table 2, which shows that targets are met. 
Matrix Table 1: SDPRP Targets and Outturns for the First Year (2002/03)

\begin{tabular}{|c|c|c|c|c|}
\hline Sector & Indicator & $\begin{array}{c}\text { Target for } \\
\text { SDPRP Period } \\
(2002 / 03-2004 / 05)\end{array}$ & $\begin{array}{l}\text { Achievement } \\
\text { By end } \\
2002 / 03\end{array}$ & Remarks \\
\hline Poverty and Inequality & Poverty Head Count (Po) & $\mathrm{Po}=40$ by end of $2004 / 05$ & & \\
\hline \multirow[t]{6}{*}{$\begin{array}{l}\text { Agriculture \& } \\
\text { Food Security }\end{array}$} & $\begin{array}{l}\text { Number of farming households } \\
\text { covered by extension }\end{array}$ & $\begin{array}{l}6 \text { million by end of the } \\
\text { SDPRP Period }(2004 / 05)\end{array}$ & 4.1 million & \\
\hline & $\begin{array}{l}\text { Number of trainees in Agriculture } \\
\text { TVET }\end{array}$ & $\begin{array}{l}39,797 \text { by end of the } \\
\text { SDPRP period }(2004 / 05)\end{array}$ & 25,928 & $\begin{array}{l}\text { By the end of the } \\
\text { program period a } \\
\text { total of about } \\
431,717 \text { Das and } \\
\text { middle level } \\
\text { farmers will be } \\
\text { trained }\end{array}$ \\
\hline & $\begin{array}{l}\text { Number of trainees in Farmers' } \\
\text { Training Centers (FTCs) }\end{array}$ & $\begin{array}{l}391,920 \text { by end of the } \\
\text { SDPRP Period }(2004 / 05)\end{array}$ & & \\
\hline & Quantity of Fertilizer Consumption & $\begin{array}{l}1,089,000 \text { by end of } \\
\text { SDPRP Period }(2004 / 05)\end{array}$ & $277,000 \mathrm{MT}$ & \\
\hline & Quantity of Improved Seed Sales & $\begin{array}{l}710,000 \text { Quintals by end of } \\
\text { SDPRP Period }(2004 / 05)\end{array}$ & $\begin{array}{l}159,220 \\
\text { Quintals }\end{array}$ & \\
\hline & $\begin{array}{l}\text { Number of cooperatives } \\
\text { restructured and newly established }\end{array}$ & $\begin{array}{l}1639 \text { by end of SDPRP } \\
\text { Period }(2004 / 05)\end{array}$ & $\begin{array}{l}817 \\
\text { agricultural } \\
\text { cooperatives } \\
\text { restructured } \\
\text { and/or newly } \\
\text { established }\end{array}$ & \\
\hline \multirow[t]{10}{*}{ Education } & Gross Primary Enrollment & $\begin{array}{l}65 \text { percent by end of } \\
2004 / 05\end{array}$ & $\begin{array}{l}\text { Total } 64.4 \\
\text { percent }\end{array}$ & \\
\hline & Average Grade 4-8 Repetition Rate & $\begin{array}{l}6.4 \text { percent by end of } \\
2004 / 05\end{array}$ & & \\
\hline & Girls/Boys Ratio & $\begin{array}{l}45 \text { percent by end of } \\
2004 / 05\end{array}$ & 41.2 percent & \\
\hline & Primary School Drop out Rate & $\begin{array}{l}8.9 \text { percent by end of } \\
2004 / 05\end{array}$ & & \\
\hline & $\begin{array}{l}\text { Education Budget Share as } \\
\text { Percent of total Expenditure (\%) }\end{array}$ & $\begin{array}{l}19 \text { percent by end of } \\
2004 / 05\end{array}$ & 17.2 percent & \\
\hline & Grade 5 Completion Rate & 34 percent for $2002 / 03$ & 34 percent & \\
\hline & $\begin{array}{l}\text { Gender Parity Index (GPI) for } \\
\text { grade 1-8 }\end{array}$ & 0.72 for $2002 / 03$ & 0.72 & \\
\hline & $\begin{array}{l}\text { Text Book/Pupil ratio for core } \\
\text { subject for grade 1-8. }\end{array}$ & $1: 2$ for $2002 / 03$ & $1: 2$ & \\
\hline & Pupil to Teacher ratio $(1-8)$ & 64 for $2002 / 03$ & 64 & \\
\hline & Pupil to Section Ratio Primary & & 73 & \\
\hline \multirow[t]{4}{*}{ Health } & $\begin{array}{l}\text { Infant Mortality Rate (Deaths per } \\
1000 \text { ) }\end{array}$ & $85 / 1000$ by end of $2004 / 05$ & & $\begin{array}{l}\text { Data } \\
\text { annually } \\
\text { available }\end{array}$ \\
\hline & $\begin{array}{l}\text { Under } 5 \text { Child Mortality } \text { Rate } \\
\text { (Deaths per 1000) }\end{array}$ & $\begin{array}{l}160 / 1000 \text { by end of } \\
2004 / 05\end{array}$ & & " \\
\hline & $\begin{array}{l}\text { Maternal Mortality Rate } \\
\text { (Deaths per } 100,000)\end{array}$ & $400-450$ by end of $2004 / 05$ & & " \\
\hline & Access to Health Services (\%) & $\begin{array}{l}65 \text { percent by end of } \\
2004 / 05\end{array}$ & 60 percent & \\
\hline
\end{tabular}




\begin{tabular}{|c|c|c|c|c|}
\hline & $\begin{array}{l}\text { Health Budget Share as Percent of } \\
\text { total Expenditure (\%) }\end{array}$ & $\begin{array}{l}8.2 \text { percent by end of } \\
2004 / 05\end{array}$ & 4.6 percent & \\
\hline & Malaria Prevalence Rate & & 8.7 percent & \\
\hline & Contraceptive Prevalence Rate & & 18.7 percent & \\
\hline & $\begin{array}{lll}\begin{array}{l}\text { Doctors/Health } \\
\text { Population Ratio }\end{array} & \text { Officers } & \text { to } \\
\end{array}$ & & $1: 28,339$ & \\
\hline & Nurses to Population Ratio & & $1: 5236$ & \\
\hline & Technicians to Population Ratio & & $1: 34,614$ & \\
\hline & Sanitarians to Population Ratio & & $1: 69,228$ & \\
\hline & $\begin{array}{lll}\begin{array}{l}\text { Frontline Health } \\
\text { Population Ratio }\end{array} & \text { Worker to } \\
\end{array}$ & & $1: 569,661$ & \\
\hline & Pharmacists to Population Ratio & & & \\
\hline Water & Access to clean Water $(\%)$ & & & \\
\hline & • National & $\begin{array}{l}39.4 \text { percent by end of } \\
2004 / 05\end{array}$ & 34.1 & \\
\hline & - Urban & $\begin{array}{l}82.5 \text { percent by end of } \\
2004 / 05\end{array}$ & 85.0 & \\
\hline & - $\quad$ Rural & $\begin{array}{l}31.4 \text { percent by end of } \\
2004 / 05\end{array}$ & 25.0 & \\
\hline Roads & Road Network (Density) & $\begin{array}{l}\text { Road Density } 29 \mathrm{~km} / 1000 \\
\text { sq. km. }\end{array}$ & $\begin{array}{l}31-\mathrm{km} / 1000 \\
\text { sq. } \mathrm{km}\end{array}$ & \\
\hline HIV/AIDS & Transmission & $\begin{array}{l}\text { Reduce transmission by } 25 \\
\text { percent by end of } 2004 / 05\end{array}$ & & \\
\hline & Prevalence & $\begin{array}{l}\text { Contain prevalence at } 7.3 \\
\text { percent by end of } 2004 / 05\end{array}$ & 6.6 percent & \\
\hline
\end{tabular}


Matrix Table 2: SDPRP HIPC Quantitative \& Qualitative Triggers and Outcomes

\begin{tabular}{|c|c|c|c|}
\hline Sector & Indicator & 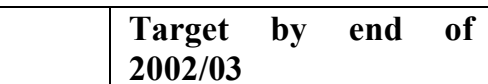 & $\begin{array}{l}\text { Achievement } \\
\text { By end 2002/03 }\end{array}$ \\
\hline \multicolumn{4}{|c|}{ Quantitative Indicators and Targets } \\
\hline \multirow[t]{3}{*}{$\begin{array}{l}\text { Agriculture \& } \\
\text { Food Security }\end{array}$} & $\begin{array}{l}\text { Proportion of extension } \\
\text { staff involvement in } \\
\text { fertilizer delivery and } \\
\text { credit administration }\end{array}$ & $\begin{array}{l}\text { Reduction in the proportion of } \\
\text { extension staff involvement } \\
\text { from } 30 \% \text { in } 2004 \text { to zero in } \\
2006\end{array}$ & $\begin{array}{l}\text { Well in progress as per the } \\
\text { time frame agreed }\end{array}$ \\
\hline & $\begin{array}{l}\text { Phasing out } \\
\text { Government fertilizeral } \\
\text { credit guarantees }\end{array}$ & $\begin{array}{l}\text { Complete phasing out of } \\
\text { Regional Government fertilizer } \\
\text { credit guarantees by } 2006\end{array}$ & $\begin{array}{l}\text { Well in progress as per the } \\
\text { time frame agreed }\end{array}$ \\
\hline & & $\begin{array}{l}\text { Training } 80 \% \text { of cooperatives' to } \\
\text { access bank credit by } 2006\end{array}$ & $\begin{array}{l}\text { Well in progress as per the } \\
\text { time frame agreed }\end{array}$ \\
\hline \multirow[t]{2}{*}{ Education } & $\begin{array}{ll}\text { Repetition Rate at } \\
\text { Primary Level }\end{array}$ & 7 percent & 6.8 percent \\
\hline & $\begin{array}{l}\text { Female Gross Primary } \\
\text { Enrolment }\end{array}$ & 50 percent & 54 percent \\
\hline \multirow[t]{2}{*}{ Health } & $\begin{array}{l}\text { DPT3 Vaccination } \\
\text { Coverage as proportion } \\
\text { of surviving infants }\end{array}$ & 50 percent & 50.4 percent \\
\hline & $\begin{array}{ll}\text { Health } & \text { Service } \\
\text { Utilization } & \end{array}$ & 30 percent & $\begin{array}{l}\text { Achieved but the indicator } \\
\text { has been slightly modified }\end{array}$ \\
\hline HIV/AIDS & $\begin{array}{lr}\text { Condom } & \text { Distribution by } \\
\text { social } & \text { marketing } \\
\text { (excluding } & \text { free } \\
\text { distribution) } & \\
\end{array}$ & 62 million & Achieved \\
\hline \multicolumn{4}{|c|}{ Process Indicators and Targets } \\
\hline SDPRP & $\begin{array}{l}\text { SDPRP completed and } \\
\text { implemented for one year }\end{array}$ & $\begin{array}{lll}\text { Annual } & \text { Progress } & \text { Review } \\
\text { Report } & & \end{array}$ & $\begin{array}{l}\text { Implemented for one year } \\
\text { and Annual Progress } \\
\text { Report prepared and } \\
\begin{array}{llr}\text { discussed with all } \\
\text { stakeholders }\end{array} \\
\end{array}$ \\
\hline Macroeconomic Stability & Implementation of PRGF & $\begin{array}{l}\text { Ensure PRGF implementation } \\
\text { is on track }\end{array}$ & $\begin{array}{l}\text { On track and well in } \\
\text { progress }\end{array}$ \\
\hline \multirow[t]{2}{*}{$\begin{array}{ll}\text { Public } & \text { Expenditure } \\
\text { Management } & \end{array}$} & $\begin{array}{l}\text { Reconciliation r of } \\
\text { Monetary and Fiscal } \\
\text { accounts }\end{array}$ & $\begin{array}{l}\text { Reconciliation of Monetary and } \\
\text { Fiscal Accounts for 2001/02 } \\
\text { and 2002/03 }\end{array}$ & $\begin{array}{l}\text { Reconciliation completed } \\
\text { for } 2001 / 02 \text { and well in } \\
\text { progress for } 2002 / 03\end{array}$ \\
\hline & $\begin{array}{l}\text { Consolidation of } \\
\text { and regional budget } \\
\text { including all extra- } \\
\text { budgetary funds }\end{array}$ & $\begin{array}{l}\text { Consolidation of federal and } \\
\text { regional budget for } 2001 / 02 \text {, } \\
2002 / 03 \text {, and } 2003 / 04 \text { including } \\
\text { all extra-budgetary funds }\end{array}$ & $\begin{array}{l}\text { Budget consolidation } \\
\text { completed for the three } \\
\text { fiscal years along with } \\
\text { notes on the history and } \\
\text { current status of the various } \\
\text { funds }\end{array}$ \\
\hline
\end{tabular}




\section{Review of Socio-economic Conditions in Ethiopia During the 2002/03}

\subsection{Recent Macroeconomic Developments}

Although Ethiopia's GDP growth rate averaged 6 percent from 1991/92 to 2000/01, this positive trend was marred by wide fluctuations as a result of numerous exogenous shocks of both domestic and external origin. Such shocks hit the poorest and most vulnerable members of society the hardest, and the negative effects on consumption and savings are enduring.

The recent drought is the most severe since 1984/85. As a result, cereal production declined by about 6 percent in 2001/02 and by a further 26 percent during 2002/03. As a result real GDP growth in 2001/02 was revised downwards to 1.2 percent from 5 percent; a sharp deceleration from the 7.7 percent growth rate recorded in 2000/01. GDP shrank by 3.8 percent in 2002/03, from projected level of $6 \%$ but a recovery projected at more than 6.7 percent is expected in $2003 / 04$ stimulated by a rise in agricultural output. Because of the drought in 2002, an estimated 13 million people needed food assistance, compared with about 4 to 5 million in need during a normal crop year. This experience has led to the development of alternative macroeconomic scenario discussed in chapter VI.

Because of the drought in 2002, an estimated 13 million people needed food assistance, compared with about 4 to 5 million in need during a normal crop year. Poorly functioning, unstable and incomplete rural markets exacerbated the drought effects. This was particularly true in the remote and drought-prone areas. Bumper crops in earlier years drove down food prices, with catastrophic effects on farmers' income. Consequently, many farmers could not repay their debt, and did not have the means to purchase and apply modern inputs to this year's crops. Supplying food aid to deficit areas through imports also acts to depress food prices. For this reason, donors have been requested to buy food from surplus regions to transfer to food-deficit regions insofar as this is possible, instead of importing food aid.

Despite the Government's prudent fiscal stance and cautious monetary policy, the average annual inflation rate, as measured by consumer prices, accelerated to 15.1 percent during fiscal year $2002 / 03$, in sharp contrast to the two previous years of falling prices, due to the decline in agricultural production.

Despite the attendant problems the emphasis on social and economic infrastructure and maintenance of macroeconomic stability was well on track during 2002/03.

On the fiscal side, spending on social and economic infrastructure sectors such as education, health, roads and agriculture and food security has also kept its momentum even under such difficult circumstances. As indicated in summary Table 1 below, spending on education as a ratio to total public expenditure reached over 16.0 percent followed by roads (10.1 percent) and agriculture and food security ( 7.5 percent) while defense spending has been scaled down from about 38.9 percent of total expenditure to about 11 percent of total expenditure by the end of 2002/03. Total poverty targeted spending reached over 15.1 percent (slightly lower than programmed owing to lags in disbursements from external assistance and loans) of GDP by the 
end of 2002/03.With regard to revenue; tax revenue averaged about 15 percent of GDP by the end of 2002/03, with only a modest 4.6 percent increase over the previous fiscal year.

On the external side, world coffee prices are still around an historic low in real terms. That, along with higher oil prices, led to a sharp fall in the terms of trade, by 33.9 percent in FY 2000/01, by another 6.3 percent in FY 00/01, and by yet another 8.9 percent (estimated) in FY 2001/02. Earnings from coffee exports, accounting for 34 percent of merchandise exports in 2002/03, fell by more than half, from USD 420 million in FY 97/98. An improvement in total export earnings has been recorded for fiscal year 2002/03(about 7 percent), largely attributable to more robust growth of non- coffee exports (over 9.8 percent) mainly consisting of meat and meat products, oil seeds, sugar, gold and chat. During the same period, the total import bill rose by 9.4 percent to reach USD 1856 million mainly driven by increases in imports of fuel, capital goods, and food.

The external current account deficit, including official transfers declined from 5.7 percent of GDP in 2001/02 to 4.7 percent of GDP in 2002/03 where as excluding official transfers, the deficit remained at 12.1 percent. The gross official reserves rose to USD 929.4 million, enough to cover 4.5 months of imports.

Despite the Government's prudent fiscal stance and cautious monetary policy, the average annual inflation rate, as measured by consumer prices, accelerated to 15.1 percent during fiscal year 2002/03, in sharp contrast to the two previous years of falling prices, due to the decline in agricultural production.

Summary Table 1 below describes trends in major macroeconomic indicators in recent years ending in 2002/03 Fiscal Year. 
Table 1: Trends in Macroeconomic Indicators for FYs 1999/ 2000-2002/03

\begin{tabular}{|c|c|c|c|c|}
\hline Item & $1999 / 00$ & $2000 / 01$ & $2001 / 02$ & $2002 / 03^{1}$ \\
\hline \multicolumn{5}{|l|}{$\begin{array}{l}\text { Real Sector \& Prices } \\
\text { (Percentage change over previous year) }\end{array}$} \\
\hline$\bullet \quad$ Real GDP & 5.4 & 7.7 & 1.2 & -3.8 \\
\hline - $\quad$ Agricultural Value Added & 2.2 & 11.5 & -3.1 & -12.2 \\
\hline - $\quad$ Non-Ag. Production & 7.9 & 4.8 & 4.8 & 2.6 \\
\hline - $\quad$ Services & 9.5 & 4.7 & 4.6 & 2.0 \\
\hline - Consumer prices inflation & 4.2 & -5.2 & -7.2 & 15.1 \\
\hline \multicolumn{5}{|l|}{ Trends in Macroeconomic Indicators } \\
\hline $\begin{array}{llll}- & \begin{array}{l}\text { Total Agriculture and Food Security } \\
\text { spending as \% of GDP }\end{array} & \\
\end{array}$ & 2.7 & 3.0 & 3.4 & 3.3 \\
\hline - $\quad$ Total Education Expenditure as \% of GDP & 3.2 & 4.2 & 4.7 & 5.6 \\
\hline - $\quad$ Total Health Expenditure as \% of GDP & 1.0 & 1.8 & 1.9 & 1.6 \\
\hline - $\quad$ Total Road Expenditure as \% of GDP & 2.1 & 2.9 & 37 & 3.3 \\
\hline - $\quad$ Defense Expenditure as \% of GDP & 13.1 & 6.1 & 5.0 & 4.1 \\
\hline $\begin{array}{l}\text { - Total Education Expenditure as \% of } \\
\text { Total Expenditure }\end{array}$ & 9.3 & 14.2 & 13.9 & 16.0 \\
\hline $\begin{array}{ll}- & \text { Total Health Expenditure as \% of Total } \\
\text { Expenditure }\end{array}$ & 3.2 & 6.4 & 5.7 & 4.9 \\
\hline $\begin{array}{l}\text { - Total Road Expenditure as \% of Total } \\
\text { Expenditure }\end{array}$ & 6.2 & 10.2 & 11.0 & 10.1 \\
\hline $\begin{array}{ll}\text { Total Agriculture and Food Security } \\
\text { spending as \% of Total Expenditure }\end{array}$ & 8.0 & 10.3 & 8.6 & 7.5 \\
\hline $\begin{array}{llllll}- & \text { Defense Expenditure as } \% \text { of Total } \\
& \text { Expenditure }\end{array}$ & 38.9 & 21.5 & 14.8 & 11.4 \\
\hline \multicolumn{5}{|l|}{ Financial Balances (Percentage of GDP) } \\
\hline • $\quad$ Gross Domestic Saving & 0.9 & 3.1 & 2.5 & 1.8 \\
\hline - Gross Domestic Investment & 15.9 & 17.8 & 20.5 & 21.1 \\
\hline - $\quad$ Resource Gap & -15.0 & -14.7 & -18.0 & -19.4 \\
\hline - $\quad$ External Current Account $^{2}$ & -5.1 & -3.6 & -5.7 & -4.7 \\
\hline \multicolumn{5}{|l|}{ Government Finance (\% of GDP) } \\
\hline$\bullet \quad$ Domestic Revenue & 18.4 & 18.8 & 20.1 & 19.6 \\
\hline O/w: Tax Revenue & 11.5 & 13.7 & 15.3 & 14.5 \\
\hline - $\quad$ External grants & 2.9 & 4.8 & 4.7 & 5.3 \\
\hline - $\quad$ Total expenditure ${ }^{3}$ & 33.0 & 28.4 & 32.2 & 34.8 \\
\hline $\mathrm{O} / \mathrm{w}:$ poverty related & 8.8 & 11.8 & 14.6 & 15.1 \\
\hline Overall balance (incl. grants) & -11.7 & -5.5 & -9.3 & -8.4 \\
\hline \multicolumn{5}{|l|}{$\begin{array}{l}\text { External Sector } \\
\text { (US\$ million) }\end{array}$} \\
\hline Exports & 486.1 & 462.7 & 452 & 483 \\
\hline Imports & 1611 & 1556 & 1696 & 1940 \\
\hline Debt Service to Export Ratio $(\%)^{4}$ & 56.3 & 43.5 & 30.5 & 32.4 \\
\hline GDP@CMP & 53189.8 & 54210.7 & 51760.7 & 56,958 \\
\hline \multicolumn{5}{|c|}{$\begin{array}{l}\text { Source: Ministry of Finance and Economic Development } \\
\text { * Excluding Special Program }\end{array}$} \\
\hline \multicolumn{5}{|l|}{${ }^{1}$ Provisional } \\
\hline \multicolumn{5}{|l|}{${ }^{2}$ Including official transfers } \\
\hline \multicolumn{5}{|l|}{${ }^{3}$ Excluding special programs } \\
\hline
\end{tabular}


However, annual average core inflation was 3 percent. The average saving deposit interest rate in fiscal year 2002/03 is unchanged from the previous year at 3 percent and the average lending rate also is unchanged at 7.5 percent. The broad money supply (M2) increased by 10.4 percent during fiscal year 2002/03 to reach Birr 30.1 billion, driven mainly by a 41.2 percent rise in net foreign assets (NFA) and a much more modest 2.6 percent rise in domestic credit.

The modest increase in domestic lending results from weak economic activity. Total credit to the non-state sector declined by 7.7 percent in 2002/03, below the targeted rise of 4.8 percent, following a 7.1 percent drop in 2001/02. Credit to the Government increased by 9.8 percent.

In regard to Population and employment, population has been growing at a high rate since the early 1950's, when it rose to more than $2 \%$ growth per year. Currently the population is estimated at about 68 million with a $2.73 \%$ growth rate per annum (2000-2005). Continued growth at that rate will result in the population doubling over a generation (27-28 years), and the growth rate may be higher than estimated. The challenge of such high growth rates is indicated by the low percentage of the population that has completed primary education, the existing unemployment problem, land degradation and the increasing food insecure population in many areas.

Unemployment manifests itself mainly in the form of underemployment. Open unemployment is concentrated in the urban areas. Youth unemployment is a major social problem. To address and enhance the contribution of the Youth to sustainable development Youth Policy has been formulated with broad based participation. Currently the Policy is under review for approval by the Council of Ministers.

\subsection{Fiscal, monetary and Foreign Exchange Policy}

The Government has a strong track record in sound macroeconomic management and reaffirms its commitment to maintaining macroeconomic stability by pursuing sustainable fiscal policies, and a monetary stance that is non-inflationary, even as it seeks to vigorously promote economic growth and poverty reduction. Despite the severe drought and continued deterioration of the terms of trade, most performance benchmarks have been met. At the same time, reflecting current realities, the targeted average real GDP growth rate has been revised down to about 6 percent. The Government's current plan calls for reducing the external current account deficit, including official transfers to about 6.2 percent of GDP (or 10.6 percent if official transfers are excluded) by $2005 / 06$.

The Government will continue to maintain a cautious expenditure policy, while making every effort to increase poverty-reducing spending. The budget for poverty-targeted outlays (health, education, agriculture, roads) is estimated to have increased to 17.6 percent of GDP. 
With the establishment of the inter-bank foreign exchange market in October 2001, the Government moved towards allowing greater market determination of the exchange rate. During fiscal year 2002/03, a total of 588 trades valued at USD 160.4 million were carried out in the inter-bank foreign exchange market, an increase of USD 56.4 million over the previous year.

The Birr has continued to depreciate in the daily inter-bank foreign exchange market at a 0.45 percent annual depreciation of the average weighted inter-bank exchange rate during fiscal year 2002/03, a considerable deceleration from the 2.58 percent depreciation rate recorded during the previous fiscal year.

More recently, there has been a revival in disbursement of Loan to non-government sector. During fiscal year 2002/03, and reflecting its increasing importance in the economy, the private sector took 87 percent of total loans disbursed, while the public enterprise and cooperative sector absorbed 5.5 percent and 7.5 percent respectively. However total credit to the nongovernment sector declined by 7.7 percent compared with 2001/02. On the supply side, private banks have been steadily gaining market share. Their share of total new credit rose from 36.6 percent in fiscal year 2000/01, to 44.1 percent in fiscal year 2001/02, and to 57 percent in fiscal year $2002 / 03$. Most of the new loans went to domestic trade ( 30 percent), foreign trade ( 22.3 percent) and industry (13 percent). At the same time, the agricultural sector, which accounts for nearly half of GDP, received only about 10 percent of total new loans.

The banking system, as in 2001/02, is faced with excess liquidity in 2002/03, although there are increased sales of government securities. The banks excess reserve increased to $12.8 \%$ in end $2002 / 03$ from $8.1 \%$ at end 2001/02 in reflecting weak credit demand emanating from overall economic growth decline in $2002 / 03$

There has been a significant liberalization of interest rate policy. All interest rates are marketdetermined, except for the saving deposit rate, which is set at 3 percent. Given that the core inflation rate is 3 percent, the fact that interest rates are now in the 3-14 percent range is considered adequate. The term structure of interest rates has not changed significantly during fiscal years 2001/02 and 2002/03. Since the directive allowing banks to pay interest on demand deposits, the demand deposit rate has remained steady at 0.75 percent. The average interest rate on time deposits rose slightly, from 3.47 percent in fiscal year 2001/02 to 3.6 percent in 2002/03, due to modest competition among banks to attract deposits of longer-term maturity. The minimum and maximum lending rate remained unchanged at 7.5 percent and 13 percent respectively. The average lending interest rate stood at 10.5 percent.

\subsection{The Impact and management of the Drought}

\subsubsection{Spatial Distribution of Drought And Number of People Affected}

The 2002/2003 FY saw one of the most widespread and severe emergencies ever to strike Ethiopia. This crisis was particularly serious, because of its wide geographic spread, especially to traditional non-food deficit areas of SNNPR, Arsi in Oromia and East Gojam in Amhara.

In the year 2002/03, frequent needs assessment were conducted by the DPPC in conjunction with donors, NGOs, United Nations agencies and regional authorities. Consecutive appeals have been 
issued in January, August, September and December of 2002, and in March and April of 2003. Through all of these efforts, the dangers of drought had been averted through the Early Warning System. However, the January 2002 appeal was based on the assumption that the relief needs would decline as of July 2002 as it was hoped pastoralists, particularly in Afar and Somali would become self-supporting following the March - May rains. Despite early positive projections, rains failed in many of the pastoral areas and the failure of the Belg(small season) crop (with significant damage to long-cycle crops, particularly in the eastern and southern lowlands) deprived the affected populations of access to food during a critical period of the year.

The most recent estimates suggest that 13.2 million people were in need of food assistance in 2003, compared with about 5 million in a normal crop year. Food assistance needs for 2003 have been estimated at 1.85 million metric tons of cereals. As of end- October 2003, 1.77 million metric tons have been pledge and 1.44 million metric tons delivered.

Overall, the food security situation both in the cropping and pastoral areas was very poor. For the affected populations, household food production collapsed, while cereal price hikes, and falling livestock prices eroded purchasing power. Relief requirements in January 2003 were estimated to total 1,461,679 MT, including 1,329,344 MT of cereals, 128,070 of blended food and 12,000 MT of oil. Further upward revisions in the estimated population in need of food aid were made in April 2003, with 12.6 million people estimate to be in need of immediate assistance, and the food requirement rose to 1.54 million MT, and 81USD million in non-food assistance. Regarding donor response 1,680,165 MT food aid has been pledged of which 1,077,276 MT is delivered up to end of June 2003. Similarly, unparalleled response for non-food needs has been made.

Relief distribution has been mainly implemented by the DPPC and NGOs. In 2002 from July to December about 322,013 MT and from January up to June 2003, 388,471 Mt food was allocated and transported to all regions by DPPC and 99,604 MT and 412,879 Mt of food in 2002 and 2003 respectively was distributed by NGOs. In total, about 1.23 million MT of relief food has been distributed during the reporting period in various regions, including grain, oil and supplementary food. The largest contributions came from USAID and EU.

During the reporting period the Emergency Food Security Reserve (EFSR) provided 1,017,828 MT of grain on loan to the Disaster Prevention and Preparedness Commission (DPPC), World Food Program and Non-Governmental Organizations, from its strategic warehouses located nearest to the drought prone areas. 879,579 MT of grain that had been provided earlier on loan has been repaid. The draft terms of reference for the study to be conducted on the optimum stock of the EFSR, are being prepared jointly by the EFSRA and EU (the funding agency).

\subsubsection{Longer-term responses to drought}

The increase frequencies and the broadening of the effect of the drought has sharpened the sense of urgency in Ethiopia. Realising this and that Ethiopia cannot continuously rely on food aid, Government has launched a major new initiative, the New Coalition for Food Security for Ethiopian. This is discussed in the section on food security. 


\subsection{Assessment of Poverty Status}

During the first year of SDPRP, there was no new survey conducted to provide information to assist to measure short-term changes in poverty. However, as noted earlier the severe drought affecting millions and resulting in 3.8\% decline in GDP growth as well as the continued suppressed coffee prices, indicate conditions have probably worsened for the majority.

The poverty analysis based on the 1999/00 HICE \& WM surveys, which has been incorporated in the SDPRP document, showed the number of people below the poverty declined by about $3 \%$ compared to the results based on the 1995/96 HICE Survey data sets. Owing to the realization of participatory poverty assessment (PPA) to complement results from quantitative analysis, the design of the PPA study is already completed and the study is due to be conducted during the 2003/04 fiscal year.

Micro level studies conducted by the Save the Children-UK entitled "Destitution in the Northern High Lands-Amhara Region, November 2002" and "Ethiopia: Risk and Vulnerability Assessment, August 2003" conducted by the World Bank based on the $1999 / 2000$ HICE Survey have shown that poverty in the country is deep and wide in a sense that half of the population remains persistently poor and another $14 \%$ who are not poor now have a high probability of falling into poverty in the future with a single large shock. The most pervasive of the risks are community wide risks such as weather, malaria \& the newly emerging HIV/AIDS and idiosyncratic health shocks.

The continued collapse of the world coffee price in the last four years highly affects the peasant sector (small farmers) who are the dominant feature of Ethiopia's coffee production which accounts for $95 \%$ of the total coffee production. So the persistence of this shock, will make a large fraction of Ethiopian households lose the return on their long-term investment (perennial coffee trees) and deepen already high poverty levels. The Shock also affects the urban population by collapsing the business environment for coffee productions and also the coffee sector employs which accounts over $25 \%$ of the country's active population (directly or indirectly) migrates to the towns \& deepen the poverty of the urban population.

\subsubsection{Growth and Poverty}

I $t$ is to be recalled that for the preparation of the SDPRP, a study was initiated on sources of Growth, Growth and Poverty Linkages. In 2002/03 this study is made to continue to through new dimensions.

The source of growth study used growth accounting exercise based on a Cobb-Douglas production function estimated using data for the last four decades. A number of conclusions can be drawn from the preliminary results of this study. First, both the short and long run growth models employed show the dominant role of labour in accounting for the positive growth in the period under analysis (in the rage of 0.70-0.90, while capital being about 0.30). Second, the contribution of capital, although disappointing in the first two regimes (Imperial and Derg), seems to pick up in the 1990s. Third, over the entire period, the average contribution of capital is negligible while that of labour and factor productivity is generally positive and significant. 
Finally, the contribution of factor productivity, although not impressive (being negative in some of the drought years), is in general positive. The major conclusion that could be made from this is that growth in Ethiopian is predominantly explained by labour.

The study also shows other interesting features of growth in Ethiopia. First, rainfall variability appears to be the significant variable in explaining variability in growth. In most of the cases, a good rainfall is accompanied by a bumper harvest and higher growth rate. Terms of trade movement and change in real exchange rate are also the other significant variables in explaining growth variability while change in inflation rate and aid is found to be insignificant in explaining growth variability.

The study complemented this macro-data-based analysis by using micro data of rural households of year 2000. The implication of the micro-data based finding for the time series-based (macro) model is that the 'dominant' contribution of labor observed in the latter might have resulted from the omission of the land variable in the model. Thus, we have also estimated the production function using only labor and oxen (as a proxy for capita). This has resulted in a very high coefficient (0.83) for oxen, the labor coefficient being 0.39-thus supporting our hypothesis about the importance of land as omitted variable.

Since the micro-data based growth accounting exercise is focused on rural (agricultural) areas, the study also examined the same issue in the manufacturing sector (which has nine sub-sectors). The result shows that capital is not an important explanatory variable in the case of wood and textile producing sectors. On the other hand it is found to be very important in the tobacco, food processing and leather industries. In general, the values of the capital share ranges from 0.19 to 0.74. The difference in the value of the capital share may suggest that the contribution of total factor productivity or efficiency (TFP), capital and labor for growth in output is different in each manufacturing sub-sector. Specifically, a higher value of the capital share suggests that the contribution of TFP is lower). The result also shows that except for food and tobacco producing sectors, the average the capital share value of 0.25 is acceptable given that the remaining seven sectors have somehow closer value to the average.

The source of growth study has also used a Social Accounting Matrix (SAM) and an Input-output (IO) table for 1995 to examine the interrelation between different sectors. The result of such analysis makes it clear that the multiplier effects of the agricultural sector is very strong when a SAM based model, as opposed to IO model is used. This is because agriculture, through its demand effect, has strong multiplier effect on the economy. The SAM framework offers a perspective on what the likely constraints of output growth might be, if not its predictability. Although the framework is static and assumes output is demand constrained, it is helpful to pinpoint at the linkage between the industrial and agricultural sectors. From the preliminary investigation we noted that: (a) the multiplier effect of agriculture is better than the industrial sector once the analysis is carried in a SAM, as opposed to IO, analytical framework, (b) identification of sources of growth from the perspective of macroeconomic and sectoral interaction reveals that agricultural growth is dependent on the total multiplier effect of the industrial sector. In particular, food processing, textile and non-metal industries have the highest linkages. 


\subsubsection{Social Impact of the Introduction of the Value Added Tax (VAT)}

The newly introduced VAT has a uniform rate of 15 percent on most goods and services, with a zero rate on exports and exempted goods and services. The scope of exempted goods and services differs from that under the sales tax. Under the new VAT, the main items exempt are sales of used dwellings, financial services, medical and educational services, electricity, kerosene, water, and transport services.

This is a preliminary study done with the help of IMF technical assistance. Further detailed study is being conducted. The result indicated here are therefore, preliminary. It needs substantive review and drawing firm conclusions by the Government.

One characteristic of the Ethiopian economy is the high percentage of population that consumes home-produced goods and services. Thus, this portion of the economy is not exposed to indirect taxes. In the 1999/2000 HICE survey, consumers were asked if their expenditure was made in the form of cash or in kind. In-kind payment broadly incorporates home-produced and consumed goods and services as well as goods and services received free, in trade, or as gifts from outside the household. Thus, goods and services in-kind were taken as a proxy for homeproduced goods in which indirect taxes is not applied on them.

The simulation results were finally crosschecked with the available national data on tax revenues. Since the latest available sales tax revenue collection was for 2001/02, this figure was inflated to 2002/03 values using the nominal GDP growth rate between 2001/02 and 2002/03. From this adjusted figure and the aggregate sales tax revenue from the simulation, the estimate of "home-produced" goods that is not subject to the VAT stood at 26.6 percent of consumption. This ratio was applied uniformly across all the households to establish the amount of VAT and sales tax.

The tax incidence of the VAT was analyzed on the basis of the baseline model. The national average effective VAT rate is estimated at about 4.8 percent. As indicated in Table 2 below, households in the sixth decile face the lowest effective rate at 4.2 per cent, while the tenth decile (the richest expenditure group) faced the highest at 5.8 per cent. The analysis conclusively indicated that the VAT is progressive at the national level. However, because it has fewer exemption and only one rate, it is less progressive that the sales tax it replaced.

The estimated progressivety of the VAT depends entirely on the shares of consumption of exempt items and items obtained in kind. Although the magnitude of these two groups taken together is higher for the lower deciles, the implication for each of the groups is different. The analysis also indicated that the percentage of in-kind transactions stays well above 50 per cent for all but the last decile. This adds to the progressivety of the VAT. The study has also considered the distribution effects of exempt items. It is worth noticing that mostly the households in the highest decile consume the exempt goods and services. 
Table 2: Tax Incidence of VAT by Deciles

\begin{tabular}{|l|c|c|c|}
\hline Decile & Average Expenditure (Birr) & $\begin{array}{c}\text { Average VAT Payment } \\
\text { (Birr) }\end{array}$ & $\begin{array}{c}\text { Effective VAT } \\
\text { Rate (\%) }\end{array}$ \\
\hline 1 & $1,688.76$ & 73.27 & 4.34 \\
\hline 2 & $2,593.04$ & 117.08 & 4.52 \\
\hline 3 & $3,206.68$ & 139.69 & 4.36 \\
\hline 4 & $3,747.69$ & 162.03 & 4.32 \\
\hline 5 & $4,301.92$ & 185.15 & 4.30 \\
\hline 6 & $4,895.82$ & 206.47 & 4.22 \\
\hline 7 & $5,582.59$ & 245.35 & 4.40 \\
\hline 8 & $6,531.42$ & 289.52 & 4.43 \\
\hline 9 & $8,028.06$ & 375.76 & 4.68 \\
\hline 10 & $13,839.50$ & 800.57 & 5.78 \\
\hline & & & 4.77 \\
\hline Average & $5,442.49$ & 259.54 & \\
\hline
\end{tabular}

This study has also compared the incidence of the VAT with that of the incidence of the sales tax. According to the study, the effective sales tax rates are lower than the effective VAT rates as many of the goods and services had lower rates under the sales tax than the VAT. On average, households faced an effective tax rate of 3.88 percent, which is 18.7 percent lower than the rate under the VAT (4.77 per cent). In other words, the replacement of the sales tax by the VAT has increased the tax payment burden for the average household.

The study also indicated the increase in tax burden (as a percentage of household expenditure) owing to the shift from the sales tax to the VAT. The VAT is more efficient, although it does shift some of the relative burden of the tax on the poor. The study may seem to indicate that the replacement of the sales tax with the VAT has had an adverse impact on the poorest 40 percent of the population. However, the impact is small (about one percent of their consumption). As this is only half of the story the study also indicated that if the additional revenue is spent primarily on the poor (primary education and health care), the net incidence will be mitigated or reversed.

Distributional analysis for food and non-food items was conducted separately. The share of food expenditure is above two-thirds for most of the households in the survey. As the average share of in-kind expenditures is higher for food than for non-food items, the effective VAT rates on food is lower. The share of exempt and in-kind expenditures in the non-food category does fall as income increases, so the effective tax rate increases monotonically from lower to higher deciles, with the national average being about 5.2 per cent.

About 17 percent of Ethiopians lived in urban areas in $2002^{4}$, but this share has been growing rapidly since the 1990s. This fact is important, because the incidence of the VAT on rural

\footnotetext{
${ }^{4}$ Currently, Ethiopia is one of the least urbanized countries in Africa, but with its urban population growing at about 6 percent annually, the level of urbanization is expected to reach about 30 percent by 2020 .
} 
households is very different than the incidence on urban households for two reasons: income levels are higher in urban areas and the share of in-kind expenditures is much larger in rural areas. For example, the average expenditure in the richest decile is almost 2.5 times higher in the urban areas than in rural areas, but the incidence of the VAT is more than three times higher for urban households in this decile. On average, urban dwellers face an effective VAT rate of 7.8 percent, while rural dwellers pay 4.0 percent in VAT.

\subsubsection{The Impact of the Continuous Decline in International Coffee Prices}

This is not a formal PSIA, but rather an assessment of the situation of coffee sector. In the future, it requires due attention for deeper analysis.

Coffee prices have been declining sharply since the mid-1990s, reaching its twenty years low, with little prospect of a long- term recovery. This has shattered livelihoods. Following the slowdown in coffee prices in world market, the overall decline of prices at farm gate level has seriously affected the livelihoods of smallholder coffee farmers. More than 95 percent of coffee production in Ethiopia comes from smallholder coffee farmers. Many farmers have been forced to sell assets that they had purchased on coffee boom years. They are reducing household food consumption, and rural poverty and inability to pay tax and debts has increased. They are pooling children out of schools. The total impact of the decline in prices has been very damaging at farm household level.

The decline in coffee farmers income meant businesses in towns in coffee growing regions of the country have also been seriously hit resulting in loss of urban employment and income and erosion of livelihoods. Seasonal labourers who normally depend on seasonal coffee picking and coffee processing industries to supplement subsistence agriculture have lost their income opportunities and joined the food insecure households.

According to Oxfam report, the price of coffee has fallen appallingly low and the long-term prospects are grim (Oxfam, 2002). Coffee farmers, the majority of whom are poor smallholders with land holdings less than 0.5 hectares, sell their coffee beans for much less than their production cost. They are unable to pay for their children's education and get basic medicines. They are also obliged to cut back on their daily food consumption, eating only one meagre meal a day or go without it.

At the same time, the whole economy is suffering as coffee, which constitutes the lion's share of the country's foreign exchange earnings, is in trouble. Coffee traders are also at risk and some of them are going out of business. Banks, too, are facing an increasing number of defaulters on their loan.

At the national level the impact is massive. A simple calculation indicated that, Ethiopia has lost about 814 million US Dollar in export revenue over the last five years. Besides, owing to the price crisis the government had withdrawn coffee taxes estimated at 16 million US Dollars. This brings the total direct loss to 830 million Us Dollars. This is very big sum for poor country like Ethiopia. This money could have accomplished the following: 
Dstablishing fully equipped 2000 primary schools (grades 1 to 8 ) and fully equipped 1252 Health Centres or;

$>$ Establishing about 10 High standard Hospitals or;

$>$ Establishing more than 100 well equipped and facilitated High Schools or;

$>$ Construction of Two Hydropower plants that can produce about 360 Megawatts or;

$>$ Construction of about 3,600 kilometres of feeder roads in the nation.

From this, it not difficult to see how households are thrown into destitution, how development works for sustained growth and poverty reduction jeopardized-of course its implication on debt sustainability.

Highlight of some of the important measures the government has undertaken to address the problem include the following:

$>$ The government has abolished the 6.5 percent export tax levied on export coffee and has exempted farmers and traders from the withholding tax of 5 percent;

$>$ Recently, the National Bank of Ethiopia has waved the coffee price setting practice to create flexibility in foreign trade negotiation of coffee exporters;

$>$ The government is also investigating as to how to improve coffee extension service and raise the yield and quality of coffee;

$>$ There is an attempt to diversify the market, particularly the specialty, organic and fair trade markets;

> The Export Promotion Agency is making efforts to play a crucial role by investigating new markets, solving some of the administrative bottlenecks faced by exporters and by reducing the marketing chain.

> Similarly, other export sector related incentive schemes such as foreign exchange retention scheme and permitting external loans and suppliers' or foreign partners' credit facility have been introduced to expand and/or improve coffee production and processing;

$>$ The formation of cooperative union is also another attempt envisaged to solve the problem. To minimize the financial problem of cooperative unions, the formation of a cooperative bank is under process;

$>$ Establishing a coffee development fund is also in the pipeline

However, given the magnitude of the crises and devastating impact of the price fall, these moves alone will not be expected to solve the crises, nor address the problem adequately.

More than any thing else unfair trade practices such as those in coffee sector, have increasingly marginalized poor farmers and governments in coffee producing countries from the envisaged benefits of globalisation, and that the international community has a moral obligation to pay utmost attention to the crises and weak voices of the poor coffee farmers and struggling economies such as Ethiopia. 


\section{$\underline{\text { IV. Overview of Developments in the Pillars of SDPRP }}$}

\subsection{Agricultural Development Led Industrialization (ADLI) Strategy}

ADLI is a long-term strategy, during the first stage, and agriculture is to play a leading role in the growth of the economy. The immediate need is agricultural development to increase food security. Given the limited domestic market, over the medium term when food security has been improved, agriculture has to be made internationally competitive, with surplus agricultural output being increasingly oriented towards exports. To achieve this, the strategy emphasizes technical progress in agriculture and agro-processing, output diversification, and greater market interaction. The following section sets out the steps that have already been taken to do this.

While the strategy emphasises the leading role for agriculture, linkages with other sectors are seen as crucial in building inter-sectoral links, the strategy recognises the key role of non-state actors, particularly the non-peasant private sector in processing agricultural products and in agricultural marketing. The success of the strategy will depend on enhancing the private contribution, both domestic and foreign, to agricultural development, and promoting cooperatives, which are also important in marketing and, along with other micro-finance institutions, in rural finance.

To improve the performance of the grain marketing system, the Warehouse Receipt and Inventory Credit System was recently established to address the problem of high seasonal price variability, poor storage and transport infrastructure, and limited access to commodity finance. This project will provide smallholder farmers with low-cost financing, thereby enabling them to sell their grain during periods when prices are high, rather than immediately after the harvest when farm gate prices are usually at their lowest level. The first phase of this project has been completed and a technical task force made up of representatives from relevant public and private bodies formed. The task force will focus on insurance and performance guarantees, grading standards and grain handling, the warehouse receipt system (paper or electronic), market information, the food aid and warehouse system, and the development of commodity exchange systems. A regulatory body to control and coordinate the credit system is in the process of being established.

Another critical area is the improvement of the efficiency of the inputs markets. To ensure a successful harvest in 2003/04, externally financed Government intervention in fertilizer and seed markets was required. Following the drought, a series of actions have been agreed upon which will gradually improve the competitiveness and efficiency of the fertilizer market. These include (i) a reduction in the proportion of extension staff involvement with fertilizer delivery and credit administration from $30 \%$ in 2004 to zero in 2006, (ii) complete phasing out of Regional Government fertilizer credit guarantees by 2006; (iii) training $80 \%$ of cooperatives' to access bank credit by 2006, (iv) the introduction of a warehouse receipt system, (v) increased credit provision by micro finance institutions. In addition the Government will, (vi) conduct a study to evaluate options for improving the importation and distribution of fertilizer, with implementing the findings of the study in 2006. 
Improving the rural financial services is a key component of the strategy to bring about the shift from subsistence farming to small-scale market oriented agriculture, and to expand and diversify the range of non-farm productive activities. To strengthen the rural credit system and to respond to credit demand from poor rural households so that they can adopt improved agricultural production technologies and undertake off-farm and non-farm income-generating activities, the Government is undertaking rural financial intermediation program (RUFIP) to be managed by the Development Bank of Ethiopia. Within the cooperatives sub-sector, Government will promote the establishment of 3,375 RUSACCOs as self-reliant, member-owned and managed, community-based financial intermediaries.

On implementing Rural Policies and Programs, the immediate need is expansion of agricultural production to enhance food security both improving food supplies and raising the incomes of rural households. In implementing the rural development strategy a key element is the more effective mobilization of human and natural resources, particularly through decentralization and the empowerment of the grass-root level communities for participation in all development interventions.

The structural transformation objective is aimed at accelerating growth through sustained increase in agricultural productivity accompanied by industrial development. Towards this end, in agriculture, actions have focused on developing and implementing menu based extension package; producing the necessary human resources through agricultural TVET; overcoming market constraints; provision of rural financial services; rural road to expand access; improving land tenure security; and the development of cooperatives.

Elements of the Rural Development Policies and strategies include modernization of the research and extension system, which must be demand-driven, and creating a favourable environment for commercial agriculture. To promote agricultural growth, a number of improved appropriate technology packages are being prepared and disseminated to smallholders through menu-based extension packages at household level to enhance commercialisation of smallholder agriculture.

With regard to land tenure, four regions (Tigray, Amhara, Oromya and SNNP) have already issued rural land proclamations and established land administration institutions to enhance land tenure security, in a view to provide farmers with a more flexible and transferable user rights and with incentive to invest in upgrading the productivity of rural land. Another four regions will enact rural land proclamations in the coming two years. Giving higher regard for the specificity of each region, harmonization of the best practices will be made in year 2004/05.

With regard to fertilizer and seed inputs, in order to improve the competitiveness and efficiency of the fertilizer marketing chain, a set of actions are designed to take place in 2003/4, which include conducting a study to explore the options for reforming the market structure for the import and distribution (including wholesale and retail) segments of the fertilizer market.

In order to establish a sustainable agricultural input credit administration system, amongst other measures, regional government guarantee for input credit, which is currently $70 \%$ of the total 
annual fertilizer sale (equivalent to $194,0000 \mathrm{MT}$ ), will be incrementally reduced to completely phase it out by 2006.

In an effort to promote fertilizer use with more responsive technical advisory service, number of extension personnel disengaged from agricultural input delivery system and credit administration is currently increased to $70 \%$, with a complete disengagement by 2006 .

A total sale of 159,220 quintal of improved seeds has been realized in the reporting period and planned to increase to 180,236 quintal by year 2003/04. With regard to agricultural productivity, average productivity for major crops stood at $21 \mathrm{qt} / \mathrm{ha}$.

With regard to development of agricultural cooperatives, given the key role cooperatives play in facilitating marketing and rural financing in rural areas. Amongst other factors, reforming and strengthening cooperatives lead to improvement in the functioning and efficiency of agricultural input and output markets. To this effect, 23 new primary and 6 new secondary cooperatives have been established, other 786 restructured under the New Cooperative Proclamation, and one cooperative bank established. Besides, the study and design for establishment of one cooperative training institution is under way. In respect to human resource development, 3,111 cooperative personnel received short-term training during the year under review.

In regard to introducing menu-based extension, packages have been developed with the intention of moving from piece meal approach to integrated approach. In this connection, about 36 menu-based integrated packages focusing on livestock development, crop production and natural resources management have been developed and implemented during 2002/03.

In an attempt to implementing these packages, the four major regions: Oromiya, Amhara, SNNPR, and Tigray have embarked upon conducting household socio-economic survey prior to interventions. Tigray and Amhara regions have already taken measures to implement the program on 91, 593 households \& the remaining two regions; SNNP and Oromyia have finalized preparations to embark upon implementation on 60,515 households for which they have completed the socio-economic surveys.

Parallel to this, the national agricultural extension intervention program is underway in all regions following the routine extension program. About 4.1 million farmers have been involved in the program. Nine proven technologies are tested for adaptation and popularisation. Out of the 4.1 million extension program beneficiaries, $2.5 \%$ is considered as women farmers. What next? What a remains is assembling and packaging of best technologies and practices and provision of training for extension staff to take off implementation.

In the area of water harvesting, the technique is considered to be one of the major interventions to overcome the challenges of household food insecurity in the country. In this regard, efforts are underway to construct water-harvesting structures across the country. Water harvesting schemes are generally viable, with an economic rate of return of $32.7 \%$, and an annual earning of about ETB 6,400 household/annum. 
Accordingly, 139,462 different types of water harvesting structures with different capacities have been constructed in the four major regions. These structures are at household level and are meant for life saving irrigation for field crops as well as for vegetable gardening where conditions are favourable.

Table 3: Distribution of Water Harvesting Structures

\begin{tabular}{|c|r|}
\hline Regions & \multicolumn{2}{|c|}{$\begin{array}{c}\text { \# Water harvesting } \\
\text { Structures constructed }\end{array}$} \\
\hline Amhara & \\
\hline SNNP & 41,989 \\
\hline Oromiya & 9,177 \\
\hline Tigray & 66,740 \\
\hline Total & 21,556 \\
\hline
\end{tabular}

Formulation of Comprehensive Development Plan: A comprehensive development plan for crop and livestock aimed at transforming the subsistence mode of agricultural production system into market oriented production system have been prepared and ready for implementation in the four major regions. The development plans prepared include:

$>$ Cotton comprehensive development plan

$>$ Coffee " " " " "

$>$ Pulse crops " " "

$>$ Spices and oil seed crops comprehensive development plan

$>$ Dairy comprehensive development plan

$>$ Fishery " " "

$>$ Honey " " " "

$>$ Meat and live animals

Areas for the intervention of the plans have been identified and preparation is underway to conduct training program for development agents.

Access to land (resettlement): In the past decades demand for access to productive land became an agenda by the vulnerable and food insecure households. In response to the chronic food insecurity problems, most of the households opt to find way out from such a dire situation. In response to this desperate move by the population and chronic food shortages faced by millions, the government has initiated a pilot resettlement (access to land) programme during the past two years. About 45 thousand households were resettled voluntarily in Amhara, Oromiya, and Tigray regions during 2002/2003. Similar effort is underway in SNNPR.

Enhancing Capacity in the Agriculture Sector: Over the medium term, to increase the impact of the agricultural development program, the human resources in the agricultural sector need to be substantially enhanced. For this purpose, 25 agricultural training centres have been upgraded to Agricultural TVET Colleges, 4 at Federal and 21 at regional level and currently about 28,000 students are receiving training in five agricultural fields namely plant science, animal science, animal health, natural resource and cooperatives. 


\subsection{Decentralization and Empowerment}

The District Level Decentralization Program aims to devolve power to districts, promoting accountable and responsive local government and enhancing democratic participation. Empowerment at the grassroots is seen as a key to the improvement of service delivery. The District level program started in 2001 by legal and administrative measures to devolve powers from the regional and zonal administrative levels to districts (woreda administrations) in four regions (Tigray, Amhara, Oromiya and SNNP Regional states). This second wave of decentralization has been accompanied with initial steps to build capacity in the districts.

The legal base for division of power between districts and Regional states was incorporated in the 2001 revised constitutions of the four Regional states. Parallel with the legal changes, the district level decentralization program in the Ministry of Capacity Building, in cooperation with the Regional states \& MOFED, undertook preliminary studies on institutional, administrative, personnel and fiscal aspects of decentralization and on capacity building needs. Based on these studies and with further refinement at the regional level, institutional structures in 430 districts of the four regional states have been set-up.

Districts have been given greater economic and political power to implement development plans based on locally determined priorities, consistent with national SPRDP goals. District cabinets have been formed with functional representation from key sectors/public bodies, with 18 to 24 sectoral public bodies/offices organized to discharge public service delivery responsibilities. A pool arrangement system has been introduced to deploy staff from zone and regional to districts levels to reduce the cost of decentralization and improve efficiency.

Untied block grants from regional governments to the districts have been introduced along with improvements of the planning, budgeting, financial disbursement, accounting, reporting and monitoring systems. As of 2001, functional assignments of zones and districts were reorganized with the shift of financial power to districts over their own expenditure by 2002. Budgets of districts have been endorsed by district cabinets and approved by councils.

During 2003, attention has focused on identifying gaps and launching capacity building activities in the districts. One ongoing activity is the refinement and consolidation of the legal framework for operations at the district level. For this purpose, an overall assessment has been made of the capacity building efforts of the public bodies involved in district level activities, through field visits and by contacting various agencies to identify capacity building activities which require support. Gaps relating to the enactment of laws and regulations covering some functions have been identified and the need for consultancy support has been recognized. Terms of Reference have been formulated for short-term consulting support through the CBDSD project.

A working manual is being prepared to ensure accountability and transparency of public institutions, and to improve relationships and interactions at the district level. TOR have been developed to hire local consultants for this work, which is scheduled to be undertaken starting 2004. A draft manual for community-grass roots participation at the district level has been prepared. The manual has been drafted with feedback from the Regional States. The document is currently with different stakeholders for comment. 
Short-term training is being supplied in responding to the priority needs of districts. In response to the shortage of skilled manpower, seven areas of training were identified to enhance the knowledge of existing and newly transferred staff. Training has been offered to at least seven staff members per district in 430 districts of the four Regional States. The training has been carried out by trainers at concerned sectoral agencies, lasting seven to ten day in specific planning fields, action plan preparation, pre-implementation, project planning and implementation, reporting and monitoring etc. It was originally planned to train 4730 personnel at the total cost of Birr 6.1million. However, 7948 personnel have been trained at the cost of Birr 5.6 million.

Currently, a five-year program action plan has been produced for the District Level Decentralization Program and as part of the preparation for PSCAP. In order to identify additional gaps and learn from the experience of the four Regional States, rapid assessment will be undertaken in sample districts by expatriate and domestic consultants using IDA funds. TOR for this activity has been formulated and consultants are to be recruited.

There are short and long-term challenges in moving decision-making power closer to the people. As part of the learning-by-doing process, change has been introduced in the four regional states, However, there are still difficult challenges to be faced related to the development of human skills, budget requirements, elaboration and refinement of legal provisions, restructuring of offices, classification on some issues such as reporting and participatory decision making. This is an area, which will require continuing commitment over some years both from the government and development partners.

Decentralization has started operating at Woreda level since the on set of the 2002/03 FY. Obviously, the process is not without transitional difficulties. The first difficulty was the mismatch between what some Woredas got through the block grant and their existing obligation. To overcome the mismatch additional transfer mechanisms were introduced to manage the transition in a practical manner. There are also indications for refining assignment of responsibilities between regions and Woredas. Fiscal reporting also experienced some delay. The process also brought out the urgency of capacity building to realize the objectives of devolution to Woredas. Given the fundamental devolution that took place, it is understandable and is expected to face short-term constraints. Overall, however, the process is being managed well, and when problems are faced, Regions are handling them in a flexible and practical manner. Since the process is evolving, continuous assessment will be made to identify problems and take corrective measures.

\subsection{The Justice System and Civil Service Reform}

\subsubsection{The Justice System Reform Program}

Strengthening the capacity of the judicial system is intended to help protect individual rights, uphold the rule of law and contribute to good governance. A capable and efficient justice system is indispensable to economic development and democracy. The overarching goal of the justice reform program is to create an environment to expedite social and economic development by 
maintaining the rule of law and respect of human and economic rights. The existing system is unequal to this task due to a lack of capacity in the administration and operation of the system and insufficient human resources. As a result there are delays due to protracted court adjournments; law enforcement organs cannot provide the level of protection of human and democratic rights envisaged in the constitution; and the legislative process and oversight of the judicial process are deficient. The reform program addresses these weaknesses.

The program has started to formulate its strategic approach to strengthening the institutions, designing new working system and procedure and developing human resources. The program office has set out an annual working plan focusing on:

$>$ Equipping the justice system reform program with human resources and materials

Undertaking a comprehensive justice system reform program study

Starting to implement the Court Administration Reform program

$>$ Providing training for judges, prosecutors, and the police force.

$>$ Improving working conditions for the police force and public prosecutors

$>$ Establishing a judicial training center at the federal level.

$>$ Finalizing the revised drafts of penal and criminal procedure codes, Administration procedure codes to parliament for approval.

Implementation has begun in a number of areas, including recruitment of staff, initiating work on a national comprehensive justice system reform program study, recruitment of international consultants, and negotiation of international funding. A beginning has been made with court reform, with appoint of steering committees, opening of some regional project offices2, procurement of modern equipment for courts to improve service.

\section{Training programs have included:}

$>$ Awareness training for higher officials of the Courts on the reform program

$>$ Managerial skills training for 92 Presidents and vice presidents of supreme and high courts of the regions

$>$ "Training of trainers" courses for 50 trainees from regional courts.

$>$ Computer literacy training for 270 court clerks and secretaries.

Other activities have included the preparation of a Medium-Term National Capacity Building Strategic Program (PSCAP), coordinating and assisting the federal and regional state government organs involved in the justice sector to prepare their own five-year working plans for the PSCAP. A beginning has also been made with measures to promote the efficiency of police force and prosecutors, relating to police investigation systems (such as forensic laboratory and other facilities), integrated information and communication system analysis and design of prosecution office. Constraints on implementation have included capacity limitation in the area. There is human and infrastructural constraints on the functioning of courts at all levels of government. 


\subsubsection{Civil Service Reform}

The Civil Service Reform Program is an important building block of the SDPRP, as an honest and effective civil service is essential both for the delivery of public services and for the creation of an enabling environment for buoyant economic growth. The five major areas on which reform focuses are: service delivery; expenditure management and control; human resource management; ethics and top management systems.

Over the last six years, a number of studies have been completed on improvements in the effectiveness, efficiency and accountability of the civil service and now being implemented.

\section{Key Implementation Measures:}

The Civil Service Law (Proclamation 262/2002) came into effect in January 2002. A supporting legal instrument, the Discipline and Grievance Procedure (Regulation 77/2002) dealing with discipline and grievance cases arising from the breach of the law was also approved by the Council of Ministers. Following the approval of the law by the federal parliament, most regional states have adopted their versions of the civil service law.

Staff of federal institutions including judges of the Supreme Court, first instance courts and administrative tribunals, were given orientation on the Civil Service Law and Discipline and Grievance handling procedures. About $45 \%$ of the targeted group has received training. Training has increased the awareness among civil servants of their rights and responsibilities. Training is being continued during FY 2002/2003. There were some delays in the development of some procedures by the Federal Civil Service Commission (FCSC), but that has not seriously hampered the implementation of the Civil Service Law.

The Civil Service Code of Conduct: Development of the code of has been going on for the same time and currently the draft Code is being finalized for submission to the Council of Ministers. First phase training on ethics to representatives of federal and regional civil service institutions took place from April to October 2002. Civil service reform offices of federal institutions have continued to carry out training on ethics as part of their 2002/2003 action plans. Although the delay in the adoption of the code delayed application of sanctions, the Ethics Officers appointed in each federal institution closely monitored the ethical behaviour by civil servants.

Medium Term Pay and Employment Policy: Progress has been made on the technical aspects of medium-term pay and employment policy. Although the long-term option is to adopt a points rating system, the existing job classification method is to continue for the short-term. To complete the policy, advice is being sought from an international pay specialist.

A total of 22,620 job descriptions were collected from 104 federal and pilot regional civil service institutions. These were clustered into 21 major occupational groups and 235 sub-occupational groups, and over 1100 classes. Draft guidelines on class and position classification have been completed. The targeted date for the completion of the reform work is set for June 2004. 
The first labour market survey was conducted in 1999 and the second in 2002, concurrently with the family budget survey. A draft policy paper on pay, benefits and conditions of work has been finalized. There is considerable overlap between the Job Evaluations and Grading and Remuneration and Conditions of Service (RCS) projects, which requires integration. Remuneration reform is to be finalized in June 2004.

Service Delivery Policy: The Service Delivery Policy was adopted by the Council of Ministers in 2001. Federal Civil Service institutions have started implementing the policy and most regional states have adopted similar policies. Most federal civil service reform offices have established Customer Services and Complaints Handling units and have finalized the preparation of service standards. They have started receiving and handling client feedback report cards. Encouraging results have been registered and growing client satisfaction has been observed. However, the capacity to implement the policy needs to be strengthened.

\section{Service Delivery \& Performance Improvement Plan (SDPIP)}

The implementation of the SDPIP (and PSIP) is at its initial stage. The CSRP Office has made some improvements to the draft operational manual prepared by Price Waterhouse Coopers (PWC). Currently revision work is underway to address some key issues raised in the consultation process. The draft manual is to be submitted for discussion at a workshop planned for the near future, and implementation is to be launched soon after the workshop.

It is important to underscore the significance of the PSIP as a civil service wide performance management system (including, the focus on self-scrutiny for attitudinal change, business process reengineering and restructuring. Six key federal ministries together with their affiliated agencies have been selected to undertake service improvement measures on critical service areas to bring about immediate results. In this regard the experience of MOTI and Ethiopian Investment Authority is instructive that Institution needs to be transformed to be responsive, efficient and effective. The following example corroborates what has been already said:

\begin{tabular}{|l|l|c|c|c|c|}
\hline \multirow{2}{*}{} & \multirow{2}{*}{} & \multicolumn{2}{|c|}{ Work steps } & \multicolumn{2}{c|}{$\begin{array}{c}\text { Time (days) it takes to get } \\
\text { service }\end{array}$} \\
\cline { 3 - 6 } & & $\begin{array}{c}\text { Before process } \\
\text { reengineering }\end{array}$ & Now & $\begin{array}{l}\text { Before process } \\
\text { reengineering }\end{array}$ & Now \\
\hline 1 & Investment License & & & & \\
& $\begin{array}{l}\text { Individuals } \\
\text { - Company }\end{array}$ & 18 & 4 & 26 & 2 \\
\hline 2 & Trade License & 23 & 4 & 108 & 2 \\
\hline 3 & Investment License & 26 & 4 & 225 & 2 \\
\hline
\end{tabular}

Human Resource Management Information System (HRMIS): Personnel data on 31,577 federal civil servants have been automated as planned. However, installation of the wide area network (WAN) and roll-out of HRMIS across federal institutions could not be carried out due to administrative bottlenecks which resulted in delay of the disbursement of the budget allocated for the activity. The expected time of completion is now set for mid 2004. The more 
comprehensive aspect of HRMIS is only at the developmental stage, as it requires completion of other HRM reform measures. ICT Policy until recently was under the ICT Capacity Building Program of the Ministry of Capacity Building (MoCB). Recently the Council of Ministers has approved the transfer of the program to an ICT Development Authority, which will be accountable to MoCB.

\subsection{Capacity Building}

A number of important developments stands out prominently during the first year of the SDPRP implementation in the context of enhancing capacity at both federal and sub-national levels: the Public Service Capacity Building Program (PSCAP) and developments in Information Communication Technology (ICT).

PSCAP is a federal specific purpose grant designed for capacity building with the objective of enabling federal, regional and local institutions to deliver efficient and effective services. It is also instrument to empower citizens through public participation in local democratic institution and create government environment conducive to value creation.

PSCAP comprises six public sector capacity building sub-programs i.e. Civil Service Reform, District Level Decentralization, Tax Systems Reform, Justice System Reform, urban management and ICT. During 2002/03 preparation of a five year PSCAP Action Plan was carried out for federal and reform across the sub programs.

With regard to PSCAP, the success of woreda and municipal decentralization efforts depends on the development of a robust intergovernmental fiscal framework consisting of appropriate fiscal instruments that can meet the recurrent, capacity building or performance, as well as the investment needs of the local government sphere. The introduction of the Public Service Delivery Capacity Building Program (PSCAP) as a federal specific-purpose, performance-based program represents a significant step in leveraging additional capacity building resources to encourage more efficient and effective use of the regional subsidy and woreda block grant. Progress has been made in preparing plans and operational manual for PSCAP.

With regard to ICT, recognizing the potentials of ICTs for all-round national development, the Government through the MOCB has brought ICTs as one of the national mainstream activities within the overall National Capacity Building Program. The Government has realized that introductions of ICTs will facilitate state transformation and the devolution process and is believed to make differences to the cultural, social and economic transformation of the society. As ICTs cut across all sectors, in all aspects it constitutes an essential building block for the realization of the intended socioeconomic transformation and realization of poverty reduction objectives. Thus, the Government's vision in this regard is to "Develop And Exploit ICTs as an Accelerator for the Attainment of National Development Objectives and Global Competitiveness".

The ICT program is designed to make available the required inputs ranging from those necessary for the formulation and design of national policy and strategies to the building up of national information and communication infrastructures. 
School Net is a strategic component of sector development program related to education; and woreda Net is part of government administration and service delivery component that emerged as major initiative within the overall capacity building strategy and agenda of the government. School Net initiative represents an ambitious and determined effort by the government to use ICTs to immediately tackle urgent problems of quality and access of secondary school education.

In this connection, the government has procured services and products for the installation of broadcasting system and educational contents for 570 schools. Besides, studies are undertaken for development of extra curricula contents through the use of Internet and data centers in the premises of schools.

The Woreda Net is aimed at the use of information and communication technologies to support good governance as well as the woreda (district) level governments to undertake functions under the on-going program of decentralization.

Hence, the government has procured services and products for the installation of IP based videoconference systems at 3 Federal, 11 Regional and 611 woreda administrations and broadcasting system. As the second phase of the initiative, studies are undertaken in the areas of contents, local area networking and Internet pool and data centers establishments at the premises of federal, regional and woreda administrations.

The Government has taken a number of measures with regard to IT based solution for core government functions. The Government is commencing the development and implementation of interim systems (e.g. roll-out of the existing BDA3 and Budget Information System packages at the federal and regional levels) and medium-term solutions (e.g. Integrated Financial Management Information System) in the financial management arena. Similarly, work is being undertaken for personnel systems and land management systems.

Government Information Systems Strategy (GISS) will be prepared in order to ensure coordinating between the ICT sub-program and key business users such as the CSRP Coordinating Office (for financial and human resource management), the Federal Civil Service Commission, MoFED's budget, accounts, and IT departments, as well as the UDCBO. An important element of the GISS is the need for a clear Applications Roadmap to clarify the business case for applications rollout, as well as financial, technical, procurement, and human resource requirements. The government has established ICT Development Authority. While the government recognizes the fiscal implications, implementation challenges and human resources requirements, it is key instrument of transformation with the sense of urgency the situation demands. 
With regard to Urban Development and Management, devolution of power to regional governments and municipalities will ensure that decisions and strategies, including poverty reduction, are formulated and implemented more effectively at the community level. The establishment of well-defined and functioning local institutions such as municipalities as well as grassroots/community structures are prerequisites for any meaningful and sustainable measures to address poverty and other issues. It is for this reason that the GTZ assisted MMPDP and the IDA financed CBDSD are giving priority to decentralised structures and municipalities in the four regions, and the DAG CG supporting an urban poverty action research study for secondary cities.

All the four major regions have, through the GTZ financed MMPDP, put in place legislation establishing municipalities, empowering them with some functional and fiscal responsibilities. The legislation was put in place after comprehensive studies and consultations with the communities and stakeholders in the respective regions. Elections have already been held in some regions and local communities now have Councilors representing them.

By way of introducing urban management reform, a number of towns and cities have been selected in the four major regions of the country :Oromiya, Amhara, Tigray and SNNPR. The number of towns/cities selected to conduct the reform program are 12 in Amhara, 12 in Tirgray, 21 in Oromia and 19 in SNNPR. Details of the list of towns/cities in each region are attached in Annex 2.

Various initiatives are now underway both under the MMPDP and CBDSD aimed at strengthening the municipalities in terms of their organization structures, manpower requirements, capacity building, establishment of systems and procedures and addressing key issues affecting municipalities such as personnel management, financial management, land management, urban planning etc.

Once this process of capacitating and restructuring the municipalities is completed, they will be in a position to improve service delivery. The same process is also, through the IDA financed CBDSD project and proposed PSCAP, going to be repeated in the five remaining regions (Afar, Benishangul Gumuz, Gambela, Harar and Somali). Already procurement of consultants is being done and these consultants will assist the regions with the legal and institutional framework studies with full participation of the communities and stakeholders in those regions.

CBDSD is building capacity for service delivery by municipalities. The linkages of service delivery and urban poverty reduction are very important. The lack of these essential municipal services has been identified as one of the major indicators of the extent and level of poverty in any urban center. Another dimension to the provision of services by municipalities is that availability of services such as water, sewerage, road, drainage, housing, electricity, telephones etc, attracts investment and encourages/facilitates more economic or industrial activity. Increased economic activity has been identified as one of the contributors to sustainable poverty reduction since more opportunities are created for the poor to enter the mainstream of economic activity. Likewise local authorities also need to put in place laws, regulations that encourage the expansion of the informal sector as this has been found to be the one of the easiest and quickest 
way that the poor can obtain employment or increase their income. This could easily be a vehicle for increased opportunities for the poor.

Overall, efforts currently underway by the government to restructure the government and management of urban centers reflects government's continued commitment to strengthen the rural-urban linkages and ensure that urban development is supportive of rural transformationhence rapid growth and poverty reduction. The measures taken by the Federal Government to overhand the Addis Ababa city Administration has already started to show encouraging results. Cities are attempting to increase their revenue in put by optionalizing land fees through rollout of cadastral. In order to further improve urban land lease management, the government has declined to revise the proclamation. This is important and framework for elaborating regional prototype legislation. Efficient urban land delivery is important factor for increased private sector investment. 


\section{$\underline{\text { V.Macroeconomic and structural reforms }}$}

\subsection{Fiscal and Monetary Reform}

\subsubsection{Expenditure Policy and Management}

Ethiopia is acknowledged to have a very high degree of budgetary discipline ${ }^{5}$. A key challenge will be to maintain this strong tradition of financial accountability as the country moves towards fiscal decentralization to the woreda level. In this regard, capacity building initiatives are underway to support devolution of budgetary and financial responsibility.

To strengthen public expenditure policy and management, and to track poverty related expenditures; eight areas of reform activity are identified under the expenditure management and control Reform Program. They are: Public Expenditure Program (PEP), Financial Legal Framework, Budget Reform, Accounting Reform, Cash Management Reform, Financial Information Systems, Internal Audit Project, and External Audit Project.

Getting the programs under way has been slow in 2002/03. To remedy this, Government has completed an assessment report reviewing implementation, problems that have been encountered, and steps to be taken to resolve the problems. Progress with the various components of the program is as follows.

The PEP will establish a medium term public expenditure planning system informed by clearly defined objectives and priorities. The project focuses on the organization, staffing, and management of the capital budgeting process and the Public Investment Program (PIP) at the federal, regional and sectoral levels. The problems encountered in PEP work include a poorly functioning PIP data base management system and limited funding to install a system for PEP preparation. Next steps in PEP work will focus on developing relevant PEP manuals, establishing an in-service "training of trainers" program to support training at the woreda level, and establishing capital budget ceilings.

The financial legal framework project is developing financial administration laws, regulations and associated directives to ensure financial discipline over executive bodies at the federal, regional, and woreda levels. The outputs of this project have included a financial administration proclamation, relevant regulations and directives, as well as workshops and seminars aimed at building awareness among regional and woreda level bodies. Directives have been issued and implemented at the federal level, and extended to regions for regional finance bureaus to adapt. Future tasks include drafting the remaining directives, identifying shortcomings in the new financial laws, drafting and adopting procurement laws and codes, and providing the necessary training for financial administrators.

The Budget Reform program will strengthen budget control by changing the process and structure of the budgeting system. Measures include the introduction of a financial calendar, a new chart of accounts (specifying revenue and expenditure codes that is consistently applied

5 CFAA report (31 March 2003): According to the CFAA, "There is a high level of budgetary discipline in Ethiopia and there is no problem with unauthorized expenditure and government arrears. The risk of corruption and diversion of funds is low." Annex I of the CFAA contains a comparative matrix with other Sub-Saharan countries, which shows that Ethiopia is well ahead of other countries by nearly all measures of public sector financial accountability. 
across recurrent and capital expenditure from the federal to regional levels), and unit cost norms.

In the context of the on-going further devolution to woredas, there is a need for having a consolidated budget to get a complete picture of the fiscal landscape of the country. In this regard, as per the agreement between the Government and the IMF to prepare a consolidated federal and regional government budgets for both the past years and the current budget year including all extra budgetary funds and accounts, efforts have been made to consolidate both the federal and regional governments' budget for the fiscal years 2001/02 to 2003/04. It is important here to mention that there was some delay in consolidation reporting last year due to the going on decentralization. The consolidated budget as per the agreement has been submitted to the Fund before November 30, 2003.

The budget preparation process will be facilitated by the newly developed budget information system (BIS), which is designed to automate the budgeting process, to quickly assess changes in the composition of expenditure by budget category and item of expenditure, and to enable the timely closure of accounts. The new chart of accounts has been implemented by public bodies of the Federal Government and the SNNPR and the Dire Dawa Administrative Council, and will be extended to Tigray and Amhara regions. BIS has been implemented at the federal level and in Southern Regional Government. To improve coordination among the federal budget team, a steering committee made up of members of MoFED and BoFED has been established. The next steps in budget reform include finalizing computerization of the budget process in all Federal and Regional Public Bodies, developing relevant manuals/guidelines in areas such as aid management, cost center budgeting and unit cost development, and issuing directives to implement budget performance monitoring and evaluation (M \& E).

The goal of Accounting Reform is to clear existing accounts backlogs and produce timely accounts, to extend cash accounting to include reporting on key aspects of assets and liabilities, and institute effective asset control, management, and custodianship systems. Technical assistance has been provided to regions and federal institutions to close the backlog accounts. In the Medium Term Program, the government agreed with the IMF in its adjustment and reform program to improve the timeliness, quality, and coverage of Government Finance.

In this regard, the reconciliation of fiscal and monetary accounts of fiscal year 2001/02 was completed with technical assistance from the International Monetary Fund (IMF) and the gap between the two accounts has been reduced to less than 2 percent of the total general expenditure. Similarly, reconciliation of the two accounts for fiscal year 2002/03 is currently well in progress and will be finalized by the end of December 2003.

The Accounts Reform Project has helped reduce the backlog of accounts from 4 to 5 years to 1 to 2 years (one year at the federal level and two years at the regional level). The existing government accounting system has been documented in two volumes. Finalization of the fixed asset manual and the introduction of the expanded double entry-modified cash basis of the government accounting system (including intensive training for over 4000 accounting staff on the new procedures) will enable all public bodies to account for non-cash items such as fixed assets, debtors and creditors. The modified cash basis has been implemented at the 
federal level, and in the Southern and Tigray regions. Efforts are underway to speed up delivery to other regional governments.

Cash Management Reform will implement an integrated system for the use of government cash resources and improved debt management, including the timely collection of receipts, cost-effective payments systems and supporting information systems, and projections of cash flow and borrowing costs. The system design has been completed, existing cash management practices have been reviewed and documented, the procedural guideline for preparation of monthly cash projection and reconciliation has been drafted, and a draft comprehensive disbursement document has been prepared. The next steps in cash management reform will be to streamline government bank accounts, to issue cash management directives on the investment of idle cash reserves and cash flow projections, to prepare a cash management manual, and to automate the treasury payment system.

The Financial Information Systems project seeks to ensure effective control and efficient utilization of resources by (i) transferring MoFED's budget, disbursement, accounts (BDA) and payroll applications to a PC-based system to reduce the risk of computer failure, (ii) implementing the PC-based BDA system in all Regional Finance Bureaus, and (iii) to develop an integrated computerized financial information system (IFMS) across the country. The revised BDA package has been successfully introduced in Oromiya and SNNPR as well as the Dire Dawa city administration. Next steps include revision of the IFMS to take into account ongoing decentralization, pilot implementation at the federal level, staff training for federal and regional public bodies, and full implementation of IFMS at both federal and regional public bodies. VSAT and ICT technology will be used to create a wide area network system for financial information transfer from woredas to regions and vice versa, covering education, health, agriculture and community development. The plan is to first implement IFMS at the federal level while regions would continue to use different versions of the BDA package and web portals.

The Internal Audit Project will introduce international practices of internal audit in all government institutions at all levels. Thus far the project has produced a draft Internal Audit Standards, Code of Ethics for Internal Auditors and a comprehensive Internal Audit Procedural Manual. Workshops have been conducted to review the draft documents and to provide feedback, and the draft documents have been amended accordingly. Next steps include producing final versions of the audit documents, training internal auditors at the federal and regional level, and enhancing technical capabilities of MoFED and Regional Finance and Economic Development Bureaus.

The goal of the External Audit Project is to strengthen the capacity of the Office of Auditor General (OAG) and Regional Auditor Offices (RAOs). A manual covering financial audit, control audit, performance audit and special investigation is planned. Thus far an assessment of existing external audit practices in civil service audit offices has been completed, and manuals and other background documents have been drafted. Next steps include developing training manuals and training auditors to apply the manuals and other capacity-building work. As a result of the recent OAG Audit Report, the Financial and Budget Committee summoned federal Ministers and State Ministers whose financial position and internal control systems were criticized by the OAG Audit Report and instructed them to take corrective action. 
While considerable progress has been made in public financial management and control, particularly at the federal level, there have been problems in implementing components of the sub-programs.

This is largely due to weak capacity at the local level, causing delays in implementation. Ministries at the federal level are working closely with regional and district administrations to improve public expenditure management within the context of overall public service reform and fiscal decentralization to the woredas. MoFED is now preparing a strategic plan to facilitate greater coordination in implementing various components of the Expenditure Management and Control Program (EMCP). The strategic plan will take into account changes in organizational structure resulting from the ongoing decentralization process. Priority is being given to finalizing the closing of FY 2001 government accounts, issuing audited government financial statements for FY 2000, and finalizing the medium-term program for improving financial management.

\subsubsection{Revenue Policy}

The Tax System Reform project aims to create a tax system that is more supportive of private sector development, improving revenue collection, and ensuring equity and fairness of the tax system. The tax reforms that have been initiated will lay the foundations for a strengthened revenue base. Continuing efforts to improve tax administration and collection, including strengthening the large taxpayer unit which accounts for about 75 percent of several tax revenues, have resulted in tax revenues increasing from 15.3 percent of GDP in 2001/02 to an estimated 16 percent in 2002/03.

Reforms have sought to streamline and close loopholes in the income tax, make the incentive system more efficient, strengthen the collection of domestic indirect taxes through selective rate increases and broaden the tax base while relying less on border taxation. The tax reform greatly benefited from the IMF technical assistance specific measures that have been undertaken so far include:

a) Formulation of Tax policy and Legislation

b) Introduction of Presumptive Taxation System

c) Introduction of the Value Added Tax (VAT)

d) Taxpayer Identification Number System (TIN)

e) FIRA Organization

f) Operational Programs, Systems and Procedures

g) ContinUed MEASURES to LIBERALIZE THE TAX REGIME

\section{a) Tax policy and Legislation}

The overhaul of the tax legislations is designed to encourage capital investment and development, establish a sustainable domestic revenue base and ensure equity, fairness and consistency in the administration of the tax laws. In order to ensure that the contributions of the various stakeholders were considered, an extensive consultation process on the comprehensive tax reform measures commenced in early 2002 and is ongoing.

a. The new Income tax Proclamation was introduced in July 2002 and provides for reductions in the corporate income tax rate from $35 \%$ to $30 \%$, the business income tax rate applicable to sole proprietors and partnerships from $40 \%$ to $35 \%$, loss carryforward provisions and new business income tax expenditure deductions. 
b. The VAT, at the rate of $15 \%$, was introduced on January, 1,2003 to replace the sales tax.

c. A Turnover Tax, similar in scope to the VAT levied at the rate of $2 \%$ on goods and $10 \%$ on services and applicable to taxpayers whose annual turnover is below the VAT threshold was introduced on January 1,2003.

d. The Excise Tax Proclamation, which has been rationalized to more accurately reflect the current business environment, was introduced on January 1,2003. The measures include the reduction of the excise tax through the exclusion of depreciation from the computation of the cost production upon which the tax is based.

e. The enforcement powers of the tax authorities were strengthened, in accordance with international practices, which will improve taxpayer compliance.

\section{b) $\quad$ Presumptive Taxation}

Presumptive taxation provides the instrument to broaden the tax base and raise more revenues from the hard-to-tax group, including the large informal sector and taxpayers who understate income. The following measures have been introduced:

$>$ The standard assessment method, applicable to the City and Regional taxpayers whose annual turnover is less than Birr 100,000, to replace the estimated assessment method which was subject to inconsistent application;

$>$ An advance business profits income tax on commercial imports at the rate of $3 \%$ based on C.I.F (cost, insurance and freight).

$>$ A withholding tax of $2 \%$ on payments made by private limited companies, public enterprises, government agencies, non-profit organizations and private non-profit institutions to designated categories of taxpayers.

\section{c) $\quad$ VAT Implementation}

$>$ The FIRA established a separate VAT Department and two new regional offices to administer the VAT.

$>$ The current number of VAT registrants is approximately 6000 compared to the expected 3,500 who actually were registered by January 1,2003. Publicized enforcement actions have resulted in an influx of new registrants, some of whom will be registered retroactively to January 1, 2003.

The combined revenue from the VAT and Turnover Tax is approximately 13.3 percent higher than the sales tax for the comparative period to September 30, 2003. The domestic revenue contribution is approximately 20 percent higher and Customs VAT revenue approximately 8 percent higher than the sales tax from last year.

$>$ An interim computer system, developed by a local company, to support the core VAT business, is operating effectively and efficiently. The more comprehensive system is presently being customized and will be implemented in late 2003.

$>$ The VAT Department is taking constructive actions against the taxpayers who have failed to comply with the VAT proclamation. 
d) Taxpayer Identification Number System (TIN)

A South African company has developed the TIN application software. Although delays have been encountered, some of which were beyond the control of the FIRA and the contractors, significant progress has been made:

The pilot test of the TIN system has been completed at a number of sites in Addis Ababa and at two FIRA regional offices.

$>$ National implementation is underway with completion expected in early 2004.

e) FIRA Organization

The Civil Service Commission has approved the FIRA's organization proposal and the recruitment of 300 additional personnel is underway. The training of 152 graduates is currently in progress and the major capacity will be deployed to FIRA operational functions in Addis Ababa and FIRA regional offices. The main features of the new organization include:

$>$ The strengthening of the taxpayer education, enforcement and MIS organizations;

The establishment of an Investigations Department;

$>$ The establishment of additional FIRA regional office.

Subsequently, the FIRA and the ECuA were granted autonomy and are no longer under the Federal Civil Service Commission.

Operational Programs, Systems and Procedures

A Large Taxpayer Office has been established to manage 500 taxpayers who account for $75-80 \%$ of annual revenues;

$>$ Manual taxpayer accounting systems have been developed for all taxes;

$>$ Operating manuals have been produced for the accounting, audit and collection enforcement business functions.

$>$ The development of the business system requirements for a computerized integrated tax system, to support the administration of all taxes is underway.

g)

\section{$\underline{\text { Regional Cooperation }}$}

The City and Regional tax authorities actively participated in workshops, seminars and study tours and contributed to the development of new tax policies and legislations, the Standard Assessment presumptive tax method, the TIN business system requirements and the registration and education of VAT taxpayers.

The Revenue Sector Reform Program Office has provided training on the new legislations to personnel of the City/Regional tax authorities and to FIRA regional personnel. In addition, $771 \mathrm{City} /$ Regional personnel have received training to date on the Tax Reform Program at the Civil Service College and at Mekele University. Training is continuing on an ongoing basis. 


\section{h) Tariff Reform and Modernization}

Ethiopia being a member of the International convention on the Harmonized Commodity Description and coding system, and following the economic reform program launched since mid-1992 by the Government, the Harmonized System has replaced the former tariff structure in August 1993.

The government has conducted series of customs import tariff amendments and measures have been taken in line with the economic reform program since August 1993. In this regard, the $6^{\text {th }}$ round tariff amendments have been undertaken scaling down the maximum tariff rate from 230 percent to 35 percent. The simple average tariff rate has been reduced from 79.1 percent to 20.0 percent and the weighted average tariff rate reduced from 41.6 percent to 17.5 percent during the same period. In January 2003, the average weighted import tariff was reduced from $19 \frac{1}{2}$ percent to $17 \frac{1}{2}$ percent, the maximum tariff rate was reduced from 40 percent to 35 percent, and the number of tariff bands including zero-rate has been reduced from 7 to 6 .

The IMF Fiscal Affairs Department conducted a review of the Ethiopian Customs Authority (ECA) during June 2003 and provided technical advice for a strategy on reform, which will be taken into account by the reform team. In the meantime, the ECA continue to implement measures to facilitate the clearance of goods and combat smuggling. The migration to ASYCUDA ++ from version 2.7 is underway. The development of the project documentation for the remaining sub-program, and the terms of reference for securing of a senior Customs advisor, for a period of two years is well in progress.

\subsection{Other Structural Reforms}

\subsubsection{Financial Sector Reform}

An effective system of financial intermediation can promote rapid and sustainable economic growth by channelling savings into productive investments. With this in mind, Government is implementing a medium-term strategy to strengthen the banking system, the most important source of investment finance. To put in place the basic financial infrastructure, the financial statements produced by financial institutions and corporations need to be in compliance with internationally accepted accounting rules, a sound auditing process is needed, along with a supportive legal system, good governance, prudent regulation, and a strong supervisory structure. This has been the basic strategy of the National Bank of Ethiopia (NBE)- the supervising authority.

Regulation for bank provisioning for non-performing loans (NPLs) has been revised to bring it closer to international best practice by including five NPL classification categories. A study is underway to establish a credit rating system for medium and large bank borrowers. A restructuring plan has been adopted to address the weak financial condition of the Development Bank of Ethiopia (DBE). The Council of Ministers has approved the proposal to raise DBE's capital from Birr 250 million to a prescribed capital of Birr 600 million, and its non-performing loans (NPLs) have been reduced through the issuance of a bond.

To give lenders reliable information to evaluate the creditworthiness of borrowers, the NBE established the Credit Information Centre in progress, an online database that tracks the liability position of borrowers. To improve the accuracy and reliability of information 
provided to lenders, and to do away with the practice of keeping two different sets of financial statements, one for borrowing, one for tax purposes, borrowers will be required by law to make available to lenders the same financial information that is submitted to the tax authorities.

Additional measures are being considered to improve the legal and regulatory environment, to encourage banks to modernize and adopt improved banking practices, including strengthening credit evaluation and risk management skills. The government also recognizes the need for well-defined and enforceable property rights, including creditors' rights to secure repayment. Specific measures have been adopted to enforce the foreclosure law, so that banks can reduce NPLs and deter delinquency. To increase competition, private banks are encouraged to increase their scale of operations and expand their capital base, including through mergers.

The financial restructuring of the banking sector: (i) a performance contract, set as a structural benchmark for June 30, 2002 under the PRGF arrangement, was signed by the government and the management of CBE on June 28,2002 to ensure that the CBE is operated effectively, on a commercial basis. The management of CBE now has autonomy in decision making, including staffing, meeting performance targets, and pursuing delinquent borrowers; (ii) a new directive on the amendment of provisions was adopted on August 31,2002. The first directive was adopted on March 30, 2002 but was subsequently revised to bring it more fully in line with international best practice. The directive stipulates that full provisioning should be implemented by January 2004.

A legal and policy framework to support the growth of Micro Finance Institutions (MFIs) and Rural Savings and Credit Cooperative Societies (RUSACCOs) was established through Proclamation 40/1996, which assigned supervision of MFIs to the NBE Micro finance Supervision Division. To date, the NBE has licensed 22 MFIs. The growth of Ethiopia's micro finance industry has been impressive. As of June 2003, the MFIs have a combined network of about 1,246 branches and sub-branches, outstanding loans of Birr 527,469,230 outstanding savings of Birr 406,146,370 and outreach to 720,684 poor rural households. Nevertheless, this still represents a very small portion of the potential demand for micro finance, which is estimated to be between 4.2 and 5.5 million households.

MFIs have achieved regional 'best practice' in savings mobilization and have achieved high repayment rates that range from 90 to 95 percent. The nominal return on equity averaged $7.7 \%$ and the inflation-adjusted return averaged $6.3 \%$. The NBE plans to further promote the development of MFIs by transforming them into rural banks and by facilitating the flow of funds from commercial banks to those institutions for the purposes of on- lending.

The Rural Financial Intermediation Programme (RUFIP) managed by the Development Bank of Ethiopia's (DBE's) RUFIP unit has an estimated USD 100 million budget, largely financed by concessional loans from the International Fund for Agricultural Development (IFAD) and the African Development Bank. RUFIP's aims to extend outreach to 1.5 to 2 million rural households, build skills in non-collateral based lending, and improve linkages between rural finance and the formal banking sector. The program aims to train about 40,000 women in business skills development.

The restructuring plan of the CBE includes, among others, (i) a time-bound plan for reducing NPLs to 20 percent of total loans over less than four years by end-June 2007; (ii) a business 
plan to keep the capital adequacy ratio over 10 percent with no capital injection envisaged from the government; (iii) strengthening of credit risk and porttfolio management, with the assistance of consultants from the Bank of Scotland, through improved credit guidelines, organizational restructuring, and staff training.

\subsubsection{Monetary Reform}

As regards monetary reform, the final report of the comprehensive study of the NBE is to be completed by end of December 2003. Subsequent actions depend on the review to the study and adoption of implementation plan. 


\section{Financing the SDPRP and the Macroeconomic Fiscal Framework (MEFF)}

\subsection{Out-turn During the First Year of the SDPRP Implementation (2002/03)}

During fiscal year 2002/03, general government revenue including grants stood at Birr 14,161 million and showed an increase of 10.3 percent over the previous fiscal year (2001/02). On the other hand, total General Government expenditure including special program during fiscal year 2002/03 reached Birr 18,402 million, of which Birr 12,305 million (67 percent) was effected for recurrent expenditure and Birr 5,818 million (32 percent) for capital expenditure

\subsubsection{Fiscal Outturn During 2002/03 Versus the 2002/03 Budget}

\subsubsection{Revenue}

During fiscal year 2002/03, general government revenue stood at Birr 11149 million and showed an increase of over 7 percent over the previous fiscal year (2001/02). This increase is largely attributed to the increase in non-tax revenue by 17 percent while tax revenues showed a modest 4 percent increase over the preceding fiscal year. However, with in tax revenue direct taxes witnessed about 3.5 percent decline over the preceding fiscal year. The decline in the direct tax component is in-turn attributed to the decline in business profit tax largely as a result of overall weak economic activity as a result of the drought.

The overall modest increase (4\%) in the tax component (despite the decline in direct taxes) is because this decline has been more than compensated by improvements in revenue collection following the introduction of the VAT as indicated by the significant increase in domestic indirect taxes.

Notwithstanding the modest increase in domestic revenue over the preceding fiscal year $(7.1$ $\%$ ), overall domestic revenue collection fell short of the 2002/03 revenue budgets by about 15 percent. The biggest shortfall from the budget was recorded by non-tax revenue collection (about $24 \%$ ). Major components of revenues fell short of the 2002/03-revenue budget as indicated in Table 3 below.

During the 2002/03 FY total revenue including external grants stood at 14161 million Birr and showed an about 10.3 percent increase over the preceding fiscal year (2001/02). During the fiscal year, external grants out-turn (mainly emergency and project assistance and CPF grants) increased by over $24 \%$ over the preceding fiscal year (2001/02). During 2002/03 outturn from external grants stood about 8 percent higher than the budget (Table 4 below). 
Table 4: Comparison of 2002/03 Fiscal Out-turn with the Budget, Million Birr

\begin{tabular}{|c|c|c|c|c|c|c|}
\hline \multirow{2}{*}{$\begin{array}{l}\text { S. } \\
\text { N }\end{array}$} & \multirow[t]{2}{*}{ Items } & \multirow{2}{*}{$\begin{array}{c}2001 / 02 \\
\text { Actual }\end{array}$} & \multicolumn{2}{|c|}{$2002 / 03$} & \multirow{2}{*}{$\begin{array}{l}\% \text { Change } \\
\text { over } \\
2001 / 02^{6}\end{array}$} & \multirow{2}{*}{$\begin{array}{c}2002 / 03 \\
\text { out-turn as } \\
\% \text { of Budget } \\
(\%)\end{array}$} \\
\hline & & & Budget & Pre. Actual & & \\
\hline 1 & Domestic Revenue & 10409 & 13128 & 11149 & 7.1 & 84.9 \\
\hline \multirow{4}{*}{1.1} & Tax Revenue & 7926 & 9330 & 8243 & 4.0 & 88.4 \\
\hline & - $\quad$ Direct Tax & 3120 & 3612 & 3010 & -3.5 & 83.3 \\
\hline & $\begin{array}{ll}\text { - } & \text { Domestic Indirect } \\
& \text { Tax }\end{array}$ & 1498 & 1856 & 1668 & 11.4 & 89.9 \\
\hline & - Foreign Trade Tax & 3308 & 3862 & 3565 & 7.7 & 92.3 \\
\hline 1.2 & Non-Tax Revenue & 2483 & 3798 & 2906 & 17.0 & 76.5 \\
\hline 2 & External Grants & 2425 & 2793 & 3012 & 24.2 & 107.8 \\
\hline 3 & Total Revenue \& Grants & 12834 & 15922 & 14161 & 10.3 & 89.0 \\
\hline 4 & $\begin{array}{l}\text { Total Expenditure including } \\
\text { Special Programs }\end{array}$ & 17652 & 21448 & 18402 & 4.3 & 85.8 \\
\hline 4.1 & Recurrent & 10550 & 13220 & 12305 & 16.6 & 93.1 \\
\hline \multirow[t]{10}{*}{4.2} & Capital & 6130 & 7245 & 5818 & -5.1 & 80.3 \\
\hline & - Domestic Source & 2741.5 & 3771.2 & 3264.6 & 19.1 & 86.6 \\
\hline & - $\quad$ External Loan & 2275.5 & 2199.0 & 1852.1 & -18.6 & 84.2 \\
\hline & $\begin{array}{ll}\text { - } & \text { External Assistance }\end{array}$ & 1113.4 & 1275.1 & 701.3 & -37.0 & 55.0 \\
\hline & Regional Subsidy (treasury) & 3847.6 & 4556 & 4523 & 17.6 & 100.0 \\
\hline & $\begin{array}{l}\text { Poverty Targeted } \\
\text { Expenditure }\end{array}$ & 6525.2 & 10339.9 & 8027.5 & 23.0 & 77.6 \\
\hline & - Recurrent & 3093.0 & 4130.4 & 3671.0 & 18.6 & 88.9 \\
\hline & - $\quad$ Capital & 3432.2 & 6209.5 & 4356.5 & 27.0 & 70.2 \\
\hline & $\begin{array}{l}\text { Poverty Targeted } \\
\text { Expenditure as \% of Total } \\
\text { Expenditure }(\%)\end{array}$ & 42.8 & 48.2 & 41.9 & & \\
\hline & Special Program & 972 & 983 & 655 & & 28.4 \\
\hline 5 & $\begin{array}{l}\text { Fiscal Deficit including } \\
\text { Grants }\end{array}$ & -4818 & -5526 & -4793 & & \\
\hline \multirow[t]{3}{*}{6} & $\begin{array}{l}\text { Deficit as \% of GDP @ } \\
\text { CMP (\%) }\end{array}$ & -9.3 & -9.7 & -8.4 & & \\
\hline & Memorandum Item & & & & & \\
\hline & $\begin{array}{l}\text { GDP at Current Market } \\
\text { Prices }\end{array}$ & 51761.0 & 56958.0 & 56958.0 & & \\
\hline
\end{tabular}

\subsubsection{Expenditure}

During fiscal year 2002/03 total general government expenditure including special programs reached Birr 18402 million, of which Birr 12305 million (66.9\%) was effected for recurrent expenditure and Birr 5,818 million (31.6\%) for capital expenditure and the residual $(1.5 \%)$ for special programs. During fiscal year 2002/03, total general government expenditure including special programs showed a 4.3 percent increase over the preceding fiscal year (2001/02). While recurrent expenditure increased by over 17 percent capital expenditure declined by about 5 percent during the 2002/03 FY. The increase in recurrent expenditure apart from relief spending is to a large extent attributed to a boost in spending on povertyoriented sectors. On the other hand, defence spending has been maintained constant in nominal terms and has been declining in real terms. Defence spending has declined from over 13 percent of GDP in 1999/2000 to about 4 percent of GDP in 2002/03. On the other hand,

\footnotetext{
${ }^{6} 2002 / 03$ preliminary actual compared to performance over the previous (2001/02) fiscal year
} 
the decline in capital expenditure is largely attributed to decline in spending (measured by the difference between the out-turn and the budget) from external sources of finance in particular from external assistance. As indicated in Table 4 above, during 2002/03 actual capital spending from external assistance fell short of the budgeted amount by about 45 percent. Provisional actual spending from external loan fell short of the budgeted amount by about 16 percent. With about 13 percent shortfall, development projects financed through treasury sources performed better than projects financed both through external loan and assistance. Given that around 75 percent of capital spending is accounted for by povertyoriented sectors (Table 4 above), the shortfall observed in regard to external sources of finance has had also implication on the performance of poverty-oriented sectors. Although spending on poverty-oriented sectors increased markedly compared to the preceding fiscal year (2001/02), actual utilization has still fallen short of the budgeted amount by a significant margin (about 30 percent) as indicated in Table 4 above.

The share of poverty targeted spending (both recurrent and capital from all sources) increased from 37 percent of total expenditure in 2001/02 to about 44 percent by the end of 2002/03. During 2002/03, despite the decline in overall capital expenditure, capital expenditure on poverty-oriented sectors still showed a 27 percent increase over the preceding fiscal year. During the same year, recurrent spending on poverty-oriented sectors also increased by about 19 percent over the preceding fiscal year. Overall, poverty targeted spending showed a 23 percent increase over the preceding fiscal year (2001/02).

Overall, regions' own revenue finances on average less than 40 percent of their expenditure assignments. The resource gap at regional and sub-regional level has been bridged through federal subsidy (block grants to regions). In this regard, federal subsidy to regions accounted for the bulk of spending by regions and woredas. Regions and woredas account for the bulk of poverty targeted spending (particularly of social spending). For instance, during 2001/02 spending by regions on education and health accounted for 61 percent of total general government expenditure on these sectors. Regions' share on those sectors averaged 60 percent by the end of 2002/03. As depicted in Table 3 above, federal regional subsidy, which stood at over 4.5 billion Birr during fiscal year 2002/03 showed about 18 percent increase over the preceding fiscal year.

During 2002/03, expenditure performance also fell short of the expenditure budget by about 14 percent. The biggest shortfall in expenditure performance during 2002/03 was recorded for capital budget $(20 \%)$ while recurrent spending fell short of the budget by about $7 \%$. The short fall in overall recurrent budget was to a large extent accounted for by defence spending. Overall poverty targeted spending also fell short of the budget by over 22 percent. Capital expenditure lagged way behind the budget (about 30 percent short-fall) while recurrent shortfall stood at about 11 percent. Such a level of shortfall in capital spending has to a large extent been attributed to lags in disbursement from external sources particularly external assistance. With regard to federal regional subsidy, the entire budgeted amount has been transferred to regions (Table 4 above for details). 


\section{Sectoral Performance of Poverty Reducing Spending}

As indicated in Table 3 above, total poverty targeted expenditure, which stood at 8027.5 million Birr during 2002/03 showed an increase of over 23 percent over the previous fiscal year. Of this, 3671 Million Birr was spent on recurrent and 4356.5 million Birr (54 percent) on capital expenditure. Poverty targeted recurrent spending increased by 19 percent while the capital component showed a 27 percent increase over the preceding fiscal year.

Total public expenditure on poverty-targeted sectors averaged 45 and 44 percent of total expenditure in 2001/02 and 2002/03. Recurrent expenditure on poverty-targeted sectors increased from 29 percent of total expenditure in 2001/02 to 30 percent by the end of 2002/03. Capital expenditure on poverty-targeted sectors also increased from 71 percent of total expenditure in $2001 / 02$ to 75 percent by the end of 2002/03.

With regard to sectoral allocation, with in the recurrent component, during 2002/03 education followed by agriculture and food security and health accounted for 19,5 and 4 percent of total recurrent expenditure, respectively. With regard to capital expenditure, road followed by education and agriculture and food security in that order accounted for 30, 15, and 15 percent, of total capital expenditure respectively, during the same year. Overall (for both recurrent and capital), road followed by education and health accounted for 19, 18, and 9 percent of total expenditure during 2002/03. The details on trends in the share of poverty-oriented sectors are depicted in Table 5 below.

Table 5: Public Expenditure on Poverty-Oriented sector as a Ratio of Total Public Expenditure

\begin{tabular}{|l|c|c|c|c|c|c|}
\hline \multirow{2}{*}{\begin{tabular}{c} 
Sectors \\
\cline { 2 - 7 }
\end{tabular}} & $\begin{array}{c}\text { Recurrent } \\
(\%)\end{array}$ & $\begin{array}{c}\text { Capital } \\
(\%)\end{array}$ & $\begin{array}{c}\text { Total } \\
(\%)\end{array}$ & $\begin{array}{c}\text { Recurrent } \\
(\%)\end{array}$ & $\begin{array}{c}\text { Capital } \\
(\%)\end{array}$ & Total (\%) \\
\hline Agriculture \& food security & 5.4 & 15.3 & 8.6 & 4.4 & 14.8 & 7.5 \\
\hline Education & 16.8 & 11.1 & 13.9 & 16.8 & 15.7 & 16.0 \\
\hline Roads & 1.1 & 29.8 & 11.0 & 1.0 & 30.6 & 10.1 \\
\hline Water & 1.0 & 8.6 & 3.6 & 1.0 & 9.4 & 3.5 \\
\hline Health poverty & 4.9 & 7.9 & 5.7 & 3.9 & 7.4 & 4.9 \\
\hline $\begin{array}{l}\text { Total pargeted } \\
\text { Spending (\%) }\end{array}$ & $\mathbf{2 9 . 3}$ & $\mathbf{7 2 . 8}$ & $\mathbf{4 2 . 8}$ & $\mathbf{2 7 . 1}$ & $\mathbf{7 8 . 0}$ & $\mathbf{4 1 . 9}$ \\
\hline $\begin{array}{l}\text { Total poverty targeted spending } \\
\text { (Million Birr) }\end{array}$ & 3092.8 & 4460.4 & 7552.8 & 3671 & 4921 & 8592 \\
\hline $\begin{array}{l}\text { Total expenditure excluding } \\
\text { special program (Million Birr) }\end{array}$ & 10550.0 & 6130.3 & 17651.5 & 13527.0 & 6313.0 & 20495.0 \\
\hline
\end{tabular}

\section{Deficit and Financing During for 2002/03}

As indicated in Table 4 above, total revenue including grants stood at about 14,161 Million Birr while total expenditure including special programs amounted to $\mathbf{1 8 , 4 0 2}$ Million Birr. This resulted in to fiscal deficit amounting to 4241 Million Birr. The deficit was financed through net external borrowing of 3484 Million Birr and net domestic bank and non-bank borrowing of 1653 Million Birr and 8 Million of privatisation proceeds. Fiscal deficit including grants narrowed from $-9.3 \%$ of GDP in $2001 / 02$ to $-7.5 \%$ of GDP in 2002/03. 


\subsection{Updates on the 2003/04-2005/06 Macroeconomic Fiscal Framework (MEFF)}

\subsubsection{Alternative Macro Scenarios and the Rationale}

As indicated in the SDPRP, GDP in real terms was projected to grow at an average rate of 7 percent per annum during the years spanning the SDPRP period (2002/03-2004/05). However, the first year of the SDPRP implementation (2002/03) has experienced the severest drought since 1984/85. This experience confirmed the need for alternative scenarios for the outer years (2004/05 and 2005/06). Information on the 2003/04 FY, the second year of the SDPRP period being the budget year we are already in, is established in most respects. In this regard, the 2004/05 FY receives special focus as it is the last year of the SDPRP. Alternative scenarios (high, base case, and low) have been envisaged for the outer two years (2004/05 and 2005/06). The Base Case is expected to fall in between the High and the Low scenarios for the subsequent two years (2004/05 and 2005/06). The High and Low scenarios are basically considered as deviations from the Base Line in respect of optimistic (High) and pessimistic (Low) scenarios, respectively. As the main source of shocks to the Ethiopian economy has been transmitted through the agriculture sector in terms of variability in output and external shocks transmitted through international prices of primary exports, the High and Low case scenarios are considered to be (for this purpose) the reflections of the agricultural sector in terms of domestic economic activity and external shocks brought about through international prices of exportable such as coffee. Accordingly, the high case assumes normal rainfall with even distribution across the country and relative improvements in international prices of traditional exports such as coffee. The Low case envisages shocks either domestic or foreign or a combination of the two. For the High and the low scenarios, for 2004/05, the 2003/04 recently revised PRGF Program (November 2003) serves as a base for developments in all relevant macro variables.

\subsubsection{Real Sector and Prices}

The binding macro aggregate up on which all other macro variables (fiscal, monetary, and BOP) hinge is the real sector. The magnitude of real GDP growth for the current fiscal year (2003/04) is already established along with the fifth PRGF review (November 2003). Accordingly, GDP in real terms is expected to increase by 6.7 percent during 2003/04. As indicated in Table 6 below, under the Base Case, real GDP growth is projected at 6.4 and 6.1 percent in 2004/05 and 2005/06,respectively.

\section{$\underline{\text { High Case Scenario }}$}

Under the high scenario, overall GDP in real terms is expected to increase by about 7 percent each in 2004/05 and 2005/06,respectively. Real GDP growth rates for the high case are in line with government projections on GDP growth rates during the preparation of the Country Assistance Strategy (CAS) by the World Bank. In terms of real GDP growth, the margin between the high case and the baseline is relatively narrow being mindful of the downside risks of being too optimistic. Real GDP growth under the High Case is projected at 6.9 and 7.0 percent in 2004/05 and 2005/06, respectively. Inflation measured by the Consumer Price Index is projected at 2.8 and 3 percent during the two consecutive years, respectively. GDP deflator is also projected at about 5 percent each during 2004/05 and 2005/06. As a result, GDP at current market prices is projected to increase by $\mathbf{1 2 . 0}$ and $\mathbf{1 2 . 3}$ percent during 2004/05 and 2005/06, respectively (Table 6 below). 
Table 6: Real Sector Projections under Low, Base Line and High Case Scenarios

\begin{tabular}{|c|c|c|c|c|c|c|c|}
\hline \multirow[t]{2}{*}{ Item } & \multirow{2}{*}{$\begin{array}{c}\text { 2003/04 } \\
\text { PRGF }\end{array}$} & \multicolumn{3}{|c|}{$2004 / 05$} & \multicolumn{3}{|c|}{$2005 / 06$} \\
\hline & & Low & $\begin{array}{l}\text { Base } \\
\text { Case }\end{array}$ & High & Low & $\begin{array}{l}\text { Base } \\
\text { Case }\end{array}$ & High \\
\hline Real GDP Growth (\%) & 6.7 & 4.0 & 6.4 & 6.9 & 4.0 & 6.1 & 7.0 \\
\hline GDP Deflator (\%) & 5.2 & 6.0 & 3.7 & 4.9 & 6.2 & 3.2 & 5.0 \\
\hline Inflation Rate & 5.5 & 5.2 & 3.0 & 2.8 & 5.7 & 3.0 & 3.0 \\
\hline GDP @ CMP & 64277 & 70095.7 & 71197 & 72188.4 & 76754.8 & 78177 & 81064.7 \\
\hline $\begin{array}{l}\text { Nominal GDP Growth } \\
(\%)\end{array}$ & 12.8 & 9.1 & 10.8 & 12.0 & 9.5 & 9.8 & 12.3 \\
\hline
\end{tabular}

\section{$\underline{\text { Low Case Scenario }}$}

Under the Low Scenario, real GDP is forecasted by assuming drought and/or external shocks to occur in both the outer projection years $(2004 / 05 \& 2005 / 06)$. This is expected to cause a reduction in agricultural output although the expansion of the extension programme and application of modern inputs are likely to bring about an increase in yield in non-drought prone areas. The access to land and water harvesting programmes currently underway are also expected to have a positive impact on agricultural output, thus slightly compensating the effect of the anticipated drought. That is why the possibility of negative real GDP growth is ruled out. A drought is also expected to have an impact on the activities of the sectors, with relatively strong linkages with the agriculture sector. Thus growth rates for small-scale \& cottage industries, trade, and transport \& communications are estimated by considering the low agricultural output in the projection years. Thus, overall GDP is projected to grow at about 4 percent in both forecast years. Inflation under the low scenario is projected at 5.2 and 5.7 percent, respectively. The GDP deflators for the two consecutive years (2004/05 and 2005/06) are projected at $\mathbf{6 . 0}$ and $\mathbf{6 . 2}$ percent, respectively. Thus, nominal GDP is projected to increase by $\mathbf{9 . 1}$ and $\mathbf{9 . 5}$ percent in 2004/05 and 2005/06, respectively (Table 6 above).

\subsubsection{Fiscal Implications of the Alternative Macro Scenarios}

As indicated above, for the 2003/04 FY, the fiscal implications of real GDP growth and prices are already reviewed and set in line with the agreement under the fifth PRGF review. Indicative targets are also set for the outer two years under the PRGF Program. What need to be assessed are the fiscal implications of the alternative (High and Low) scenarios for the outer two years.

\section{High Scenario}

Under this scenario, domestic revenue is projected to increase by about 29 and 16 percent during 2004/05 and 2005/06, respectively. Of this, the tax component is projected to increase by 33 and 18 percent during 2004/05 and 2005/06,respectively. The non-tax component is also projected to show a modest increase of about 14 and 6.0 percent during the two outer consecutive years, respectively. With in the tax component; direct taxes, domestic indirect taxes, and foreign trade taxes are expected to account for 40, 23 and 37 percent of tax revenue during 2004/05. Their relative share is projected to increase to 42,25 and 34 percent of total tax revenue during 2005/06. Non-tax revenues are projected to account for about 19.0 and 17.0 percent of domestic revenue during 2004/05 and 2005/06, respectively. Under this scenario, domestic revenue is projected at about 14 and 18 percent higher than that projected 
under the Baseline for 2004/05 and 2005/06, respectively. Domestic revenue is projected to reach 21.5 and 22.2 percent of GDP during 2004/05 and 2005/06, respectively. While tax revenues are projected to increase from 17.6 in 2004/05 to 18.5 percent of GDP in 2005/06 the non-tax component is expected to decline from 4.0 to 3.8 percent of GDP during the respective years. The decline in the relative share of the non-tax component is in line with the Government's tax reform agenda aimed at putting the domestic resource mobilization effort on a more sound and sustainable base: increasing reliance on productive economic activities as a basis for domestic revenue generation.

Under this scenario, notwithstanding the difficulties to predict external grants, the emergency relief component is projected to show a modest decline as it is expected to decline assuming that the overall economic environment would improve. However, still budget support /CPF grants is expected to show a modest increase even under the High Scenario. The details for the current fiscal year (the Program) and the two outer years are depicted in Table 7 below.

Under the High scenario, expenditure for the outer two years is projected taking in to consideration the government's overriding agenda of boosting poverty reducing spending over the coming two years given that 2004/05 is the last year of the SDPRP period and 2005/06 might also be the beginning of the second cycle of the SDPRP.

Under the high scenario, poverty reducing expenditures are projected taking in to consideration the projected increase in domestic revenue and rationalizing discretionary spending items. Defense spending is projected at 2.4 Billion Birr for both projection years (2004/05 \& 2005/06). Under the High Case, the increase in domestic revenue over the Base Line has been projected at over 1.9 and 2.9 Billion Birr in 2004/05 and 2005/06, respectively. This increase in the projected level of domestic revenue augmented by increases in projections of external project assistance and loans made based on existing commitments serve as basis for projected allocations across sectors with priority focus on poverty-oriented sectors. Under this scenario, it is worth noting that external grants (emergency relief and CPF/budget support) falls short of the Base Line (albeit by not a significant amount) for both projection years (Table 7).

Accordingly, total expenditure on poverty-oriented sectors is projected at about 58 and 64 percent of total expenditure and 18.5 and 20.1 percent of GDP at current market prices during 2004/05 and 2005/06, respectively. Under the Base Line, the relative spending levels on poverty-targeted sectors are almost the same as the High case. Defense spending declined from 3.7 percent of GDP in 2003/04(Program) to 3.2 percent and further to 2.8 percent of GDP in 2004/05 and 2005/06, respectively.

Under the high scenario, budget deficit including grants is projected at 5.6 and 3.8 percent of GDP at current market prices for the two consecutive projection years $(2004 / 05$ and 2005/06), respectively. The deficit is to be financed through net external borrowing of 3618 million Birr (4.8\% of GDP) with a financing gap indicated in Table 7 below as "net domestic bank and non-bank borrowing" of 473 million Birr (0.6\% of GDP) for 2004/05. For 2005/06, net external financing and financing gap (net) indicated in Table 7 below as "net domestic bank and non-bank borrowing" are projected at 2.8 and 0.8 percent of GDP, respectively. Under the Base Line, net external finance is projected at 4.8 and 3.1 percent of GDP for 2004/05 and 2005/06,respectively. Compared to the High case, the Base Case shows a tendency to overstate external finance in both projection years. 


\section{$\underline{\text { Low Scenario }}$}

Under this scenario, domestic revenue is projected to reach 13.3 and 14.7 Billion Birr during 2004/05 and 2005/06, respectively. With in the tax component direct taxes, domestic indirect taxes, and foreign trade taxes are expected to account for 40, 24 and 37 percent of tax revenue during 2004/05 and 2005/06, respectively. Their average relative share is projected to increase to 37,24 and 39 percent of total tax revenue during 2005/06.

The non-tax component is also projected to reach about 2.8 billion Birr each during the two outer consecutive years, respectively. Non-tax revenues are projected to account for 21 and 19 percent of domestic revenue during 2004/05 and 2005/06, respectively. Under this scenario, domestic revenue is projected at 7.3 and 7.5 percent lower than that projected under the Baseline for 2004/05 and 2005/06, respectively.

Under the Low Case, domestic revenue including grants is projected at about 18.2 and 19.8 billion Birr during 2004/05 and 2005/06, respectively. Under the Base Line, the projection for the respective years amounted to about 18.5 and 19.9 Billion Birr. Of this, under the Low case, the domestic component is projected to reach 13.3 and 14.7 billion Birr during 2004/05 and 2005/06,respectively. As indicated, the projected deviation of the Low case from the Base Line in terms of total resources (domestic revenue plus grants) seems to be narrow as the shortfall in domestic revenue in the Low case is expected in large part to be offset by the assumed significant increase in external grants largely owing to envisaged relief emergency assistance.

On the expenditure side (under the low scenario), expenditure on poverty-targeted sectors is projected consistent with domestic revenue shortfall compared to the level of domestic revenue projected under the PRGF Program while as much as possible protecting spending allocation for poverty-oriented sectors. Defense spending is being maintained at 2.4 Billion Birr in line with the PRGF Program for both projection years (2004/05 \& 2005/06). Spending on discretionary items is also rationalized. The shortfall in domestic revenue against the Base Line has been projected at over 1.03 and 1.19 Billion Birr in 2004/05 and 2005/06, respectively. This shortfall in the projected level of domestic revenue is to be partially compensated by increases in projection of external grants made based on existing commitments serves as basis for projected allocations across sectors with priority focus on poverty-oriented sectors. Under this scenario, it is worth noting that external grants (largely emergency relief and CPF/budget support) are projected to increase over the Base Line level for both projection years (Table 7). External grants under the Base Line is projected at 6 and 5.2 percent of GDP for 2004/05 and 2005/06,respectivel while external grants is projected at 7 and 6.6 percent of GDP for the respective years under the Low Scenario.

Poverty reduction being the government's overriding priority agenda, spending on povertyoriented sectors is not going to be compromised under even difficult circumstances. This is also what was witnessed during the 2002/03 fiscal year where spending on poverty-oriented sectors even showed an increase over the preceding fiscal year (2001/02).

Under the Low scenario, budget deficit including grants is projected at 6.2 and 4.4 percent of GDP at current market prices for the two consecutive projection years (2004/05 and 2005/06), respectively. The deficit is to be financed through net external borrowing of 3618 
million Birr (5.2\% of GDP) and financing gap indicated in Table 7 below as "net domestic bank and non-bank borrowing” of 634 million Birr (0.9\% of GDP) for 2004/05. For 2005/06, net external financing and financing gap are projected at 3.4 and 0.9 percent of GDP, respectively. Under the Base Line, net external finance is projected at 5.1 and 3.3 percent of GDP for 2004/05 and 2005/06, respectively.

In conclusion, it is worth noting the following points in connection with the line item "Net Domestic borrowing". In regard to the outer two years (2004/05 and 2005/06) for both the Low and High scenarios, the "net domestic bank borrowing" figures in Table 7 for 2004/05 and 2005/06 do not necessarily represent intended (planned) levels of domestic bank and non-bank borrowing, rather a Financing Gap, given the limitation of firm data on envisaged multi-annual external finance disbursement plans. As is already indicated, the level of external finance is based on existing commitments, which are to be firmed up as time goes. Thus, the figures against the line item "Domestic Net" for the 2004/05 and 2005/06 strictly represent financing gap (net) rather than net domestic bank and non-bank borrowing. The line item "net domestic bank and non-bank borrowing" strictly applies only for the 2003/04 FY (Table 7) in line with the Program (PRGF).

The details of the fiscal implications (revenue, expenditure, and financing) of the High, Baseline and the Low scenarios for 2004/05, 2005/06 are summarized in Table 7 below. 
Table 7: Summary of Government Finance Forecast (Low, Base Line, and High Scenarios), 2003/04-2005/06

\begin{tabular}{|c|c|c|c|c|c|c|c|}
\hline & & & & & Values i & in Million Bi & \\
\hline Ethiopian fiscal year & 1996 & & 1997 & & & 1998 & \\
\hline Fiscal year ending July 7 & $2003 / 04$ & & $2004 / 05$ & & & $2005 / 06$ & \\
\hline & $\begin{array}{c}\text { Revised } \\
\text { PRGF } \\
\text { Program } \\
\end{array}$ & Low & $\begin{array}{c}\text { Revised } \\
\text { Projections } \\
\text { Baseline }\end{array}$ & High & Low & $\begin{array}{l}\text { Revised } \\
\text { Projections } \\
\text { Baseline }\end{array}$ & High \\
\hline Total Revenue and Grants & 17084 & 18131 & 18585 & 20393 & 19750 & 200142 & 22716 \\
\hline Revenue & 12542 & 13272 & 14323 & 16157 & 14679 & 159281 & 18730 \\
\hline Tax revenue (inc measures) & 9932 & 10482 & 11511 & 13172 & 11830 & 129631 & 15555 \\
\hline Direct taxes & 3673 & 4165 & 4282 & 5287 & 4434 & 4873 & 6531 \\
\hline Indirect taxes & 6259 & 6317 & 7230 & 7885 & 7396 & 8090 & 9024 \\
\hline Domestic indirect taxes & 2150 & 2524 & 2807 & 3088 & 2805 & 3253 & 3829 \\
\hline Import duties \& taxes & 4109 & 3793 & 4423 & 4797 & 4591 & 4838 & 5195 \\
\hline Export taxes & 0 & 0 & 0 & 0 & 0 & 0 & 0 \\
\hline Non-tax revenue & 2610 & 2790 & 2812 & 2985 & 2849 & 2965 & 3175 \\
\hline Grants & 4542 & 4859 & 4262 & 4236 & 5071 & 4086 & 3986 \\
\hline Total Expenditure & 21093 & 21666 & 218362 & 23867 & 22903 & 228092 & 25769 \\
\hline Current expenditure & 12752 & 13511 & 13097 & 14088 & 14091 & 133791 & 14830 \\
\hline Defense & 2400 & 2400 & 2400 & 2400 & 2400 & 2400 & 2400 \\
\hline Poverty-targeted expenditure & 4446 & 4845 & 4893 & 5415 & 5235 & 5338 & 6186 \\
\hline Education & 2513 & 2615 & 2700 & 2877 & 3026 & 3100 & 3315 \\
\hline Health & 711 & 825 & 819 & 898 & 815 & 832 & 1040 \\
\hline Agriculture & 788 & 918 & 849 & 1009 & 907 & 832 & 1070 \\
\hline Water & 250 & 272 & 315 & 349 & 278 & 358 & 415 \\
\hline Roads & 183 & 215 & 210 & 282 & 209 & 216 & 346 \\
\hline Interest payments & 1447 & 1526 & 1509 & 1526 & 1531 & 1564 & 1531 \\
\hline Domestic interest & 773 & 768 & 818 & 768 & 762 & 864 & 762 \\
\hline External interest & 675 & 758 & 691 & 758 & 769 & 699 & 769 \\
\hline Emergency assistance (food and other emergency aid) & 874 & 1500 & 902 & 877 & 1900 & 914 & 815 \\
\hline Others & 3583 & 3241 & 3393 & 3871 & 3025 & 3164 & 3897 \\
\hline Capital expenditure & 8341 & 8154 & 8740 & 9779 & 8812 & 94301 & 10939 \\
\hline o/w: Poverty targeted expenditures & 6841 & 7225 & 7550 & 8485 & 8010 & 85731 & 10410 \\
\hline Education & 898 & 949 & 991 & 1304 & 1035 & 1108 & 1515 \\
\hline Health & 629 & 664 & 694 & 899 & 820 & 878 & 1300 \\
\hline Agriculture & 1978 & 2089 & 2183 & 2332 & 2360 & 2526 & 2840 \\
\hline Water & 1036 & 1094 & 1143 & 1291 & 1275 & 1365 & 1755 \\
\hline Roads & 2301 & 2430 & 2539 & 2660 & 2520 & 2697 & 3000 \\
\hline Special programs & 535 & 767 & 767 & 767 & 217 & 217 & 217 \\
\hline Overall balance including grants (excl. special programs) & -4009 & -3535 & -3251 & -3474 & -3153 & $-2795-$ & -3053 \\
\hline Overall balance excluding grants (excl. special programs) & -8551 & -8394 & -7513 & -7710 & -8224 & $-6881-$ & -7039 \\
\hline Overall balance including grants & -4544 & -4302 & -4019 & -4241 & -3370 & $-3012-$ & -3270 \\
\hline Overall balance excluding grants & -9086 & -9161 & -8281 & -8477 & -8441 & $-7098-$ & -7256 \\
\hline Financing & 4545 & 4302 & 4019 & 4241 & 3370 & 3012 & 3270 \\
\hline External (net) & 3283 & 3618 & 3618 & 3618 & 2613 & 2613 & 2613 \\
\hline Gross borrowing & 3336 & 3599 & 3599 & 3599 & 2647 & 2647 & 2647 \\
\hline HIPC relief & 695 & 815 & 815 & 815 & 822 & 822 & 822 \\
\hline Amortization paid & 748 & 796 & 796 & 796 & 856 & 856 & 856 \\
\hline Domestic(net) & 1162 & 634 & 300 & 473 & 707 & 300 & $\mathbf{5 0 7}$ \\
\hline Privatization & 100 & $\mathbf{5 0}$ & 100 & 150 & $\mathbf{5 0}$ & 100 & 150 \\
\hline Other and residual & $\mathbf{0}$ & $\mathbf{0}$ & $\mathbf{0}$ & $\mathbf{0}$ & $\mathbf{0}$ & $\mathbf{0}$ & $\mathbf{0}$ \\
\hline Memorandum item & & & & & & & \\
\hline GDP at current market price & 64277 & 70096 & 711977 & 75168 & 76755 & 781778 & 84415 \\
\hline
\end{tabular}




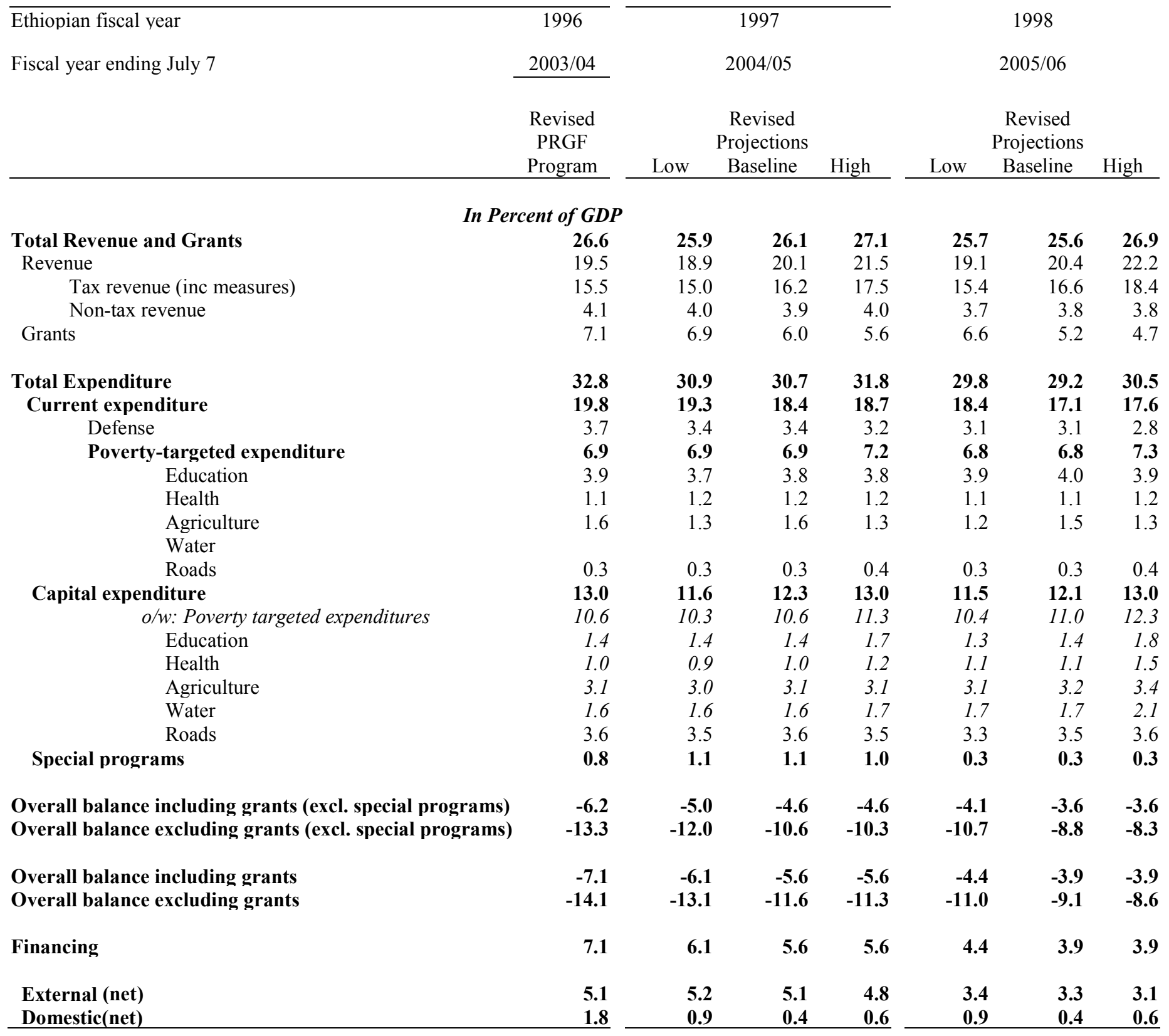

Note:- Under the low scenario, average real GDP growth of 4 percent is assumed for both 2004/05 \& 2005/06 fiscal years. Under such a scenario, inflation rate projected at 5.2 \& 5.7 percent for these years respectively is superimposed on the real GDP growth for both years to arrive at nominal GDP at market price by taking the nominal GDP projected under the revised PRGF for 2003/04 as a base. 


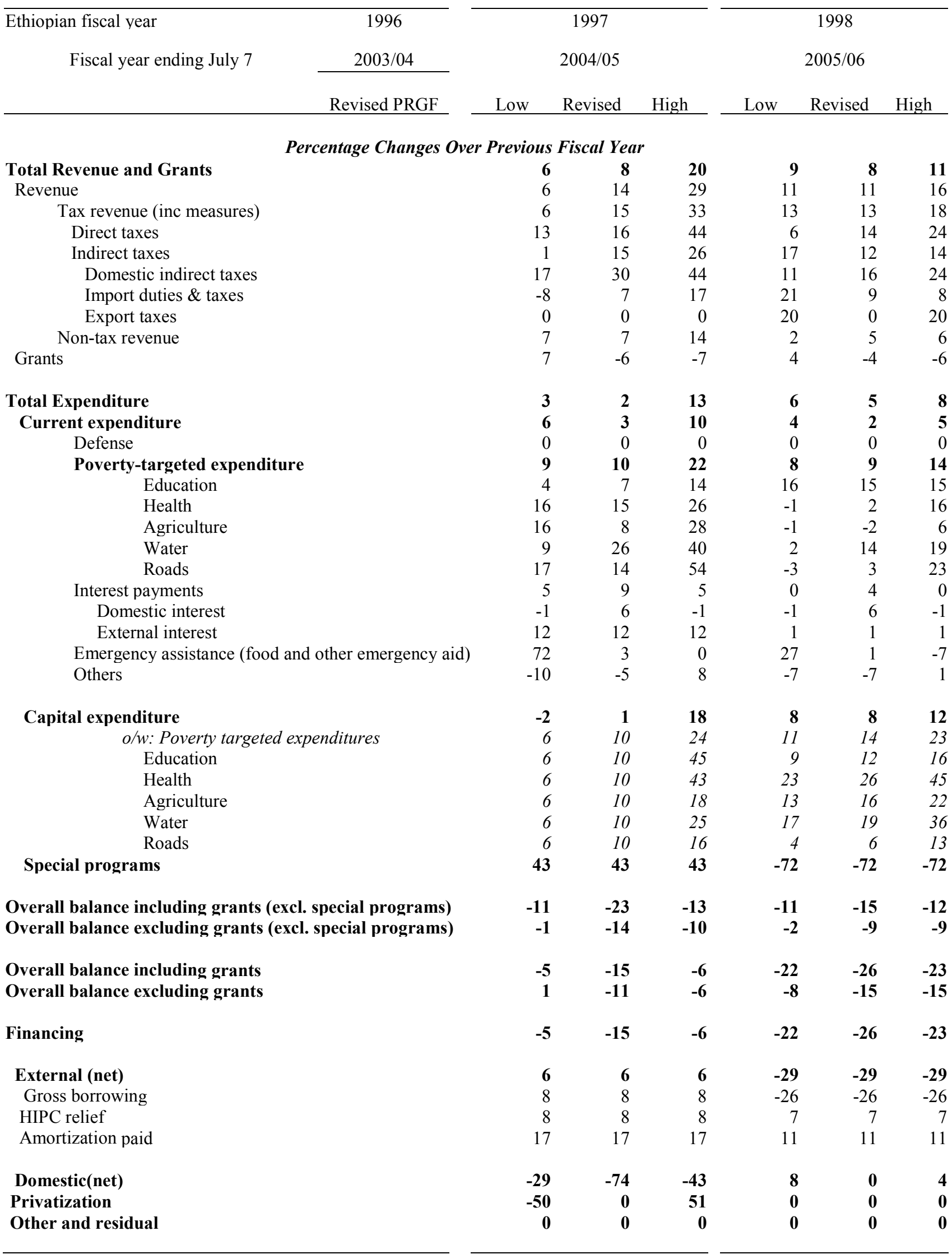




\subsubsection{Implications of Alternative Scenarios on SDPRP Financing}

In the context of Ethiopia, the war on poverty is multi-thronged and needs to be carried out at all possible fronts. Poverty reduction strategies such as the SDPRP serve as vehicles to achieving the MDGs. As indicated in the SDPRP targets set across key poverty-oriented sectors are consistent with MDGs. All targets in the MDGs have equal weight and urgency in the Ethiopian context. It is difficult to separate and make emphasis on one or the other. In fact, there is so much interdependence that the total is greater than the sum of the individual goals.

Table 8: Projected Poverty-targeted Allocation as a \% of GDP

\begin{tabular}{|l|l|l|l|l|l|l|}
\hline \multirow{2}{*}{ Sectors } & \multicolumn{2}{|l|}{$2004 / 05$} & \multicolumn{2}{l|}{$2005 / 06$} & High \\
\cline { 2 - 7 } & Low & $\begin{array}{l}\text { Base } \\
\text { Line }\end{array}$ & High & Low & $\begin{array}{l}\text { Base } \\
\text { Line }\end{array}$ & H. \\
\hline $\begin{array}{l}\text { Agriculture and Food } \\
\text { Security }\end{array}$ & 4.3 & 4.3 & 4.3 & 4.3 & 4.3 & 4.7 \\
\hline Water & 2.0 & 2.0 & 2.0 & 2.1 & 2.2 & 2.6 \\
\hline Roads & 3.8 & 3.9 & 3.9 & 3.6 & 3.8 & 4.0 \\
\hline Education & 5.2 & 5.2 & 5.5 & 5.4 & 5.4 & 5.7 \\
\hline Health & 2.2 & 2.2 & 2.4 & 2.2 & 2.2 & 2.7 \\
\hline Total & 17.5 & 17.6 & 18.1 & 17.6 & 17.9 & 19.7 \\
\hline
\end{tabular}

The fact that spending margins on poverty-oriented across the three scenarios (Table 8), particularly for 2004/05, is the reflection of the Government's determined intention coupled with the understanding among development partners that each of the core sectors are equally important to addressing the poverty issue in all its dimensions. The core sectors would be protected under any environment of budget constraint. This has been witnessed during the budget allocations trends in the recent past (the conflict years of $1998 / 99$ and 1999/2000) and the drought year of 2002/03. This does not mean that these achievements were with out costs given the lag in disbursements from external finance. The external debt burden is also another pressing factor.

Table 7 above depicts financing requirement under both the High and Low scenarios for the two consecutive projection years. The financing requirement measured as a ratio to GDP is larger under the Low Scenario than both the Base Line and the High Scenarios. This is evident as revenues are expected to be lower under the Low Scenario than the High Scenario while spending levels on key poverty-oriented sectors are as much as possible protected even under the Low Scenario. Under the Low Scenario, fiscal deficit including grants (according to existing commitments) are projected at 6.2 and 4.4 percent of GDP for 2004/05 and 2005/06, respectively. Under the High Scenario, the deficit levels are projected at 5.6 and 3.8 percent of GDP, respectively for the corresponding years. During 2004/05, the deficit level including grants is projected to widen by about 0.9 percentage points under the Low Scenario and by 0.3 percentage points under the High Scenario compared to the deficit level under the PRGF Program (5.3\% of GDP).

The 2004/05 FY is the last year of the SDPRP period. As indicated above, during this year, under the Low scenario, fiscal deficit including grants is projected at $6.2 \%$ of GDP. For this year, the level of deficit is to be financed through net external borrowing of 3618 million Birr and net domestic bank and non-bank borrowing of 634 million Birr. 
For the same year (2004/05), under the High Scenario, fiscal deficit including grants is projected at $5.6 \%$ of GDP. For the same fiscal year (the last year of the SDPRP), under the High Scenario, the deficit is to be financed through net external borrowing of 3618 million Birr and net domestic bank and non-bank borrowing of 473 million Birr. Net external financing happens to be the same both under the High and Low scenarios as the levels in both fiscal years are based on existing commitments as is already indicated.

However, for 2004/05 under both scenarios, the levels of domestic bank financing have exceeded the "zero domestic bank and non-bank borrowing" under the Base Line. This may raise concerns for macro stability. Alternatively, reducing expenditures will affect the targets set in the SDPRP, and hence growth and poverty reduction. One should not see this in terms of achieving a selected set of targets such as those in the HIPC triggers. One has to see poverty in all its dimensions and in all-encompassing manner. Accordingly, increased flexible external support will help to mitigate the problem.

In summary, Ethiopia's challenge to meet all the targets set in the SDPRP and MDGs is understandably not easy. Several of the second-generation reforms on the home front and increased commitment by the international community may help realize the objectives set in the SDPRP and hence MDGs. 


\subsubsection{The 2003/04 Budget}

Ethiopia's PRSP (the SDPRP) has already gone in to one year of implementation and the 2003/04 fiscal year is the second year in to the implementation of this comprehensive Program. Poverty-oriented sectors have been given due emphasis during the formulation of the MEFF and the preparation of the 2003/04 budget. The basis for 2003/04 budget is the 2003/04-2005/06 macroeconomic and fiscal Framework (MEFF). One of the new developments during the 2003/04 fiscal year is the new dimension and enhanced emphasis given to food security. The figures discussed below are based on the 2003/04 budget.

\section{Revenue}

During the fiscal year 2003/04, general government revenue and grants is budgeted at $\mathbf{1 7 8 1 7}$ million Birr. Out of the total general government revenue and grants, some Birr 13140 million (74 percent) is from domestic sources and the balance Birr 4677 million (26 percent) is from external grants.

\section{Expenditure}

Total general government expenditure during fiscal year 2003/04 is budgeted at Birr 22122 million. Of which Birr 13364 million (60 percent) is recurrent expenditure and Birr 8114 (37 percent) capital expenditure.

Of the total expenditure (from all sources) Birr 12,097 million is allocated for povertytargeted sectors with Education, Roads, Agriculture and food security, Health, and Water budgeted at Birr 3932.2, 3150.5, 2490,4, 1537.9, and 965.9 million respectively. With in education, the recurrent component accounted for 68 percent of the total budget for education (from all sources) while the residual is accounted for by the capital component. With regard to roads the capital component accounted for the lion's share of the total budget (97 percent). In 2003/04, total budget allocation to poverty-targeted sectors increased by 17 percent compared to fiscal years 2002/03 budget. In the 2003/04 budget, agriculture and food security, roads, health, and water in that order recorded the highest growth over the 2002/03 budget(Table 9 below)

The significant increase in spending on agriculture and food security (over 46 percent) is the reflection of the renewed emphasis on food security as witnessed by the increase in the food security budget (specific grants to regions) from 150 million Birr in 2002/03 to 1 billion Birr in 2003/04 budget and the recent developments in the context of the New Coalition for Food Security. Such increases in budget allocation to poverty-oriented sectors such as agriculture and food security, roads, health and water is a reflection of the continued pronounced focus by the government on those sectors. Table 9 below depicts the details on budget allocation to poverty-targeted sectors. 
Table 9: Sectoral Distribution of Poverty Targeted Expenditure in the 2003/04 Budget ${ }^{7}$

Values in Million Birr

\begin{tabular}{|c|c|c|c|c|}
\hline \multirow[t]{2}{*}{ Sectors } & \multicolumn{2}{|c|}{$2002 / 03$} & \multicolumn{2}{|c|}{$2003 / 04$} \\
\hline & Budget & Pre. Actual & Budget & $\begin{array}{c}\% \text { Change } \\
\text { Over 2002/03 } \\
\text { Budget }(\%)\end{array}$ \\
\hline Agriculture and Food Security & 1748.1 & 1453.3 & 2490.4 & 42.5 \\
\hline Water & 887.7 & 585.9 & 965.9 & 8.8 \\
\hline Roads & 2449.7 & 1899.7 & 3105.5 & 28.6 \\
\hline Education & 3863.5 & 3174.8 & 3952.2 & 2.3 \\
\hline Health & 1390.9 & 913.9 & 1537.9 & 10.6 \\
\hline Total & 10339.9 & 8027.5 & 12096.9 & 17.0 \\
\hline
\end{tabular}

During fiscal year 2003/04, total regional transfer (both recurrent and capital) has been budgeted at 5055.8 million Birr. Compared to fiscal year 2002/03 the regional transfer (from treasury) during 2003/04 FY increased by about 12 percent.

\section{Food Security Budget}

During the fiscal year 2003/04 1 billion Birr budget has been apportioned across the regional states for the food security. To address the problem of food insecurity in the long run in a sustainable way, the Government has significantly increased (more than five fold) the resource allocated for food security programs for the 2003/04 fiscal year. Although food security is a federal Government Program, the implementers are regional states.

\section{Budget Deficit and Financing During 2003/04}

During the fiscal year 2003/04, General Government total revenue including grants amounted to Birr 17817 million while total expenditure (both recurrent and capital) excluding special program is budgeted to be Birr 21478 million. Thus, an over all fiscal deficit of Birr 4305 million is to be observed. This overall fiscal deficit will be financed through net external borrowing of Birr 3041 million, net domestic borrowing of Birr 1162 million and privatisation receipts of Birr 100 million.

\footnotetext{
${ }^{7}$ From all sources (treasury, loan and assistance)
} 
6.3. Gaps in SDPRP Financing: Deviations of Alternative Scenarios from the Base Line

According to Table 7 above, as per the 2003/04 budget allocations (the Program) as well as the projected allocations for the outer two years for alternative scenarios, all consistently showed that Education followed by Agriculture and Food Security, Roads, Health, and Water in that order accounted for the bulk of pro-poor spending. The shift in the order of importance from the original SDPRP program costs in which allocation for Agriculture and Food security (since the 2003/04 Budget) surpass that of roads (which used to be second following Education) is the reflection of the renewed focus on food security in the context of the New Coalition for Food Security.

Table 10: Projected Poverty-oriented Allocations and Deviations from the base Line (Million Birr)

\begin{tabular}{|l|c|c|l|l|}
\hline \multirow{2}{*}{ Sectors } & \multicolumn{2}{|c|}{$\mathbf{2 0 0 4 / 0 5}$} & \multicolumn{2}{c|}{$\mathbf{2 0 0 5 / 0 6}$} \\
\cline { 2 - 5 } & $\begin{array}{c}\text { Low Case } \\
\text { (Shortfall) }\end{array}$ & $\begin{array}{c}\text { High Case } \\
\text { (In Excess) }\end{array}$ & $\begin{array}{l}\text { Low Case } \\
\text { (Shortfall) }\end{array}$ & $\begin{array}{c}\text { High Case } \\
\text { (In Excess) }\end{array}$ \\
\hline Agriculture and Food Security & -26 & 308 & -91 & 552 \\
\hline Water & -92 & 182 & -170 & 447 \\
\hline Road & -104 & 193 & -184 & 433 \\
\hline Education & -128 & 489 & -147 & 622 \\
\hline Health & -24 & 284 & -75 & 630 \\
\hline Total & $\mathbf{- 3 7 3}$ & $\mathbf{1 4 5 7}$ & $\mathbf{- 6 6 6}$ & $\mathbf{2 6 8 4}$ \\
\hline
\end{tabular}

As indicated in Table 10 above, for 2004/05, which is the last year of the SDPRP, allocation on poverty-oriented sectors is projected to fall short of the Base Line by about 373 million Birr. This is equivalent to over 0.5 percent of GDP under the Low Scenario. The bulk of the short fall in projected allocation is attributed to the capital expenditure component of poverty-oriented sectors with implications on growth and poverty reduction. More over, with in sectors, education, roads, and water in that order face the highest shortfalls in projected allocations as shown in Table 10 above. Under the Low Scenario, shortfalls in allocation for poverty-oriented sectors are projected at 666 Million Birr (about 0.9\% of GDP) during 2005/06 with almost the same pattern of spending short falls across sectors. The capital component is again significantly affected by the projected short falls from the Base Line.

For 2004/05, with regard to the High Case, projected allocation overall exceeds the Base Line level by about 1.5 Billion Birr (1.7\% of GDP). Under this Scenario, the sectors that are likely to benefit from the projected higher allocation in the order of their importance are Education, Agriculture and Food Security, Health, and Roads as indicated in Table 10 above. For 2005/06, the excess of allocation over the Base Line is projected at about 2.7 Billion Birr (3.2\% of GDP). The sectors that are likely to benefit from the projected higher allocation during this year in the order of their importance are Health, Education, Agriculture and Food Security, and Water (Table 10).

Given the government's overriding agenda of poverty reduction and ultimate eradication via achieving fast and sustainable growth and improved human development, the High 
case needs to be seen as the least minimum required to achieving the objectives and targets set in the SDPRP and hence MDGs. A recent MDG study jointly undertaken by the Government and the United Nations Country Team in Ethiopia entitled "Millennium Development Goals (MDGs): Challenges and Prospects for Ethiopia" indicated that the costing in the original SDPRP Document (even the High Case) is considered to be on the low side in the context of achieving the goals set in the MDGs. The study indicated that Ethiopia needs significant increase in external support over the next decades or so to be able to meet the targets set in MDGs.

\subsection{Managing the Gaps between Program Costs and Available Finance}

As discussed above there is gap between available resources and program costs. The macroeconomic and fiscal framework and the annual budget preparation exercises are instruments used to manage the gap. This is what the government did for FY 2002/03 as well as the current fiscal year (2003/04). High priority is accorded to poverty-oriented sectors compared to other expenditures.

As discussed in the SDPRP Prioritization among Poverty oriented sectors is not an easy task since the nature of poverty is multidimensional requiring multidimensional response. In Ethiopia all key poverty oriented sectors are equally important for achieving rapid growth and poverty reduction. However, prioritization of activities can be made within each sector taking the opportunity offered by the annual budget preparation exercise.

Further, the government will take necessary effort to coordinate the efforts of NGOs since they are already engaged in key poverty oriented sectors. The devolution to woreda also helps to mobilize community contributions to activities in education, health, water, and rural roads. Government is also introducing mechanisms for cost sharing for the services in higher education and health. 


\section{Overview of Performances of Key Sectors}

\subsection{Food Security}

In regard to the Food Insecurity problem in Ethiopia, a complex combination of factors has resulted in sharply increased levels of vulnerability to food insecurity for a great number of Ethiopians. These factors include: changes in climate leading to more frequent droughts, widespread land degradation, limited alternative income alternatives and opportunities, increased population pressure, poor market integration, limited access to basic services, inputs, credit and information, technological issues; and issues having to do with national policies and implementation constraints. The extent of food insecurity has become alarming in recent years. About 45 percent of the population is affected during drought years. This chronic situation is frequently aggravated by unexpected shocks such as drought. Even during normal years, on average, over five million people have been affected by drought related factors.

With its rural population highly dependent on agricultural production, there is an immediate linkage between crop failures and household food deficit. The absence of off-farm income opportunities coupled with the unpredictability of emergency food aid assistance has led to escalating asset depletion and increasing levels of destitution.

The severity of the chronic food insecurity crisis faced by millions of Ethiopians calls for renewed commitment from all and a joining of hands with the Government to deal with the situation on an emergency footing to give it a sustainable solution.

\section{Steps towards Addressing the Food Security Crisis}

Major steps have been taken by the Government recently to create a supportive and enabling policy environment to address these food insecurity challenges.

The overarching policy framework for the food security program is the Sustainable Development Poverty Reduction Program (SDPRP) that has focused on agriculture being the means of livelihood for over 85 percent of the population, as well as being the primary source of surplus to fuel growth in other sectors. Within the context of the SDPRP, the Rural Development policies and strategies aim at transforming agriculture from subsistence to small-scale commercial farming.

The Federal Food Security Strategy is supportive of this approach, resting on three "pillars": increasing the supply of food, improving access to food, and strengthening Ethiopia's emergency response capabilities. A vital incentive for farmers to invest in their land and improve production are the Land Administration policies that aim to offer individual households greater security over land through a certification process that guarantees land use and transfer rights.

Policies that promote improvements in governance, decentralization of decision-making and greater local empowerment also create an enabling environment for this food security program. To strengthen these efforts, since 1997, the Government of Ethiopia has been undertaking a program of civil service reform that aims to improve service delivery through how it manages its own human and financial resources, how it sets and monitors strategic priorities, and how it maintains ethical standards. 
This emphasis on improved Government service delivery led to the National Capacity Building Program, which aims to develop institutional and human resource capacities in all sectors of the economy. This is manifested through the Agricultural Technical Vocational Education and Training (Agri-TVET) program, with an enrolment capacity of 30,000 students who will graduate to improve the functioning of the extension system by being teachers of Development Agents (Das).

Two other national policy frameworks are critical for the food security program's success: the National Policy for Disaster Prevention and Management (NPDPM) and the National Population Policy. Central to the NPDPM are social safety nets, which are intended to provide families a cushion against food insecurity while at the same time creating a foundation of productive assets within the community. Actions defined by the National Population Policy to reduce population pressure tackle a key underlying cause of the food insecurity problem in Ethiopia.

\section{Food Security Program: Purpose, Goal and Objectives}

The purpose of the program is to drastically reduce food insecurity faced by vulnerable Ethiopian households. Its five-year goal is to attain food security for five million chronically food insecure people, while, at the same time, improving and sustaining the overall food security of an additional ten million people. Four inter-linked objectives have been defined in order to achieve these goals:

a) Availability of food increased through improved crop and livestock production;

b) Access to food increased through expanding agriculture and nonagriculture incomes;

c) Preventative and curative health services promoted;

d) Provide access to land through voluntary resettlement for up to 440,000 chronically food insecure households.

These objectives are linked together via the implementation modalities they will adopt. The use of safety nets as an approach to improving food access through conditional transfers supports activities in both objectives (a) and (b). The first three objectives are linked to the major capacity building effort that needs to be urgently scaled-up and sustained. Further, all three objectives are inter-linked by the enhanced extension system that will support the community-based, multi-annual planning approach which, among other things, aims to mainstream health issues. The fourth objective is also supportive of the overall goal.

Working in conjunction, the first three objectives aim to "push" outwards the ring of poverty that currently constrains household food and livelihood security. The program aims to improve availability and access to food while also creating the favorable health conditions necessary for individuals and families to utilize food effectively.

The severity of food insecurity is too serious to act immediately. It aims for significant coverage and impact by dealing effectively with the underlying causes of food insecurity. It recognizes that donors or even the Government will not provide the solutions to food insecurity. Social mobilization is a critical element to exhaustively use resources of the rural community. 
Due consideration is given to the labor and land of the farmers as the basis for the development and donors resource will supplement the effort of the food in-secured households to sustainably move out of the root causes of poverty.

With good design (less restrictive in the quality and quantity of resource flow) and simplicity of the technological package, the beneficiary communities do not have significant capacity problem in program implementation. Capacity limitation around the high level technicians and development agents is given special focus in the context of rural development.

In addressing the challenges of food insecurity in Ethiopia in a more coordinated and strengthened manner, a high level consultative process has been undertaken to strengthen the partnership between the government and its development partners. A high level workshop was organized by the Government on 11-12 June 2003 to search for a lasting solution to the issue of chronic food insecurity. The remarkable convergence of views that have come out of this Workshop resulted in the formation of the New Coalition for Food Security determined to "do business differently" while defining concrete steps to lead the country towards enhanced food security. The Coalition established a Technical Group comprising of specialists representing both government and development partners who were given the mandate to articulate the Program. A draft of this proposal was discussed and enhanced during the second high level workshop held on 26-27 September 2003 that was attended by H.E. the Prime Minister and other senior government officials, ambassadors, donor, UN and NGO representatives, members of the private sector, and civil society. The revised proposal under consideration now reflects the high level commitment to the process.

The final program is discussed at the partnership Event for Livelihood and Food Security for Ethiopia held during December 1-2, 2003 various stakeholders-government, donors, NGOs participated to review the program and agree on the next steps.

This program is designed around the farmer aimed at effectively and efficiently utilizing his or her decisive resource: land and labor. The aim of this new and more coordinated approach is to create an enabling environment to realize these underutilized capacities and potentials, allowing communities and individuals to better employ these resources to improve food security. Other actors: NGOs, private sector, and donors will play complementary role to enhance the effectiveness of the resources of the farmer.

According to the Action Plan of the New Coalition for Food Security, regional consultation events and woreda awareness creation efforts are actions scheduled in the very short-run. Other areas identified by the September 26-27 2003 workshop as matters of great urgency include, among others:

$>$ Devising mechanisms for stabilizing grain markets in the face of the upcoming bumper harvest;

$>$ Addressing risk and vulnerability in line with the New Approach to Food Security;

$>$ Finding appropriate mechanisms for multi-annual multi-agency funding of safety nets and institutional arrangements for its implementation.

The action plan has also indicated the need for strengthening and building up capacity of local administrations to work effectively and efficiently with communities rather than creating parallel institutions for the implementation of the program. 
The total estimated financial resource required for the implementation of this New Approach to food security amounted to about ETB 26 Billion (USD 3 Billion). Of this, the Resettlement cost is estimated at about ETB 2 Billion (approximately USD 217 Million) or about 7 percent of the overall program cost. Budget required undertaking non-resettlement activities are estimated at about ETB 22 Billion (or USD 2.5 Billion) including interventions to enhance food availability, access to food, improved health, nutrition, water supply and sanitation. This amount also includes resources for the capacity building, monitoring and evaluation and administration.

Table 10: Trends in Public Spending ${ }^{8}$ on Agriculture \& Food Security,

Value in Million Birr

\begin{tabular}{|c|c|c|c|c|c|}
\hline Item & $2001 / 02$ & $\begin{array}{c}2002 / 03 \\
\text { Pre. Actual }\end{array}$ & $\begin{array}{l}2003 / 04 \\
\text { Budget }\end{array}$ & $\begin{array}{c}\% \\
\text { Change }\end{array}$ & $\begin{array}{c}\% \\
\text { Change }\end{array}$ \\
\hline 1 & 2 & 3 & 4 & $5=3 / 2$ & $6=4 / 3$ \\
\hline Recurrent & 569.8 & 600.0 & 626.5 & 5.3 & 4.4 \\
\hline Capital & 792.6 & 853.3 & 1931.8 & -3.8 & 153.3 \\
\hline Total & 1362.4 & 1453.3 & 2558.3 & 0.02 & 87.7 \\
\hline Total Public Spending & 17651.5 & 18137.1 & 23448.5 & & \\
\hline $\begin{array}{l}\text { Agriculture spending as \% of } \\
\text { Total }\end{array}$ & 7.7 & 8.0 & 10.9 & & \\
\hline \multicolumn{6}{|l|}{ Per Capita (Birr) } \\
\hline Recurrent & 8.6 & 8.8 & 8.9 & 2.3 & 1.1 \\
\hline Capital & 12.0 & 12.5 & 27.6 & -6.7 & 146.4 \\
\hline Total & 20.6 & 21.3 & 36.5 & 0.0 & 82.5 \\
\hline Mid Year Population (Million) & 66.2 & 68.2 & 70.1 & 3.0 & 2.8 \\
\hline
\end{tabular}

Source: MOFED

Out of the total budget allocated for agriculture and food security, a total amount of Birr 1362.7 million was utilized during 2002/03.

The actual expenditure during 2002/03 didn't show change compared to the performance of $2001 / 02$. The total budget allocated for the sector increased by 87.7 per cent compared to 2002/03 actual expenditure and amounted Birr 2558.3 million in 2003/04 (Table 10).

\subsection{Pastoral Development}

As indicated in Sustainable Development and Poverty Reduction Program paper major socioeconomic constraints identified in pastoral development are ecological constraints, poor facilities, weak institutional support and lack of clarity of vision and strategy for pastoral development. It is also indicated that in the past "interventions were following a piecemeal development approach and development failed to be sustainable with continues deterioration and decline in the life and well being of the pastoral society". Therefore, the means for sustainable development of these areas now is a holistic and integrated development approach. The necessity of grass-root participation in the design and implementation phase

\footnotetext{
${ }^{8}$ Public spending for all years and all sectors covers all sources: treasury, external loan, and external assistance
} 
of development programs is also emphasized. It is recognized that sustainable development and radical transformation of the livelihood of the pastoral community could be achieved through a step-by-step and voluntary sedentarization of the pastoralists.

Therefore, in line with the stated objectives and strategies the technical interventions in pastoral development during last year are: as follows.

\section{Pastoral Community Development and Good Governance Policy}

A conference, which aims at sensitizing people on government policy on pastoral community development and good governance, was held at Dire Dawa. The conference was attended by 300 participants drawn from representatives of pastoral communities, concerned local government officials, etc. At the conclusion of the conference a common understanding was reached on policy matters on development and good governance and the basic need for capacity building in pastoral regions.

\section{Activities in Pastoral Woredas}

Nine Pastoral Woredas have been selected from four regions (Somali, Afar, Oromia and SNNP) and various development and capacity building activities were executed in each woreda. A few of these activities in the selected Woredas of Afar and Somali regions are listed below:

\section{Afar Region}

$>2$ types of fodder varieties have been planted and being harvested on 2-fodder seed multiplication centers on 14 hectares. A number of fodder seed stores have also been built.

$>2$ hectares banana trial plantation is underway.

$>1,600$ best variety banana seedlings were distributed to pastoralists.

$>2$ water pumps with a capacity of 200 litters per second were purchased for irrigation and about 400 pastoralist $\mathrm{HHs}$ are benefiting out of it.

$>6$ deep wells that give service for 6,000 people were maintained.

$>2$ water ponds with a capacity of 10,000 cubic meters were constructed.

$>$ 35-km-track road clearance from Elidar-Amino has been accomplished.

$>5$ service cooperatives of 450 members were established and they are now giving service to their members.

$>$ Experience sharing of pastoralists in Oromiya and Tigray regions on water conservation technology has been conducted.

$>$ Training in civil service reform, animal health and agriculture, water technology, mobile health and education system, etc... were conducted for a total of 4,144 persons.

$>$ River diversion in Gewane, Dubti, Afambo and Aysaita areas has been conducted at the cost of Birr 1.7 million,

$>3$ k.m. Main irrigation canal,

$>21 \mathrm{k} . \mathrm{m}$. Area clearing for irrigation,

> 703 hectare weed clearing,

$>$ 40-hectare area clearing for pasture. 


\section{Somalie Region}

$>805$ hectares of land is distributed for 805 persons and is being developed in Gode Woreda.

$>$ Seed distribution in Dolo Odo Woreda,

$>$ Deep well construction in Kebre Beyahe Woreda,

$>18$ k.m RR50 road clearance Gillo-Horkelifo,

$>$ Preparations are well underway for construction of primary schools and health centers in 3 Woredas.

$>3$ sub-surface dams constructed.

$>$ Training in civil service reform, animal health and agriculture, water technology, mobile health and education system, etc were conducted to a total of 5,004 persons.

\section{Pastoral Community Development Project (PCDP)}

This is a program designed to promote an integrated and holistic approach to ensure pastoral area development with 50 million US dollars fund from the World Bank and IFAD. In connection with this project Ministry of Federal Affairs has up to now been conducting the following pre-implementation phase activities:

Regional workshop has been conducted to improve upon the monitoring and evaluation systems of the project,

$>$ Workshop to discuss on the project documents was held in Addis Ababa in the presence of the Bank's representatives and representatives of the four concerned regions,

$>$ The Development Grant Agreement was signed after negotiations with the World Bank,

$>$ Federal and regional pastoral community development project coordination offices have been established,

A workshop to officially launch the project has been conducted on Tikimt 9,1996 E.C. in the presence of donor agencies and representatives of pastoral communities and concerned bureau heads, etc... of the four regions.

\section{Institutional Development: Federal Board for the Four Emerging Regions}

A federal board which coordinates development and capacity building programs designed for the four regions (Somali, Afar, Gambella and Benishangul-Gumuz) by sectoral Ministries has been established. The board conducts its meetings occasionally, gives guidelines to the technical committee on issues related to the development of these areas.

Established under the federal board, the technical committee has as its member's representatives of concerned ministries and other government bodies. Since its establishment the committee has been engaged in coordination activities in designing annual project plans, conducts follow up programs through field visits etc. 


\subsection{Rural Electrification}

As the sub program of its five-year Power Sector Development Program EEPCO is implementing Rural Electrification Project starting from 2001. This subprogram aims at electrifying 164 wereda towns spread all over the country with anticipation of $73 \%$ electrification of wereda towns in all regional states.

The project involves construction of 20 substations of different capacities, construction of about $11.350 \mathrm{kms}$ of distribution lines and construction of 52 diesel stations.

The project cost is estimated to be about 160 MUSD. Funds required for implementation of the project shall be from government of Ethiopia and donor agencies such as World Bank (WB), African Development Bank (ADB) and Arab Ban for economic Development in Africa (BADEA).

Construction activities of the project started in 2001. Up to 7 July 2002, 17 wereda towns and 13 feasible market towns were connected to the system. Additional 30 wereda towns, 32 feasible market towns and 7 on the way rural towns were connected to the system up to July 7, 2003.

In addition to construction activities, three local firms have carried out survey of $5000 \mathrm{kms}$ of distribution lines and topographic survey of 165 weredas and feasible market towns. The survey result shall be an input for design works to be carried out by consultants hired for the project.

\subsection{Rural Telecom Service Expansion}

The nation wide building of telecom infrastructure and realization accessibility has been the prime objective of ETC. This has further been enhanced with the renewed commitment and agriculture led development strategy of the government. Inline with this and in addition to the expansion and replacement of activities performed on exiting facilities 79 new tons have been provide with telecom facilities and their service commissioned in fiscal year 1995. From these 46 were wereda towns, for which access to some form of telecom service has been vital in view of the decentralized government administration.

The remaining 33 tons were non-administrative commercial towns for which the provision of services was made available based on demand and the availability of some form of transmission media.

The transmission media used for the provision of the telecom service were based on a combination of VSAT, UHF, VHF, and Point-to-multi point radio system with the exception of one station, which was provided by microwave link to connect the digital switch at Fincha Sugar Enterprise.

To realize the objective of increasing rural penetration and telecom accessibility, the ETC has planned the extension of telecom services to a further 228 rural towns.

The coverage of the remaining 66-woreda towns is to be served during the 1996 fiscal year expansion activities. 


\subsection{Education}

Education occupies a strategic position in Ethiopia's development priorities. The constitution of the Federal Democratic Republic of Ethiopia (1994) states, "to the extent the country's resources permit policies shall aim to provide access to public health and education". The Education and Training Policy (1994), the Education Sector Development Program (ESDP) and the Five-Year National Development Plans clearly state Ethiopia's commitment to promoting access to quality learning opportunities for all children, which is also consistent with the MDGs.

The multi-year ESDP seeks to address the problems of access, equity, quality, relevance and efficiency in the education sector, with long-term goal of achieving universal primary education by the Year 2015. The ESDP aims to broaden access to education as part of a strategy to accelerate economic growth and the reduction of poverty. Accordingly the first five year's Education Sector Development Program (1997/98-2001/2002) was launched in 1997/98. The second phase of the program, ESDP II (2002/03-2004/05) spans for three years and is currently under implementation. It aims at achieving SDPRP and MDG targets.

\section{Overview of Policy Measures and Actions}

One major policy measure taken in the sector during 2002/03 is preparing and issuing a guideline that creates conducive atmosphere where by the community, particularly parents, are empowered to actively participate in the educational administration, budget allocation and the over-all activities of schools. It is designed to bring decision-making closer to local communities. Therefore, communities shall be involved in managing schools, educational finance, undertaking school-centered studies, maintaining quality of education, including in the revision of primary school curriculum and preparation of textbooks, raising enrolment of female students, reducing dropouts, strengthening the relation between the community and schools, and supporting teachers by addressing their problems. To achieve this, Woreda Education and Training Management Boards, Kebele Education and Training Management Boards as well as Parent-Teacher Associations are established at woreda, kebele and school level respectively. Recurrent budget is given to schools in a form of block grant. In addition an incentive mechanism is set to encourage schools that demonstrate outstanding performance in terms of community participation, reducing dropout students, raising the enrollment of female students, good performance in $8^{\text {th }}$ grade or $10^{\text {th }}$ grade national examinations, and in employing various schemes to generate income.

The Higher Education Act has been proclaimed by Parliament in June 2003. The Proclamation creates appropriate legal framework so that research conducted by higher education shall be problem solving and directed towards the utilization of the potential resources of the country. It also provides for the academic freedom, administrative autonomy and accountability of the higher education institutions, and determines the directions of the private higher education institutions in order to promote their contribution in expanding training and research.

The mechanism of cost sharing via a "graduate tax" has been introduced as one of the financial reforms in the higher education sub-sector. This scheme is believed to make the educational budget more equitable, and more efficient in the allocation of social resources. It shall also have positive spillover effects on the internal managerial efficiency of institutions, which in turn will allow for greater access. 
As a key part of higher education reform, preparation is underway to allocate an annual block grant budget to public institutions based on a funding formula. This new system of budget allocation shall be based on number of students admitted, number of students graduated, the quality of education, research and community services rendered by the institution, the ratio of women and those from the developing regions and nationalities, and the ability of the institution to generate additional income. This system will make the institutions more efficient, competitive, and innovative.

\section{Overview of Implementation of Major Education Programs During 2002/03}

Education is a key element in support of each of the four pillars of the Sustainable Development and Poverty Reduction Program (SDPRP). Through ESDP II the aim is to increase access to education at all levels and to ensure that the quality of education is improved, in a sustainable manner.

Accordingly there has been a significant progress in 2002/03 in increasing access to education at primary, secondary, technical vocational and tertiary levels. The enrolment in grades 1-8 increased from 8.1 million in $201 / 2002$ to 8.7 million in $2002 / 2003$, the enrolment of girls from 3.3 million to 3.6 million, while enrolment of boys increased from 4.8 million to 5.1 million. Accordingly, compared to 2001/2002, the national GER for primary (1-8) has increased by 2.8 percentage points and has become $64.4 \%$ by 2002/2003. GER for girls moved up from $51.2 \%$ to $53.8 \%$, and for boys from $71.7 \%$ to $74.6 \%$. The Net Enrolment Ratio (NER) for regular students increased from $52.2 \%$ in $2001 / 2002$ to $54.0 \%$ in $2002 / 2003$. NER for girls increased from $45.2 \%$ to $47.2 \%$, and for boys from $59.0 \%$ to $60.6 \%$.

The GER for girls and boys in secondary schools has reached to $14.3 \%$ and $24.0 \%$ respectively. As a result the overall Enrollment in secondary schools has become 19.3 percent in $2002 / 03$, which is higher by 2.2 percentage points compared to the previous year. A total of 72,162 students (out of which 54,026 are regular and 18,136 are evening students) were enrolled in 134 government and 19 non-government TVET schools in the 10+1 and 10+2 TVET programs. The share of female enrolment is $48.2 \%$.

Total enrolment in higher education institutions has leaped from 86,145 in 2001/2002 to 147,954 (25.3\% female) in 2002/2003 in all programs for both government and nonGovernment institutions, showing an increase of $45.3 \%$ in access compared to the year $2001 / 2002$. Total number of students in the regular program is 77,946 in $2002 / 2003$, which is higher by 29,803 students than that of in 2001/2002. The share of non-government institutions is $24.0 \%$ of the total; and this share is higher by 5.25 percentage points compared to $2001 / 2002$.

Following are major activities performed and progresses made in the three sub-sectors of education with the aim of providing quality education and training in line with the targets set in the SDPRP.

\section{General Education}

At national level, in 2002/2003, 97.1\% of first cycle primary school (grades 1-4) teachers are certified, while in the second cycle (grades 5-8) $28.7 \%$ are certified to teach at this level. Currently, about 21,400 teachers are enrolled in diploma program through distance education 
to upgrade their level of qualification from certificate to diploma level; and as a result the percentage of certified teachers in the second cycle will increase to over $70 \%$.

About $39 \%$ of secondary school teachers in 2002/03 have first degree and are qualified for the level. This shows an increase of 5.3 percentage points compared to 2001/2002. To improve this situation, currently 5,716 teachers, who have diploma and teach in secondary schools, are enrolled in summer undergraduate degree programs. This will improve the percentage of unqualified teachers. Moreover, the expansion of education faculties in the six universities will expedite the availability of qualified teachers in secondary schools.

The primary Pupil-Teacher Ratio (PTR) in 2002/03 has become 65. This is higher by 2 points compared to the previous year. Although the PTR shows an increasing trend in the past five years in absolute terms, the level of increment is decreasing down from year to year. The PTR for secondary schools has decreased from 49 in 2001/02 to 45 in 2002/03.

The Pupil-Section Ratios (PSR) in 2002/03 were 73 and 77 for primary and secondary schools respectively. The PSR for primary has been showing an increasing trend up to $2001 / 02$. However, although the GER has increased by 2.8 percentage points, it was possible to maintain the PTR level of 2001/02 in 2002/03 due to efforts made to construct additional schools and classrooms by regional governments and communities.

Moreover emphasis was given to the implementation of the following educational programs and activities that are strategically important to bring about fundamental changes in the education system, under general education in 2002/2003.

i) Curriculum revision

Regional Education Bureaus have revised the primary school textbooks based on the findings of the Summative Evaluation and new developments in the country.

ii) Overhauling system of educational leadership and management

a) Increasing awareness among teachers

Conferences were organized through out the country to over 146,000 teachers -primary to tertiary level and for both government and non-government schools and institutions; with the aim of popularising the various national policies, strategies and directives as well as to enable them play their role of producing productive and responsible citizens that the country needs.

b) In-service training to school principals and supervisors

In-service summer training to primary school head teachers is organized in the teacher training institutions. The course for the secondary school principals is given in the six universities focusing on educational leadership, management, support, monitoring and control.

iii) Civics and Ethical Education as a subject

The education system has a societal responsibility to produce good and responsible citizens who understand, respect and defend the constitution, who respect democratic 
values and human rights, develop attitude for research and work and solve problems, develop a sense of citizenship to participate in and contribute to the development of community and the country. To achieve this, a curriculum has been developed, appropriate textbooks prepared for each grade, teachers trained and Civics and Ethical Education introduced as a subject in primary and secondary schools.

iv) Teachers Education System Overhaul /TESO/

Improving the competence of teachers is essential for the improvement of the quality of education offered at all levels. To achieve this new curricula have been developed for teacher training institutes and colleges that train teachers for grades 1-4, 5-8 and 9-12. Institutions are now preparing training modules based on the agreed upon standardized areas of training. A study on how to launch a system of on- the job- training for teachers, that will enable teachers to be perpetual learners or a learning community, has been conducted. Strategies are being developed in order to translate the study into action.

Most of the teacher trainers now working in the various institutes, colleges and universities are not themselves trained as teachers. Therefore, a Higher Diploma Program has been developed for such teacher trainers. The course is on -the-job-training. About 500 teacher trainers shall be enrolled for the Higher Diploma Program in the first round.

v) Improving English Language Teaching

English is taught as a subject starting at grade 1 and is a medium of instruction in the secondary and tertiary levels. English language proficiency of teachers is low. This in turn has affected the quality of education offered at the various levels. An English Language Improvement Programme (ELIP) has been initiated to raise the quality of English Language teaching. Approximately 140,000 teachers will go through a 200 hours of language training in two years time. In 2002/2003, about 900 teacher trainers were trained in the pilot phase, of which 56 have attended a Post Graduate Certificate Course to become core national trainers. As a follow up, over 1500 teachers have been trained for 200 hours. 40,000 teachers have attended face-to-face training in the summer.

vi) Improving access to primary education in pastoral and semi- agriculturalist regions/areas

Regional disparity in access is a concern, with the GER in the two under-served regions (Afar and Somali) well below the national average, both with a GER below 15\%. This is true also in pastoral areas in Oromiya and SNNPR. A Special Task Force has been established in the Ministry of Education to coordinate the Pastoral and SemiAgriculturalist Education Program that is being implemented. Curricula have been developed and training manuals have been prepared to train facilitators and 84 teacher trainers. Training was given to seven textbook writers.

vii) Using Information, Communication and Technology /ICT/ for education and training 
The use of ICT will contribute to the improvement of the quality of education. To improve the educational broadcasts, modern satellite technology is to be installed. Procurement of television set, generators and other equipment are under way. A consulting firm has been selected and is developing programs for six subjects (Biology, chemistry, physics, mathematics, English, and civic and ethical education) that will be broadcasted to secondary schools.

viii) HIV/AIDS Education

A Task Force has been established in the Ministry of Education to coordinate efforts to promote HIV/AIDS Education and to mainstream it in various programmes. A Study on the Impact of HIV/AIDS on Education in Ethiopia has been undertaken and will be used to devise improved strategies .

HIV/AIDS Source Material for Teachers has been prepared and distributed to regions by the Institute for Curriculum Development and Research. The Regional Educational Radio Programs have been broadcasting several radio programs on HIV/AIDS to schools as well as to the public. Anti-HIV/AIDS clubs are established in schools.

\section{Technical Vocational Education and Training}

The TVET program is aimed at increasing enrolment from 25,000 to 130,000 by the end of the plan period, 2004/05. In order to achieve the goals of the skilled manpower requirements of the economy and eventually to meet the national development goals, the following activities have been accomplished in 2002/2003 .

i) The curriculum for first year and second year was revised for 24 and 21 areas of training/vocations respectively. New curriculum was developed to the $10+3$ program for 19 trades.

ii) Skill upgrading training was given to 2551 TVET teachers, principals and administrators.

iii) About 1542 TVET teachers are selected to follow undergraduate in-service degree program in one college and 4 universities.

iv) 52 expatriate teachers were employed in order to alleviate shortage of trained teachers in the TVET schools.

v) A legal framework / proclamation/ for the TVET management and operations has been drafted, submitted to the Council of Ministers. The draft is being revised as per the comments given.

vi) Six directives and guides have been developed on accreditation, apprenticeship, trade testing, certification, financial management, cost sharing scheme.

vii) Occupational training standard has been developed for 28 vocational training areas. 
viii) Construction is under way to upgrade 8 TVET schools to college level, to build 30 libraries, to expand 3 teacher- training institutes.

ix) $\quad 250$ TVET teachers received training on entrepreneurship development.

$\mathrm{x}$ Training was given to 134 vocational counsellors and 27 apprenticeship supervisors.

\section{Higher Education}

i) The new first- year intake in higher education in $2002 / 2003$ was 18,074 , of whom 12,291 joined degree and 5,783 joined diploma programs. Over 1161 entered to the postgraduate program.

ii) Conferences were organized for all tertiary level teachers and personnel for 3 weeks on their role to produce citizens with the required ethical behavior, productivity and initiative to work .

iii) A higher education proclamation has been submitted and endorsed by the Parliament.

iv) About 100 managers of higher education were trained to improve the leadership and management of institutions of higher learning.

v) All preparatory works, including the preparation of directives for implementation, to introduce cost sharing scheme in higher education have been completed.

vi) Two autonomous organs, Higher Education Relevance and Quality Follow-up Agency and the Higher Education Strategy Center are established. The Agency supervises the relevance and quality of higher education offered by any institution including the non-public. The objective of the Center is to formulating vision and strategy in order to make higher education compatible with the country's manpower needs as well as with appropriate policies and with due consideration to global situations, and advise the Government on such matters.

vii) 302 expatriate teachers have been employed to teach in the higher education institutions. 25 international volunteers have come to teach in higher education institutions.

Table 11: Targets and Performances During 2002/03

\begin{tabular}{|l|l|l|l|}
\hline No. & Indicators & $\begin{array}{l}\text { Target for } \\
2002 / 2003\end{array}$ & $\begin{array}{l}\text { Status for } \\
2002 / 2003\end{array}$ \\
\hline 1. & Primary (1-8) Gross Enrolment rates & & \\
& $\quad$ Boys & $73 \%$ & 74.6 \\
& $\quad$ Girls & $53 \%$ & 53.8 \\
& Total & $63 \%$ & 64.4 \\
\hline 2. & Grade 5 Completion Rate & $34 \%$ & $34 \%$ \\
\hline 3. & Gender Parity Index (GPI) for grades 1-8 & 0.72 & 0.7 \\
\hline 4. & Textbook/pupil ratio for core subject for Grades 1-8 & $1: 2$ & $1: 2$ \\
\hline 5. & Girls to boys ratio /primary/ & No target set & $41.2 \%$ \\
\hline 6. & Pupil: Teacher Ratio (1-8) & 64 & 64 \\
\hline 7. & HIPIC Triggers & $50 \%$ & $53.8 \%$ \\
& $\quad$ Female Gross Enrolment & $7 \%$ & $6.7 \%$ \\
\hline
\end{tabular}


The female gross enrolment exceeded the target by 3.8 percentage points. The awareness being created in communities on the importance of female education, the establishment of girls' advisory committees to follow up as well as undertake house-to house visits to advise parents to send their daughters to schools, the establishment of parent-teachers associations, etc has contributed greatly. The Girls Education Initiative Project that is being implemented in regions with relatively high gender gap has a contribution too.

The repetition rate for primary for $2001 / 2002$ was $9.9 \%$., which is less by 0.6 percentage points than the previous year. The repetition rate for $2002 / 2003$ is $6.7 \%$. This dramatic change has been brought because of two major reasons. Firstly, although there has been a policy of automatic promotion through continuous assessment for grades 1-3, this has not been implemented in many regions resulting in high repetition rate at the lower grades. Secondly, teachers were made to discuss and realize the pedagogical benefits of the policy in the teachers' conferences organized throughout the country in 2002. As a result, teachers are applying the continuous assessment approach and providing full academic support to students thus reducing the repetition rate significantly.

\section{Table 12: Trends in Public Spending' on Education \& Training}

Value in Million Birr

\begin{tabular}{|c|c|c|c|c|c|}
\hline Item & $2001 / 02$ & $\begin{array}{c}2002 / 03 \\
\text { Pre. Actual }\end{array}$ & $\begin{array}{l}\text { 2003/04 } \\
\text { Budget }\end{array}$ & $\%$ Change & $\%$ Change \\
\hline 1 & 2 & 3 & 4 & $5=3 / 2$ & $6=4 / 3$ \\
\hline Recurrent & 1777.0 & 2276.0 & 2711.3 & 28.1 & 19.1 \\
\hline Capital & 539.8 & 898.8 & 1308.5 & 46.9 & 65.1 \\
\hline Total & 2316.8 & 3174.8 & 4020.0 & 32.5 & 31.0 \\
\hline Total Public Spending & 17651.5 & 18137.1 & 23448.5 & & \\
\hline Education spending as \% of Total & 13.1 & 17.5 & 17.1 & & \\
\hline \multicolumn{6}{|l|}{ Per Capita Public Spending (Birr) } \\
\hline Recurrent & 26.8 & 33.4 & 38.7 & 24.6 & 15.9 \\
\hline Capital & 8.2 & 13.2 & 18.7 & 41.5 & 61.2 \\
\hline Total & 35.0 & 46.6 & 57.4 & 28.6 & 27.6 \\
\hline Mid Year Population (Million) & 66.2 & 68.2 & 70.1 & 3.0 & 2.8 \\
\hline
\end{tabular}

Out of the total budget allocated for education, a total amount of Birr 3174.8 million was utilized during 2002/2003. This represents a 32.5 per cent increase over the previous fiscal year. Both capital and recurrent expenditure have also increased by 46.9 per cent and 28.1 per cent, respectively over 2001/02. The total budget allocated for education increased by 31.0 per cent over the 2002/03 actual expenditure and reached Birr 2020.0 million in 2003/04. The increment in the capital budget $(65 \%)$ is much higher than the recurrent budget $(19.1 \%)$.

\section{Constraints and Possible Remedies}

\footnotetext{
${ }^{9}$ Public spending for all years and all sectors covers all sources: treasury, external loan, and external assistance
} 
The major constraint in the implementation of the sector program is the low implementation capacity, at the various level and especially at woreda level. This is manifested in the low utilization of allocated capital budgets, as well as weak monitoring and reporting. To address this constraint a rigorous capacity building program is needed. A task force composed of the Ministry of Education and donors has been set up to identify areas of capacity building at all levels, device strategies to coordinate capacity building support and funding and to draft implementation schedules. Moreover, the low construction capacity of contractors has contributed to delays in the construction of schools and higher education institutions. In this regard, it is believed that the Government's current undertakings to build the capacity of the construction sector in the country will improve the situation.

\subsection{Health}

\section{General Background}

The Health Sector Development Program (HSDP) currently under implementation in Ethiopia is a comprehensive Health Sector Development Planning based on the principles of SWAPs. HSDP is part of the Government's 20-year Health Sector Investment Program designed to be implemented in four phases of five-year rolling plans. The first phase (HSDP I) was launched in EFY 1990 (1997-98) to cover five years up to EFY 1994 (2001/2002).

The second phase of the Health Sector Development Program (HSDP II) which coincided with the three-year SDPRP period (2002/03-2004/05), is currently under implementation. HSDPII, which is aligned with the second Five-Year National Development Plan of the country, has been designed to ensure linkages with the wider policy frameworks such as SDPRP, ADLI and MDGs. For budgeting and planning purposes, the program activities of HSDPI and HSDPII have been organized around eight separate but interrelated components.

Financial allocation by these components was intended to reflect relative priorities for investment within the sector, and also to ensure intimate linkages between the components. Both phases have clear strategies for making targeted interventions against poverty related diseases, which are in the main HIV/AIDS, Malaria and Tuberculosis. Other focus areas of interventions are Child Survival, Reproductive Health and Maternal Health Care.

Overall, the linkage between HSDP, SDPRP, Macro-economic framework of the country and the MDGs are clearly articulated in both phases of HSDP. The design of HSDP and henceforth its implementation focuses on the prevention and control of poverty related diseases with increased intensity aimed at achieving SDPRP and MDG targets.

\section{Overview of Policy Measures and Actions}

One of the most important policy measures taken during 2002/03 was the Health Sector's engagement in the development of the "Health Extension Package" initiative. The policy measure for this important initiative emerged from the serious consideration of the past gains and challenges in the process of the HSDPI implementation. The health sector has realized that essential health services have not reached the people at the grass-root levels as was expected.

The government of Ethiopia has therefore decided to make a policy decision that paved the way for the introduction of an innovative community-based approach aimed at creating healthy environment through the implementation of Health Extension Package Program 
throughout the country. The program is progressing at piloting stage in five regions, and the lessons learned from this will be used to enriching further refinement of the initiative. As part of preparation for launching the program, 16 training and field implementation health extension packages have been developed, commented upon by wider stakeholders including academic institutions and received acclaimed endorsement by development partners and donor groups. The packages are now fully translated from Amharic version into English and are awaiting final printing and distribution so that the texts will be ready for the first batch of trainees of around 3,000 due to start next year.

The other important measure introduced by the health sector has been the development and execution of a policy on the supply and use of Anti-retroviral Therapy/Drugs (ART). The policy has been fully introduced with the necessary preparations including the training and policy introduction to 340 health professionals and selected public and NGO based drug outlet institutions.

The refinement in the Health Care Financing reform has shown significant progress and has reached its final stage for legal backing and legislation. The HCF reform initiative has clearly embraced the development of an inclusive health care financing reform for the Hospital Sector with the aim of introducing private inpatient wings and services in the public health facilities including outsourcing or contracting out non-medical services to the private sector to improve the cost-effectiveness of public-based health care financing. This progressive $\mathrm{HCF}$ reform also enabled the health sector to engage in the implementation of "Revolving Drug Fund" (RDF) initiative through the establishment of special pharmacies in the first phase of 150 public health facilities throughout the country with the aim of covering all hospitals and 50\% Health Centers by the end of FY 2004/05.

\section{Overview of implementation of major health programs during 2002/03}

Expansion of the health care delivery system has shown significant progress and the data for the reporting year indicate achievement well over the target in all categories of health expansion plans. This has allowed the potential health coverage to increase from $58 \%$ to $60 \%$, surpassing the SDPRP target by $4 \%$ for the reporting year.

The preliminary report for other major indicators also show that the malaria prevalence rate is 8.7\%, DPT3 50.4\%, Contraceptive Prevalence Rate 18.7\% and health facility based DOTS service coverage $51.1 \%$. In terms of Human Resource availability, the preliminary report also indicates that the targets for 2003 have been achieved for all professional categories but the pharmacists. The ratios for selected health professional to population for SDPRP monitoring milestones were as follows: Doctors/ Health officers 1: 28,339; Nurses 1: 5,236; Technicians 1: 34,614; Sanitarians 1: 69,228; Frontline Health Worker 1: 6,689 and Pharmacists 1: 569,661 .

Other important program activities worth mentioning for this progress report are the finalization of "Minimum Health Service Package" and the development and finalization of a "Health Extension Package" with clear definition on the scope of its field level implementation. In this regard, the development of a Minimum Health Service Package is now $85 \%$ completed and is expected to be ready in few months for wider consultation and finalization. The development of a Health Extension Package has progressed very well that not only it defined the scope of implementation but it has been put on pilot in five regions. As part of the necessary preparation, curriculum development and finalization of 16 packages for 
training and implementation are in their final stage for publication and distribution. Preparation is also underway to start enrollment of the first batch of health Extension worker trainees by the start of next year.

For the reporting year of 2003, the health sector also saw its outstanding success in securing additional funds from international and bilateral donors. The signing of agreement with the Global Fund has brought forward the much-needed additional health sources in the order of USD 6.5 million for Tuberculosis control and USD 17.8 million for malaria control program. These amounts are the first disbursements from a two-year total grant of USD10.9 million and USD27.0 million, respectively. In addition, the health sector has also signed an USD55.0 million grant with the Global Fund for two years for the nation-wide implementation of HIV/AIDS program and the first disbursement amounting roughly USD21.0 million is expected to be released soon. Other successful bilateral agreements for 2003 were from the Italian Cooperation amounting USD2.9 million and from Irish Aid amounting USD5.5 million. The securing of these additional funds will make significant contribution in the implementation of major health programs and an improvement in the sensitive SDPRP indicators for the following reporting year.

\section{Overview of constraints that hampered the performance of the health sector and suggested remedies}

Major constraints that hampered the performance of the health sector includes in the main shortage of resources to match with the planned activities of the HSDP, inadequate Health Service Management that would require increased need for capacity building, particularly managerial at district and operational level. Other important constraints are the continued chronic shortage of health professionals coupled with a high rate of staff turnover. The health sector also continued to suffer from mismatch of Human Resource training \& deployment. It is also worth mentioning that the health sector has not made significant progress in optimizing the NGO and the private sector's engagement in the implementation of HSDP.

Out of the total budget allocated for health, a total amount of Birr 923.9 million was utilised during 2002/03. This represent a 3.5 per cent increased over the actual expenditure of fiscal year 2001/02. The total budget allocated for the health sector in 2003/04 increased by 69.3 percent compared to 2002/03 actual expenditure and reached Birr 1695.3 million. As indicated under Table 13 above, the increment in the capital budget (98.7\%) is much higher than the recurrent budget $(53 \%)$ 
Table 13: Trends in Public Spending ${ }^{10}$ on Health, Value in Million Birr

\begin{tabular}{|l|l|l|l|l|l|}
\hline Item & $2001 / 02$ & $\begin{array}{l}2002 / 03 \\
\text { Pre. } \\
\text { Actual }\end{array}$ & $\begin{array}{l}2003 / 04 \\
\text { Budget }\end{array}$ & \% Change & Change \\
\hline 1 & 2 & 3 & 4 & $5=3 / 2$ & $6=4 / 3$ \\
\hline Recurrent & 521.6 & 526.0 & 1103.2 & 0.7 & 53.0 \\
\hline Capital & 273.2 & 387.9 & 592.1 & 9.2 & 98.7 \\
\hline Total & 794.8 & 913.9 & 1695.3 & 3.5 & 69.3 \\
\hline Total Public Spending & $\mathbf{1 7 6 5 1 . 5}$ & $\mathbf{1 8 1 3 7 . 1}$ & $\mathbf{2 3 4 4 8 . 5}$ & & \\
\hline Health spending as \% of Total & $\mathbf{4 . 5}$ & $\mathbf{5 . 0}$ & $\mathbf{7 . 2}$ & & \\
\hline Per Capita Public Spending (Birr) & & & & & \\
\hline Recurrent & 7.9 & 7.7 & 15.7 & -1.3 & 49.4 \\
\hline Capital & 4.1 & 5.7 & 8.5 & 7.3 & 93.1 \\
\hline Total & 12.0 & 13.4 & 24.2 & 1.7 & 64.4 \\
\hline Mid Year Population (Million) & 66.2 & 68.2 & 70.1 & 3.0 & 2.8 \\
\hline
\end{tabular}

Source: MoFED

\subsection{Roads}

A strategic component of the SDPRP investment program is the RSDP II, which aims to maintain and expand the existing road network, increase access to markets, aid the integration of the national economy and stimulate food security and rural development and thus reaching the MDGs by 2015.

An innovative aspect of RSDP II is that it addresses the requirements of travel and transport at village level through the Ethiopian Rural Travel and Transport Sub-Program (ERTTP). Many villages are cut off from useable road connection during the rainy seasons. Access to all-weather roads is a crucial requirement for the development of small-scale farming. The ERTTP seeks to facilitate agricultural and other commercial activities in the regions, and make a critical contribution to the growth in rural output and is a crucial component of the rural development initiative. These investments will have a direct impact on rural household incomes and thus food security.

The Ethiopian Roads Authority is the responsible body for implementing the road program. Increases in heavy vehicles and axle loading have severely damaged existing roads. Therefore during FY 2002/03, road rehabilitation and maintenance works were given top priority. New road construction in the areas of major economic and population centres and upgrading of gravel roads to asphalt are also underway.

During fiscal year $2002 / 03$, a total of $1005 \mathrm{~km}$ of roads were upgraded rehabilitated, constructed or maintained. The accomplishment was about $248 \mathrm{~km}$ rehabilitation of asphalt

\footnotetext{
${ }^{10}$ Public spending for all years and all sectors covers all sources: treasury, external loan, and external assistance
} 
roads, $25 \mathrm{~km}$ of gravel roads, upgrading of $284 \mathrm{~km}$ from gravel to asphalt road surface and $103 \mathrm{~km}$ of newly constructed primary roads. In addition to routine maintenance, heavy maintenance was applied to $15 \mathrm{~km}$ pf asphalt and $45 \mathrm{~km}$ of gravel roads. The overall physical accomplishment of the Authority was $72 \%$ of the planned target. Road density increased from $29 \mathrm{~km}$ per 1000 square kilometer in 2001/02 and reached $31 \mathrm{~km}$ per square kilometer by the end of the year under review (2002/03). The reasons for falling short of the target included shortage of equipment, slow mobilization, shortage of skilled manpower and poor management of the projects.

Routine maintenance activities included $16,183 \mathrm{~km}$ of main roads under maintenance of which $3,915 \mathrm{~km}$ were asphalt and $12,268 \mathrm{~km}$ were gravel roads. The overall physical performance of road maintenance was above the average production target of the reporting period

Table 14: Trends in Public Spending ${ }^{11}$ on Roads, Value in Million Birr

\begin{tabular}{|l|c|c|c|c|c|}
\hline Item & $\begin{array}{c}2001 / 02 \\
\text { Actual }\end{array}$ & $\begin{array}{c}2002 / 03 \\
\text { Pre. Actual }\end{array}$ & $\begin{array}{c}2003 / 04 \\
\text { Budget }\end{array}$ & $\begin{array}{c}\% \\
\text { Change }\end{array}$ & \% Change \\
\hline 1 & 2 & 3 & 4 & $5=3 / 2$ & $6=4 / 3$ \\
\hline Recurrent & 119.0 & 139.0 & 129.8 & 16.8 & -6.6 \\
\hline Capital & 1526.7 & 1760.7 & 3286.6 & 2.9 & 109.2 \\
\hline Total & 1645.7 & 1899.7 & 3416.4 & 3.9 & 99.8 \\
\hline Total Public Spending & $\mathbf{1 7 6 5 1 . 5}$ & $\mathbf{1 8 1 3 7 . 1}$ & $\mathbf{2 3 4 4 8 . 5}$ & & \\
\hline Roads spending as \% of Total & $\mathbf{9 . 3}$ & $\mathbf{1 0 . 5}$ & $\mathbf{1 4 . 6}$ & & \\
\hline Per Capita Public Spending & & & & & \\
(Birr) & & & & & \\
\hline Recurrent & 1.8 & 2.0 & 1.9 & 1.1 & 0.0 \\
\hline Capital & 23.1 & 25.8 & 46.9 & 0.0 & 103.9 \\
\hline Total & 24.9 & 28.0 & 48.8 & & \\
\hline Mid Year Population (Million) & 66.2 & 68.2 & 70.1 & 3.0 & 2.8 \\
\hline
\end{tabular}

Source: MoFED

Out of the total Budget allocated for roads, a total amount of Birr 1899.7 million was utilized during 2002/03. This amounts to an 8.1 per cent increase over the 2001/02 FY. The total budget allocated for roads increased by 53.1 per cent compared to the 2002/03 actual expenditure and reached Birr 2723.7 million in 2003/04. This mainly comes from an increment of 50 per cent in the capital budget and 85.5 percent in the recurrent budget (Table 14).

\section{Overview of Policy}

The success of the road sector program does not only depend on physical construction. The efficiency and sustainability of transport services and the enhanced road network also need to be supported by appropriate policies. Key policy and institutional actions included:

\footnotetext{
${ }^{11}$ Public spending for all years and all sectors covers all sources: treasury, external loan, and external assistance
} 
Reorientation of investment priorities towards rehabilitation and maintenance;

$>$ Collection of revenues for road maintenance from road users;

$>$ Implementation of a program of background studies.

$>$ The ERA and RRAs have been restructured and given full autonomy, with clearly defined powers and tasks, to enable the further decentralization of decision-making. ERA is currently decentralizing maintenance districts, to the level of cost and profit center, to effectively maintain and administer the road network. The arrangements would also lead to increased efficiency through increased competition with the private sector whose participation in maintenance is also expected to increase.

> Improved management techniques are being introduced, more skilled manpower recruited, and an improved payment scale introduced.

$>$ Commercialization is being introduced in appropriate areas of ERA's operations:

$>$ ERA is contracting out construction and maintenance of roads, increasingly limiting its role to planning and contract administration,

$>$ The planning of projects has improved. No project is implemented without being appraised as economically viable and of proper design,

$>$ ERA's own account projects are operated on a similar basis as those implemented by contractors (e.g., contracts through Letters of Understanding (LOUs), and payment to projects are effected on the basis of payment certificates), and

$>$ Supervision engineers who verify both the quality of work and payment are engaged in all ERA own account works including the maintenance works.

\section{Enhancing capacity of local private contractors}

Enhancing domestic road construction and maintenance capacity has been identified as an important aspect of ensuring the sustainability of the road network. Some measures to facilitate local contractor participation have been introduced including contracting out works, a study to identify the problems of the industry, reforming the contract documents required for Government projects, etc.

The Government is seeking a new partnership with the private sector through facilitating capital/credit access, relaxing some of the contract conditions, etc. The private sector is now expected to play an active role in periodic maintenance and construction of roads and in the near future in routine maintenance, although length men are being engaged on individual contracts for road section maintenance.

\section{RSDP Monitoring Indicators (and Poverty Impact Measurements)}

A Monitoring system for the RSDP has been introduced with the assistance of EU. Four Monitoring Reports have so far been prepared and indicators updated. The data generated has been useful to the ERA management and the Donor Community in drawing lessons improving effectiveness of implementation, minimizing costs and increasing benefits and sustainability. ERA is also carrying out studies to measure the impact of roads on poverty reduction, which would include the establishment of transport-poverty observatories with financial support from Japanese PHRD and IDA funding.

\section{Labor Based Activity}

Since 1998/99 ERA, has been increasing labour intensive road maintenance activity, particularly through the recruitment of contract labour from communities living adjacent to 
the road- referred to as "length persons". Various studies have found that properly trained and rewarded labour is generally more reliable than using complex equipment for selected routine maintenance activities including limited spot regravelling, pothole patching, etc. Recruitment close to place of work reduces costs and logistical problems. The approach adopted in the "length person" system is that two km segments are allocated to each "length person". It is planned to implement at least six per cent of districts works program in undertaking brush clearing, culvert cleaning and ditch clearing by labour. Most Districts have achieved their targets

A program is being launched to cover $5000 \mathrm{~km}$ of regional and federal roads through a "length person" maintenance system over the coming five years.

\section{Resource Mobilization and Road Financing}

Roads have been accorded high priority, as poor roads have impeded the evacuation of crops and the delivery of agricultural inputs, and held back improvement of agricultural productivity and food security. To ensure availability of finance for maintenance, the Road Fund Administration Office established in 1997 finances routine maintenance expenditures of ERA, RROs and municipalities. For 2002/03 the road fund allocated Birr 178.0 million for routine maintenance. ERA's routine maintenance is now fully covered by the Road Fund and the Fund has started financing periodic maintenance.

Improving Network Planning: Road priorities should be based on economic benefits, enhancing strategic links in the network, and contributions to regional integration, among other development objectives. The existing layout is a skeletal network radiating from Addis Ababa, but failing to reach the farthest extremes of the country. The radial orientation results in a poor degree of interconnection between different parts of the country.

Efforts are being made to develop a more coherent, network-based approach to road planning and management in contrast to the piece-meal approach that project-based investment appraisal produced. This will include the design of a 'federal network' that could be affordable within realistic resource availability and priority functions. The planned network should be:

$>$ Responsive to the country's food security and poverty alleviation objectives

$>$ Improve the internal connectivity and opening up of potential areas for development; and

$>$ Strengthen the key export-import corridors to reduce transportation costs.

Road Safety and Axle Load Control: Road contracts under RSDP include a safety component of better pavement markings and delineation, improved guard and bridges rail systems, safety lighting, as well as elimination of high hazard locations. In addition, more effective enforcement of traffic laws and regulations, and education and publicity campaigns are needed to modify driver behaviour. Through the technical assistance provided by EU, the sectoral road safety study has been completed, leading to the establishment of an Interim Working Group to implement a two-year action plan.

Transport Regulations: A study, which reviewed the road transport regulations and offered recommendation of further actions to facilitate road transport services and competitiveness, 
was completed in August 2002. Based on this study RTA is drafting various proclamations and regulations.

Mitigation of Environmental Impact during Road Construction: The Environmental Management Branch has been established under the ERA's Planning and Programming Division, staffed by professional environmentalists. ERA management has changed the name of the Environmental Monitoring Branch to Environmental Monitoring and Safety Branch (EMSB). The Branch is processing the recruitment of a geologist and the transfer of a second sociologist from the personnel branch to the EMSB strengthens its work on social aspects. The head of the unit who is on study leave will rejoin the unit in March 2004. The unit will then comprise an environmentalist, an ecologist, two sociologists and a geologist. In addition, the unit has two consultants, a sociologist and a nurse (on two-year contracts) working full time on HIV/AIDS. The Branch reviews EIA reports prepared by Design and EIA Consultants, monitors environmental and social impact mitigation measures on road projects. In addition, a standard Environmental Methodologies and Procedures Manual and Resettlement/Rehabilitation Policy Framework have been completed with World Bank support. The Branch has also a plan to undertake EIA studies for ERA own force projects in future and incorporate social dimensions into road network planning.

Constraints on performance: There is a lack of relevant experience of road construction by domestic contractors through lack of opportunities, and generally weak site management and staff. In addition to a shortage of skilled manpower, there are also shortages of key equipment in some contract projects. Contractors (including international ones, are slow in mobilizing to implement projects, in light of which contractors are often unrealistic in their projections and resort to claims. Some of the international contractors (Chinese especially) also perform poorly than what the pre-qualification submissions indicate). The domestic contractors are also characterized by lack of capital and equipment, needed for road construction and have difficulties in obtaining access to credit and bank and local financial institution support in obtaining performance and bid bonds, etc. In response to these difficulties, new management teams have been assigned to problem projects. To solve the problem of shortage of equipment some contractors are currently leasing equipment. To deal with slow contractor mobilization, ERA and their consultants request contractors to submit revised practical mobilization schedules and work closely with contractor to achieve timely fulfilment of contracts. ERA has been conducting site meetings every month to discuss any issues raised related to the progress of work at sites, and it is being strengthened under RSDP - IDA APL1 to address recurring issues.

Lengthy procurement processes required by some funding agencies, and other bureaucratic delays in formulation, analysis of bids, review and approval of evaluations on the ERA side delay implementation. There are shortages of equipment and spare parts for own force account projects resulting in projects falling behind schedule. When the problems of equipment and spares are solved the performance of the own force account projects is expected to improve. To expand contract management capacity, currently more than 50 engineers are being recruited, and will be accorded the relevant training for working in the contract administration division.

\subsection{Water Resource Development}

Given the vulnerability to drought and the constraints on food security and overall rural development resulting from limited water availability, water development is a central element 
in the SDPRP and MDGs. The Government has set the following sector management policy objectives.

a) Develop, on an equitable and sustainable basis, the country's water resources for economic and social benefits of its peoples

b) Allocate and apportion water resources based adhering to optimum allocation principles that incorporate efficiency of use, equity of access and sustainability of the resource

c) Manage and tackle drought as well as the associated slow on-set disaster through efficient allocation, redistribution, transfer, storage and use of water resources

d) Tackle and regulate floods, and

e) Conserve and enhance water resources and aquatic environment on sustainable basis.

\section{Implementation of Major Programs during 2002/2003}

Sector development activities carried out in 2002/3 at federal and regional levels included:

a) Irrigation development

b) Urban water supply construction

c) Rural water supply construction

d) Rural and urban water supply rehabilitation

e) Integrated water resources master planning

f) Medium hydropower projects studies and design

g) Lakes water level control

h) Flood control

i) Surface water and sedimentation monitoring

j) Construction of meteorology stations

k) Training and capacity building activities

During the year, a remarkable number of irrigation works were put into operation and were under construction. Water supply construction and rehabilitation in urban and rural areas improved livelihood and reduced risks of contaminated water. To achieve equitable and sustainable development of the country's water resources, integrated water resources master plan studies were implemented and several hydropower projects are under studies.

The construction and rehabilitation of meteorological and aeronautical stations are needed to strengthen the early warning system, accuracy of forecasting and expand regional capacities in meteorological management. During 2002/3 work has continued at regional meteorological offices and rehabilitation of aeronautical stations. Continuing long term tasks relating to control and monitoring of floods, lake water rise and sedimentation were tackled through selected priority intervention areas. Training and capacity building for user communities and implementing institutions are vital and have been carried at different levels and several training fields.

\section{Highlights of program implementation in 2002/3}

\section{i) Irrigation Development}

\section{a) Small and Medium Scale Irrigation Development}

Irrigation development activity ranges from pond construction at household level to river diversion for communal or commercial users. During 2002/3 a total of 45841 Water harvesting ponds river diversion and dam construction for individual and communal irrigation schemes put into operation. 20,730 households have benefited from completed 
irrigation schemes, meeting the target set for the year. About two thirds of the targeted 5,353 hectares of irrigated land development were completed during the fiscal year. In addition, 21 other communal irrigation schemes are under construction and nearing completion, designed to irrigate a total of 2,360 hectares of irrigable land, with 7,565 beneficiary households.

\section{b) Large Scale Irrigation Development}

The Koga Irrigation and Watershed Management Project is a model large-scale irrigation development financed by FDRE and ADB, designed to irrigate 6,000 hectares of farmer's holdings. It is located in a densely populated area characterized by high pressure on natural resources and fragmented farming land holdings in Mecha Wereda, in Amhara Regional State. It combines irrigation development with multiple social development programs aimed at poverty alleviation. During 2002/3 the project entered design stage. Similarly the watershed management and the social development programs are in progress.

\section{ii) Water Supply Activities}

\section{a) Rural Water Supply}

Rural people especially women and children spend considerable time each day in fetching water. Families are exposed to water borne and water related diseases, and during periods of drought when communities are forced to cover long distances to get water for household and livestock use. Improvements in water supply are therefore a crucial input into the SDPRP and to achieve the MDG target on clean drinking water.

During 2002/3, 2,230 hand dug wells (146.5\% of the target), 224 shallow wells (43\%), 65 deep wells (34\%), 446 spring developments (49\%) and a further 852 schemes and rehabilitation works were completed. Rural populations benefiting from the schemes are estimated to be more than 2 Million.

\section{b) Urban Water Supply}

Urban water supply access is by far better than rural areas. Urban water supplies are normally designed to operate for 20 years, with further investment after 10 years operation. The Ethiopian Water Resources Management Policy favors full cost recovery for urban water supply; accordingly financial feasibility and tariff level acceptability are thoroughly examined during studies.

During 2002/3 Regional and Federal bodies conducted studies and design work parallel with the rehabilitation and construction of urban water supply projects. Studies and design works are being conducted in 17 towns by Regional Bureaus. Studies on 10 towns have been conducted through the Ministry of Water Resources with an overall implementation rate of $79 \%$. Besides, 15 other towns benefited from rehabilitation works. The numbers of towns that have benefited from new construction works stood at 21 . The overall urban population benefiting from rehabilitation and new construction works is in the order of 1.2 million. By the end of $2002 / 03$ (June $30^{\text {th }} 2003$ ), $34 \%$ of the population had access to improved water supply of which $25 \%$ are in rural areas and $85 \%$ in urban areas. 
Parallel with the development of water supply schemes (particularly for rural areas), efforts are also currently under way (through regional governments) to rehabilitate non-functioning and/or mal-functioning water supply schemes. Available information from the Ministry of Water Resources indicate that the rate of non-functioning schemes have been reduced from 30 percent to about 23 percent during the fiscal year under review.

Table 15: Access to Water Supply Rural and Urban Areas (\%)

\begin{tabular}{|l|c|}
\hline Areas & $2002 / 03$ \\
\hline Rural & 25.0 \\
\hline Urban & 85.0 \\
\hline National & 34.0 \\
\hline
\end{tabular}

\section{iii) Training and Capacity Building}

Training and capacity building activities is key to sustaining constructed schemes. Training and capacity building activities in 2002/3 have included farmers training on irrigation water management, training of professionals and sub professionals from implementing agencies on irrigation, community level training on rural water supply operation and maintenance. Establishing and strengthening water committees have strengthened management and administration of rural water supply schemes. Training and capacity building included:

To strengthen the regional Bureaus in the area of Ground Water Development and Water Supply Management, professionals and mid level staff was recruited from regions for courses at the training center at Kality in Addis Ababa, established with the support of JICA. The center provided on the job training for 80 professionals and sub professionals during 2002/03. In addition four training centers were established at Maichew, Bahir Dar, Ambo and Awassa. The centers have started admitting 400 trainees from all the regions. Training will take about three years, and is targeted to build the capacity of Woreda water desks by training in water supply \& sanitation, and irrigation. Trainees include electricians, mechanics \& community participation promoters.

\section{iv) Basin Development}

The integrated basin development master plan studies are aimed at the preparation of feasible development interventions over the long-term of 30- 50 years. The master plans seek to identify the best development scenario for specific water basins in the medium \& long term.

In 2002/3 the Wabe Shebelle and Genele - Dawa Basins Development Master Plan studies are in progress. The Wabe Shebelle Master plan studies successfully completed the second phase and the final third phase studies have started. The Genale -Dawa Basin Development Master plan studies have commenced.

\section{iii) Hydropower Projects}

The efficient exploitation of hydropower potential involves a long process, from, identification of potential sites, to construction of dams, powerhouses, substations, transmission and connection to the ICS. Reconnaissance, pre-feasibility and feasibility studies and tender document preparation take not less than five years even if funds are available. 
During the fiscal year Baro, Geba and Berbir Medium-scale hydropower projects were proposed for studies with grant support from Norway and ADB. However, with delayed grants, studies commenced only for Geba, using government budget allocations.

\section{iv) Flood Mitigation and Environmental Study}

Floods from Awash River have caused repeated inundation of pastoral lands and commercial farming areas. Addressing this problem has been the priority task for 2002/3, through a project that aims to decrease flood intensity and frequency through canalization measures and enhancing the capacity to store floodwater for rangeland development and arid areas agriculture uses. During 2002/3 the project study was expected to start, however due to delays in finance, the study has been postponed until next year.

\section{v) Hydrological Stations}

The establishment of 10 new hydrological stations, 10 banks operated cableways and 10 automatic gauging stations were planned for 2002/3. During the year, a total of 12 hydrological stations have been established, and 9 bank operated cableways and 7 automatic gauging stations successfully completed. In 16 selected sample sedimentation areas data collection, analysis and storing to database have been performed.

\section{vi) Meteorological Services}

Under the National Meteorological Services Agency, the establishment of forecasting stations, the construction and rehabilitation of Regional Meteorological Offices, and the development of Aeronautical Meteorological services in four Airports were planned for $2002 / 3$. The establishment of forecasting stations and installation of equipment has been planned at 40 sites and these have been fully achieved. Regional offices in eight regions are being established. The 2002/03 FY also witnessed the development of Aeronautical Meteorological services in four airports. However, only $44 \%$ of the annual plan has been completed.

Out of the budget allocated for water sector, a total amount of Birr 430.0 million was utilized during 2002/03 and this represents an about 45 per cent increase over the previous year. The total budget allocated for the water sector increased by about 73 per cent compared to the 2002/03 actual expenditure and reached Birr 1015.6 million in 2003/04. Total recurrent budget on the sector has increased by about 120 percent during while the capital component showed a 60 percent increase during 2003/04(Table 16 below). 
Table 16: Trends in Public Spending ${ }^{12}$ on Water, Value in Million Birr

\begin{tabular}{|l|l|l|l|l|l|}
\hline Item & $2001 / 02$ & $\begin{array}{l}2002 / 03 \\
\text { Pre. Actual }\end{array}$ & $\begin{array}{l}2003 / 04 \\
\text { Budget }\end{array}$ & $\begin{array}{l}\% \\
\text { Change }\end{array}$ & \begin{tabular}{l} 
Change \\
\hline 1
\end{tabular} \\
\hline Recurrent & 105.6 & 130.0 & 4 & $5=3 / 2$ & $6=4 / 3$ \\
\hline Capital & 299.8 & 455.9 & 730.0 & 52.1 & 60.1 \\
\hline Total & 405.4 & 585.9 & 1015.6 & 44.5 & 73.3 \\
\hline Total Public Spending & $\mathbf{1 7 6 5 1 . 5}$ & $\mathbf{1 8 1 3 7 . 1}$ & $\mathbf{2 3 4 4 8 . 5}$ & & \\
\hline $\begin{array}{l}\text { Agriculture spending as \% } \\
\text { of Total }\end{array}$ & $\mathbf{2 . 3}$ & $\mathbf{3 . 2}$ & $\mathbf{4 . 3}$ & & \\
\hline Per Capita (Birr) & & & & & \\
\hline Recurrent & 1.6 & 1.9 & 4.1 & 18.8 & 115.8 \\
\hline Capital & 4.5 & 6.7 & 10.4 & 0.0 & 136.4 \\
\hline Total & 6.1 & 8.6 & 14.5 & 3.3 & 130.2 \\
\hline $\begin{array}{l}\text { Mid Year Population } \\
\text { (Million) }\end{array}$ & 66.2 & 68.2 & 70.1 & 3.0 & 2.8 \\
\hline
\end{tabular}

Source: $M O F E D$

\footnotetext{
${ }^{12}$ Public spending for all years and all sectors covers all sources: treasury, external loan, and external assistance
} 


\section{Private Sector \& Export Development}

The private sector is increasingly becoming a major actor in industry and services. The growth rate for 2002/03 for non-agricultural sectors and services sectors were $2.6 \%$ and $2 \%$, respectively. However, the following factors have impact on private sector growth: (a) the spill over of dampened demand from the drought-affected economy to the private sector; and (b) the impact of the continuing slowdown of financial sector lending on the private sector (c) power disruption owing to water shortages aggravated by the drought.

Given the dependence on hydro power, it would be appropriate to note the resulting power cuts as being not within the short term control of the government and having a substantial impact on productivity (e.g. at its peak, the power cuts were for 2 out of 5 working days). To address this problem the government introduces private participation and now 5 Memoranda of Understandings are under discussion. In addition, the government has made efforts to fix distribution by improving capacity of the existing distribution company.

With regard to telecommunication, the government remains committed to the process of finding the strategic equity partner for ETC despite an unsuccessful attempt in this regard in late 2002 due to not finding suitably qualified partner. To strengthen the ETA (the regulatory) the capacity building program has been prepared.

The government through its tax reform not only has aimed at broadening the tax base but also to simplify the tax laws as well as to improve tax administration (example large tax payer department) to facilitate private sector participation. In addition, the government has launched private sector capacity building program for MSEs which is funded by EU.

The Government's reform policies and programs are aimed at transforming Ethiopia's weak and fragmented private sector into an engine of growth and development, so that it can realize its potential to create non-farm employment and tax revenue growth. High on the reform agenda are initiatives to facilitate and expand private sector activity. This includes engaging foreign and domestic investors and members of the Ethiopian Diaspora, in export trade and other high value-added economic activities. The government will also partner with the private sector to ensure the efficient delivery of social services such as education, health, water and energy. The technical and vocational education and training program (TVET) aims to deliver an adequate supply of skilled labor to support private sector growth.

As part of ministries selected for fast track implementation of CSRP, MOTI has taken process re-engineering steps to overhaul business registration processes within MOTI and EIA. As a result, the cost of registration has reduced from $\$ 425$ to $\$ 65$ and the time of registration from 44 days to 8 days. Likewise Ministry of Revenue has also conducted process re-engineering for customs clearance and is reducing the processing steps from 72 to 8. This is expected to have major impact in the number of days for customs clearance.

In infrastructure provision, ETC continued its expansion of telecommunication infrastructure and services and a major expansion of the fixed, mobile and internet services is expected to occur in the coming several months - this improving access. Furthermore, ETC has reduced its fee for international call from Birr 17.5/ minute to Birr 11/ minute. Internet cost is also reduced from 56 cents per minute to 15 cents per minute. 
Expanding the supply of affordable land for business development is also high on the Government agenda. The Ethiopian Investment Authority (EIA) is in the process of expanding the supply of available land by assembling an inventory of low cost land equipped with necessary infrastructure. The EIA was set up to be a one-stop service for issuing investment licenses and work permits for expatriates, registering foreign investment, and providing information. Through a related project, the Ministry of Trade \& Industry has initiated a study to formulate a plan to establish industrial zones in 15 regional cities/towns.

In 2002 the Public-Private Consultative Forum was established, co-chaired by the Minister of Trade and Industry and the President of the Ethiopian Chamber of Commerce. This forum has been holding quarterly meetings to identify sectoral policies and strategies that warrant further scrutiny, identify and address implementation bottlenecks related to newly issued proclamations, regulations, and directives, discuss emerging PSD issues, and review directives of federal line ministries that are thought to impede private sector development. To date three quarterly meetings were conducted and issues raised in all the three-forum meeting are listed. Problems identified in the first meetings if not properly addressed by the government will be raised again and this can identify areas of success or failure.

The National Private Public Partnership (PPP) Forum is supported by a series of sectoral sub-committees covering industries that have been targeted as priority areas in the new Industrial Development Strategy. Currently sub-committees have been formed for leather and leather products, textiles, and horticulture. The sectoral sub-committees provide fora for a focused discussion of the conditions and opportunities in that sector.

The Government also recognizes the potentially important role that chambers of commerce and trade associations can play to improve the business environment, and to promote trade and investment. Chambers of commerce, as representatives of the business community, can provide useful feedback on approaches to deal with problems facing private businesses. In addition, they can strengthen private sector capacity by sponsoring entrepreneurship development programs and business incubation services, providing information on promising economic sectors, and organizing seminars, training activities, and exhibitions to display and promote member products. The Council of Ministers and Parliament both approved a Proclamation to restructure the existing operation of the Ethiopian Chamber of Commerce in line with the federal form of government and to support the transition to a market-oriented economy. Moreover, the proclamation was issued with the intent to reinforce the representation of sectoral associations within the respective chambers.

The Trade Practice Proclamation (Competition Policy), now under publication, will regulate anti-competitive practices, and to protect the public from abrupt shocks, it will regulate prices and ensure equitable distribution of certain basic goods and services during times of shortage and irregular supply. The Trade Practice Proclamation (Competition policy) came in to force on April 17,2003. The Ministry is preparing an implementation plan for the secretariat. And list of members of the competition commission has been finalized; Designation of the commission members by the prime Minster will be realized beginning 2004 and some issues which created some confusion in the current law will be amended.

The privatization program, aimed at promoting the private sector's role in commercial activities, was launched in 1994 with the establishment of the Ethiopian Privatization Agency (EPA). Privatization has not progressed as rapidly as originally hoped, due to delays in 
auditing and the lack of serious buyers for large enterprises. As of June 2003, approximately 230 units have been privatized for a total value of Birr 3.1 billion. The number of enterprises brought to the point of sale stands at 256 units. The first phase of preparatory work (due diligence, privatization strategy, asset valuation, audit, financial restructuring, and business valuation) has been completed for 52 enterprises (although valuation for some enterprises needs to be updated as the initial valuation was done more than three years ago) and the first phase of preparatory work for the privatization of another 61 enterprises is now underway. With regard to slow progress in prioritization the government has commissioned a study to find out why there has been a lack of buyers and what is to be done to infuse momentum to the process.

In the areas of export development, measures have been taken to improve access to finance, access to inputs, and access to land and working premises. In order to encourage exporters the government, through the development bank of Ethiopia, has put aside Birr 1.5 Billion at concessional interest rate. The newly introduced value added tax system has relieved all exports from paying value added tax for inputs purchased in the local market to be processed and shipped to export market. This along with the previously implemented export tax incentive schemes will relive exports from paying tax for inputs both purchased in the local foreign markets. The Addis Ababa industrial Estate which was once owned by the Addis Ababa city Administration has been transferred to the Ministry of Trade Industry on December 2002 with the prime objective of providing working premises for exporters. 9 industrial buildings of various sizes were made ready for potential investors. The Industrial Zones cover an area of 10,626 square meters. Some Exporters have already secured working premises.

In addition, 40,000 sq. meter of land is to be leased for exporters at affordable price. Some exporters have already applied for acquisition of land and this is also under process. Earlier steps have already been taken to reduce costs to exporting firms. The Export Duty Incentive Scheme Proclamation (249/2001) outlined a number of schemes to help exporters. The bonded manufacturing warehouse arrangement is designed to let exporters import raw materials and intermediate inputs for export production without having to pay import duties or other indirect taxes. The duty drawback scheme permits the refund of duties paid at the port of entry on goods imported by firms that are engaged in exporting, if certain conditions are met. The voucher based duty exemption scheme is designed to simplify access to duty free imported inputs for export production via use of a MOFED document possessing monetary value to be used as deposit for duties and taxes payable on imported raw materials. A study is currently underway to address the deficiencies of the export guarantee scheme which was confronted with implementation problem.

Regarding the country's accession to WTO, Ethiopia is currently under observer status in WTO. The country has officially applied for accession. One of the most important requirements for accession is the preparation of memorandum on the foreign trade regime. Its purpose is to provide a background information on the process pursued and the laws and regulations issued by the country to conduct foreign trade in goods and services and other foreign trade related activities. The Memorandum on foreign Trade regime is under preparation and the draft will be ready by end of 2003 .

Further, Ethiopia has also recently completed a Diagnostic Trade Integration Study (DTIS). The DTIS represents the first step of a larger program, the Integrated Framework for Trade- 
Related Technical Assistance for Least Developed Countries (or IF Program). The IF Program was designated by the WTO Ministerial Conferences (and reconfirmed in the Doha Declaration) to be the international community's principal mechanism to help developing countries to benefit from the global trading system. The DTIS studies are expected to:

Assess the competitiveness of the sectors that are engaged in (or have the potential to engage in) international trade;

$>$ Analyse the impact of prevailing trade-related policies on poverty reduction; and

$>$ Identify internal and external opportunities for promoting trade and poverty reduction.

The Government is committed to work with the private sector and development partners to implement the recommendations of the DTIS. The IF process is intended to promote coordinated response from partners to the recommendations. 


\section{Development Regarding Crosscutting Issues}

\subsection{HIV-AIDS}

HIV/AIDS poses a major threat to growth and poverty reduction and marks a major source of vulnerability in Ethiopia. To address the threat the government has put in place policy, strategic and institutional framework.

The HAPCO has strengthened its capacity by recruiting additional staff. A program of workshops and seminars has aimed to improve information flow between the national HAPCO and Regional HAPCOs and other stakeholders. A Joint Mid Term Review of the Ethiopia Multi-sectoral HIV/AIDS Project (EMSAP) has been made and offered recommendations for improvements.

A monitoring and evaluation framework has been developed and the preparation of an operational manual is underway. Medical supplies, office equipment, laboratory equipment and kits have been procured and supplied to health facilities. Anti-viral services for AIDS patients have been started in selected and controlled drug stores and health facilities. Prevention of Mother to Child Transmission (PMTCT) service has been started on a pilot basis in four hospitals - Gondar, Dila, DireDawa and Jimma Hospitals. Despite training that has been given, there is still a lack of competence to carry out the demanding tasks of planning, financial management and reporting.

Constraints include delays in reporting and utilizing funds by implementing agencies has hindered implementation. Monitoring and Evaluation is weak at all levels, especially at woreda level. Poor infrastructure (road, telephone, etc.) makes supervision and communication difficult at the community level.

During 2002/03, HAPCO was mainly engaged in coordinating capacity building activities of all implementing agencies, expanding over all government multi-sectoral response \& facilitating and supporting the civil societies, NGOs, GOs, CBOs, FBOs. The major source of fund is the Ethiopian Multi-Sectoral HIV/AIDS project (EMSAP). The Ethiopian MultiSectoral HIV/AIDS Project (EMSAP) funded by IDA was launched as part of the major national response to HIV/AIDS in January 2001.

The overall objective of EMSAP is to reduce the spread of HIV/AIDS epidemic, alleviate its impact and increase access to treatment, care and support for those infected and affected. The project is based on the Government's National Policy on HIV/AIDS and the five years Strategic Framework for the National Response to HIV/AIDS (2001-2005) and premised on the development and expansion of local responses to the epidemic.

The key actors in the implementation of EMSAP are government agencies at federal and regional levels, community based Organizations, NGOs, FBOs and private sector. EMSAP is a unique project that pioneered a multi-sectoral approach in the fight against HIV/AIDS with government leadership and the direct participation of the community and the private sector.

The total amount of EMSAP fund used to finance programs carried out during 2002/03 fiscal year stood at about 69.6 Million Birr. Of the total fund capacity building, government multi-sectoral response, Emergency Fund (Fund used for CBOs, FBOs, Civil Societies, etc), and management and coordination accounted for $21,24,52$, and 3 percent, respectively. 
Achievements in the areas of capacity building and institutional strengthening involve the setting up multi-sectoral implementing mechanisms down from the grass root (community) level to national level. This include the following, among others:

$>$ Establishment of the National HIV/AIDS Prevention and Control Council and HAPCO at national level;

> The establishment of Regional, Woreda and Kebele AIDS Councils and committee;

$>$ Incapacitating most of the offices with qualified professionals, basic equipment, facilities, operational expenses;

$>$ Establishment of HIV/AIDS task forces/focal persons in the 28 federal government agencies and 125 regional government bureaus.

Another area of achievement of the EMSAP relates to rapidity expanding woreda coverage. EMSAP was launched with five pilot woredas from each region in 1993. The over all target was to cover 165 woredas through out the three years life span of the project. However, with improved implementation capacity, it was possible to cover 205 woredas (130\% of the target) and about 5000 kebeles with an estimated population of nearly 22 million. In particular, Tigray and Afar regions have covered the whole of their woredas and kebeles.

The 2002/03 also witnessed enhanced community and other stakeholders' participation. NGOs, FBO, CBOs professional associations and the private sector have been actively involved in the multi-sectoral activities. Community Based organizations like Idirs, Women's and Youth Associations, Anti AIDS Clubs have been intensively working in prevention and care and support activities. Professional Associations like the Ethiopian Public Health Association, Ethiopian Medical Association, Journalist and Teachers' Associations have been playing significant roles. The recently formed National Partnership Forum Against HIV/AIDS and other emerging joint forums of civil organizations are proving to be effective platforms of coordination and have enhanced the coordination role of $\mathrm{HAPCO} / \mathrm{PCU}$.

Other activities in the areas of HIV/AIDS prevention and control and monitoring and evaluation include: development of guidelines and manuals, programmatic performance aimed at increasing awareness and enhanced participation of the public against the fight on HIV/AIDS, increased media coverage, increased involvement of religious leaders and opinion makers to openly advocating on HIV/AIDS,

The preparatory work to launch PMTCT including PMTCT + is completed. The PMTCT guideline is finalized and included in the Policy and Use of Anti Retroviral Drugs (ARD). The national plan for the expansion of PMTCT is made operational. The service, which is jointly sponsored, by UNICEF, USAID, MoF and HAPCO/PCU is now officially launched and initiated in four selected sites professionals are trained; necessary drugs, supplies, and equipment are distributed to each of the selected sites.

\subsection{Population and Development}

The population dynamics of fertility, mortality and migration interact with development processes through their outcomes of population growth and size, age-sex structure and distribution. These in turn have effects on size of production, consumption and savings. The results of such interactions are reflected in the levels of basic needs satisfaction and income, education, health, nutrition and employment statuses of people. 
Realizing the close interaction between population and development, the Government of Ethiopia launched the National Population Policy of Ethiopia in 1993, with the goal of harmonizing the growth rate of population with resource base of the country. The policy calls for reduction in total fertility rate from 7.7 in 1993 to 4 in 2015; increase in contraceptive prevalence rate from 4.4 to 44 percent by 2015 ; and reduction in maternal, child and infant mortality and morbidity rates.

To achieve these objectives four focus areas of population activities have been identified. These were:

(a) Improvement in the quality and scope of reproductive health service delivery;

(b) Population research, data collection, and dissemination;

(c) Expansion and strengthening domestic capacity for training in population;

(d) Expansion of IEC activities and social mobilization.

\section{Improving the quality and scope of service delivery:}

The diversity and coverage of reproductive health service delivery have been expanded through clinical and community based outreach services. Health service points have been required to include reproductive health services as routine tasks to perform. Government hospitals, health centers, clinics in urban and rural areas provide RH services to persons whoo need them. The Government initiated the project "Making Pregnancy Safer"

Private sector hospitals, health centers and clinics also provide RH services to people residing in both rural and urban areas. The number of NGOs providing such services is on the rise. In fact, most of the rural people are served by NGOs established to give such services. Choice of methods has now expanded, with the current mix of contraceptives increasing. Though the contraceptive mix is increasing, it has not expanded enough to meet the needs of persons for various contraceptives, which will contribute, to reducing the level of maternal mortality and morbidity.

\section{Population research, data collection, analysis, and dissemination:}

In the area of population research, data collection, analysis, and dissemination,

$>$ The Demographic Training and Research Center of the AAU had trained 11 students who graduate with M.Sc. degree in Demography. It has also undertaken an important research on population in the SNNPR.

$>$ The Center for Research and Training in Women and Development has conducted a training program on Research in Gender for staff regional offices of population. The Center has also undertaken a number of researches on women and development.

$>$ The Population and Housing Commission Office has undertaken pre-census preparatory activities for the third population and housing census.

$>$ The National Office of Population has provided backstopping mission to the regional offices of population and it has provided training for the regional staff. Regional Offices of Population have conducted research to show the "Demographic and Socio- 
economic Profile," in their respective regions, for use by regional authorities and bureaus.

\section{Expansion and strengthening domestic capacity for training in population:}

The development of domestic capacity for training of high level personnel in demography and population studies is another activity that was given priority attention in the population policy. Accordingly, resources have been allocated to the DTRC and CERTWID to develop their capacities in training personnel in the area of population and development. Several staffs of ROPs have been trained in these centers, and have gained skills in population program management, research methodologies, and in gender, population and development (GPD).

Training on population and development and reproductive health has been integrated in the curricula of the school system. The Institute of Curriculum Development and Research (ICDR) of the Ministry of Education has incorporated population and development, gender and reproductive health issues in the curricula of medical schools, junior college, technical and vocational schools. This has helped to accelerate the integration of reproductive health services in the existing social and health service network.

Several training programs have been organized for teachers, agricultural extension agents, and trade union leaders to create awareness about issues related to population and development, gender and reproductive health. Both the Government and NGOs have been involved in training programs for parliamentarians, community leaders, and people at grassroots levels.

\section{Expansion of IEC and Social Mobilization:}

Efforts have been made to increase popular awareness of issues related to population and development. IEC/Advocacy strategy has been developed and issued for use by stakeholders involved in population activities and for facilitation of community participation in the implementation of population programs and projects. The strategy has been helpful in the systematic use of media channels in influencing behavioral change towards favoring small family size. The behavioral change communication (BCC) efforts have contributed to changes in reproductive behavior. The BCC with the HIV/AIDS pandemic has gained some ground in the community.

Community organizations, NGOs, women and youth groups, school clubs, and enterprises have been used as means of disseminating population IEC materials.

As mentioned earlier, population and family life education has been an integral part of the school curricula at primary, secondary and tertiary levels of the educational system in the country. This has helped in delivering population information and education through the school system.

The agricultural extension training program has incorporated IEC for creating awareness among extension agents. The extension agents in turn have used the population IEC material for creating awareness about population and development issues among the rural people, particularly among rural community leaders and development practitioners. 
Women Affairs Offices at federal and regional levels have also developed and disseminated population IEC materials particularly gender related IEC materials, newsletters, and brochures for creating awareness among community leaders, development agents, and stakeholders.

\subsection{Environment}

The Environmental Protection Authority (EPA) is the lead institution for environmental protection. Major environmental regulatory actions carried out during 2002/03 periods include the following:

\section{Environmental Proclamations Issued}

The following three environmental proclamations have been issued.

$>$ Proclamation to provide for the Establishment of Environmental Protection Organs, issued on $31^{\text {st }}$ October 2002, Proclamation No. 295/2002;

D Environmental Impact Assessment (EIA) Proclamation, issued on $3^{\text {rd }}$ December 2002, Proclamation No. 299/2002;

$>$ Environmental Pollution Control Proclamation, issued on $31^{\text {st }}$ December 2002, Proclamation No. 300/2002

These proclamations are tools to ensure sustainability of poverty reduction interventions in various social and economic development sectors. The core element of the proclamations is to address the problems of land degradation and environmental pollution the most vulnerable victims of which are both the rural and the urban poor. As the country is large and follows a federal system of administrations the proclamations foster a decentralized but coordinated approach to environmental management. Accordingly, it emphasize the necessity of establishing a system that fosters a coordinated but differentiated responsibility among environmental protection agencies at the federal and regional levels and sectoral agencies the mandates of which relate to the environment.

\section{State of Environment Report of Ethiopia Prepared}

The firs state of the Environment Report for Ethiopia was published in August 2003. According to the report, poverty and environmental degradation problems are closely linked. While environmental degradation in most parts of the country exacerbates the poverty situation, poverty has been the driving force for environmental degradation, resulting in a vicious circle.

\section{Studies Conducted}

Different studies have been conducted in various thematic areas that address the environment-poverty syndrome. The Purpose of these studies has been to diagnose the prevailing situation and to point out possible interventions that would address the problem for the improvement of livelihoods of local communities while maximizing environmental enhancement. The major studies carried out include:

$>$ A study of Bush Encroachment in the Awash National Park, and Invasive species in the Rift Valley Areas (Middle Awash);

$>$ Promoting Sustainable Land Husbandry Through Organic Manure Use;

$>$ An Environmental Study in Qutcha Woreda (Gamo Gofa) 
$>$ Study on Wetlands Conducted;

$>$ Global Environment Facility (GEF) Country Dialogue Workshop Conducted;

$>$ Development of Environment Management Plan (EMP) for Ethiopia's Sustainable Poverty Reduction Program (ESPRP)

The objectives of the EMP are to:

- Identify potential environmental impacts of sectoral and cross-sectoral programs and propose mitigation measures.

- Identify monitoring indicators and suggest a monitoring strategy for the follow-up of the implementation of the program.

Environments and Sustainable Dry land Management Program

Ongoing Study on Capacity Building

The World Bank in collaboration with EPA is undertaking a study on institutional analysis. The Authority has facilitated the work of the study mission. The study team has completed its research in the filed.

A half-day consultation meeting was organized by the World Bank mission to exchange ideas on the preliminary findings of the study. Staff members of EPA have participated in the meeting and made contributions towards enriching the draft report. The comments provided to the mission during the consultation meeting are believed to improve the work in line with the TOR of the study. At present, the study mission is compiling the report with a view to giving it to EPA before the end of October 2003.

\subsection{Gender and Development}

The activities discussed earlier in the areas of education, health, water, access road, and agriculture and food security do positively impact on improving the benefits of development to women. As such these need not be repeated here in detail Girls enrolment is steadily increasing. Girls education is key to empowerment. A number of activities by government and NGOs have been carried out to change perception and underscore the important role of women for growth and poverty reduction.

Further more, in order to enhance the living condition of women with low living standard organizing in income generating activities with the view to alleviating their economic and social problems is currently high on the agenda. To achieve these objectives, under the Ethiopian Women Development Fund (EWDF) the Women's Development In initiatives Project (WDIP), which is co-financed by GOE, Italian cooperation and IDA has been established.

Thus, the main objective of the WDIP is to enhance women's empowerment through development intervention by providing financial and technical support, which increase women's opportunities and provide them access in decision-making process.

The project is aimed at covering all regions in five-years time. Currently, the project is underway in the first pilot regions (Addis Ababa, Afar, Amhara and Dire Dawa). In the 
reporting year, the Project has intervened in the second phase five regions Tigray, Oromia, Somalia, SNNPRs and Harari. Therefore, a total of nine regions have been implementing the project activities.

\section{Capacity Building Activity}

With respect to building activities at federal levels focus on providing capacity building technical assistance to the regional WDIP offices.

At the regional level the focus was on awareness creation for woreda and kebele officials, NGOs, youth and women association, etc. and for the community on project implementation procedures, selection processes and role of intermediaries and facilitators. There were also some capacity building training conducted for RCU staff, intermediaries, technical support experts, women groups and facilitators.

With regard to the project implementation, the low disbursement of the fund to the women groups is an indication that the overall annual project performance is far below the planned target. 


\section{$\underline{\text { X. Overview of External Economic Environment for SDPRP Implementation }}$}

\subsection{External Resource Flows}

One of the main financing sources for the Ethiopia's Sustainable Development and Poverty Reduction Program (SDPRP) is expected to be donor support. In this regard, the first major task conducted by the government was to obtain the support and approval of major donors for the whole program. Subsequently, the Ethiopian government together with donors prepared a Consultative Group (CG) meeting in December 2002 to discuss on the Sustainable Development and Poverty Reduction Program and to mobilize the resources required for its full implementation. As indicated by the final pledging session of the $\mathrm{CG}$, donors expressed their full support to the program and promised to raise 3.6 billion USD during the period spanning the years 2003-2005 for the implementation of the Program.

In the past one-year, i.e. 2002/03, several of the pledges expressed during the $\mathrm{CG}$ have started to materialize in the form of framework agreements. Principal among these are the agreement reached between the Government of Ethiopia and the World Bank in the form of the Country Assistance Strategy (CSA) for 2003 - 2005 to provide 1.5 billion USD, and the agreement between the African Development Bank and the Government to provide about 250 million USD during 2002 - 2004. On the bilateral side new agreements were signed during the year between the Ethiopian Government and Italy, Germany, Japan, United Kingdom, Sweden, Netherlands, Ireland, France, Norway, the Czech Republic and Norway.

Some of the framework agreements were translated into project-based commitments during the fiscal year. The combined value of such agreements amounted to USD 1050.67 million during 2002/03 fiscal year, registering marginal increase over the USD 1032.35 million secured during FY 2001/02. On the other hand, actual flow of development resources during FY 2002/03 witnessed significant decline amounting to USD 684.05 million compared to previous year's level of USD 881.19 million (excluding emergency assistance). This shows that overall actual disbursement (from

All sources) declined by about 22 percent.

The exhibited $22 \%$ decline in disbursements occurred for various reasons. Table 1 below indicates the variations in disbursements between the two years (2002/03 versus 2001/02) by major donors.

As depicted in Table 15, the shortfall in disbursements during 2002/03 FY is to a larger extent accounted for by multilateral sources. One reason for the shortfall is decline in the number of quick disbursing projects. For instance, with respect to IDA, quick disbursing projects such as the National Fertilizer Project and Emergency Demobilization and Reintegration Project allowed the release of USD 87.9 million during FY 2001/02, as compared to total disbursements of only USD 26.7 million during the following year from these same projects. Similarly, the Emergency Rehabilitation Support Credit (ERSC) enabled to disburse relatively larger amount of resources in EFY 2001/02 compared to disbursements from the Ethiopian Structural Adjustment Credit (ESAC) in EFY 2002/03.

The disbursement gap between the two years regarding ADB's assistance to Ethiopia is basically as a result of one project namely Structural Adjustment Credit, which in FY 2001/02 disbursed USD 53 million from the credit alone while there was no disbursement at all during the following period. Although a second tranche disbursement of to USD 26 
million was expected in FY 2002/03, it took much longer time to meet the second tranche conditions. This disbursement is now planned for FY 2003/04. A fertilizer project also contributed for greater disbursement from ADB in EFY 2001/02.

On the bilateral donors side, aggregate disbursements in EFY 2002/03 for 12 major donors recorded a decrease of 1.23 percent compared to similar period of the preceding year. Some of the increases in disbursements are associated with new assistances such as budget support from UK and the commencement of works under Germany financed Addis - Gedo road project. The fall in disbursements from Ireland is associated with the termination of activities by Irish Aid in the SNNP region while falls in disbursements from Japan are a result of decrease in ODA provided by the country recently.

Table 17: Disbursement Comparison by major Donors, in millions of USD

\begin{tabular}{|c|c|c|c|c|c|c|c|}
\hline \multirow[b]{2}{*}{ Donor } & \multicolumn{3}{|l|}{ 2001/02 } & \multicolumn{3}{|l|}{$2002 / 03$} & \multirow{2}{*}{$\begin{array}{c}\text { Change } \\
\text { over } \\
2001 / 02 \\
\text { In } \%\end{array}$} \\
\hline & Loans & Grants & Total & Loans & Grants & Total & \\
\hline \multicolumn{8}{|l|}{ Multilateral } \\
\hline IDA & 437.81 & & 437.81 & 361.85 & 0.41 & 362.26 & -17.26 \\
\hline $\mathrm{ADB}$ & 79.96 & 0.61 & 80.57 & 19.72 & 0.78 & 20.50 & -74.56 \\
\hline $\mathrm{EU}$ & & 56.22 & 56.22 & & 68.15 & 68.15 & 21.22 \\
\hline IMF & 51.90 & & 51.90 & 13.80 & & 13.80 & -73.41 \\
\hline WFP & & 31.51 & 31.51 & & 31.89 & 31.89 & 1.21 \\
\hline UNICEF & & 20.16 & 20.16 & & 23.40 & 23.40 & 16.07 \\
\hline UNDP & & 13.06 & 13.06 & & 7.11 & 7.11 & -45.56 \\
\hline EIB & 19.14 & & 19.14 & 15.14 & & 15.14 & -20.90 \\
\hline Other Financial Institutions & 19.92 & 0.94 & 20.86 & 8.22 & 0.63 & 8.85 & -57.57 \\
\hline Other UN Agencies & & 5.27 & 5.27 & & 2.54 & 2.54 & -51.8 \\
\hline Total Multilateral & 608.73 & 127.77 & 736.5 & 410.51 & 134.91 & 545.42 & -25.94 \\
\hline \multicolumn{8}{|l|}{ Bilateral } \\
\hline Sweden & & 6.76 & 6.76 & & 14.16 & 14.16 & 109.47 \\
\hline Italy & & 29.30 & 29.30 & & 22.50 & 22.50 & -23.21 \\
\hline Germany & & 9.73 & 9.73 & & 17.53 & 17.53 & 80.16 \\
\hline UK & & & 0 & & 14.05 & 14.05 & \\
\hline Netherlands & & 8.81 & 8.81 & & 7.26 & 7.26 & -17.59 \\
\hline Japan & & 33.49 & 33.49 & & 15.94 & 15.94 & -52.40 \\
\hline USA & & 29.40 & 29.4 & & 30.84 & 30.84 & 4.9 \\
\hline Ireland & & 23.36 & 23.36 & & 9.83 & 9.83 & -57.92 \\
\hline Finland & & 1.24 & 1.24 & & 0.3 & 0.3 & -75.81 \\
\hline France & & 1.05 & 1.05 & & 4.12 & 4.12 & 292.38 \\
\hline Norway & & 0.29 & 0.29 & & 0.52 & 0.52 & 79.31 \\
\hline Austria & & 1.26 & 1.26 & & 1.58 & 1.58 & 25.4 \\
\hline Total Bilateral & & 144.69 & 144.69 & & 138.63 & 138.63 & -4.19 \\
\hline Grand Total & 608.73 & 272.46 & 881.19 & 410.51 & 273.54 & 684.05 & -22.37 \\
\hline
\end{tabular}

Source: Multilateral and Bilateral Cooperation Departments of MOFED

Regarding the composition of resource flow between loans and grants, the general direction in the past year has been an increase in the level of grants, both in the form of new commitments and disbursements, as compared to the preceding year. In 2002/03, about 40 percent of disbursements were grants as compared to 30 percent grant for the previous year. The amount of grant resources disbursed in 2002/03 from multilateral sources has increased 
over the previous year. Similarly, the grant composition in new commitments during the past year increased in both absolute and relative magnitudes.

In summary, much effort is needed to raise per capita resource flow to Ethiopia from the current level. It is also recognized that quick disbursing arrangements provide better possibility for raising the disbursements level to the country compared to typical project based arrangements. It is equally important to work in the areas of improving the composition of inflow in favor of grants to reduce the debt burden of the nation while at the same time meeting the resource requirement. The pledges of the past year are encouraging results in this direction. Ultimately however, the pledges have to be translated into real commitments, and more importantly disbursements.

\subsection{Donor Harmonization Agenda}

The global harmonization agenda is another instrument, which supports the poverty reduction efforts of Ethiopia. In recognition of the benefit, the Ethiopian Government has been spearheading initiatives to dialogue on the need for aligning with SDPRP as well as procedure harmonization on the part of donors. A key development in this regard is the workshop organized by the Ethiopian Government in October 2002 to discuss on issues of harmonization with the local donor community. One of the major achievements of this workshop was better recognition by donor community of the burden imposed by the existing aid delivery arrangement. The Government also expressed its clear preference for more flexible aid delivery instruments such as direct budget support. In this respect, the supportive efforts of the SPA team are very much appreciated.

The Consultative Group (CG) meeting of December 2002 was also instrumental for the wider discussion on issues of harmonization and alignment with donor partners. The approach was innovative compared to the traditional way of focusing on resource mobilization and policy dialogue during CGs. As indicated by the final joint press release given by Government and the international donor community, delegates endorsed a new partnership with Ethiopia that aims at increasing levels of assistance, while improving the effectiveness and speed of aid delivery. Donors reaffirmed their commitment to enhance their cooperation with government in line with the priorities detailed in the Government's SDPRP, and agreed to increasingly align their procedures with Government systems, while supporting the strengthening of these systems to increase absorptive capacity.

Several developments have been witnessed which in one-way or another advance the harmonization agenda in Ethiopia in the past year. Some of the major ones include:

As recommended by the October 2002 workshop, a Government - Donor Taskforce on Harmonization (HTF) was created in November 2003. The main task of the HTF it to prepare a harmonization agenda for Ethiopia, draw an action plan, support the implementation of the action plan, and monitor progress. The HTF has prepared the first draft of the action plan.

Enhanced dialogue architecture was finalized in April 2003, as per the agreement reached between the Government and donors during the 2002 CG meetings. The HLF has three overall aims: (1) to enable on-going Government-donor dialogue on implementation and monitoring of the SDPRP. (2) to enable on-going dialogue on Government-donor 
relations and progress with harmonization. (3) to provide a forum for regular discussion of high-level policy issues. The HLF will also be the key structure for enabling mutual accountability and better policy dialogue;

Few federal institutions together with donors providing support in those areas are moving forward with measures that facilitate better harmonization. Some such cases include: (1) Donors supporting RSDP II, (ADB, DFID, EU, Germany, IDA, Irish Aid, Italy, Japan, NDF and SIDA) are working together to harmonize their procedures including financial reporting and auditing, procurement methods, etc. (2) Donors supporting the MoE for the Teachers Training Program are working to pool their assistance to the program. (3) Donors supporting the $\mathrm{MoH}$ are working together to pool funds for Technical Assistances required for the HSDP II;

\subsection{New Instruments of Financing}

Donors acknowledged the potential benefits of a gradual move towards more flexible instruments of aid delivery such as direct budget support and sector support as one important process during the Consultative Group (CG) meeting. In this regard, a budget support group has been formed from the donor community in Ethiopia.

Donors such as the European Union and DFID have taken the lead in this regard. During EFY, the European Union disbursed Euro 25 million in the form of budget support, thereby taking the lead in mobilizing resources through the new instrument of DBS. Similarly, the DFID was able to work on the same line and released GBP 10 million in the form of direct budget support during the period. The World Bank has introduced Poverty Reduction Support Credit (PRSC) as direct budget support instrument and is currently processing PRSC I amounting to USD \$150 million.

\subsection{Debt Strategy \& Sustainability Analysis}

Ethiopia is classified as one of the Heavily Indebted Poor Country (HIPC) and hence has been entitled to receive debt relief under HIPC Initiative. Actual debt service in 2002/03 was US\$ 83 million, which is equivalent to $7.7 \%$ of exports.

In November 2001, Ethiopia was declared eligible for HIPC debt relief and reached its HIPC Decision Point. At that time, the amount of debt relief needed to bring the country's debt to a sustainable position was calculated to be USD 1,930 million in nominal terms or USD 1,275 million in present value (PV) terms. Since November 2001, Ethiopia has been receiving interim assistance from some of its major multilateral creditors, mainly the World Bank (IDA), African Development Bank (AfDB/AfDF), International Monetary Fund (IMF) and EU, as well as from its Paris Club bilateral creditors. The country is expected to receive significant debt relief in the form of stock reduction when it reaches its HIPC Completion Point soon

Ethiopia has suffered from the following four exogenous shocks since the Decision Point in November 2001: 
A decline in international discount rates (Commercial Interest Reference Rates - CIRR) used to calculate the net present value (NPV) of debt has pushed up Ethiopia's present value of debt;

A decline in the value of the US dollar compared to other currencies has pushed up present value and debt service in relation to exports;

$>$ A shock in coffee prices has contributed to the increase in the debt burden, or had there been no decline in coffee prices, the increment in the NPV.XGS ratio would have been less.

$>$ The severe drought in 2002/03 has reduced agricultural production and exports, and necessitated large food imports, which increased the balance of payments financing needs.

At the time of Ethiopia's Decision point, its NPV/XGS ratio at Completion point (2002/03) was projected to be $173.5 \%$ this projection was based on the debt stock, exchange rates and CIRR rates as of June 2001, and on balance pf payments forecasts that included rising coffee export prices and no allowance for drought. However, taking the changes in CIRR and exchange rates, actual export earnings and the effect of the drought into account, the NPV/XGS ratio has increased to $220.8 \%$. As a result, it is evident that Ethiopia has suffered from external shocks, which have increased its present value/export ratio and, therefore, changed its economic circumstances compared to the Decision point.

The current projected level of financing is inadequate to allow Ethiopia to reach the MDGs. Ethiopia, therefore, requires higher spending and external financing in order to reach its SDPRP targets and MDGs. 


\section{Overview of the SDPRP Monitoring and Evaluation (M\&E) Systems}

\subsection{Objectives}

The Monitoring and Evaluation (M\&E) System is intended to:

(a) Provide a good understanding of the nature and distribution of poverty in all its dimensions, and monitor changes in the level and incidence of poverty;

(b) Monitor implementation of the SDPRP and identify problems as they emerge;

(c) Assess whether implementation of the SDPRP is having the intended effect on poverty.

The M\&E System should provide transparent and broad-based monitoring and evaluation of the SDPRP based on high quality data and analysis, so that progress can be tracked and assessed, and accurate information can be delivered in a timely fashion, in order that adjustments and corrective measures may be taken where necessary. It will establish the framework for a transparent process by which the Government and its development partners can undertake a shared appraisal of results and ensure smooth release of external budgetary support.

The M\&E System will take into account the multi-sector approach to achieving national growth and poverty reduction objectives, as well as recent implementation of the decentralization of responsibilities towards regions and woredas. It is designed to track the progress of key indicators in several sectors of the economy at the unit of observation that is consistent with the structure of intergovernmental responsibilities.

The system is expected to:

(a) Monitor input and process indicators across levels of government, including public expenditure and progress on reforms;

(b) Monitor output indicators on access to education, health and infrastructure, and other relevant variables, at various levels, including household, woreda, regional and national;

(c) Monitor overall developmental outcomes and final objectives, such as poverty, educational achievement and health status;

(d) Learning -by-doing, linking indicators of the reform process to outcome improvement;

(e) Evaluate key programs and policies in reaching desired objectives.

A detailed proposal to implement specific elements of the M\&E action plan has been prepared by the Ministry of Finance and Economic Development (MOFED) to submit to the Development Assistance Group (DAG) for funding. This proposal aims to contribute to the development of the monitoring and evaluation system of SDPRP and MDGs. It proposes a number of activities to be implemented by the Central Statistical Authority and the Welfare Monitoring Unit at the Ministry of Finance and Economic Development whose purpose are (a) to create necessary evidence, both qualitatively and quantitatively, at low levels of aggregation on welfare outcomes and inputs, via new data collection, integration of existing data and advanced analysis of all available data and (b) to enhance the broad and fast dissemination and usage of data and findings related to welfare outcomes and inputs to all stakeholders. The activities are a subset of the essential activities for the overall Monitoring and Evaluation of the SDPRP with immediate need.

\subsection{The Institutional Framework}

The Welfare Monitoring System that has been in place since 1996 has been reoriented and revitalized to meet the monitoring and evaluation requirements of the SDPRP. To this effect, 
the government is revitalizing and re-orienting the functioning of the existing structure in the light of the monitoring and evaluation requirements of the SDPRP implementation. The institutional set up that used to be in place for implementing the WMS program and the latter structure set up for the formulation of the SDPRP through participation of the various stakeholders (Government, Private sector, Donors, NGOs and civil society groups and the primary stakeholders, the poor themselves) serves as a basis for the institutional structure for monitoring and evaluation of the SDPRP.

The Welfare Monitoring Committee (WEM COM) has been formulated which comprised of high-level government officials of key poverty oriented federal ministries and institutions. This committee oversees the overall SDPRP monitoring and evaluation activities and is being chaired by the Minister of the Ministry of Finance and Economic Development (MOFED). The WEM COM approves work plans on monitoring and evaluation of SDPRP and reviews annual progress reports to be prepared by the Welfare Monitoring Unit of MOFED. The WEM COM also have a technical arm called Welfare Monitoring Technical Committee (WEM TEC) entrusted with supplying the requisite pertinent data (information) and providing technical advice to the WMU in the course of monitoring and evaluation of SDPRP implementation. The Head of Economic Policy and Planning Department (EPPD) of MOFED in which the WMU is currently mainstreamed is chairing the WEM TEC.

The Government of Ethiopia established a Welfare Monitoring System (WMS) in 1996 to monitor the effect of economic policy on social outcomes. Key institutions are the Welfare Monitoring Unit (WMU) in the Ministry of Finance and Economic Development (MOFED) and the Central Statistical Authority (CSA). The Welfare Review Committee provides oversight. The System delivers an Annual Review of Social Trends and Welfare, policy papers on key issues, and workshops and seminars to promote policy discussion and disseminate results.

The WMU is in charge of inter-ministerial coordination, maintenance of the national socioeconomic database, policy analysis and advice. It is the anchor for all poverty monitoring and evaluation activities, and is responsible for compiling and analysing data collected by other institutions in order to provide performance reports on SDPRP implementation, for commissioning relevant research, and for disseminating the findings. Its activities are aimed at ensuring that there is transparent and broad-based monitoring and evaluation of the SDPRP based on high quality and widely used data and analysis. The WMU relies on a variety of sources of data to fulfil its monitoring tasks. As a key user, it is responsible for ensuring that relevant data are collected for these purposes. WMU activities fall in two categories: (a) ensuring the collection of the necessary data, both quantitative and qualitative, on welfare outcomes, and the inputs to achieve these outcomes. and (b) dissemination aiming to ensure full use of findings by different layers of government and other stakeholders.

The Central Statistical Authority (CSA) is the main data collection authority in Ethiopia. It has carried out successfully a complex plan of surveys and censuses over the last fifteen years, including the population and agricultural censuses, the Household Income Consumption and Expenditure Survey (HICES), the Welfare Monitoring Survey (WMS), the Health and Nutrition Survey and the Labour Force Survey. It has recently completed its second Medium Term National Statistical Programme (MTSNP) (2003-2008), and is currently in the process of institutional strengthening. CSA's poverty/welfare related forth- 
coming surveys and censuses activities as per its Medium term National Statistical Program (MTNSP) are depicted in Annex 4 of this document. Among this activities the government is committed to conduct the Household Income, Consumption and Expenditure survey for the third time and the Welfare Monitoring survey in the year 2004 to update the poverty profile of the country and at the same time to strengthen the monitoring and evaluation system of SDPRP implementation.

Alongside the CSA, several line ministries collect socio-economic data needed to monitor SDPRP implementation, mainly from administrative sources. The sectors most relevant for monitoring progress are education, health, water, roads, and agriculture. In the cases of health and education, for example, data are collected at the level of the facility and progressively passed on to the top levels of the hierarchy. Thus, each poverty-oriented sectors has got its own monitoring and evaluation systems

Sectoral monitoring systems feed data into the national welfare monitoring system. The monitoring and evaluation of sector development programs feed in to the overall national welfare monitoring system. Sectoral monitoring systems are linked to their counterparts at sub-national level monitoring systems through joint steering committees and reviews. Nonstate actors are also involved in the various reviews. For instance, in the case of health and education the joint review committee is comprised of a combination of different stakeholders in the sector i.e. regional bureaus, donor community, NGOs and CSOs, etc. The same is true for other sectors.

At the federal level, the Ministries of Capacity Building, Federal Affairs, and Finance and Economic Development as well as the Federal Civil Service Commission play important roles in monitoring (i) key administrative systems and structures, (ii) capacity building and reform activities, and (iii) institutional quality. The M\&E Department of the Ministry of Capacity Building (MCB) is charged with monitoring public sector capacity building programs. Other offices within $\mathrm{MCB}$ are responsible for monitoring their own capacity building activities. For example, the Civil Service Reform Coordinating Office tracks progress on the CSRP, while the Program Offices for District Level Decentralization and ICT track the progress of their own capacity building and institutional reform activities.

The Federal Civil Service Commission (FCSC) is responsible for implementing civil service rules and regulations, preserving the integrity and professionalism of the service, and monitoring personnel management practices (recruitment, transfer, promotion, and termination) as well as structural aspects of civil service management (for example, job grading and salary levels). In light of recent legal and regulatory initiatives to devolve the personnel management function in the civil service to the line ministry/bureau level, the monitoring role of the FCSC has taken on greater significance.

The Ministry of Federal Affairs (MFA) has monitoring responsibilities for urban jurisdictions and municipalities. The Urban Development Capacity Building Office within the MFA monitors municipal restructuring, urban land management, and other capacity building initiatives relevant to the urban development agenda within the SDPRP.

The Ministry of Finance and Economic Development (MOFED) oversees macro-fiscal management issues and monitors expenditure and financial management reforms across tiers of government as well as monitoring routine financial management practices related to budget formulation and execution (including cash management, internal audit, etc.). MOFED 
also is responsible for producing and coordinating data on inputs. Revenue data and macroeconomic projections are needed to derive resource envelopes for planning. Budget and expenditure data on poverty reduction programs are needed to establish the effectiveness of policy instruments and make decisions on future budget allocations.

At the regional level, responsibilities for monitoring crosscutting capacity building programs, financial management rollout, civil service management, and urban development, are dispersed across the bureaus of capacity building, finance, civil service, and urban management. A civil service reform office has been established within each regional capacity building bureau to support the monitoring of CSRP implementation. At the local or municipal level, the capacity building and finance offices replicate monitoring structures at higher levels.

\subsection{The Functioning of the Monitoring and Evaluation System}

Implementation of the M\&E System involves the following components:

(a) Determining what needs to be monitored;

(b) Building an integrated data management system;

(c) Developing a medium-term research agenda;

(d) Strengthening the environment for performance-based decision making;

(e) Strengthening participatory monitoring, dissemination, and feedback;

(f) Strengthening institutional capacity.

To determine what needs to be monitored, the government is finalizing the SDPRP policy matrix following a logical framework approach. The matrix forms the basis for intergovernmental agreements of major outputs and outcomes to be achieved, and provide the basis for the design of the M\&E system. The matrix:

$>$ Spells out the links between policies, allocated inputs, expected outputs, and outcomes needed to achieve the objectives of the government program;

$>$ Identifies indicators to monitor inputs, outputs, outcomes and objectives;

$>$ Sets benchmarks and targets against which to measure progress;

$>$ Specifies sources of data and responsibility for monitoring; and

$>$ Identifies constraints and risks.

Much of the information required for monitoring and evaluation already exists, but is scattered across government, as well as outside the government system. The integrated data management system (I-MIS) will include administrative information from all relevant sectors (education, health, water, roads, agriculture, food security, public sector reform and capacity building, private sector development, macroeconomic and budget) at the woreda, regional and national levels. The design of the system will give the government both vertical and horizontal monitoring capacity, strengthen its ability to identify problem areas and low performers, and improve its capability to affect success. I-MIS will include information on the adoption and implementation of reforms, and will be able to integrate information from survey and census data.

Construction of the database will require substantial support. It will require information technology support as well as assistance to identify and integrate different data sources, including administrative data, data from household surveys, and other sources. The 
development of I-MIS is not just a technical, IT project, but will require substantial work to establish common standards for reporting, improved flows of information and the critical resolution of inconsistencies and gaps in available data.

Analysis of administrative data suggests that the best short-term strategy for developing an inter-sectoral data system is to strengthen current MIS systems in each sector, establish common standards and practices, and merge the systems at the federal level. Data collection mechanisms have been established separately by each line ministry or agency and differ across both in reliability of data and level of capacity building needed to strengthen the flow of information to ensure that federal agencies have access to quality data from the woreda level. Capacity building efforts will have to be directed to regional and local authorities to improve data collection, compilation, and systematisation.

Survey data will be used for microeconomic analysis (e.g. determinants of poverty, returns to education, agricultural productivity) and to undertake impact evaluation studies to estimate the effects of public policy. Independently collected survey data will also be used to run consistency checks on administrative data. Survey data may help the government identify patterns of misreporting in the administrative data and repair malfunctioning administrative reporting. Other sources of data include qualitative assessments such as the participatory poverty assessments, consultations with the poor and the regional PER initiative. Several qualitative NGO- and project-specific data collection efforts are in place at regional and local levels. In addition, selected woredas will undertake client satisfaction surveys, as part of the Capacity Building for Decentralized Service Delivery Project.

The Government's medium-term research agenda will be developed in consultation with interested partners and with the support of the Ethiopian research community. The research agenda will put forth the Government's priorities for policy analysis and evaluation, particular in areas that are key to the achievement of SDPRP targets. The impact evaluation component of the research agenda aims to assess the effectiveness of key government policies and programs in reaching desired objectives, in order to serve as a learning tool to improve government programs. Specific areas of research to be considered relate to the impact of:

$>$ Decentralization on educational and health outcomes;

$>$ Woreda capacity building on woreda performance;

$>$ Agricultural extension on agricultural incomes;

$>$ Food aid on food security and grain prices;

$>$ Agricultural credit on technology adoption, agricultural input utilization and risk.

WMU plans to establish a research fund to commission research to shed light on factors underlying achievement of SDPRP indicators and MDGs, and to gain deeper insights in the geographical diversity of poverty and welfare. Possible research themes include the construction of poverty profiles for specific regions, integrating household survey data with administrative and other data; studies on aspects of welfare and poverty outcomes, such as the determinants and regional variability in school enrolment, including gender dimensions; further studies to understand factors underlying change in poverty over time; and studies on vulnerability to shocks, etc. 
For monitoring and evaluation to be effective, a sensitisation campaign will be implemented to institutionalise monitoring and evaluation as a management tool including for SDPRP and MDGs across different levels and sectors of government, and to underscore the decentralized nature of decision-making. The campaign will explain the aims, purpose, and use of monitoring and evaluation systems, as well as the delivery of training and technology for regional and sub-regional governments.

To ensure the availability of all possible quantitative evidence relevant for poverty monitoring, the CSA will develop an integrated electronic database of all available survey data, other data, and associated data documentation, for internal purposes within the CSA as well as for other government departments and other stakeholders. This database, referred to as the Ethiopian Socio-economic Database, will be complementary to the Integrated Management Information System (I-MIS).

\subsection{Costing Implementation of SDPRP Monitoring and Evaluation System}

To strengthen and sustain the SDPRP M\&E system a number of activities are also carried out. The SDPRP M\&E action plan is prepared with the technical assistance from the World Bank. Apart from this, the key responsible unit of the SDPRP M\&E, the Welfare Monitoring Unit (WMU) and the key data supplier for the welfare outcome information in Ethiopia, the Central Statistical Authority (CSA) have Jointly prepared and submitted a proposal entitled" Strengthening Data Collection, Analysis, and Dissemination on Poverty Monitoring and the MDGs" to the Development Assistance Group (DAG).

This proposal aims to contribute to the development of the M\&E system of the SDPRP. The proposal has detailed activities envisaged by the WMU and CSA and detailed budgets for 2003/04, 2004/05 and 2005/06. The total financial support requested by both the WMU and the CSA stood at about US dollars $11,559,000$, of which $\$ 9,321,000$ is requested by the CSA and $\$ 2,238,000$ by the WMU.

Technical assistance and consultancy services are requested for the following activities:

At the CSA: the CWIQ survey methodology, the development of the ESED, elements of the development of a dissemination strategy and (possibly) the collection of income data in the HICE.

$>$ At the WMU: the implementation of the PPA and the Poverty Mapping study, the development of the I-MIS, training activities for analysis, management, training and dissemination.

As indicated in the SDPRP document the government is committed to undertake the Participatory Poverty Assessment (PPA) in order to complement the quantitative analysis of poverty. As per the commitment the WMU has prepared the technical proposal and the study design, to undertake the Participatory Poverty Assessment (PPA). 


\section{Challenges and Prospects in SDPRP Continued Implementation}

During 2002/03 the Government has been carrying out measures to reduce poverty in the context of SDPRP. These include measures relating to agricultural reform, food security, capacity building, civil service reform, and the urban development, export promotion, strengthening of the existing legal and regulatory framework, and supporting private sector development. The government is also implementing sector programs to enhance human development. Despite the Government's considerable efforts, the development challenges that the country faces are formidable to realize its SDPRP objectives.

The SDPRP in its first year of implementation has seen challenges in terms of external shocks-drought and TOT loss leading to decline in overall growth. Drought has led many people into destitution. So is the continued decline in coffee price depressing economic activities in coffee growing areas, defeating the very efforts of growth and poverty reduction.

The SDPRP still provides conducive platform for growth and poverty reduction in Ethiopia. Accordingly, the following highlights the opportunities and challenges in continued SDPRP implementation.

\section{a) Ensuring Rapid and Sustainable Economic Growth}

Ensuring rapid and sustainable economic growth is one of the formidable challenges in the endeavour towards achieving SDPRP objectives. To address this problem, the Government will continue implementing the structural reforms by accelerating its pace of implementation in the areas of agriculture and rural transformation, private sector development, and urban development and management. The growth Strategy and challenges include, among others:

$>$ Rural focused agricultural-led economic growth: This will be complemented with aggressive promotion of private sector for the growth of micro, small and medium enterprises as well as urban based agro-processors and exporters.

$>$ The significance of non-agricultural sectors: Besides its firm commitment to ensure agriculture to serve as the main engine of growth, the government recognizes the significance of non-agriculture sectors for sustained growth and poverty reduction. The issuance of the white paper on Industrial Development Strategy that takes the private sector as the key actor for the realization of export led industrial development of Ethiopia. Export support packages has also been developed and began its implementation. The institutional transformation through the CSRP to overhaul service delivery and reduce transaction costs to the private sector has gathered momentum during the year. Major actions have been implemented to bring about urban dynamism as growth centers to support sustained rural transformation. All of these show the continued firm commitment to enable private sector development in Ethiopia.

$>$ Rural infrastructure investments is also essential to stimulate agricultural-led economic growth, service the chronically food in secure, provide health and education services, and over all meet broader interests of society. Further, in addition to rural roads improvements information infrastructure, will play an important role in the future performance of rural Ethiopia; 
$>$ Once again the drought emergency of 2002/03 has put pressure on resources and management capacity. Progress cannot be taken for granted due to ever-present shocks- internal and external. It clearly demonstrated the urgency to continue addressing the structural problems of the Ethiopian economy - transforming smallholder subsistence agriculture to smallholder market driven commercial agriculture. Breaking the dependence of Ethiopia's agriculture on rain in a major way through enhanced water resource utilization through a range of options - water harvesting, small-scale irrigation etc.

$>$ Given the significance of smallholder farmer and pastoralists, it is critical to enhance the participation of smallholder in the market as producers and consumers. Continuing to strengthen agricultural marketing is critical.

$>$ Land tenure security: This is an important government policy. In order to ensure tenure security regional governments are taking necessary measures with Swedish (SIDA) assistance. In this regard, the Amhara national regional state has initiated issuance of land certificates backed by a cadastre. Similar efforts are taking place in Tigray National Regional State. The federal government is planning to review this experience to scale up land certification in a cost-effective manner.

Much needs to be done to promote technical advancement in agriculture for smallholders: the challenge here is new cost effective mechanisms for generation and dissemination of new technologies. The regional and agro-ecological diversity while an asset on the other hand adds to the challenge.

\section{b) Enhancing Capacity Building to Improve Performance}

Implementation capacity continues to constrain the performance and the ability of the government and the private sector. During 2002/03 the Government is operational zing the District Level Decentralization program (DLDP) aimed to devolve power to districts, promoting accountable and responsive local government and enhancing democratic participation.

All regions have accompanied this second wave of decentralization with programs to build capacity in the districts. Currently, the Government is integrating the decentralization and capacity building program through the preparation of PSCAP actions plans. PSCAP will seek to build capacity for improved public service delivery by supporting the deepening of civil service reforms, deepening district level decentralization; improving urban management and reinvigorating duties sector institution.

Decentralization has started operating at Woreda level since the on set of the 2002/03 FY. Obviously, the process is not without transitional difficulties. The first difficulty was the mismatch between what some Woredas got through the block grant and their existing obligation. To overcome the mismatch additional transfer mechanisms were introduced to manage the transition in a practical manner. There are also indications for refining assignment of responsibilities between regions and Woredas. Fiscal reporting also experienced some delay. The process also brought out the urgency of capacity building to realize the objectives of devolution to Woredas. Given the fundamental devolution that took place, it is understandable and is expected to face short-term constraints. Overall, however, the process is being managed well, and when problems are faced, Regions are handling them 
in a flexible and practical manner. Since the process is evolving, continuous assessment will be made to identify problems and take corrective measures.

\section{c) Breaking the Cycle of Food Security Crisis}

One of the serious consequences of the structure of the economy is the problem of food insecurity. The extent of the food insecurity has become alarming. As much as 45 percent of the population is affected during drought years. The serious and accelerating problems of food insecurity in Ethiopia are now considered a national security threat. So breaking the cycle of famine has remained one of the formidable challenges towards poverty reduction in Ethiopia.

In addressing the challenges of food insecurity in Ethiopia, a consultative process has been undertaken to strengthen the partnership between the Government and its development partners. The response is embodied in the Food Security Program Produced by the New Coalition for Food Security in Ethiopia. It marks a paradigm shift in the design and implementation of the program.

It is premised on the conviction that the main resources are that of the labor and land of the farmers as the basis for the development of the rural communities. Government and donors' resources will complement the resources of the food insecure households to sustainably move out of food insecurity and poverty. This in turn calls for a major change in the delivery mechanism of the complementary resources - government and donors.

The purpose of the program is to drastically reduce food insecurity faced by vulnerable Ethiopian households. Its five-year goal is to attain food security for five million chronically food insecure people, while, at the same time, improving and sustaining the overall food security of an additional ten million people.

\section{d) Enhanced Human development}

In Ethiopia, the human development issue is among the lowest in the world and even in subSaharan Africa. The education system has expanded rapidly since 1994, but is increasingly unable to sustain the expansion without compromising the quality of schooling conditions. While gross enrollment rates at the primary level including that of girls have increased rapidly, survival rates beyond Grade 1 remain weak and hence primary completion rates have also not experienced the expected rate of increase. Demand side interventions to address reasons for non-enrollment and dropouts have to be sufficiently explored. The low planning, management and implementation capacity, at all levels, especially woreda level are the major constraints facing the implementation of the second Education Sector Development Program (ESDP II).

Regarding Health, potential health coverage of government health facilities has increased while utilization rates are still low and even decreased marginally in recent years, with immunization and antenatal care provision rates among the lowest in sub-Saharan Africa. Given the low coverage rates and likely constraints, the government refocuses on implementation of Health Extension Package (HEP) aimed at effective prevention and control of communicable diseases with active community participation. Severe human resource constraints, especially of highly skilled health personnel, particularly at district and 
operational level limit the quality and coverage of health care, and shortage of resources mismatch the requirement of the planned activities in the HSDP.

While the SDPRP recognizes the importance of addressing HIV/AIDS in a comprehensive way, there is a lack of reliable information or a clear M\&E system to assess progress. Absorptive capacity for HIV/AIDS-related funding is limited, and disbursements are lagging behind the amounts envisioned by the SDPRP.

\section{e) High investment in Infrastructure}

Infrastructure investment is essential to stimulate and promote economic growth. Inadequate infrastructure is an indicator of the inability of the poor to access to social services like education and health and also other facilities. Lack of access to road network limits the communities from market participation and constrains their economic opportunities and then contributing to inability to strengthen human capabilities. Telecommunication, electricity and other infrastructural services should also be given much attention in order to ensure rapid growth and poverty reduction.

\section{f) Public Expenditure and Management}

Total public spending in Ethiopia has increased substantially in recent years (from $24 \%$ of GDP in 1997/98 to 35\% in 2002/03); resources have been reallocated from military spending, and aid inflows have increased. The government has demonstrated clear priorities in allocating this new spending with relatively large increase for poverty-oriented sectors.

The expenditure requirement confronting the government, to provide even minimum levels of social services and infrastructure, is enormous. Very large increases in spending would be required, implement all of the currently proposed SDPRP programs, and to reach Millennium Development Goals. Even if the government is doing its best to solve the problem, through enhanced domestic resource mobilization there is still a gap which needs to be filled. As the 2002/03 public expenditure Review, (just completed, not reviewed) puts in perspective, refers to as fundamental contradiction the gap between the huge needs and the limited capacity to finance those needs. Managing this contradiction is a major challenge for the years to come to achieve both state and structural transformation needed for the country to bring faster and equitable economic growth for breaking the poverty trap and sustain poverty reduction.

\section{g) External Economic Environment}

The Government's effort for achieving its SDPRP objective is also constrained by the external environment. The performance of exports during the 1990s indicated a sign of recovery from the level recoded at end of the $1980 \mathrm{~s}$, but were negatively affected by external shocks over the last four years. Ethiopia's external debt burden remains high due to exogenous shocks particularly significantly reduced export prices, exchange rate changes, and lower interest rate. The Government has recently started addressing some of the key obstacles to an improved investment climate, including removing regulatory and operational impediments to exports. The Government has also making new efforts to develop exports in non-traditional sectors, in particular in horticulture, garment, textiles, hides and skins, and tourism. 
Despite these domestic developments, Ethiopia continues to face problems of global market access. The EBA (EU) and AGOA (USA) are positive developments and requires capacity building to fully utilize the opportunity. However, according to DTIS, Ethiopia's export bundle is generally subject to higher tariffs in both developing and developed countries. In a sample of 114 countries, 87 countries impose a higher tariff on products exported by Ethiopia than on products on exports by other countries in the sample. On average, across the whole spectrum of countries the tariff imposed on products exported by Ethiopia is 25 percent higher. Non-tariff barriers (WTB) also represent a major problem for Ethiopian exports. Nearly 90 percent of export products are subject to some kind of NTB. Thus, tariffs and NTB. and NTB externally act as a serious barriers to export growth and diversification efforts of Ethiopian -ultimately undermining the efforts for rapid and sustained economic growth and poverty reduction.

The global economy has continued to take its toll through commodity price decline (coffee) with major impact on the BoP and households livelihoods. The international community is visibly indifferent to this plight of poor countries like Ethiopia. It is worth recalling what president Chirac of France has said regarding this problem.

"When it is said that the World's poverty is in rural areas, people sometimes forget to specify that this is in large part due to the volatility of primary product prices and their long-term decline...

"There is on the question of commodities a sort of conspiracy of silence. The solutions are not simple... But nothing justifies the present indifference".

President Jacques Chirac of

France, 21 February 2003

Ethiopia's per capita ODA is half of that of Sub-Saharan average, which is not commensurate with the level of and severity of poverty. The quantity and quality of external aid is important to support the implementation of SDPRP. Government and donors have endorsed the harmonization agenda. The goals of the harmonization's work in Ethiopia seek to increase absorptive capacity for aid while addressing factors that constrain disbursements from existing commitments (high transaction costs-diverse procedures and systems). Also donors are expected to provide sufficient resources in a predictable and sustainable manner. The Government is committed to undertaking the necessary reforms to enable donors to use national systems that are on going through its expenditure management and control reform program. The challenge now is to move forward the work of the Harmonization Task Force with the sense of urgency the situation demands.

Another factor that poses serious challenge for Ethiopia's government for rapid economic growth and poverty reduction is debt sustainability as discussed earlier since the Decision Point for HIPC, Ethiopia's NPV debt-effort ratio has deteriorated markedly as a result of external shocks which are beyond Ethiopia's control. This development has even affected Ethiopia's full access to IDA's lending. This calls for greater flexibility to balance Ethiopia's huge demand for future rapid growth and poverty reduction with the issue of debt sustainability. 


\section{References}

Alemseged Assefa, Vice governor of National bank of Ethiopia, May 2003, Brief note on Impact of coffee crisis on the Ethiopian Economy and coffee farmers, An address prepared for the meeting with honorable members of the British Parliament, London, U.K.

Ethiopian Women Development Fund, July 2003, Women Development Initiative Project (WDIP) 1995 EFY Annual Report.

Ethiopia- Diagnostic Trade Integration study, August 29,2003(revised)

Federal Democratic Republic of Ethiopia, August 2002, Industry Development Strategy.

International Monetary Fund, March 2003, Ethiopia: Fiscal Decentralization: the Way Forward.

International Monetary Fund, December 2002, Ethiopia: Improving Fiscal Reporting Under Decentralization.

International Monetary Fund, 2003, PSIA in Ethiopia: An analysis of the incidence of the VAT and Public Expenditure on Education and Health.

International Monetary Fund, July 2003, Fourth Review and Third Annual Program under the Three- year Arrangement under PRGF and Request for Extension of Arrangements and for Additional Interim Assistance under enhanced HIPC Initiative.

MOFED, July 2002, Ethiopia: Sustainable Development and Poverty Reduction Strategy Programme.

MOFED, 2003, Ethiopia: Post HIPC Debt Strategy and New Financing Workshop Report, Human development 3, country department 6: Ethiopia and Sudan, Africa region.

MOFED, September 2003, Ethiopia: External shocks, debt sustainability and Millennium Development Goals (discussion note), joint World Bank-IMF workshop on debt sustainability in low-income countries, Washington D.C.

MOFED and UN country team, 2003, Millennium Development Goals: Challenges and Prospects for Ethiopia.

MOFED, Economic Policy and Planning Department, July 2003, ERSC and ESAC implementation completion report.

MOFED, October 2003,Strengthening data collection, analysis and dissemination on poverty monitoring and the Millennium Development Goals, Proposal to the Development Assistance Group.

New coalition for food security in Ethiopia technical group, October 2003, Food Security Program (revised). 
SC-UK Ethiopia, 2002, Destitution In Northeastern Highlands (Amhara region) - Interim Report.

World Bank, September 2003, Poverty Reduction Strategy Papers: Progress in Implementation and detailed analysis of progress in implementation.

World Bank, 2003, Ethiopia: Risks and Vulnerability Assessment.

World Bank, March 2003, Memorandum of the president of the international development association to the executive directors on a country assistance strategy for the Federal Democratic Republic of Ethiopia, Report No. 25591-ET, Country department 6, Africa region.

World Bank, July 2003, Ethiopia: Public Expenditure Review Volume I "Public Spending in the Social Sectors - The Emerging Challenge", AFTP2, Africa region 
Annexes 
Ethiopia: Framework of Goals, Actions, Outputs and Targets for SDPRP Policy Matrix (2002/03-2004/05)

Ministry of Finance and Economic Development

(MOFED) 


\section{Introduction}

This document describes the goals, outcomes, outputs, inputs/policy actions during the period 2002/032004/05 as contained in the Sustainable Development and Poverty Reduction Program (SDPRP). For the purpose of PRSC the SDPRP is classified in to four thematic groups. They are: Enhanced Rapid Economic Growth, Improving Human Development, Democratization and Governance, and Improving Public Sector institutional Performance. The Matrix here under describes the goals, outcomes, outputs, and inputs/policy actions and targets during the outer two years of the SDPRP period under each thematic area. Besides it shows progress to date i.e., actions undertaken and targets achieved during the first year of SDPRP implementation (2002/03). 


\section{SDPRP Policy Matrix}

The four thematic areas and the fourteen (14) sub-thematic areas to focus efforts are presented as follows:

\begin{tabular}{|c|c|}
\hline Theme & Identified Sub-thematic Area \\
\hline \multirow[t]{4}{*}{ I. Enhanced Rapid Economic Growth } & 1. Private Sector Development. \\
\hline & 2. Rural Development \\
\hline & 3. Vulnerability \\
\hline & 4. Roads \\
\hline \multirow[t]{4}{*}{ II. Improved Human Development } & 1. Education \\
\hline & 2. Health \\
\hline & 3. HIVIAIDS \\
\hline & 4. Water \\
\hline \multirow[t]{3}{*}{ III. Democratization \& Governance } & 1. Decentralization \\
\hline & 2. Justice System Reform \\
\hline & 3. Urban Management \\
\hline \multirow{3}{*}{$\begin{array}{l}\text { IV. Improved Public Sector Institutional } \\
\text { Performance }\end{array}$} & 1. Civil Service Reform \\
\hline & 2. Tax Reform \\
\hline & 3. ICT \\
\hline
\end{tabular}




\section{Ethiopia: Results Diagram for SDPRP Policy Matrix}

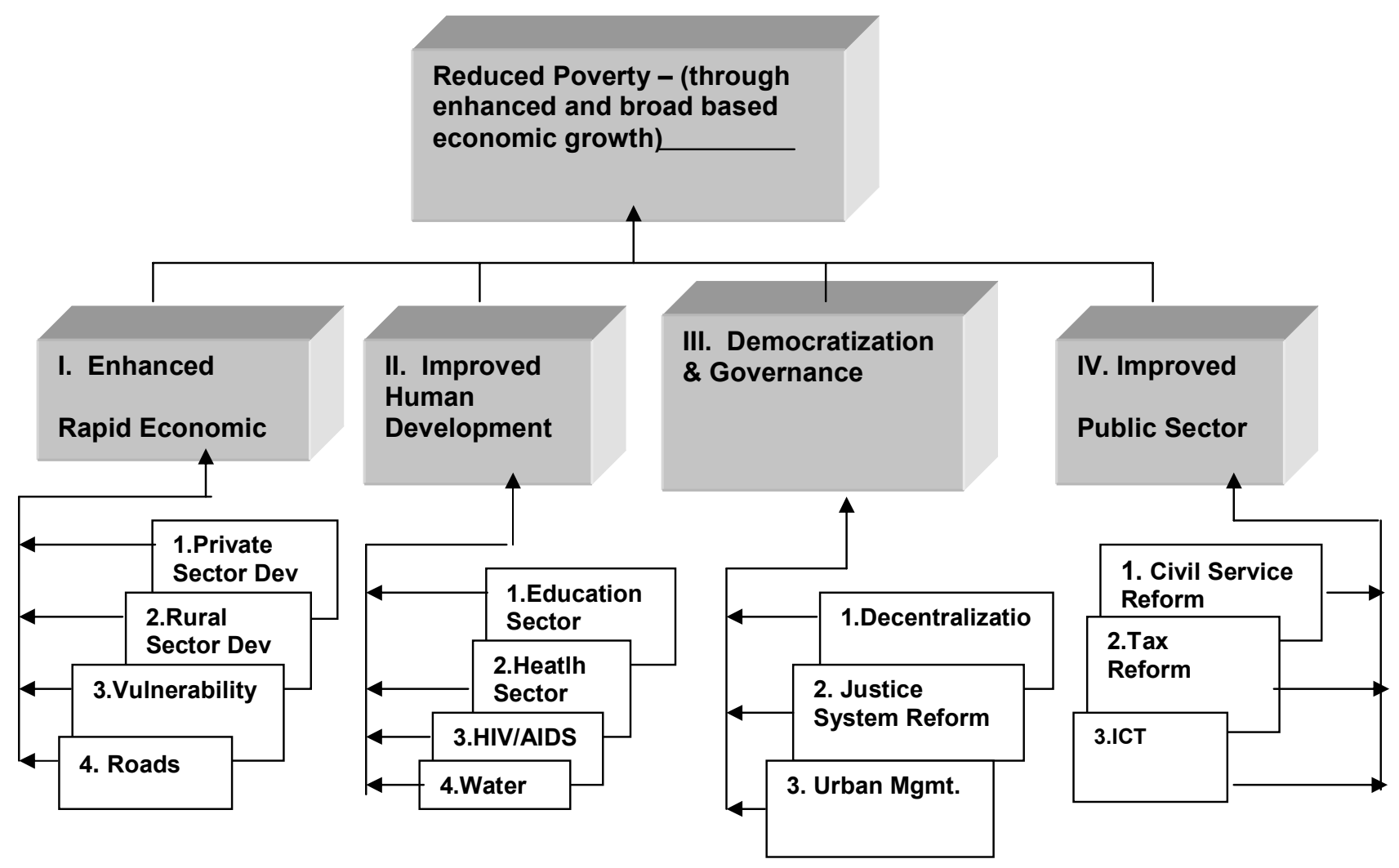




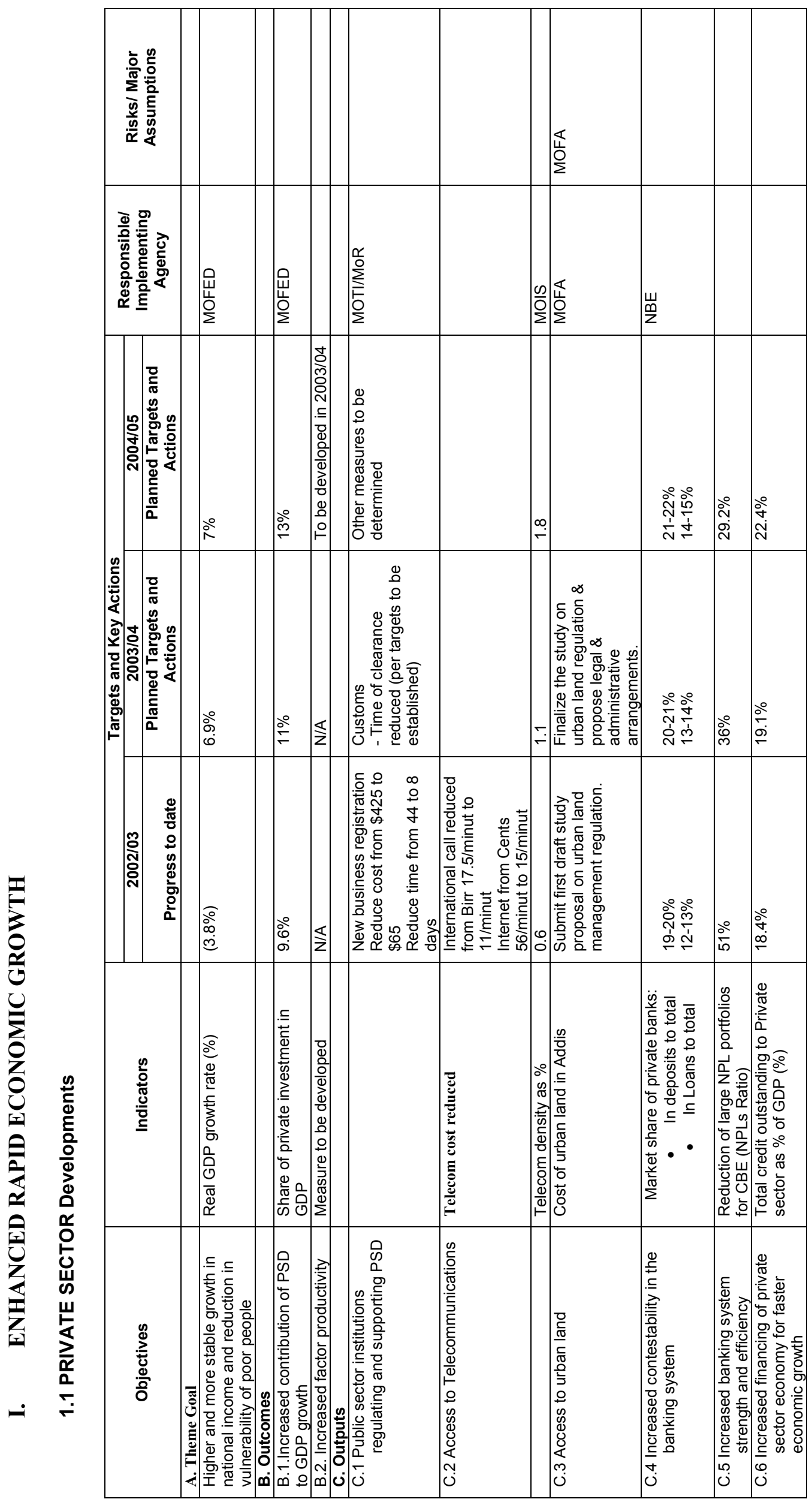

$\bar{N}$

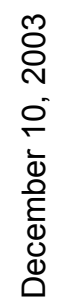




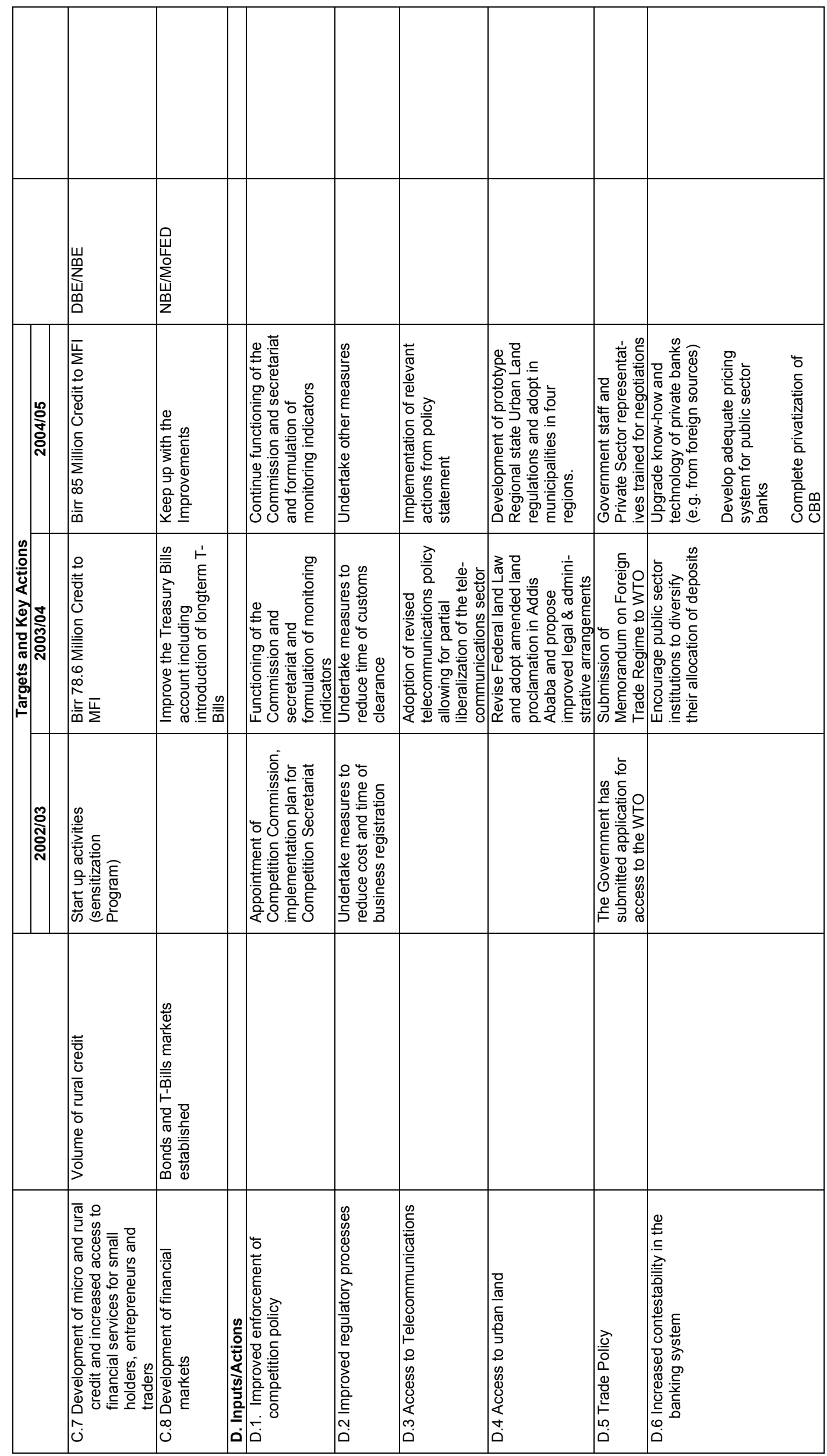

ลั

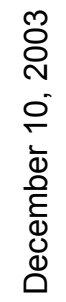




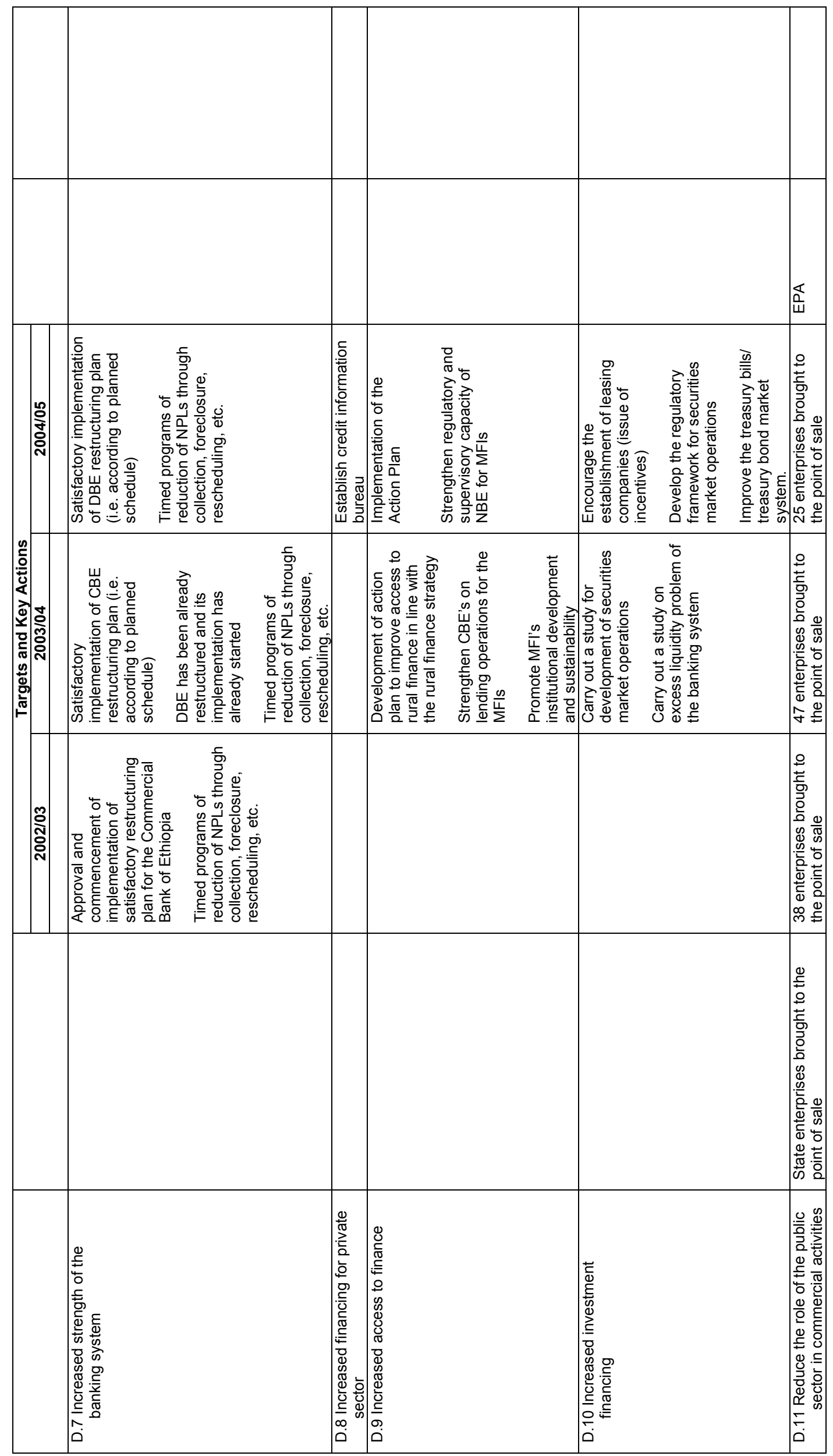

$\stackrel{?}{\sim}$

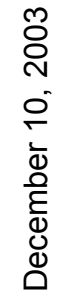




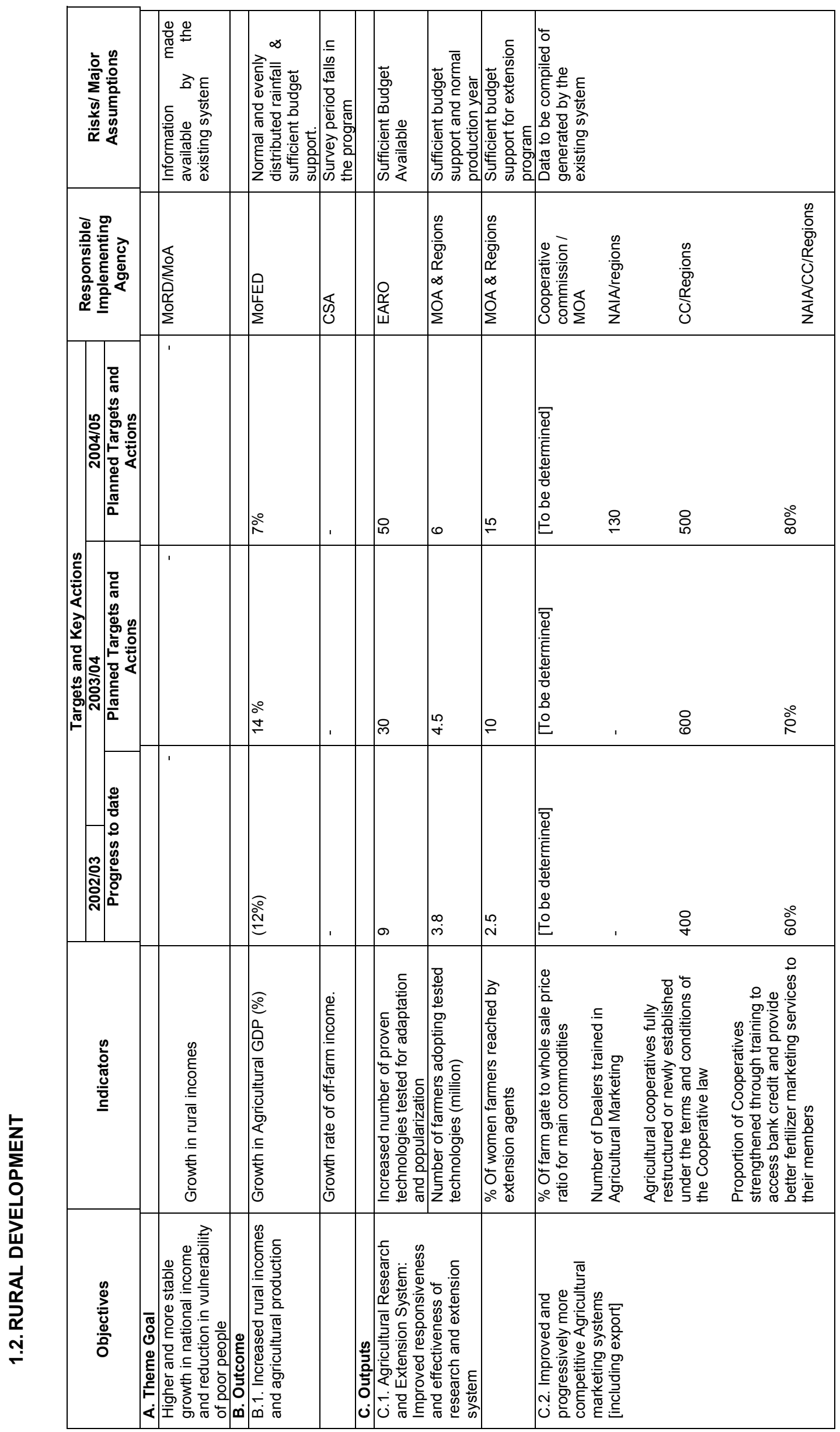

$\stackrel{ \pm}{N}$

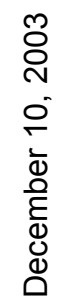




\begin{tabular}{|c|c|c|c|c|c|c|c|}
\hline 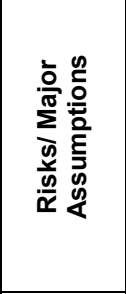 & 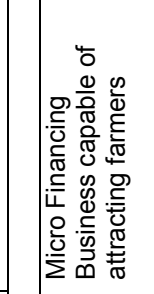 & 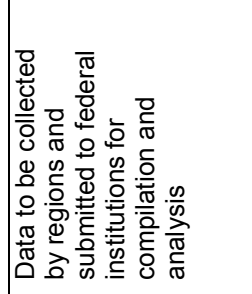 & 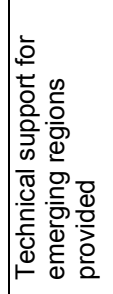 & 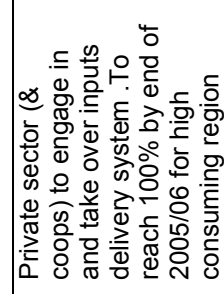 & 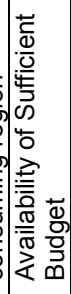 & & 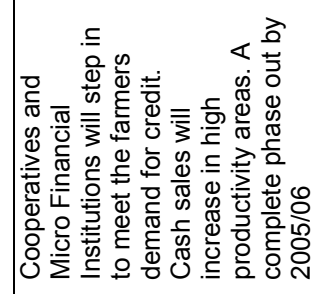 \\
\hline 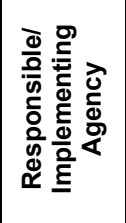 & 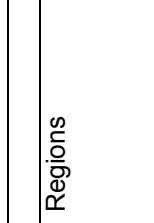 & 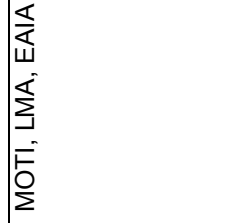 & 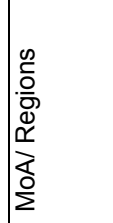 & 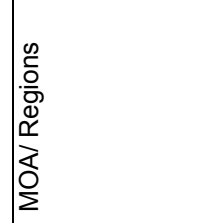 & 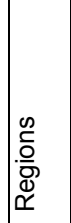 & 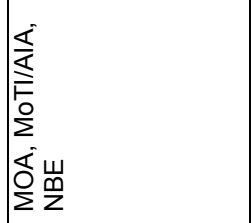 & 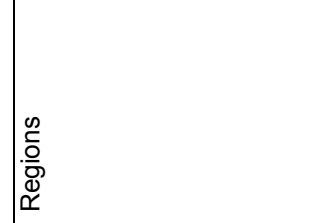 \\
\hline 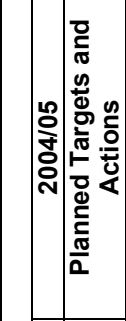 & 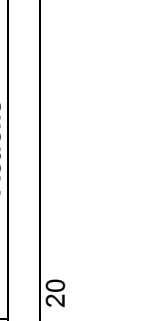 & Q & 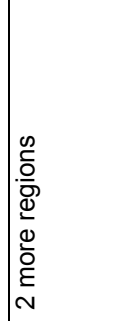 & 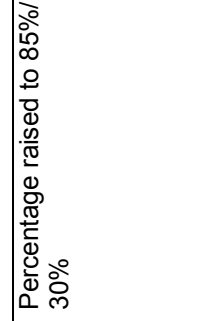 & ষ্ণ & 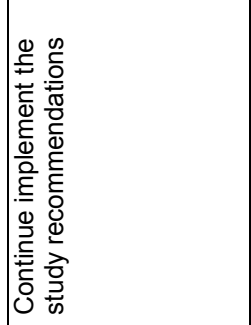 & 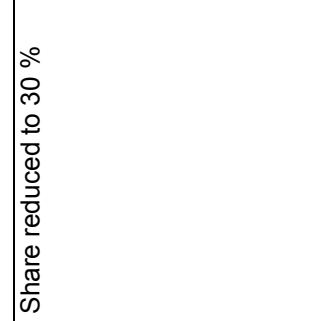 \\
\hline 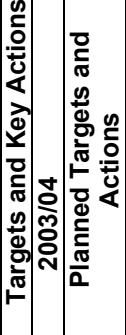 & $\stackrel{\circ}{\circ}$ & $\stackrel{Q}{\stackrel{Q}{\rho}}$ & 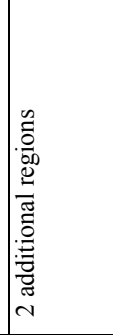 & 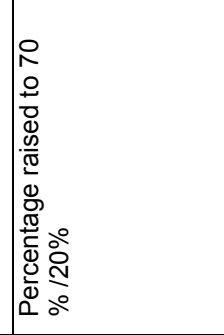 & 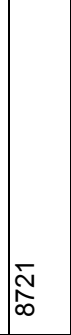 & 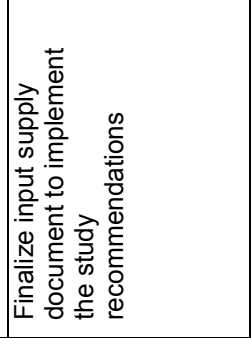 & 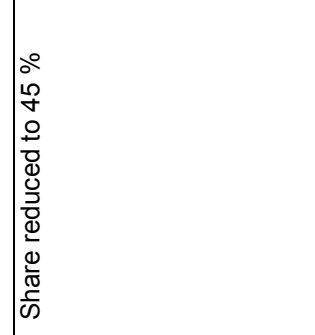 \\
\hline 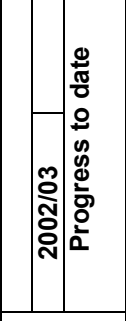 & & 吕 & + & 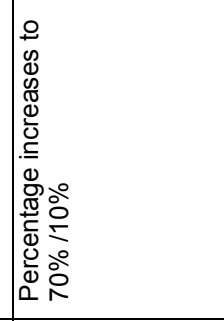 & & 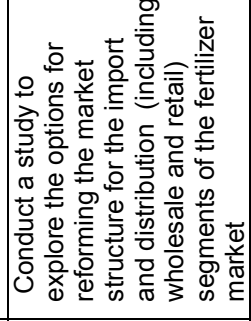 & 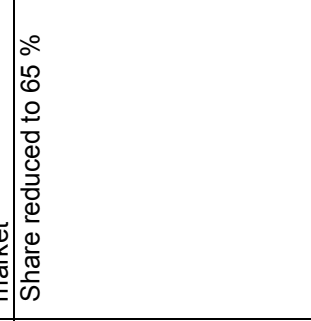 \\
\hline 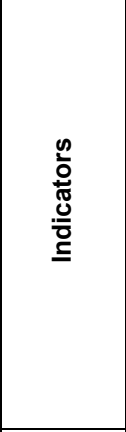 & 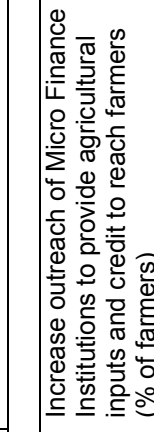 & 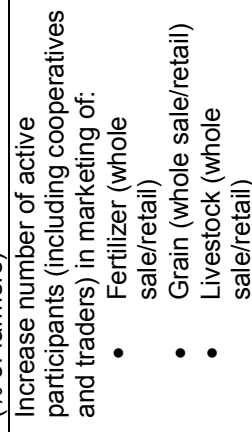 & 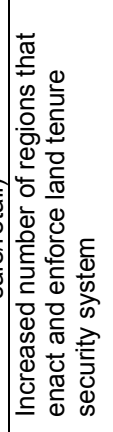 & 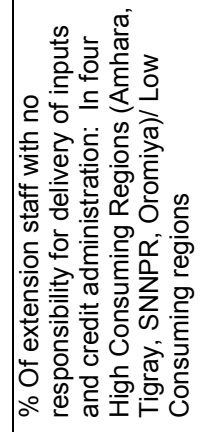 & 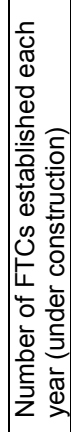 & 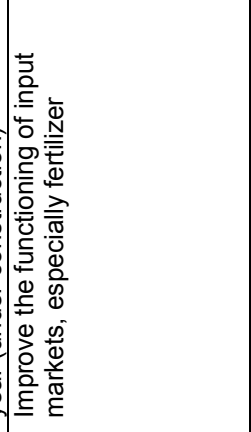 & 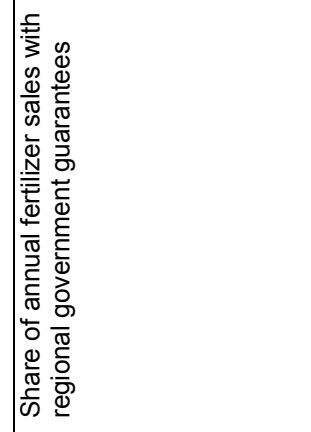 \\
\hline 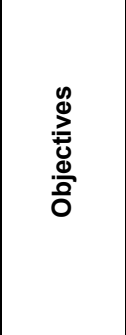 & 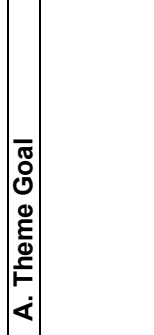 & & 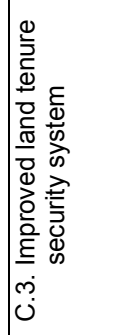 & 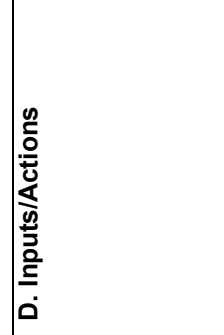 & 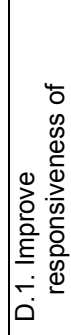 & 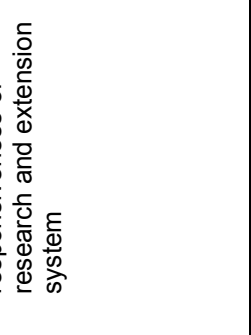 & 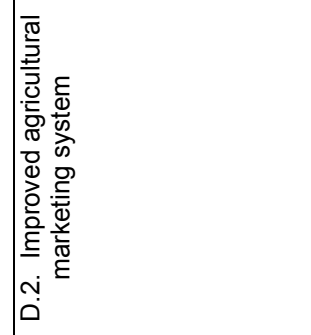 \\
\hline
\end{tabular}

$\stackrel{\stackrel{N}{ }}{ }$

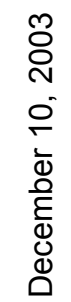




\begin{tabular}{|c|c|c|c|c|}
\hline 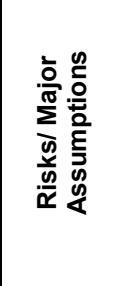 & 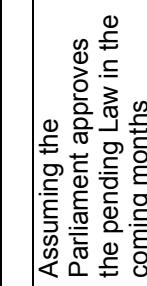 & & & \\
\hline 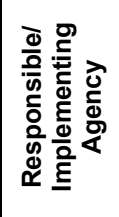 & 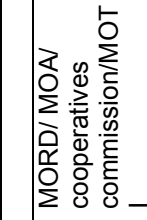 & \multicolumn{2}{|c|}{ 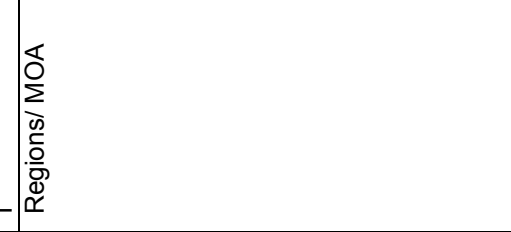 } & \\
\hline 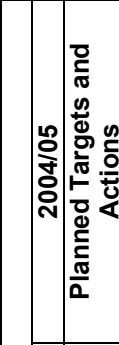 & 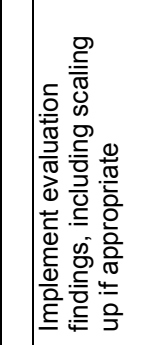 & 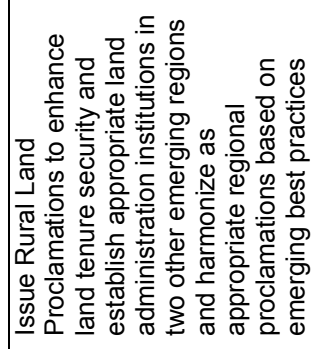 & 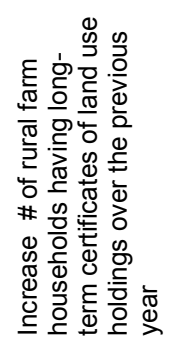 & \\
\hline 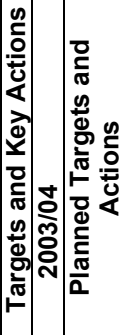 & 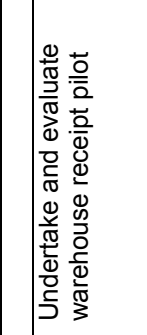 & 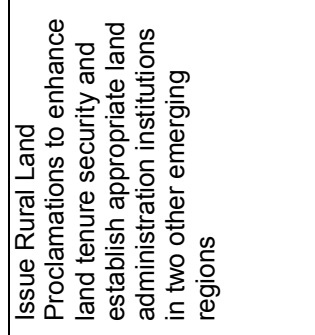 & 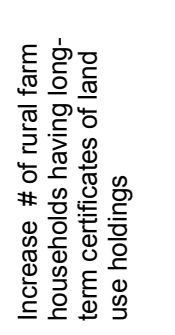 & \\
\hline 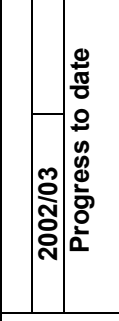 & 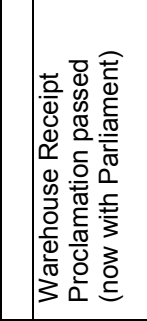 & 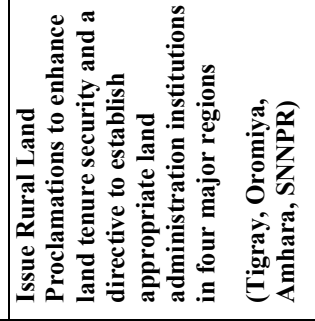 & & \\
\hline 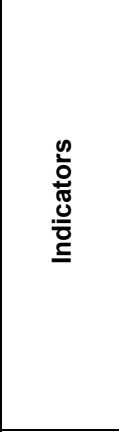 & 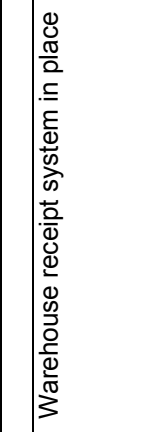 & & & \\
\hline 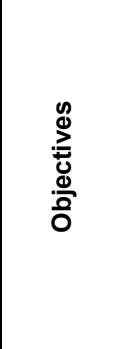 & 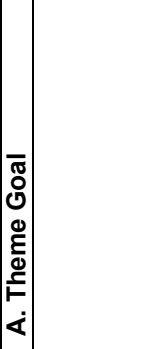 & & & 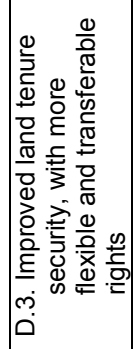 \\
\hline
\end{tabular}




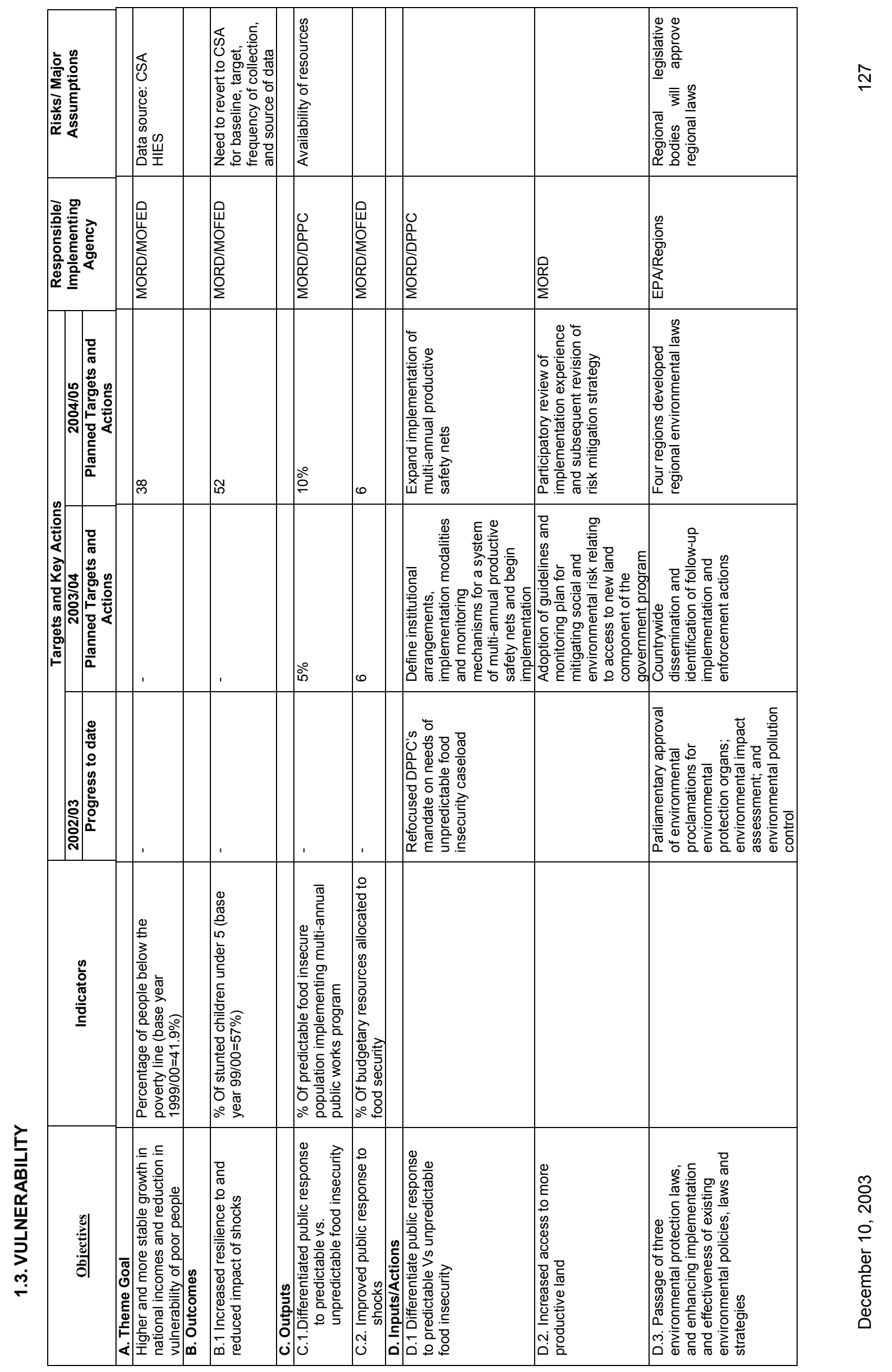




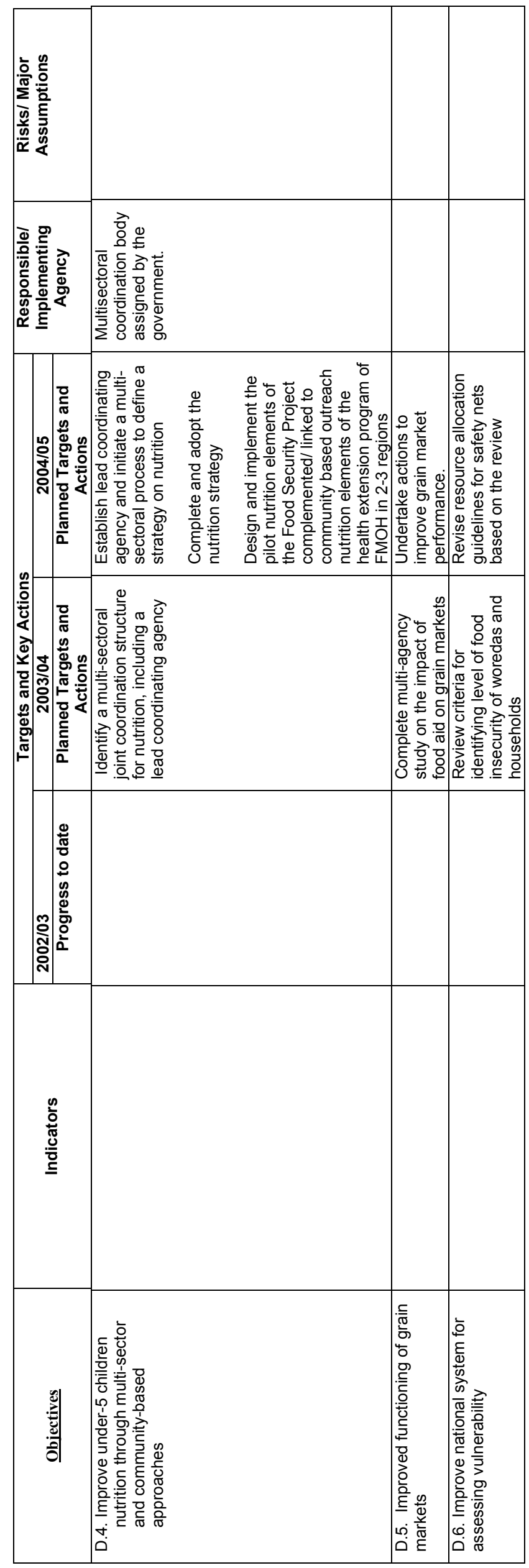

$\stackrel{\infty}{\sim}$

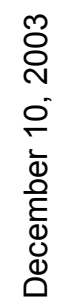




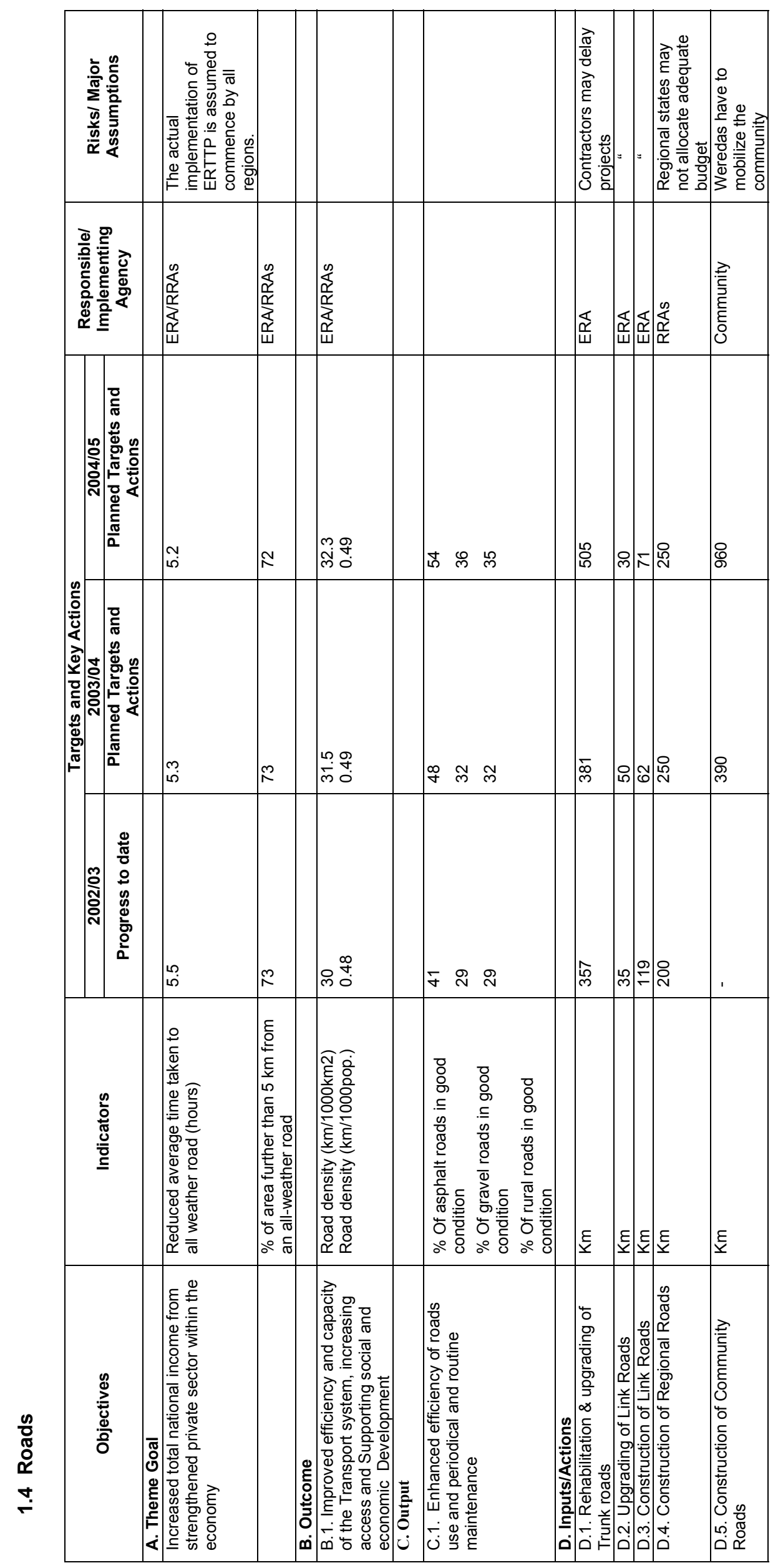

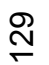




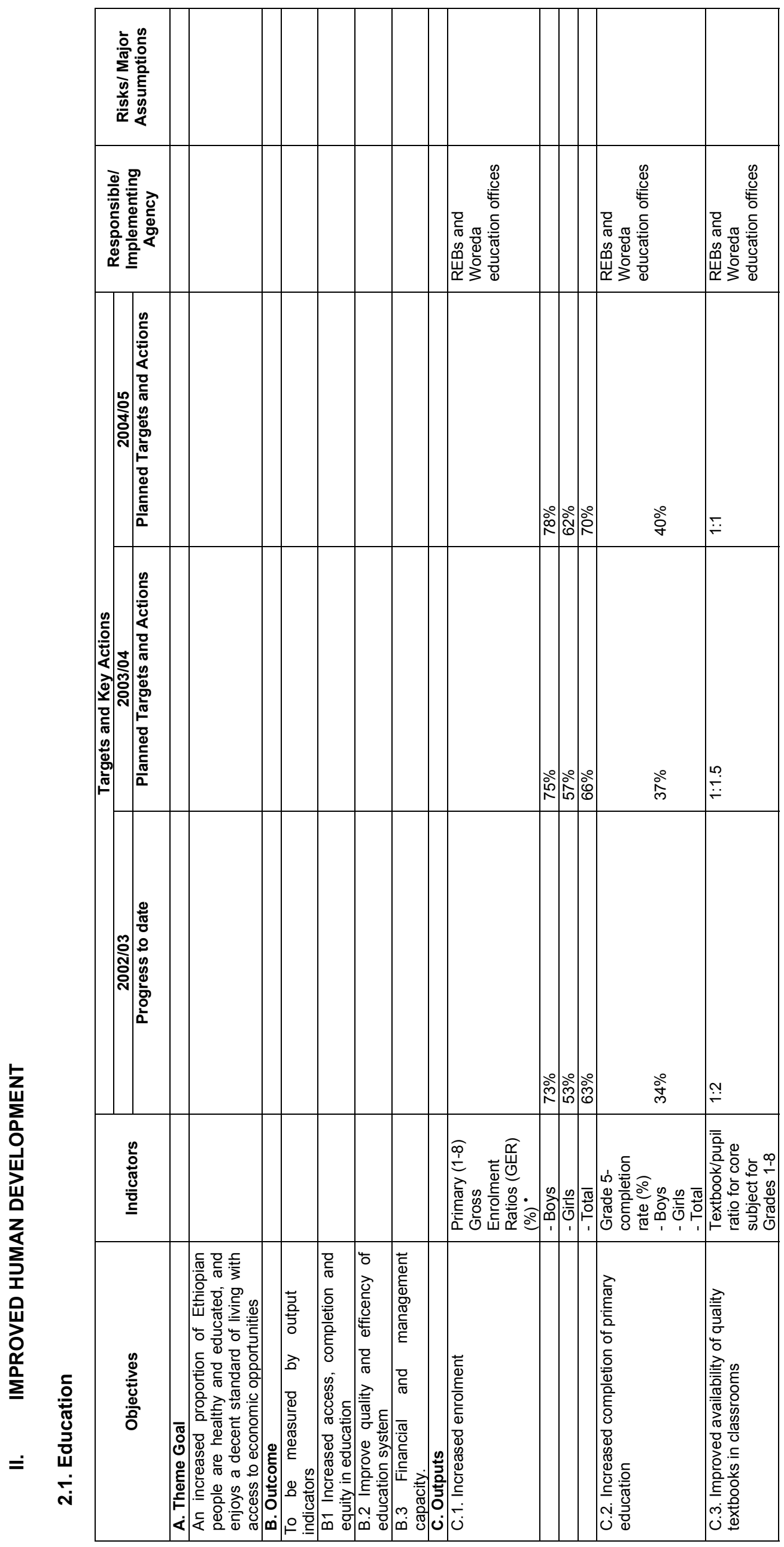

욤 


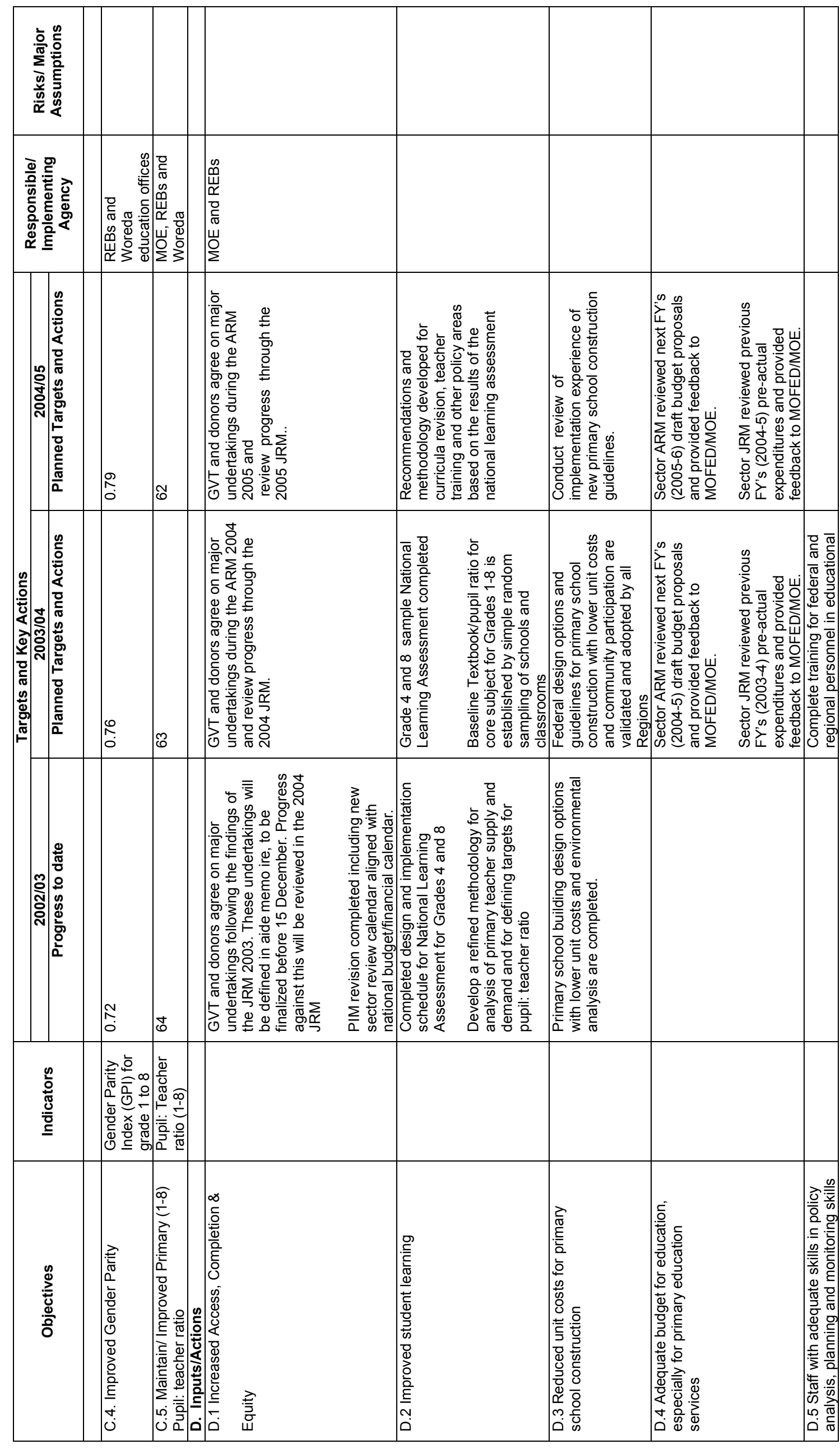



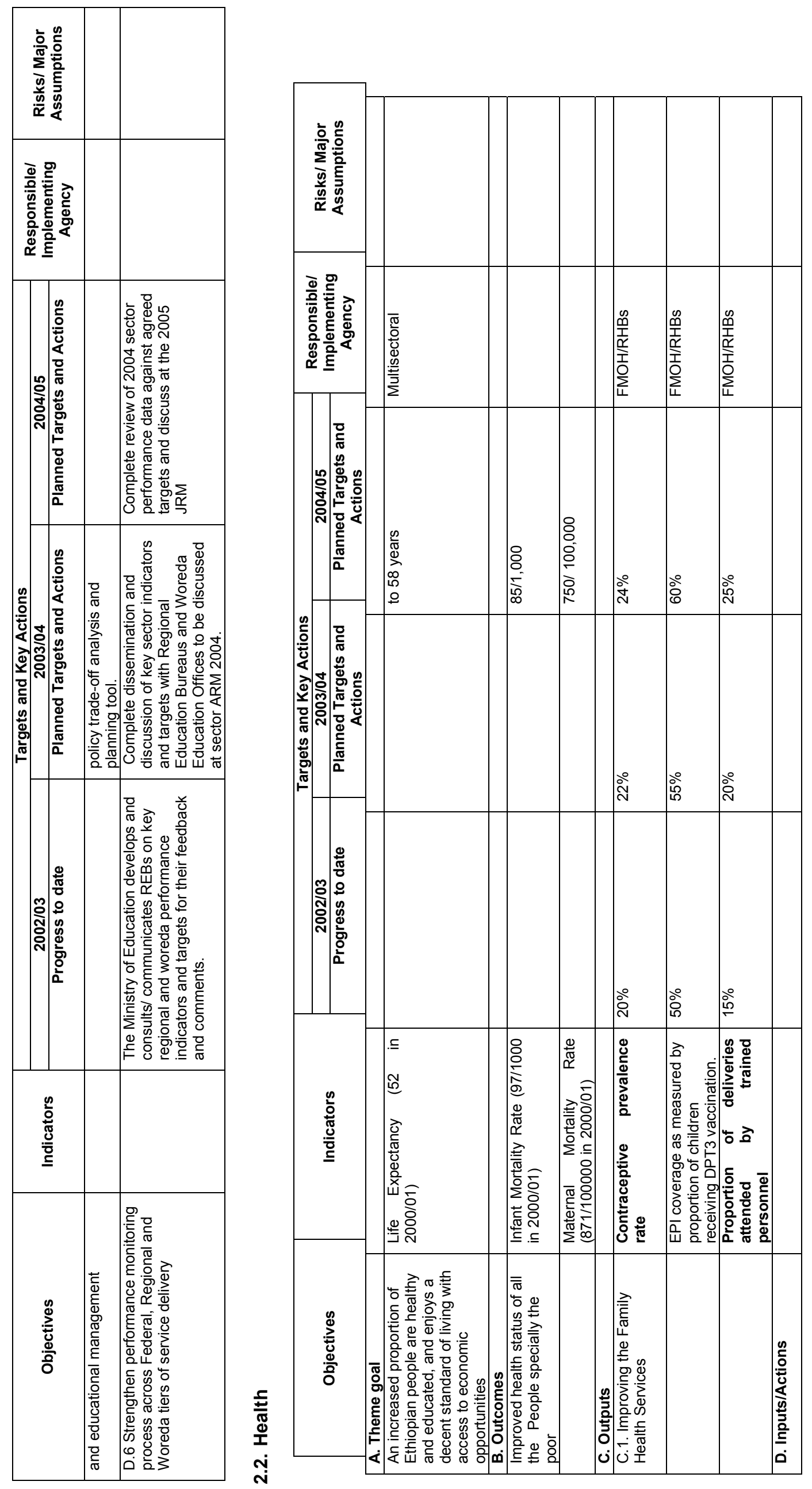

뜸

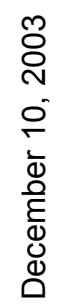




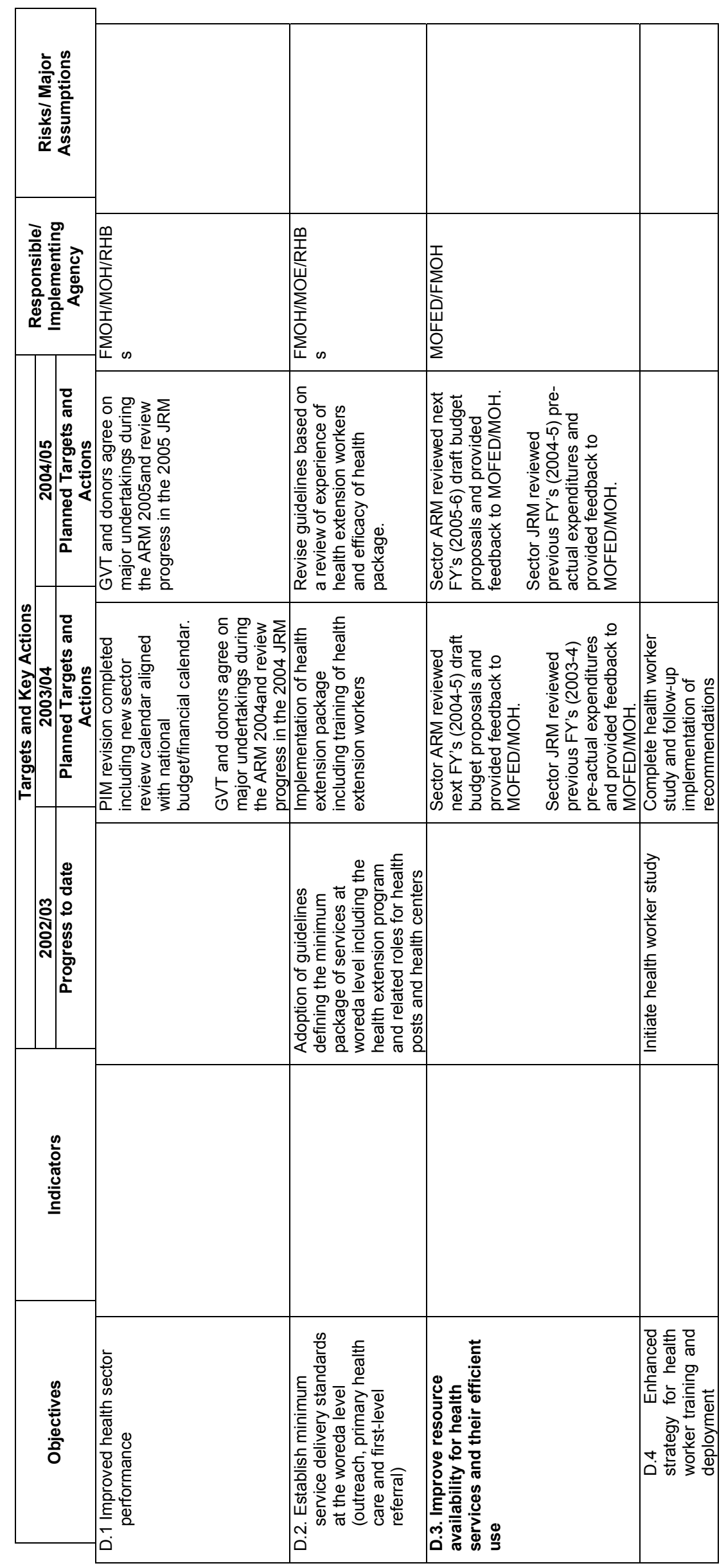

$\stackrel{m}{\stackrel{m}{m}}$

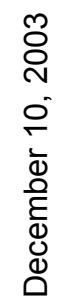




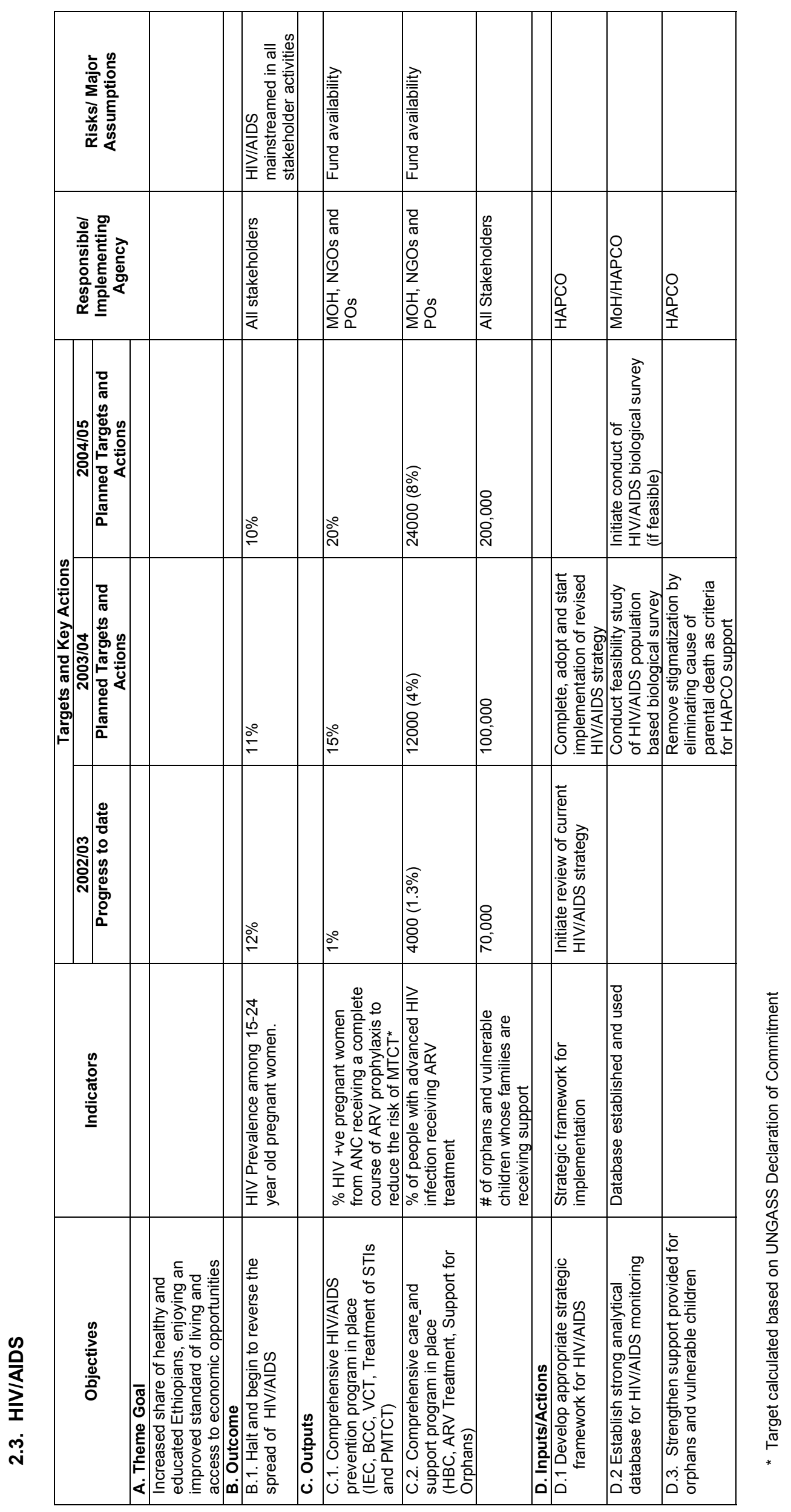

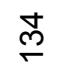

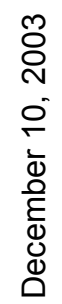




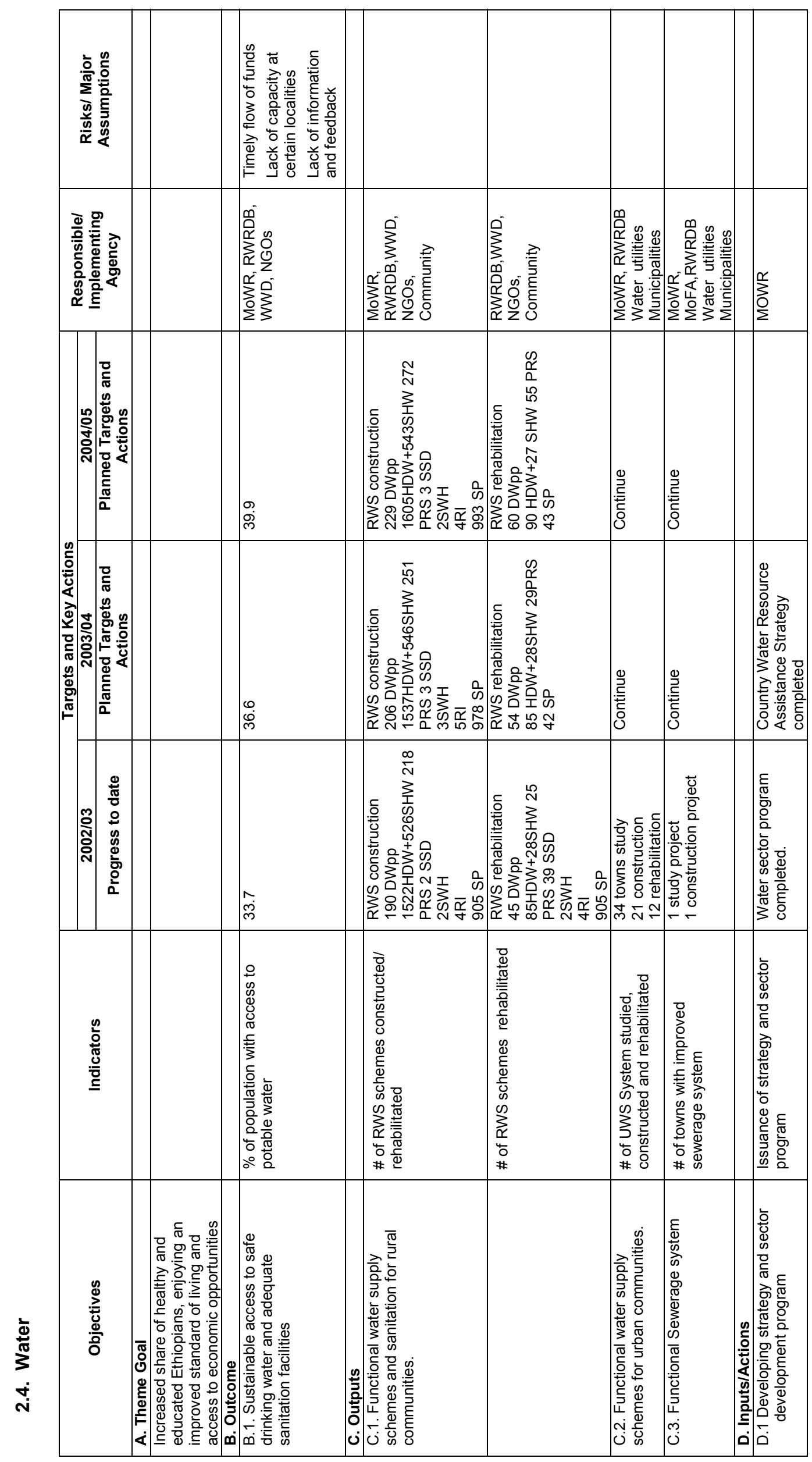

$\stackrel{\infty}{\stackrel{m}{m}}$

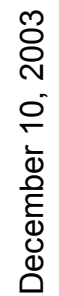




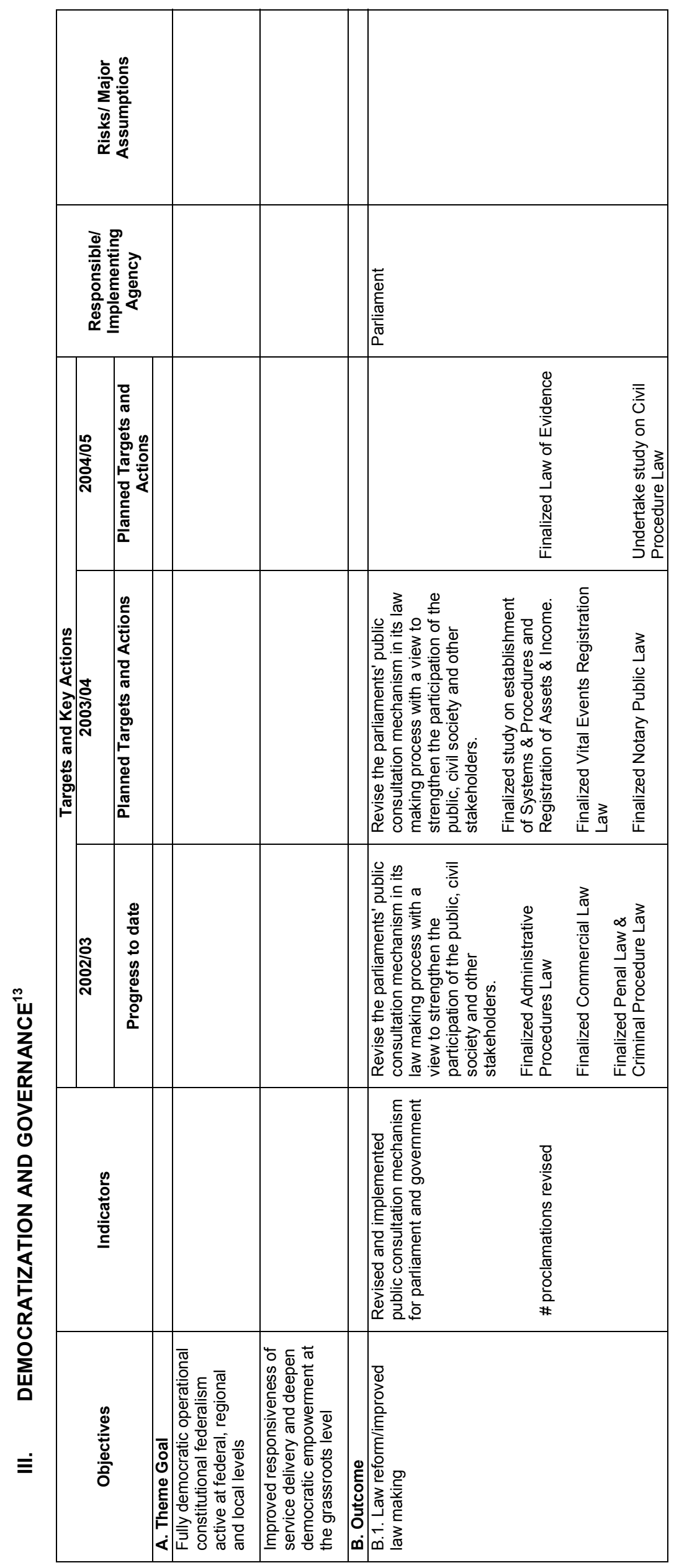

$\stackrel{\circ}{\stackrel{\circ}{c}}$

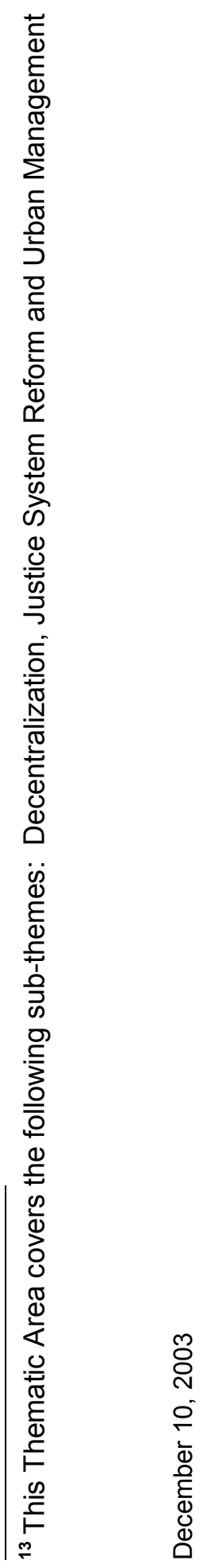




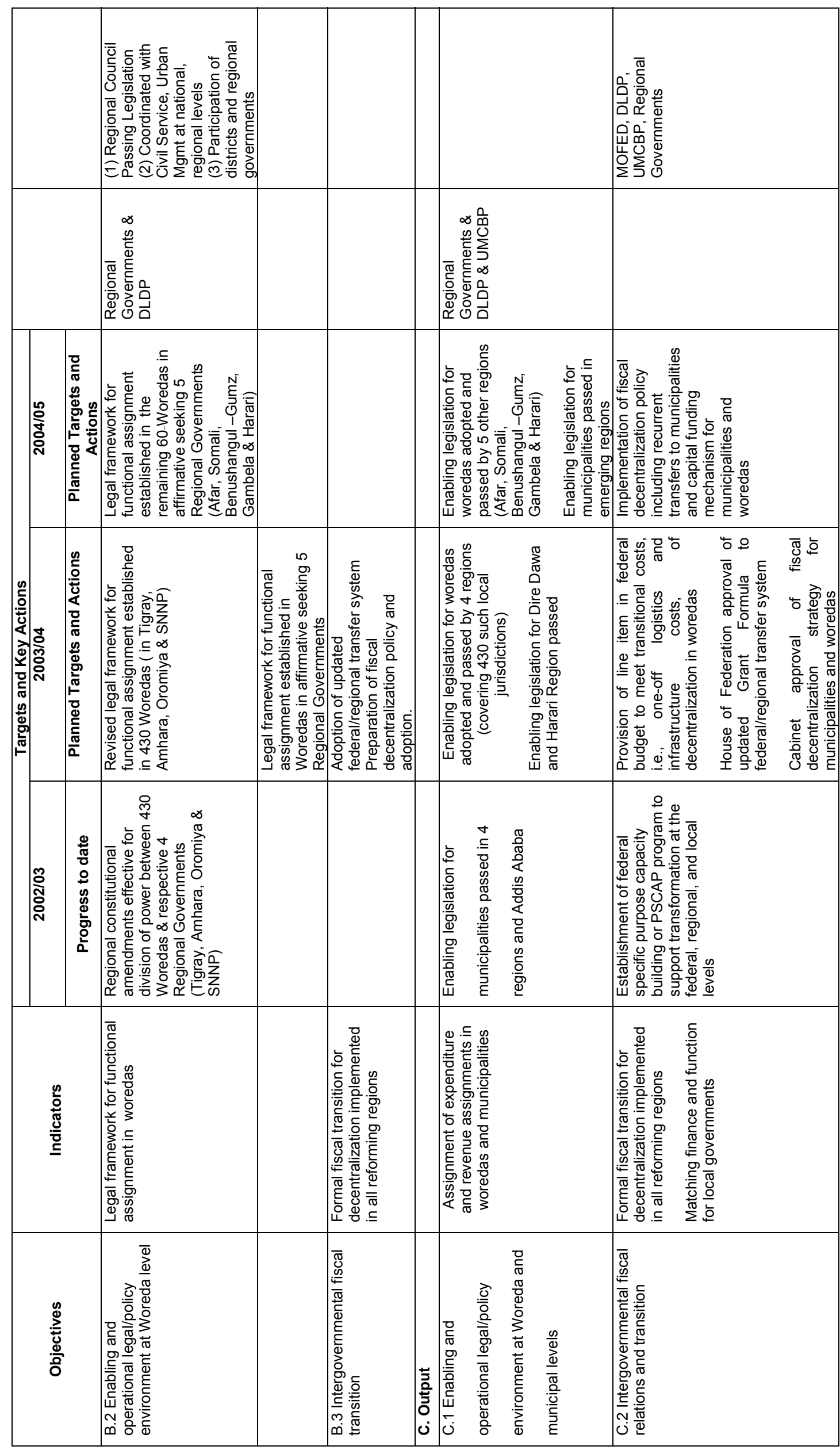

옴 


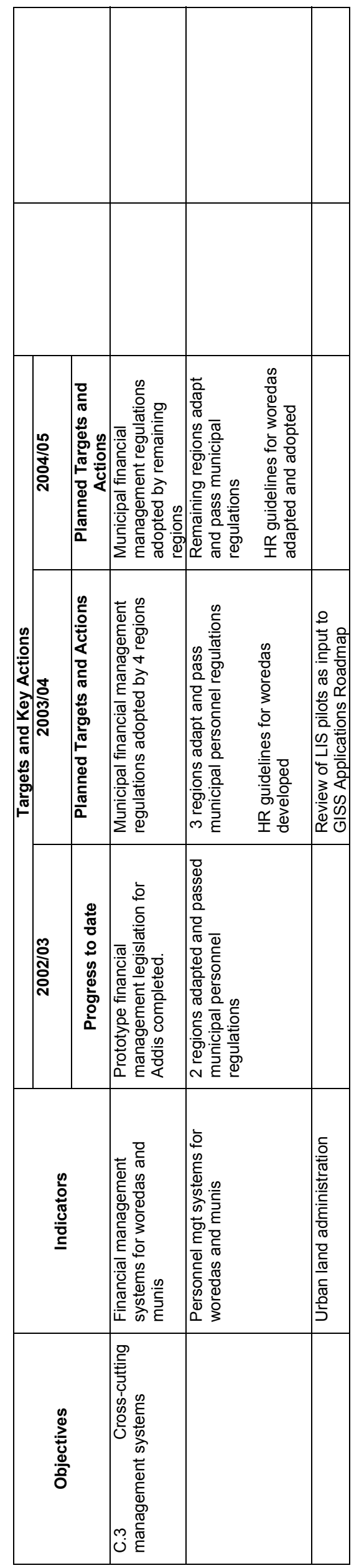




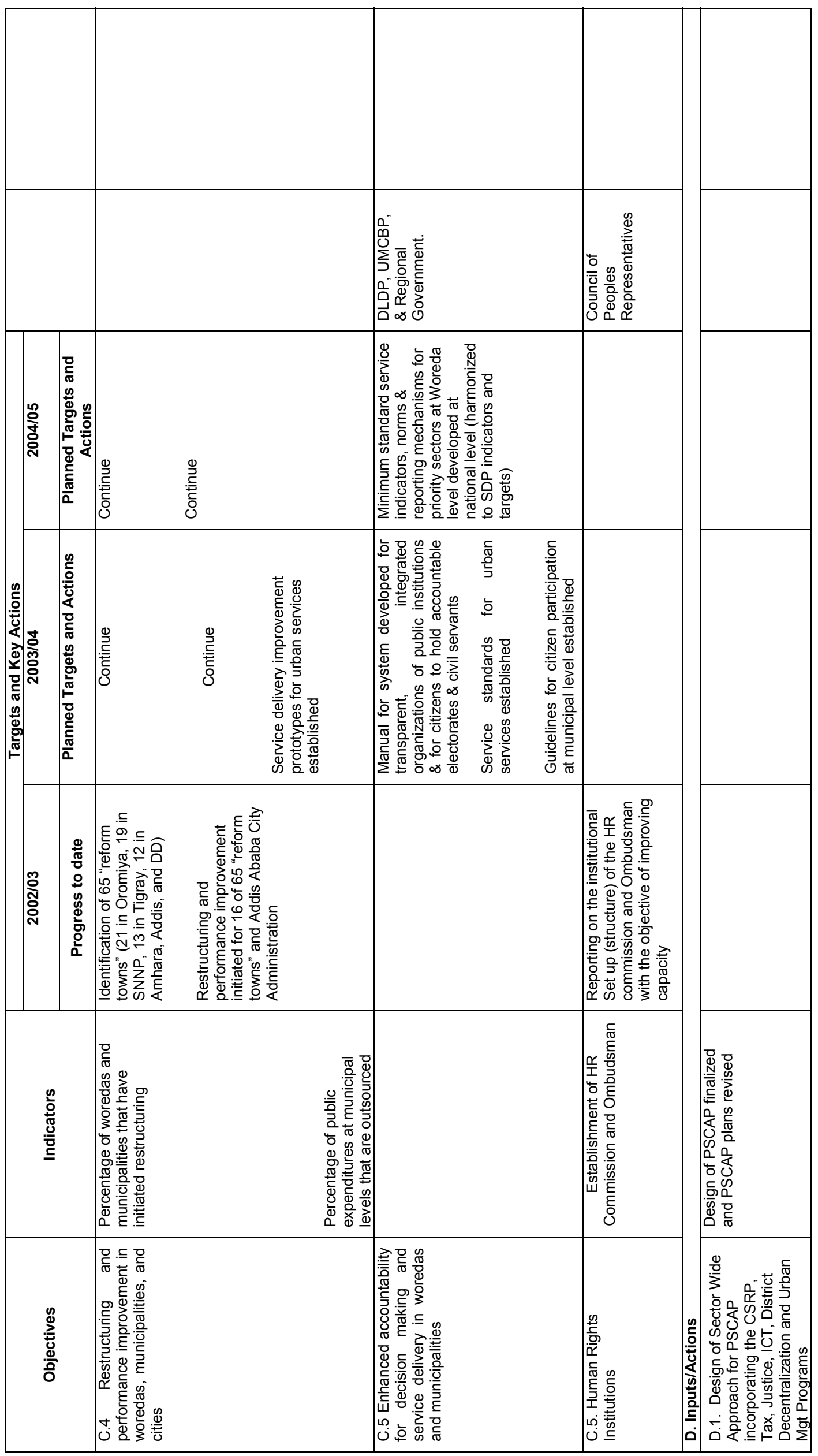

욤

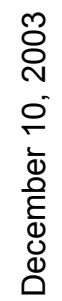




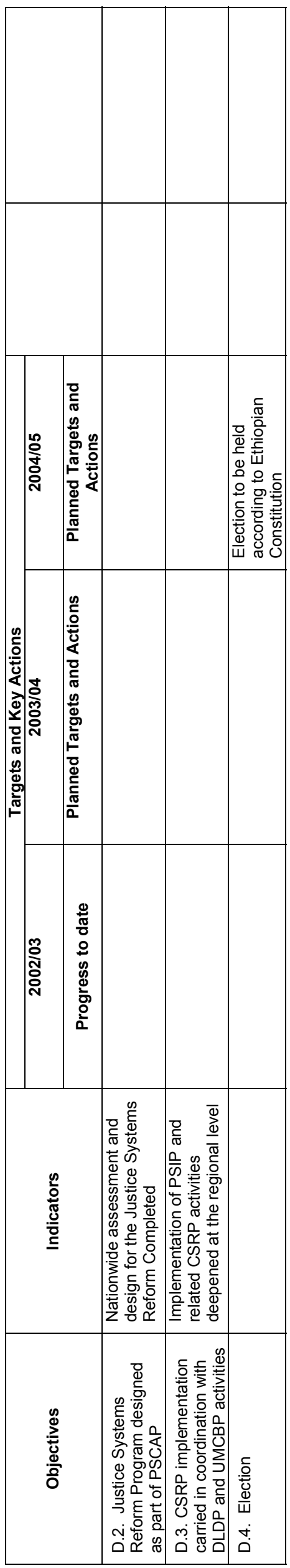

옴

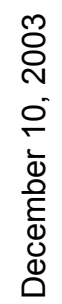




\begin{tabular}{|c|c|c|c|c|c|c|}
\hline & & 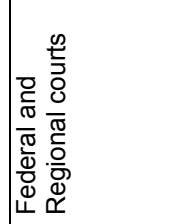 & 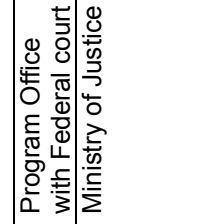 & 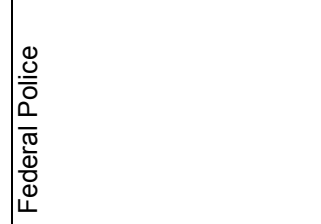 & 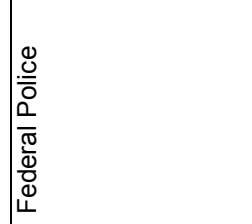 & \\
\hline ڤ̊ & 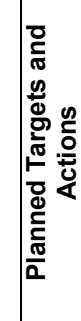 & 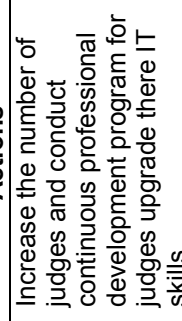 & 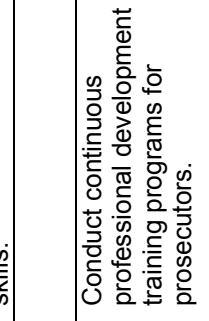 & 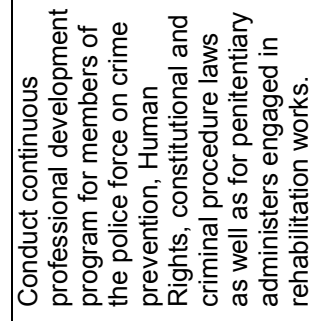 & 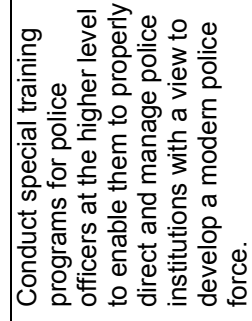 & \\
\hline 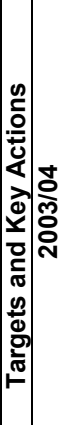 & 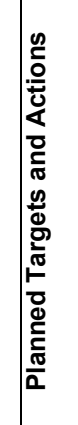 & 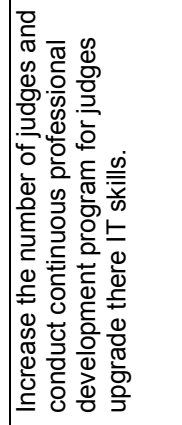 & 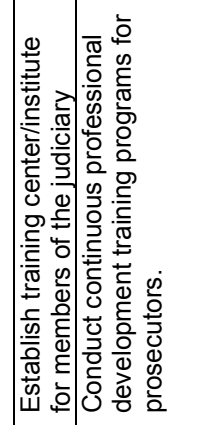 & 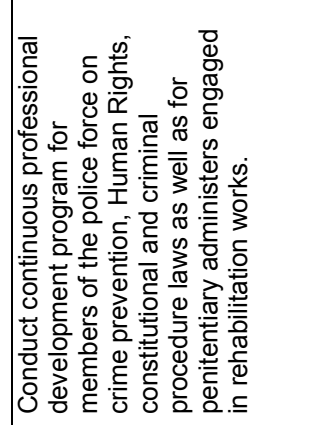 & 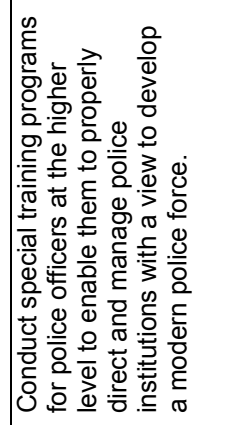 & 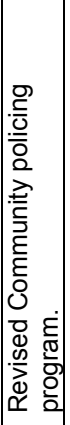 \\
\hline 孞 & 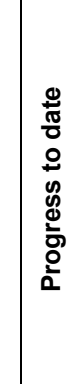 & 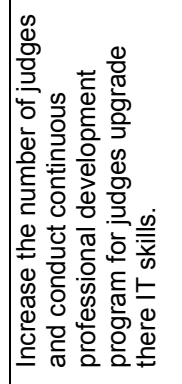 & 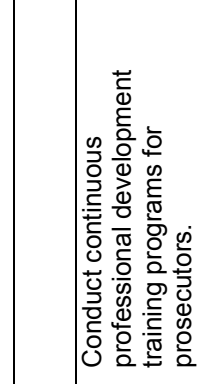 & 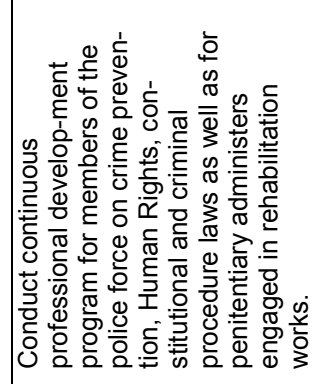 & 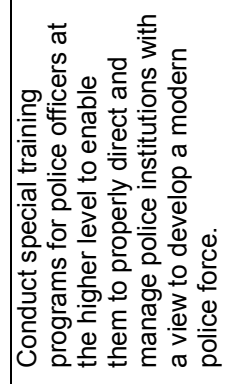 & \\
\hline 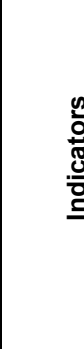 & 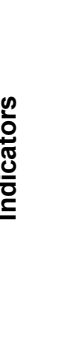 & 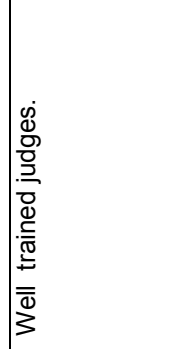 & 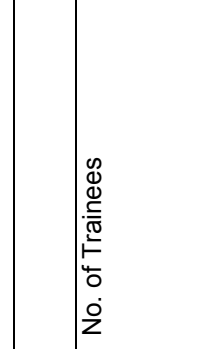 & & & 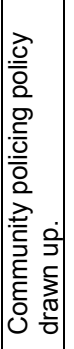 \\
\hline & 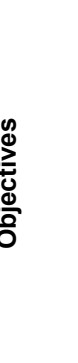 & 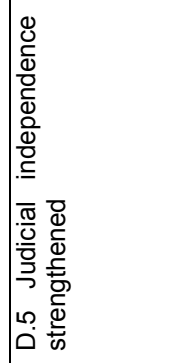 & 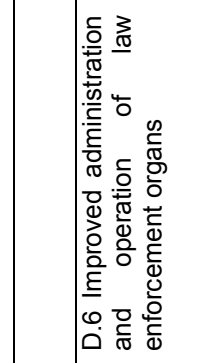 & & & \\
\hline
\end{tabular}

$\underset{\square}{\check{J}}$

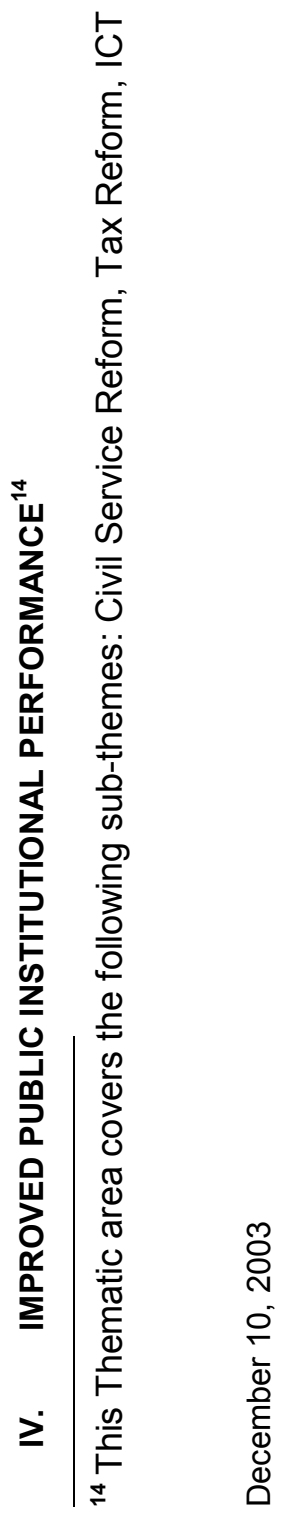




\begin{tabular}{|c|c|c|c|c|c|}
\hline 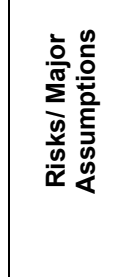 & & 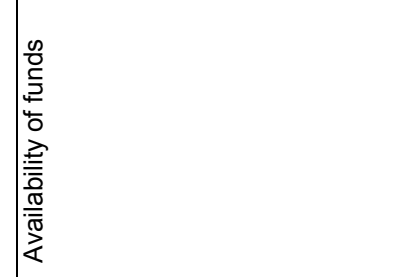 & & & \\
\hline 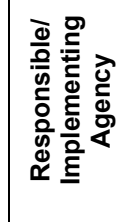 & & 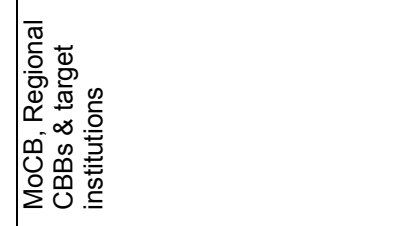 & & & \\
\hline 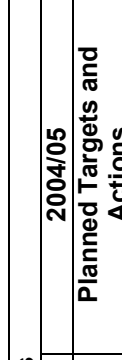 & & 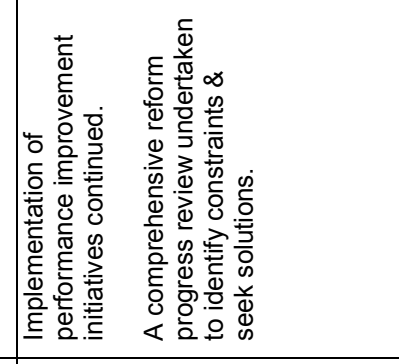 & 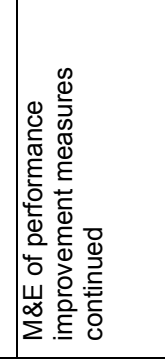 & & \\
\hline 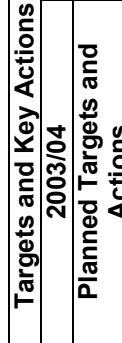 & & 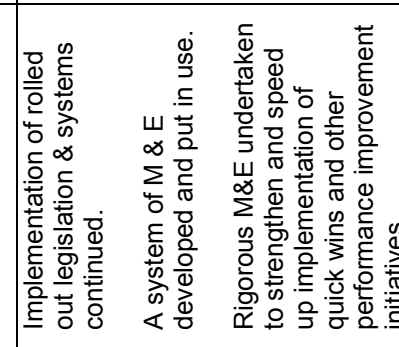 & 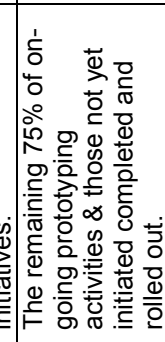 & 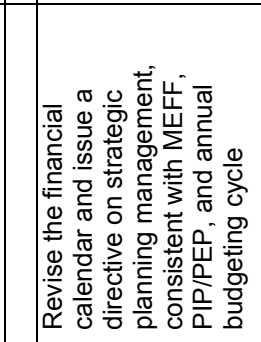 & 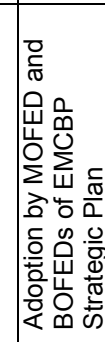 \\
\hline 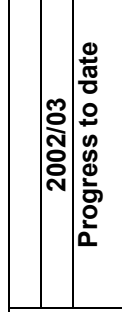 & & 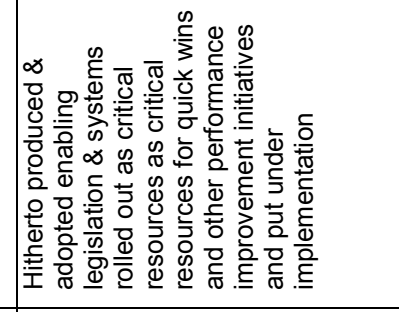 & 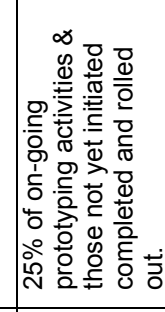 & 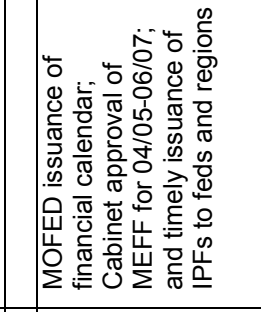 & \\
\hline 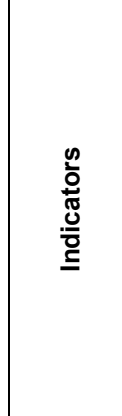 & & 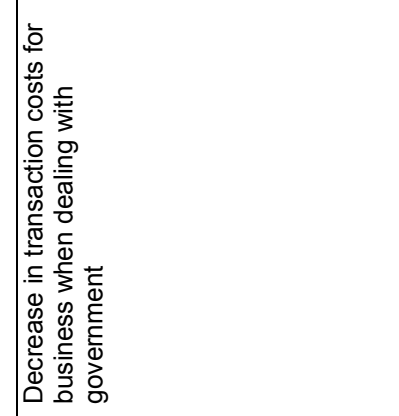 & & & 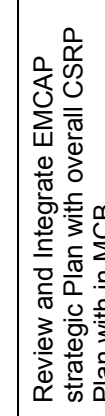 \\
\hline 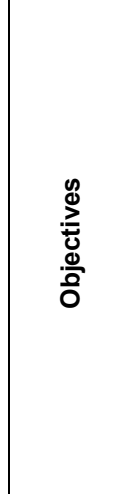 & 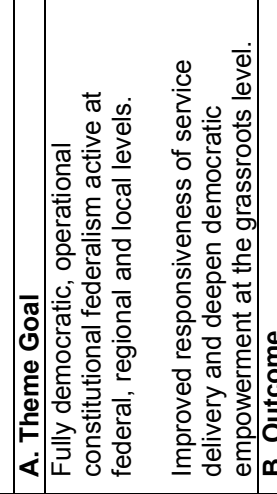 & 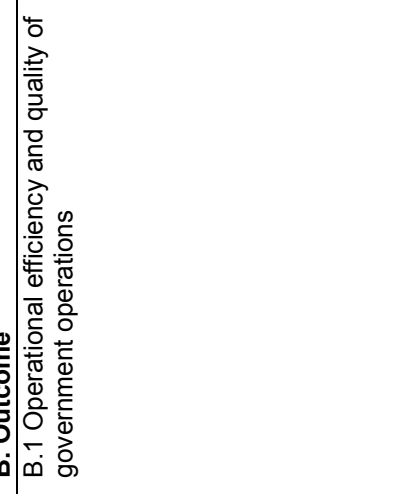 & & 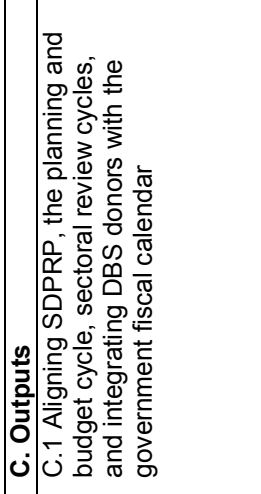 & 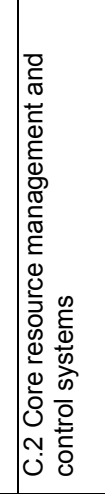 \\
\hline
\end{tabular}

$\stackrel{ }{\leftarrow}$

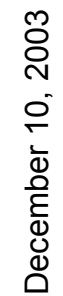




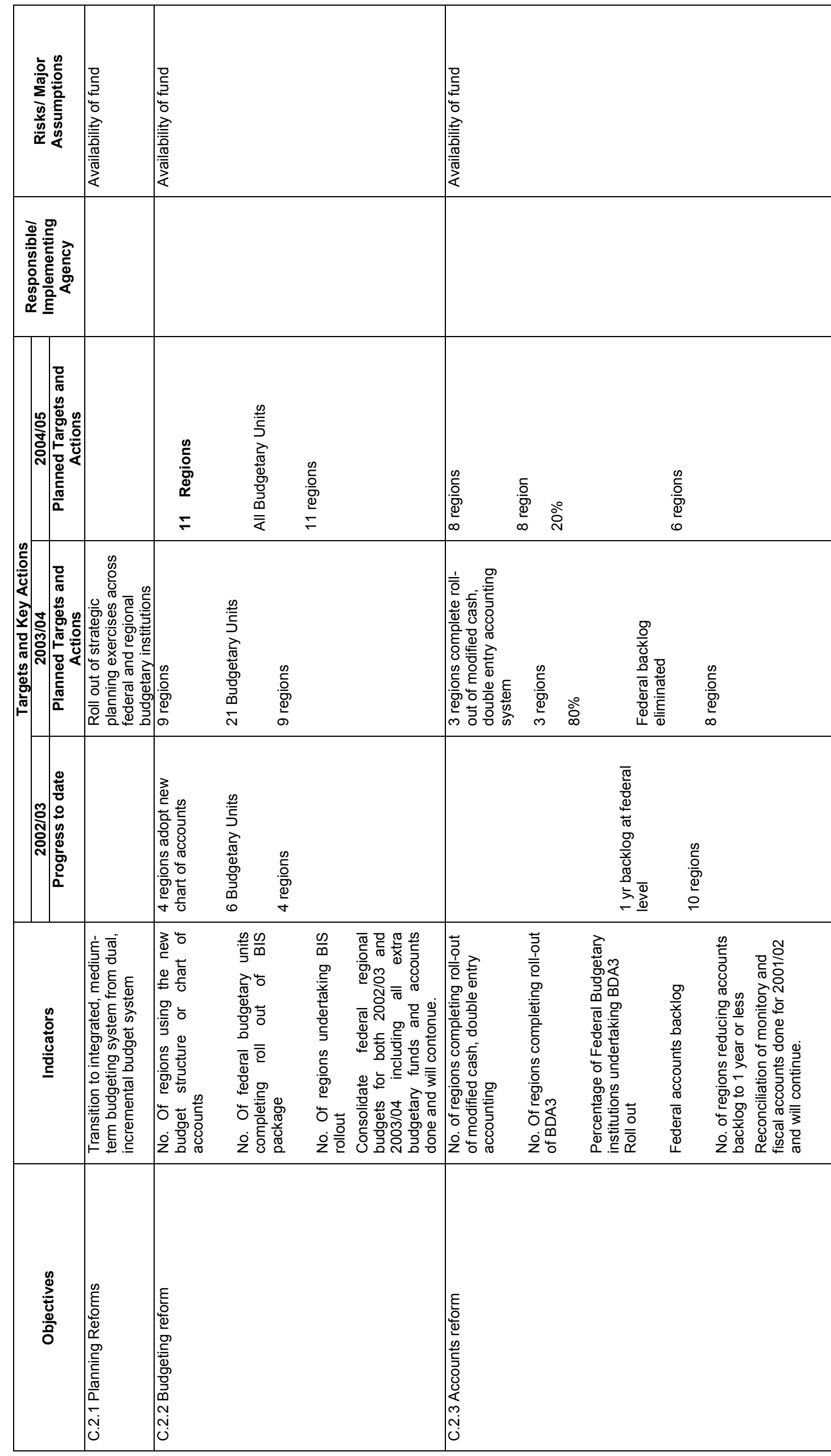

$\stackrel{?}{\leftarrow}$

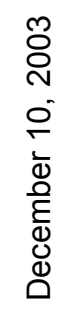




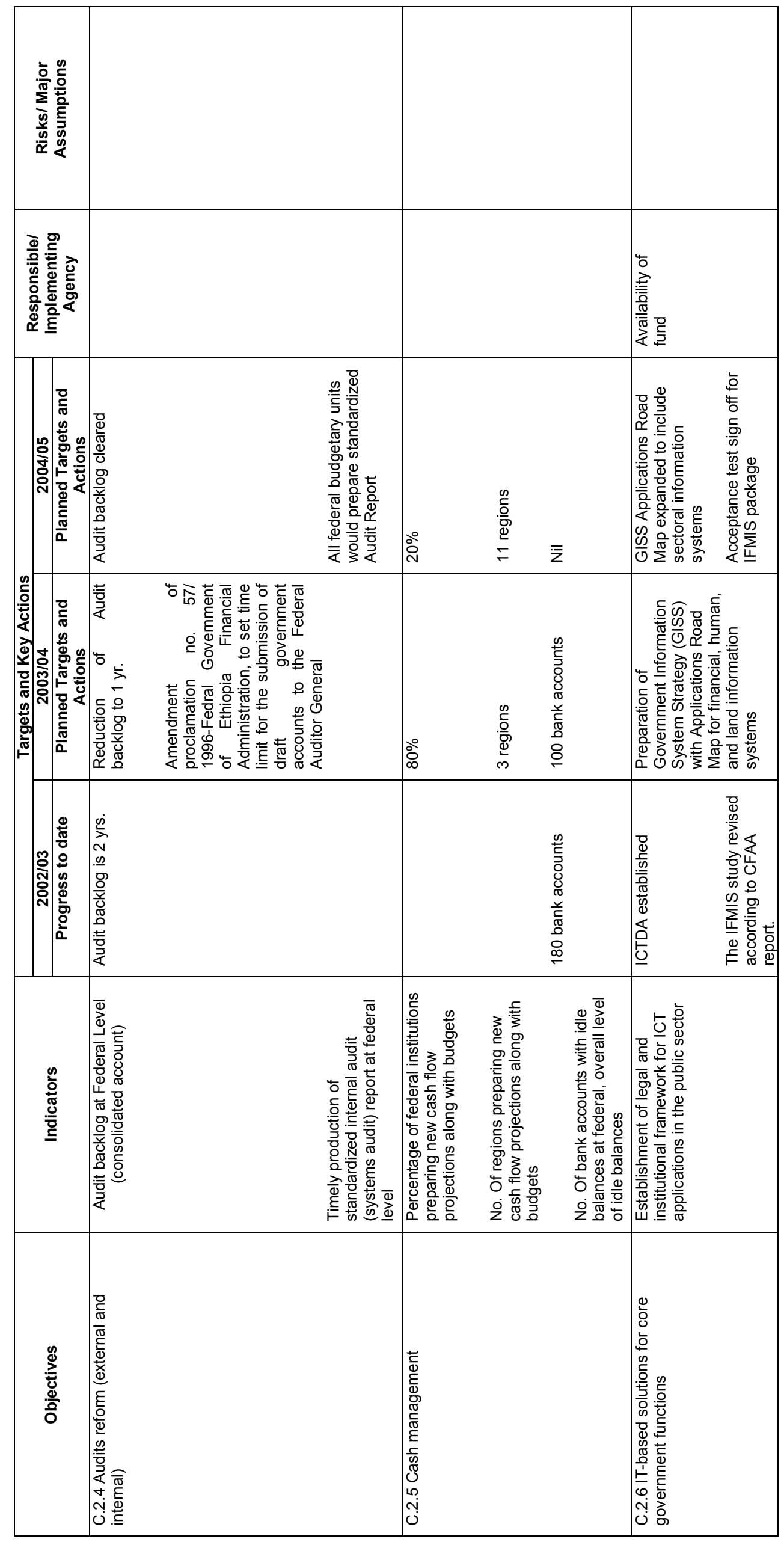




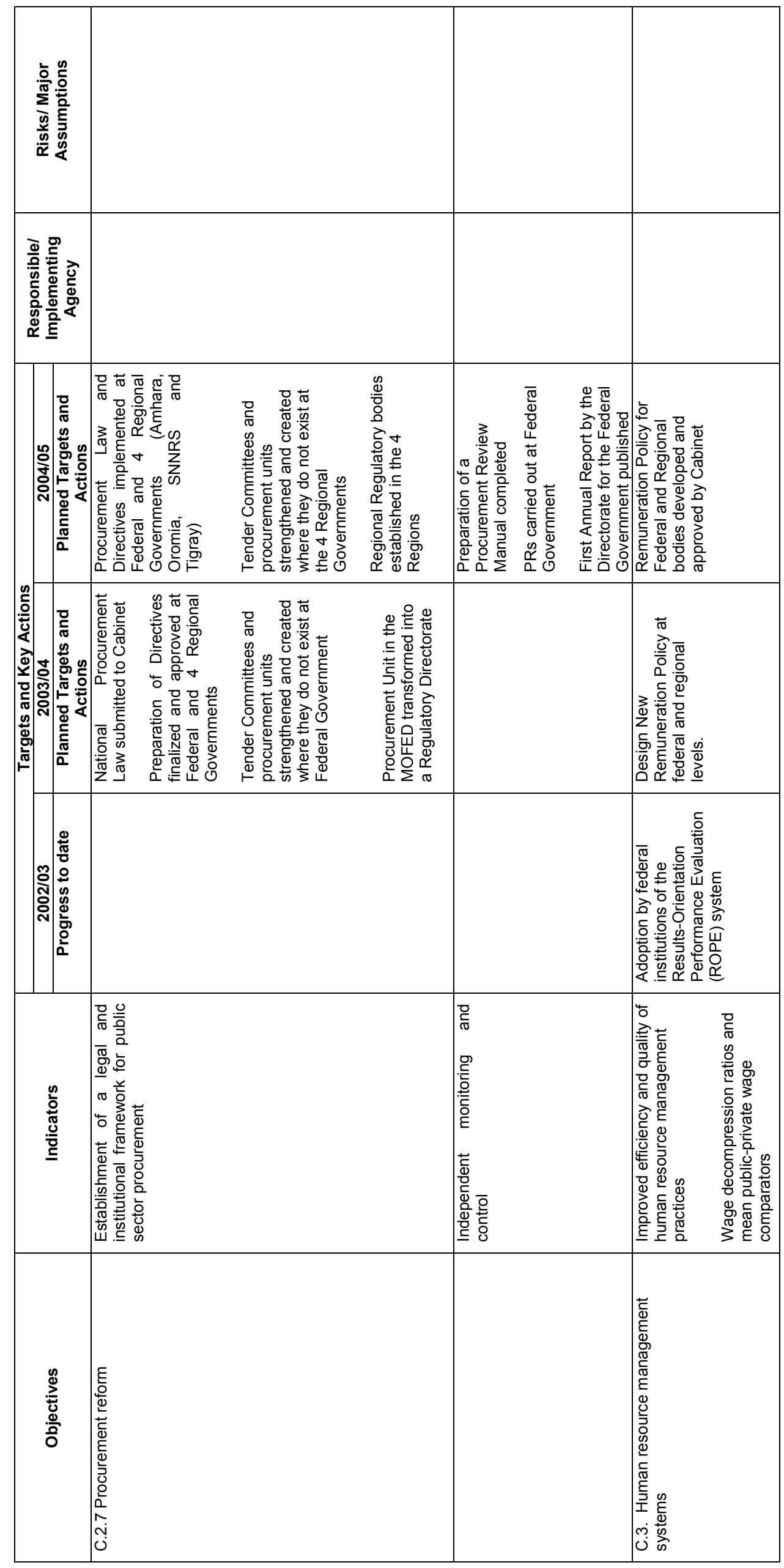




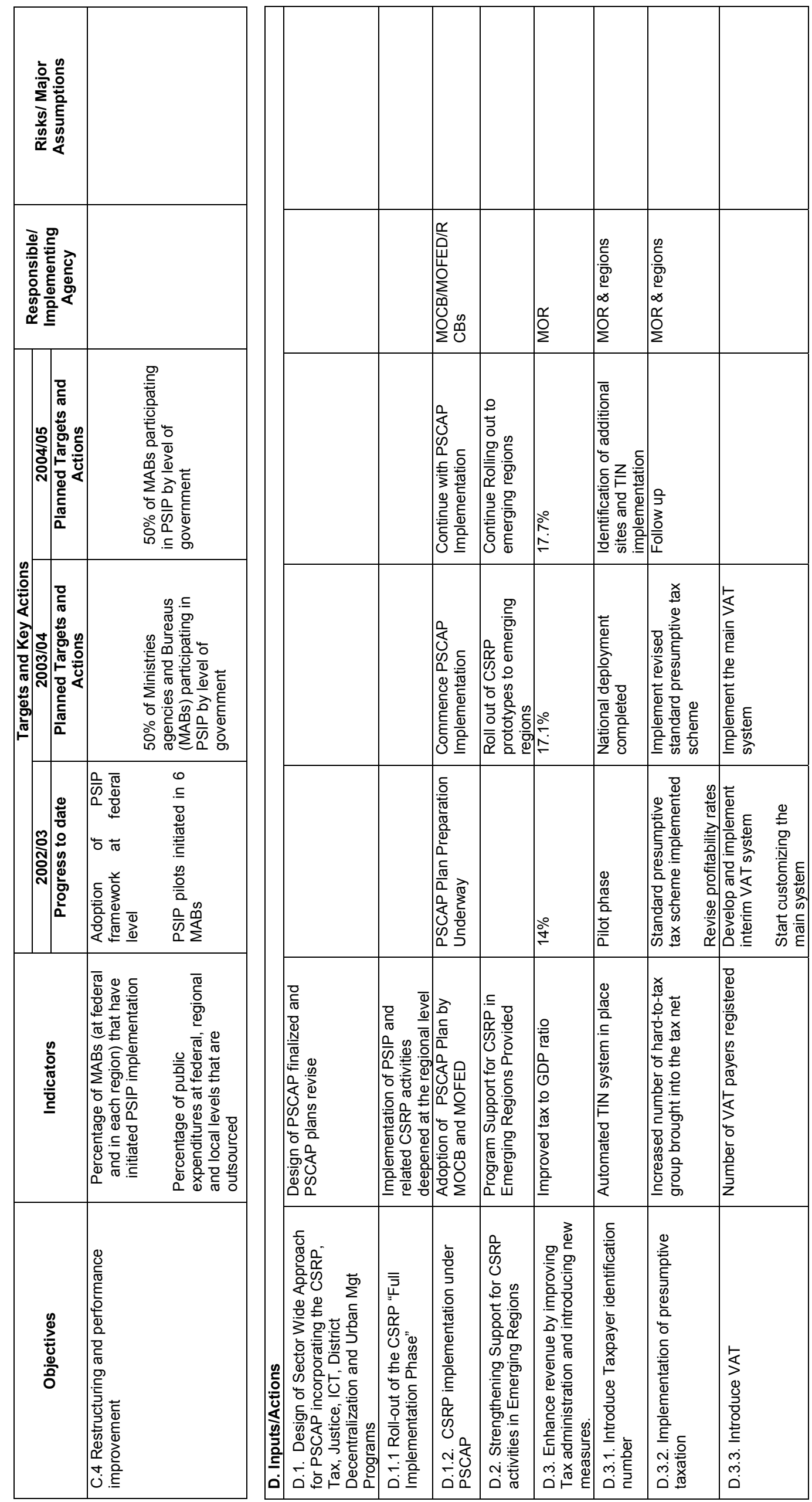

证

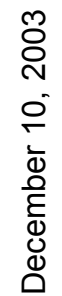




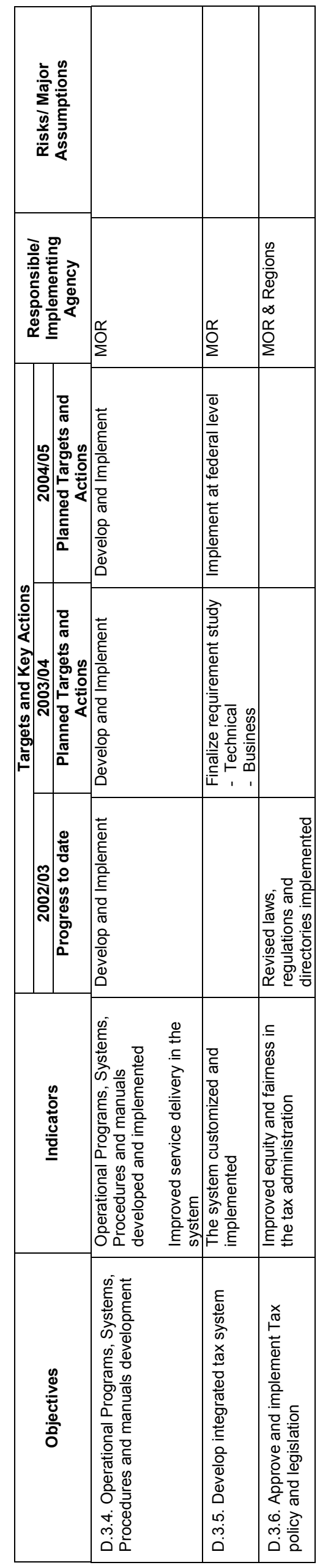

立

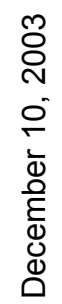


ANNEX TABLE2: LIST OF URBAN CENTERS SELECTED FOR URBAN

MANAGEMENT REFORM PROGRAM

IN FOUR MAJOR REGIONS

\begin{tabular}{|l|l|l|l|l|}
\hline No. & \multicolumn{1}{|c|}{ Amhara } & \multicolumn{1}{c|}{ Tigray } & \multicolumn{1}{c|}{ Oromia } & \multicolumn{1}{c|}{ SNNPR } \\
\hline 1 & Bahir Dar & Mekelle & Adama & Awassa \\
\hline 2 & Gonder & Adigrat & Bishoftu & Arbaminch \\
\hline 3 & Dessie & Axum & Jimma & Sodo \\
\hline 4 & Kombolcha & Endessilassie & Shashemene & Dilla \\
\hline 5 & Weldia & Alamata & Chiro & Hosana \\
\hline 6 & Debreberhan & Adwa & Robe & Yirgalem \\
\hline 7 & Kemissie & Maychew & Yabello & Butagira \\
\hline 8 & Finoteselam & Korem & Negelle & Sewla \\
\hline 9 & Sekota & Wukro & Asela & Welkite \\
\hline 10 & Debretabor & Humera & Aweday & AlabaKulito \\
\hline 11 & Enjibara & Sheraro & Fiche & Boditi \\
\hline 12 & DebreMarko & Abiy Adi & Sebeta & Jinka \\
\hline 13 & s & & & \\
\hline 14 & & & Holeta & Areka \\
\hline 15 & & & Sendafa & Yirgachefe \\
\hline 16 & & & Gimbi & AletaWendo \\
\hline 17 & & & Metu & Bonga \\
\hline 18 & & & Ambo & Teppi \\
\hline 19 & & & Weliso & Durame \\
\hline 20 & & & Burayu & \\
\hline 21 & & & & \\
\hline
\end{tabular}




\section{Annex 3. List of Censuses and surveys conducted by the Central Statistical Authority} (1961- 2008)

\section{Annex Table 3.1: List of Censuses and Surveys Conducted by the CSA (1961- 2002)}

\begin{tabular}{|c|c|c|}
\hline & & Year.(G.C.) \\
\hline \multirow[t]{6}{*}{1} & $\mathrm{H} / \mathrm{H}$ income, Consumption and Expenditures Surveys & \\
\hline & a) Addis Ababa H/H Budget Survey & 1963 \\
\hline & b) Rural $\mathrm{H} / \mathrm{H}$ Expenditure and Consumption Survey & $1968 \& 1981$ \\
\hline & c) Addis Ababa $\mathrm{H} / \mathrm{H}$ Expenditure and Consumption Survey & 1968 \\
\hline & d) Urban $\mathrm{H} / \mathrm{H}$ Income, Consumption and Expenditure Survey & 1974 \\
\hline & e) $\mathrm{H} / \mathrm{H}$ Income, Consumption and Expenditure Survey & $1995 / 96,1999 / 2000$ \\
\hline \multirow[t]{10}{*}{2} & Sample Surveys and Census & \\
\hline & a) First Round National Sample Surveys & 1963 \\
\hline & b) Second Round National Sample Survey & 1968 \\
\hline & c) Addis Ababa Population and Housing Census & $1961 \& 1968$ \\
\hline & d) Asmara Population and Housing Census & 1968 \\
\hline & e) Addis Ababa Housing Registration and Demographic Survey & 1978 \\
\hline & f) Rural Demographic Survey and Agricultural Sample Survey & 1979 \\
\hline & g) Rural Demographic Survey & $1980 \& 1981$ \\
\hline & h) Rural Sample Vital Registration & 1983-1987, 1997-1999 \\
\hline & i) Demographic and Health Survey & 2000 \\
\hline \multirow[t]{3}{*}{3} & Agricultural Sample Survey & \\
\hline & a) Agricultural Sample Survey & $1981-1991 \& 1994-2001$ \\
\hline & b) Crop Production Forecasting Survey & $1981-1991 \& 1994-2002$ \\
\hline 4 & $\begin{array}{l}\text { National Fertilizer Bench-Mark Survey } \\
\text { Holdings of Meher and Belg Seasons) }\end{array}$ & 1997 \\
\hline 5 & $\begin{array}{l}\text { Agricultural Crop Livestock and Population Sample Census of } \\
\text { Harari Region }\end{array}$ & 1997 \\
\hline 6 & Enset Survey & $1979 \& 1980$ \\
\hline 7 & Addis Ababa $\mathrm{H} / \mathrm{H}$ Energy Consumption Survey & $1979 \& 1980$ \\
\hline 8 & Addis Ababa Economic Establishment's Census & 1984-1992 \\
\hline 9 & Rural Survey of Community Level Variables & 1981 \\
\hline 10 & Rural Health Survey & $1982 \& 1983$ \\
\hline 11 & Rural Nutrtion Survey & $1982 \& 1983$ \\
\hline 12 & Health and Nutrition Survey & 1998 \\
\hline 13 & Fertility Survey of Urban Addis Ababa & 1995 \\
\hline \multirow[t]{5}{*}{14} & Labor Force Surveys & \\
\hline & a) Addis Ababa Labor Force and Housing Survey & 1976 \\
\hline & b) Labor Force and Housing Survey in 17 Major Towns & 1978 \\
\hline & c) Rural Labor Force Survey & $1982-1987 / 88$ \\
\hline & d) National Labour Force Survey & 1999 \\
\hline \multirow[t]{4}{*}{15} & Population and Hosing Census ( I and II) & \\
\hline & a) Preparatory Activities Including Census Manpower & 1981-1984, 1992-1994 \\
\hline & b) Population and Housing Census Enumeration & 1984,1994 \\
\hline & c) Census data Prparation, Processing and Report Writing & 1984-1989, 1994-1999 \\
\hline 16 & $\begin{array}{l}\text { Base Line Socio-Economic and Demographic Study of Resettled } \\
\text { Population }\end{array}$ & 1984 \\
\hline
\end{tabular}

\footnotetext{
* Includes Area and production (main and Belg seasons), crop land utilization, Livestock and poultry and Agricultural practice (main and Belg seasons).
} 


\begin{tabular}{|l|l|l|}
\hline 17 & National Family and Fertility Survey & 1990 \\
\hline 18 & Rural Nutrition Survey (Core Module) & 1992 \\
\hline 19 & Welfare Monitoring Survey & $1995-1996,1999$ \\
\hline 20 & Survey of Disabled Population (Amhara, Oromia and SNNP) & 1996 \\
\hline 21 & Survey of Small Scale Industries & 1997 \\
\hline 22 & Survey of Cottage, Handicrafts & 1997 \\
\hline 23 & Survey of Distributive Trade & 1997 \\
\hline 24 & Informal Sector Survey & 1996 \\
\hline 25 & Survey of Contract Construction-Activities & $1995,1999,2000$ \\
\hline 26 & Survey of Mining and Quarrying (Pilot) & \\
\hline 27 & Regular Statistical Activities & $1963-2002$ \\
\hline & a) Survey of Manufacturing Industries & $1963-2001$ \\
\hline & b) Transport and communications Statistics & $1965-2001$ \\
\hline & c) Retail Price Survey for Addis Ababa & $1963-2001$ \\
\hline & d) Statistical Abstract of Ethiopia & $1974-2002$ \\
\hline & e) Retail Price Survey in Selected 23 urban Centers (monthly) & $1974-1991$ \\
\hline & f) Rural Producers and Retail Price Survey (Monthly) & $1996-2002$ \\
\hline & g) Consumers Price Indices & $1990-2000-2001$ \\
\hline & h) External Merchandise Trade & \\
\hline
\end{tabular}




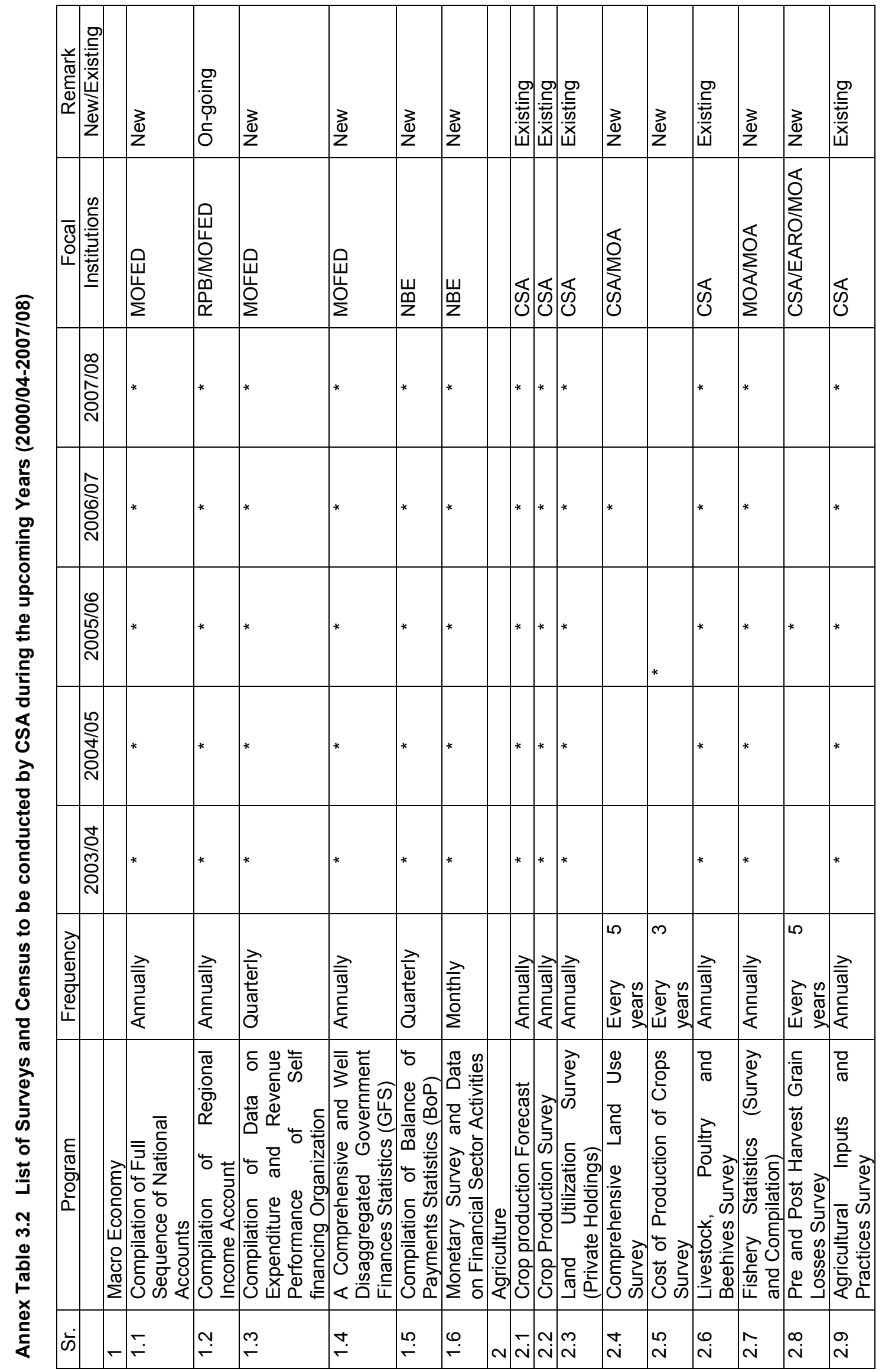

5

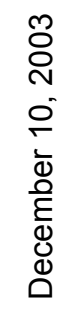




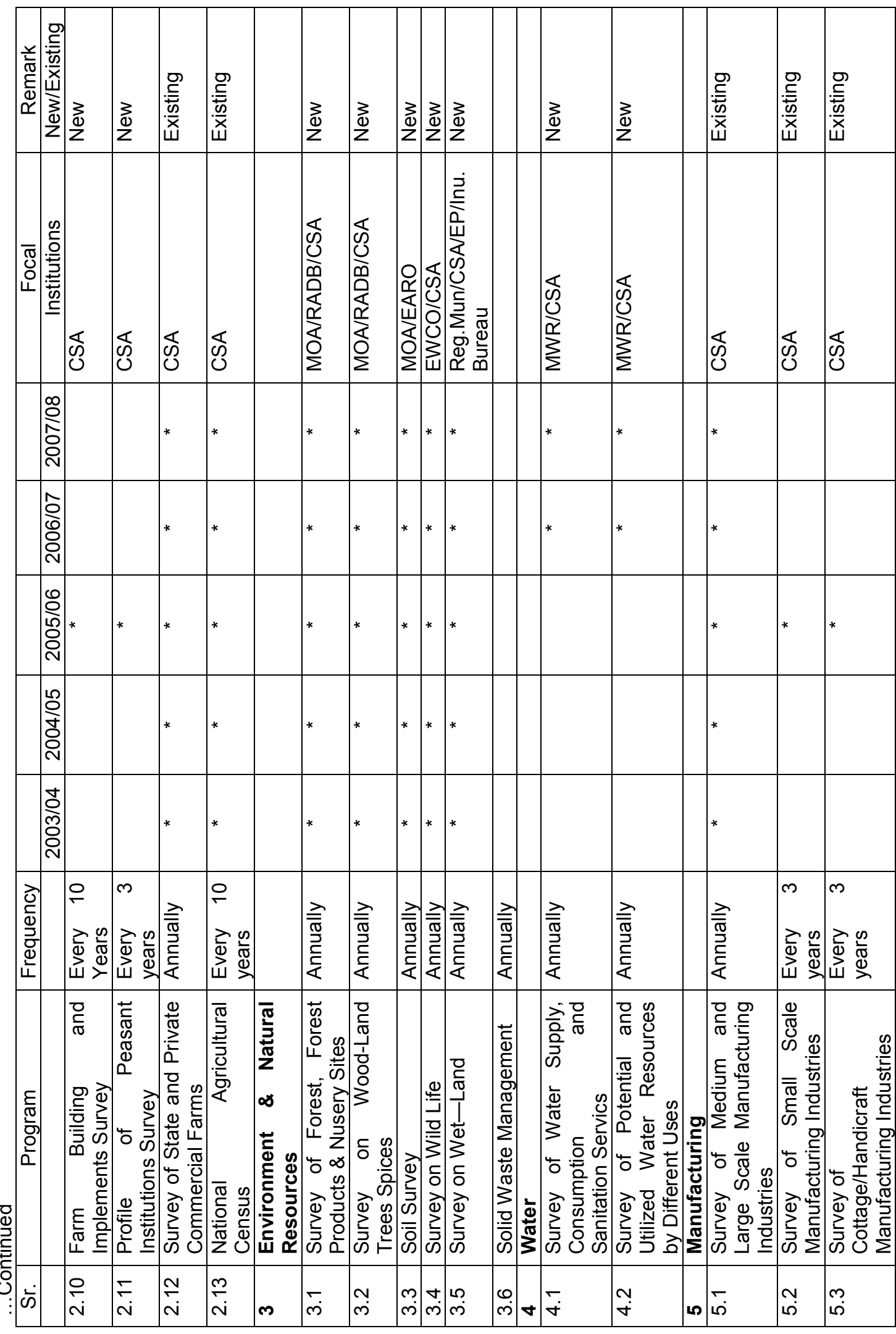

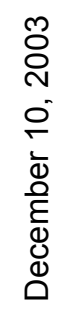



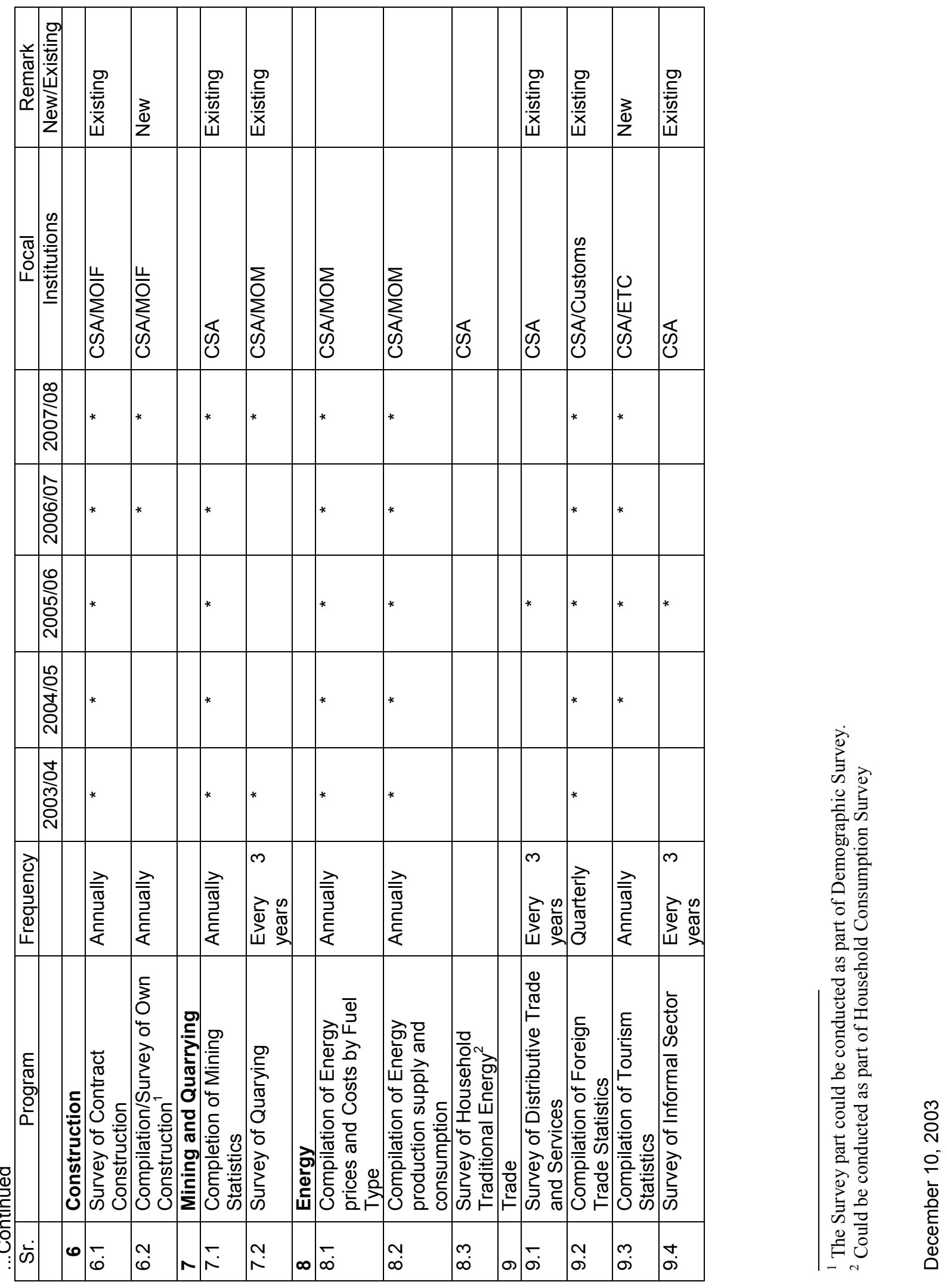


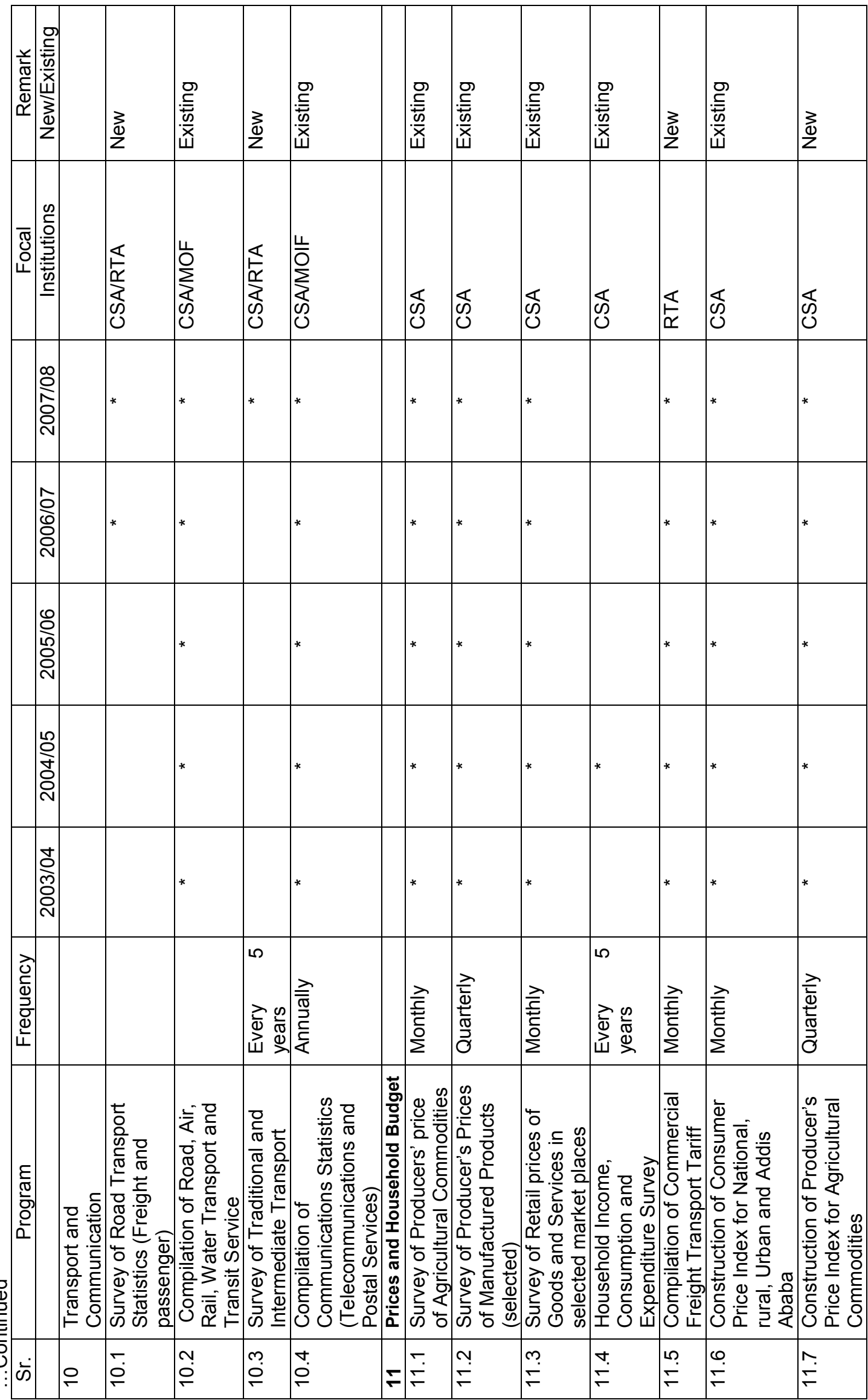

เ్ 


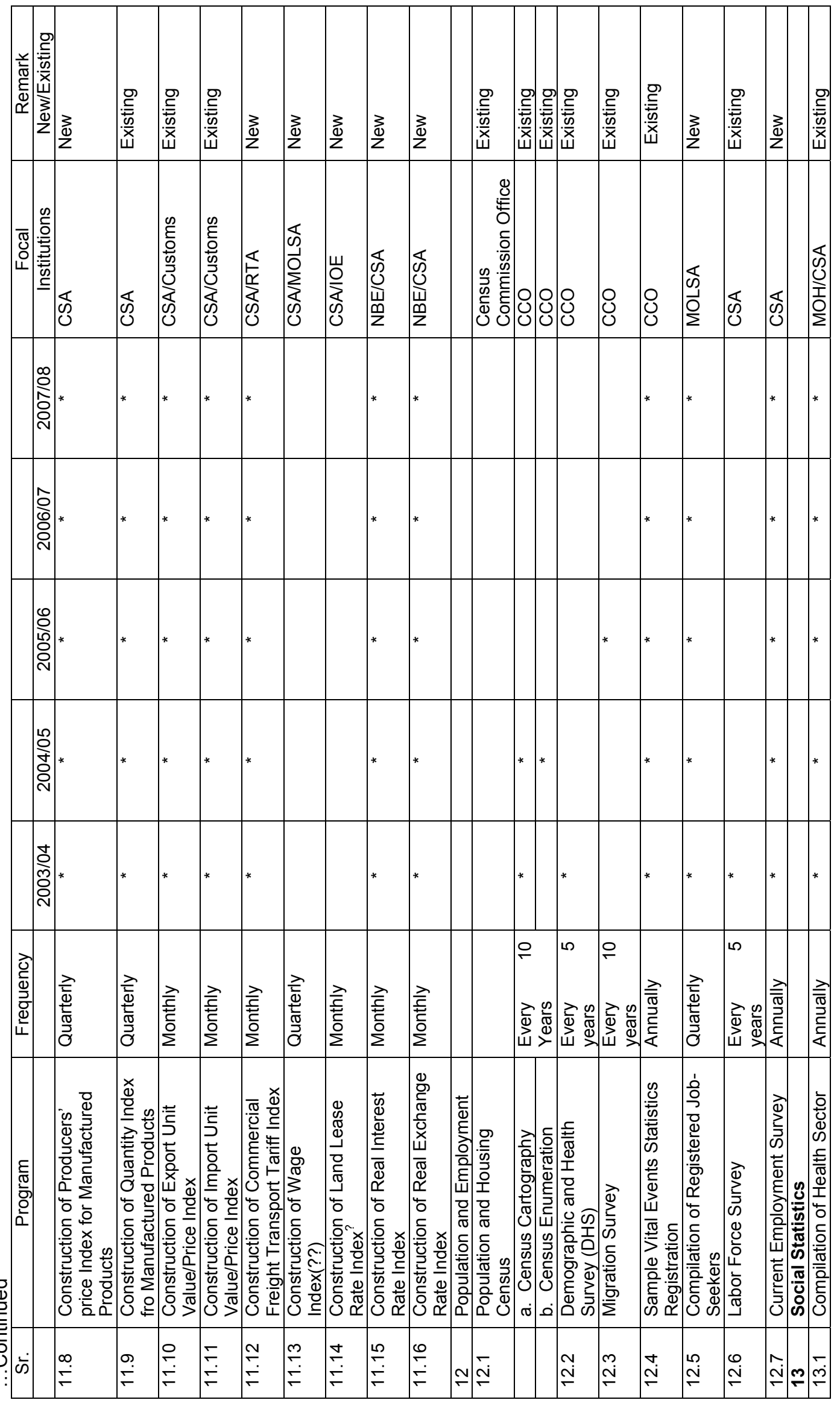

吕 


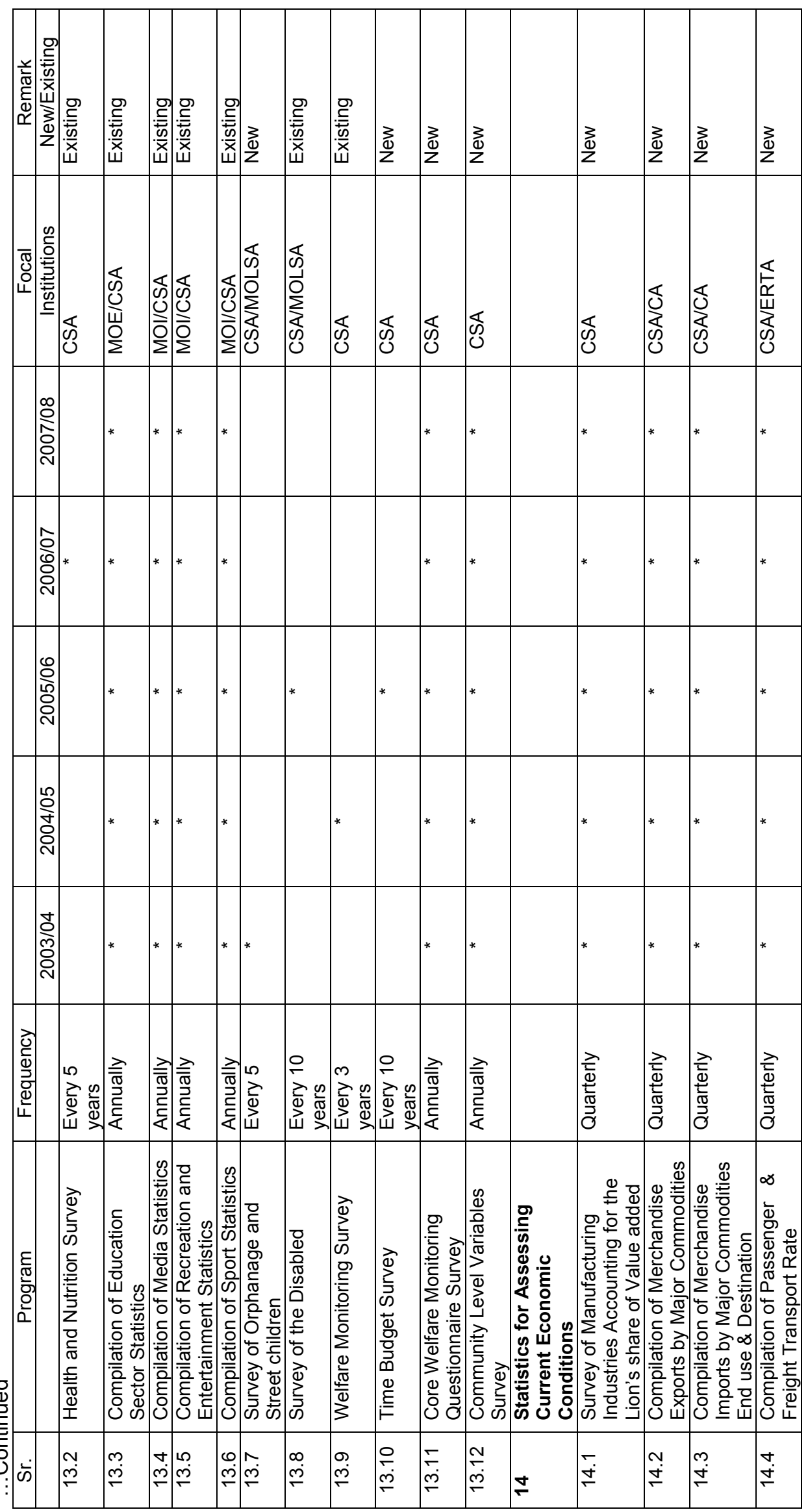

